\title{
ISSN 2411-7609
}

DOI: 10.17117/na.2015.05

https://ukonf.com/doc/na.2015.05.pdf

\section{Научный}

\section{альманах}

\section{$2015 \cdot N 5(7)$}

\section{Science almanac}
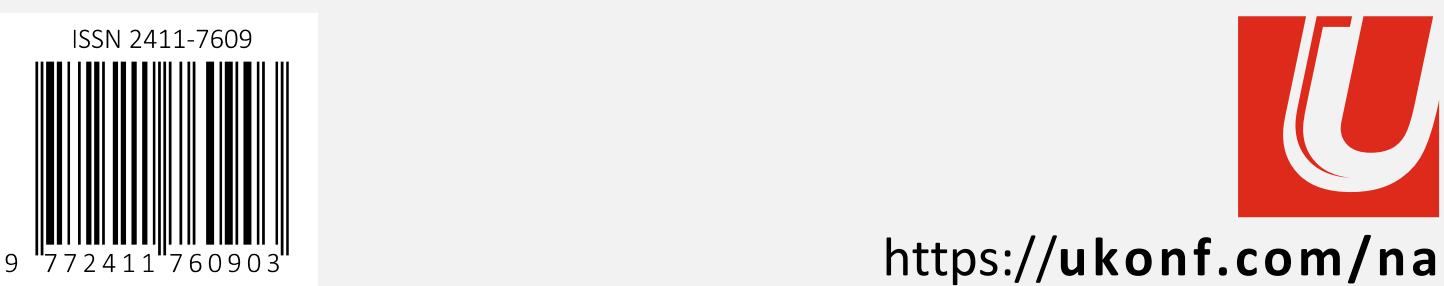

https://ukonf.com/na

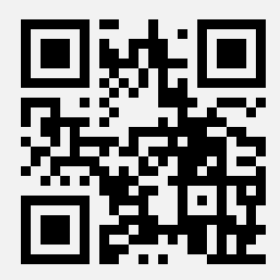




\section{DOI: $10.17117 /$ na.2015.05}

ISSN 2411-7609

\section{Научный альманах}

$2015 \cdot N$ 5(7)

Выходит 12 раз в год

Свидетельство о регистрации средства массовой информации ЭЛ № ФС 77-56326 от 02.12.2013 г. выдано Федеральной службой по надзору в сфере связи, информационных технологий и массовых коммуникаций (Роскомнадзор)

Учредитель и издатель:

ООО «Консалтинговая компания Юком»

Главный редактор: Уляхин Т.М.

Адрес редакции: Россия, 392000, г. Тамбов, а/я 44

URL: https://ukonf.com/na

E-mail:na@ukonf.com

Информация об опубликованных статьях

предоставляется в РИНЦ (договор № 255-04/2015)

\section{Science almanac}

$2015 \cdot \mathrm{N}$ 5(7)

Issued 12 times a year

Registration Certificate of mass

media EL № FS 77-56326 from 12/02/2013

given by Federal service of supervision in the scope of communication, information technologies and mass media (Roskomnadzor)

Founder and Publisher: Consulting company Ukom Editor in Chief: Ulyahin T.M.

Address of Publisher:

Russia, 392000, Tambov, PO box 44

URL: https://ukonf.com/na

E-mail:na@ukonf.com

The information about published articles is given to the RISQ system (contract № 255-04/2015)

Статьи, поступающие в редакцию, рецензируются. Материалы публикуются в авторской редакции. За содержание и достоверность статей ответственность несут авторы. не совпадать: на издание обязательна. Издание основано в 2013 году. Усл. печ. л. 15,44.

По материалам международной научно-практической конференции «Актуальные вопросы в научной работе и образовательной деятельности», Россия, г. Тамбов, 30 мая 2015 года.

\section{Редакционная коллегия}

Аксенова Светлана Владимировна

Доктор медицинских наук, профессор

Мордовский государственный университет им. Н.П. Огарёва

2. Саранск, ул. Ульянова, $26 \mathrm{~A}$

\section{Баширов Вадим Дипрович}

Доктор сельско-хозяйственных наук, профессор

Оренбургский государственный университет

2. Оренбург, пр. Победы, 13

\section{Гоциридзе Рауль Симонович}

Доктор химических наук, директор

Батумский государственный университет им. Шота Руставели

Грузия, г. Батуми, ул. Гришашвили 5

\section{Егорова Галина Ивановна}

Доктор педагогических наук, профессор, зав. кафедрой

Тюменский государственный нефтегазовый университет

(филиал)

2. Тобольск, Зона Вузов, 9

\section{Зайнуллина Лилия Маратовна}

Доктор филологических наук, профессор, зав. кафедрой

Башкирский государственный университет

2. Уфа, ул. К. Маркса, 3/4

\section{Кожин Владимир Александрович}

Доктор экономических наук, профессор, зав. кафедрой

Нижегородский институт менеджмента и бизнеса

г. Нижний Новгород, ул. Горная, 13

\section{Коротков Владислав Георгиевич}

Доктор технических наук, профессор, декан

Оренбургский государственный университет

2. Оренбург, пр. Победы, 13

\section{Editorial board}

Aksenova Svetlana Vladimirovna

Candidate of Medical Sciences, Professor

Mordovia State University named N.P. Ogarev

Saransk, Ulyanov st., 26 A

Bashirov Vadim Diprovich

Doctor of Agricultural Sciences, Professor

Orenburg State University

Orenburg, Pobedy ave., 13

Gotsiridze Raul Simonovich

Doctor of Chemical Sciences, Director

Batumi State University named Shota Rustaveli

Georgia, Batumi, Grishashvili st., 5

\section{Egorova Galina Ivanovna}

Doctor of Pedagogical Sciences, Professor, head of Department

Tyumen State Oil and Gas University (branch)

Tobolsk, Zona Vuzov, 9

\section{Zaynullina Liliya Maratovna}

Doctor of Philological Sciences, Professor, head of Department Bashkir State University

Ufa, K. Marks st., 3/4

\section{Kozhin Vladimir Aleksandrovich}

Doctor of Economics Science, Professor, head of Department Nizhny Novgorod Institute of Management and Business

Nizhny Novgorod, Mountain st., 13

Korotkov Vladislav Georgievich

Doctor of Engineering Sciences, Professor, Dean

Orenburg State University

Orenburg, Pobedy ave., 13 


\section{Редакционная коллегия}

\section{Марченко Марина Николаевна}

Доктор педагогических наук, профессор, зав. кафедрой

Кубанский государственный университет

г. Краснодар, ул. Ставропольская, 149

\section{Мегрелишвили Зураб Неврович}

Доктор технических наук, профессор,

руководитель департамента

Батумский государственный университет им. Ш. Руставели Грузия, Батуми, ул. Пиросмани, 12

\section{Пирожков Геннадий Петрович}

Доктор культурологии, профессор

Тамбовский государственный технический университет

г. Тамбов, ул. Советская, 106

\section{Попова Ангелина Алексеевна}

Доктор химических наук, доцент, зав. кафедрой

Майкопский государственный технологический университет

2. Майкоп, ул. Первомайская, 191

\section{Прохоров Владимир Тимофеевич}

Доктор технических наук, профессор, зав. кафедрой

Институт сферы обслуживания и предпринимательства

(филиал) ДГТУ

2. Шахты, ул. Шевченко, 147

\section{Авдеева Надежда Александровна}

Кандидат медицинских наук, профессор

Мордовский государственный университет им. Н.П. Огарёва

2. Саранск, ул. Ульянова, 26 А

\section{Дружинина Анна Валентиновна}

Кандидат юридических наук, доцент, проректор

Международный инновационный университет

2. Сочи, ул. Орджоникидзе, $10 \mathrm{~A}$

\section{Зёлко Александра Сергеевна}

Кандидат педагогических наук, доцент

Балтийский федеральный университет им. И. Канта

г. Калининград, ул. А. Невского, 14

\section{Иремадзе Элисо Отаровна}

Кандидат химических наук, доцент

Башкирский государственный университет (филиал)

2. Стерлитамак, пр. Ленина, $49 \mathrm{~A}$

\section{Казакова Светлана Юрьевна}

Кандидат философских наук, доцент

Южный федеральный университет

2. Ростов на Дону, ул. Б. Садовая, 105/42

\section{Кленина Елена Анатольевна}

Кандидат философских наук, доцент

Волгоградский государственный технический университет

2. Волгоград, пр. им. Ленина, 28

\section{Коновалов Алексей Петрович}

Кандидат исторических наук, профессор, Заслуженный деятель науки, Почетный работник образования Республики Казахстан Государственный университет им. Шакарима

Казахстан, г. Семей, ул. Глинки, $20 \mathrm{~A}$

\section{Кузнецов Евгений Геннадьевич}

Кандидат педагогических наук, доцент

Калининградский государственный технический университет

г. Калининград, ул. Молодежная, 6

\section{Курджиев Магомед Таубиевич}

Доцент, каф. Педагогики и психологии

Карачаево-Черкесский государственный университет

им У.Д. Алиева

г. Карачаевск, ул. Ленина, 29

\section{Editorial board}

Marchenko Marina Nikolaevna

Doctor of Pedagogical Sciences, Professor, head of Department Kuban State University

Krasnodar, Stavropolskaya st., 149

Megrelishvili Zurab Nevrovich

Doctor of Technical Science, Professor, head of Department Batumi State University named Sh. Rustaveli

Georgia, Batumi, Pirosmani st., 12

Pirozhkov Gennadiy Petrovich

Doctor of Culturology, Professor

Tambov State Technical University

Tambov, Sovetskaya st., 106

Popova Angelina Alekseevna

Doctor of of Chemical Sciences, associate Professor,

head of Department

Maykop State Technological University

Maykop, Pervomayskaya st., 191

\section{Prokhorov Vladimir Timofeevich}

Doctor of Technical Sciences, Professor, head of Department Institute of the Service Sector and Entrepreneurship (branch) DSTU

Shakhty, Shevchenko st., 147

\section{Avdeeva Nadezhda Aleksandrovna}

Candidate of Medical Sciences, Professor

Mordovia State University named N.P. Ogarev

Saransk, Ulyanov st., 26 A

\section{Druzhinina Anna Valentinovna}

Candidate of Juridical Sciences, associate Professor, Vice Rector International Innovative University

Sochi, Ordzhonikidze st., $10 \mathrm{~A}$

\section{Zelko Alexandra Sergeevna}

Candidate of Pedagogical Sciences, associate Professor

Baltic Federal University named Kant

Kaliningrad, A. Nevsky st., 14

\section{Iremadze Eliso Otarovna}

Candidate of Chemical Sciences, associate Professor

Bashkir State University (branch)

Sterlitamak, Lenin ave., $49 \mathrm{~A}$

\section{Kazakova Svetlana Yurievna}

Candidate of Philosophical Sciences, associate Professor

Southern Federal University

Rostov-on-Don,. B. Sadovaya st., 105/42

\section{Klenina Elena Anatolievna}

Candidate of Philosophy Science, associate Professor

Volgograd State Technical University

Volgograd, Lenin ave., 28

\section{Konovalov Aleksey Petrovich}

Candidate of Historical Sciences, Professor

State University named Shakarim

Kazakhstan, Semey, Glinky st., 20 A

\section{Kuznetsov Evgeniy Gennadyevich}

Candidate of Pedagogical Sciences, associate Professor Kaliningrad State Technical University

Kaliningrad, Molodegnaya st., 6

\section{Magomed Taubievich Kurdzhiev}

Associate Professor, dept. Pedagogy and Psychology Karachay-Cherkessian State University named U.D. Aliyev Karachaevsk, Lenin st., 29 


\section{Редакционная коллегия}

\section{Левин Евгений Владимирович}

Кандидат физико-математических наук, генеральный директор Научно-исследовательский и проектный институт

экологических проблем

г. Оренбург, ул. Караванная, 6 A

\section{Песков Аркадий Евгеньевич}

Кандидат политических наук, доцент

Волгоградский государственный архитектурно-строительный университет

2. Волгоград, ул. Академическая, 1

\section{Петровых Ирина Николаевна}

Кандидат энциклопедических наук, зав. отделом

Южно-Уральский государственный университет

2. Челябинск, ул. Артиллерийская, 100

\section{Полуянова Нина Васильевна}

Кандидат педагогических наук, зам. директора,

Заслуженный учитель РФ

Гимназия им. Н.Д. Лицмана

2. Тобольск, 7 мкрн, 54

\section{Сабирова Венера Кубатовна}

Кандидат филологических наук, доцент

Российский государственный социальный университет

(филиал)

Киргизия, г. Ош, ул. Карасуйская, 161

\section{Савинова Людмила Юрьевна}

Кандидат педагогических наук, доцент

Российский государственный педагогический университет

им. А.И. Герцена

2. Санкт-Петербург, наб. реки Мойки, 48

\section{Сагитов Рамиль Фаргатович}

Кандидат технических наук, доцент, начальник отдела

Научно-исследовательский и проектный институт

экологических проблем

2. Оренбург, ул. Караванная, 6 A

\section{Смирнов Виктор Владимирович}

Кандидат технических наук, доцент

Тверской государственный технический университет

2. Тверь, наб. А. Никитина, 22

\section{Суханова Майя Викторовна}

Кандидат технических наук, доцент

Донской государственный аграрный университет

2. Зерноград, ул. им. Ленина, 21

\section{тюрин Александр Николаевич}

Кандидат географических наук, доцент

Оренбургский государственный педагогический университет

2. Оренбург, ул. Советская, 19

\section{Хоронеко Светлана Евгеньевна}

Кандидат биологических наук, доцент

Мордовский государственный университет им. Н.П. Огарёва

2. Саранск, ул. Ульянова, $26 \mathrm{~A}$

\section{Шамрова Елена Александровна}

Кандидат медицинских наук, доцент

Мордовский государственный университет им. Н.П. Огарёва

2. Саранск, ул. Ульянова, 26 A

\section{Editorial board}

Levin Evgeny Vladimirovich

Candidate of Physical and Mathematical Sciences, general Director

Scientific Research and Design Institute of Ecological Problems Orenburg, Caravannaya st., $6 \mathrm{~A}$

Peskov Arkadiy Evgenievich

Candidate of Political Sciences, associate Professor

Volgograd State University of Architecture and Civil

Engineering

Volgograd, Akademicheskaya st., 1

\section{Petrovykh Irina Nikolayevna}

Candidate of Encyclopedic Sciences, head of Department South Ural State University

Chelyabinsk, Artilleriyskaya st., 100

\section{Poluyanova Nina Vasilyevna}

Candidate of Pedagogic Sciences, deputy Director

Gymnasium named N.D. Litsman

Tobolsk, 7th distr., 54

\section{Sabirova Venera Kubatovna}

Candidate of Philological Sciences, Professor, Associate Professor

Russian State Social University (branch)

Kyrgyzstan, Osh, Karasuyskaya st., 161

Savinova Lyudmila Yurievna

Candidate of Pedagogical Sciences, associate Professor Russian State Pedagogical University named A.I. Herzen St. Petersburg, Moika emb., 48

\section{Sagitov Ramil Fargatovich}

Candidate of Technical Sciences, associate Professor, head of Department

Research and Design Institute of Ecological Problems Orenburg, Caravannaya st., $6 \mathrm{~A}$

\section{Smirnov Viktor Vladimirovich}

Candidate of Technical Scienses, associate Professor

Tver State Technical University

Tver, A. Nikitin emb., 22

\section{Sukhanova Maya Viktorovna}

Candidate of Technical Sciences, associate Professor

Don State Agrarian University

Zernograd, Lenin st., 21

\section{Tyurin Alexander Nikolaevich}

Candidate of Geographical Sciences, associate Professor Orenburg State Pedagogical University

Orenburg, Sovetskaya st., 19

\section{Horoneko Svetlana Evgenievna}

Candidate of Medical Sciences, associate Professor Ogarev Mordovia State University

Saransk, Ulyanov st., 26 A

\section{Shamrova Elena Aleksandrovna}

Candidate of Medical Sciences, associate Professor Mordovia State University named N.P. Ogarev

Saransk, Ulyanov st., 26 A 


\section{Содержание}

\section{ЭКОНОМИЧЕСКИЕ НАУКИ}

Гаврилкова Н.Ю.

Экономическая эффективность производства в зерновой отрасли

Денисова Н.И.

Современный механизм оказание консультационных услуг в сфере АПК

Дюженкова Н.В., Комбаров В.А.

Современное состояние рынка телекоммуникационных услуг в России.

Жердева И.В., Симоненко Н.Н.

Принципы разработки и принятия решений по стратегии бизнеса

Лабусов М.В.

Безработица как социальное явление и социальный процесс.

Радько О.Ю.

Автоматизация бизнес-процессов в общей системе управления финансово-

кредитным предприятием

Силантьева М.К.

Порто-франко, как инструмент развития рыбной промышленности Приморского края.

Сорина Е.И.

Электронная система документооборота - E-invoicing

ПЕДАГОГИЧЕСКИЕ НАУКИ

Абдуллина Л.Б., Головнева Е.В.

Опыт, проблемы и перспективы профессиональной подготовки современного

учителя начальной школы.

Головнева Е.В.

Народность как основной принцип национального воспитания в педагогическом творчестве К.Д. Ушинского

Голубина О.А., Кочнев А.В.

Особенности развития силовых качеств у девочек 13-14 лет занимающихся волейболом

Дерябина Н.В., Лазарева Т.М.

Компьютерное тестирование как одно из средств повышения эффективности

обучения в техническом вузе

Елманова И.В.

Вопросы формирования коммуникативных компетенций у студентов СПО

Ем Ю.М.

Опыт реализации программы профильного образования в ходе подготовки

квалифицированных кадров для проекта ЗАО «ВНХК»

Есимбекова А.О.

Проблемы полиязычия

Завьялова С.В., Завьялова А.А.

Применение ИКТ в музейно-экскурсионной деятельности 
Любимова А.С.

Влияние фармакологических средств на восстановление работоспособности студентов, занимающихся силовым фитнесом и пауэрлифтингом

Мамаева Н.А., Тривер Т.А., Черникова Н.А.

Некоторые аспекты использования кейс-метода в учебном процессе 96

Хоружев А.Г.

Оценка силовых критериев в системе физической функциональной

подготовленности

Ширина Т.Г.

Современные тенденции развития высшего образования: от европейского

к международному измерению

Ширин Д.А.

Интернет-маркетинг как современный инструмент обеспечения взаимодействия субъектов образовательного процесса.

ТЕХНИЧЕСКИЕ НАУКИ

Барсков В.В., Забелин Б.Ф.

К вопросу повышения конкурентоспособности и технологичности малорасходных газотурбогенераторов на этапе проектирования

Вицентий А.В., Шишаев М.Г.

К вопросу о разработке когнитивных интерфейсов для систем информационной поддержки управления развитием пространственно-распределенных систем

Дикарева Е.А., Сдобнова Л.Д., Сергеева А.А.

Техническое оснащение города для развития велодвижения в г. Волгограде

Капитонов С.С., Капитонова А.В.

Исследование зависимости прямого напряжения светодиода от температуры.

Струлева И.А., Крутько К.Н.

О взаимосвязи плотности и прочности экструзионного пенополистирола

МЕДИЦИНСКИЕ НАУКИ

Красноруцкая О.Н., Бугримов Д.Ю., Савельева Ю.Е.

Динамика критериев оценки заболеваемости ОРВИ у дошкольников на фоне

применения иммуномодулирующей терапии

ХИМИЧЕСКИЕ НАУКИ

Гущина Е.А., Вдовичева В.В., Тихомиров Г.А.

О трисахаридах с точки зрения химика.

Киреева И.Ю.

Особенности мониторинга биоразнообразия водных экосистем.

Ягафарова Г.А., Кужина Г.Ш.

Содержание марганца в почвах д. Кирдасово Абзелиловского района Республики

Башкортостан

Дарбинян А.А., Дорофеева В.П., Копылович М.В., Мельникова С.Л., Токарева И.Е.

Клинический случай заворота желудка у собаки 
Дорофеева В.П., Копылович М.В., Мельникова С.Л.

Ожирение у собак: факторы риска, диагностика и диетотерапия 175

Лаврентьев Б.Ф.

Повышение рентабельности пчеловодства в России за счет создания

специализированных приборов.

Ховалыг Р.Б.

Животноводство - приоритетное направление в сельском хозяйстве региона 185

НАУКИ О ЗЕМЛЕ

Шишлова М.А., Ханкова С.А.

Детергенты в речных водах г. Уссурийска (Приморский край)

СОЦИОЛОГИЧЕСКИЕ НАУКИ

Гуляева В.Н., Евтихиева А.Н., Наумов А.И., Рябикова Л.А., Золотова Т.В., Федоров А.С.

Образование и перспективы развития образовательной системы XXI века

Титова А.А.

Социологический анализ экономического поведения населения России

ПСИХОЛОГИЧЕСКИЕ НАУКИ

Ивлев В.Ю.

Особенности нашей памяти

ФИЛОЛОГИЧЕСКИЕ НАУКИ

Воронин В.С.

Суггестия, контрсуггестия и законы фантазии в прозе А.П. Чехова 230

Голубева Ю.В.

Номинация жестов английскими глаголами и глагольными сочетаниями, не обладающими системным значением жестикуляции

Ласкова М.В., Статова И.Ф.

Особенности использования личного местоимения «Я» в английском и русском

языках.

ФИЛОСОФСКИЕ НАУКИ

Голубева С.Л.

Альтернативные системы интернет-коммуникаций

кУльтУрология

Савельева Д.А., Герасимова А.И, Ярмухаметов И.В.

Культурная идентичность. Эмпатия и симпатия как призма восприятия родной и чужой культуры...... 


\section{Contents}

Gavrilkova N.Yu.

Economic efficiency of production in the grain industry.

Denisova N.I.

The modern mechanism of rendering consulting services in the agrarian and industrial complex sphere

Dyuzhenkova N.V., Kombarov V.A.

The modern state of the market of telecommunication services in Russia

Zherdeva I.V., Simonenko N.N.

Principles for the development of financial business strategy.

Labusov M.V.

Unemployment as a social phenomenon and a social process.

Radko O.Yu.

Automatization of business processes in the generall management system of financial and credit organization .

Silantieva M.K.

Porto Franco - instrument of development fishing industry of Primorye.

Sorina E.I.

Electronic document management system - E-invoicing.

Golovneva E.V., Abdullina L.B.

Experience, problems and prospects vocational training of the modern elementary school teacher...

Golovneva E.V.

Nationality as the basic principle of national education in pedagogical creativity of K.D.

Ushinsky

Golubina O.A., Kochnev A.V.

Features of development of power qualities among 13-14 years old girl volleyball players

Deryabina N.V., Lasareva T.M.

Computer testing as one of the means of increasing the efficiency of learning process at a technical institute.

Elmanova I.V.

The problems of communicative competence formation in students of vocational education

Em Yu.M.

Experience of implementation of the profile education program during preparation of qualified personnel for the project of JSC VNHK

Yessimbekova A.O.

Problems of multilinguism

Zavyalova S.V., Zavyalova A.A.

The use of ICT in the Museum and tour activities

Liubimova A.S.

The influence of pharmacological agents on the recovery of the students involved in strength training fitness and powerlifting.

Mamaeva N.A., Chernikova N.A., Triver T.A.

Some aspects of using of case-method in the learning process 
Horuzhev A.G.

Evaluation criteria in the power system of physical functional training

Shirina T.G.

Current trends of higher education development: from European to international

dimension

Shirin D.A.

Internet-marketing as contemporary instrument that provides cooperation of subjects of educational process"

Barskov V.V, Zabelin B.F.

The issue of increasing the competitiveness and adaptability of economical gas turbo

generators at the design stage.

Vicentiy A.V., Shishaev M.G.

To the question of the cognitive interfaces development for information management support systems of the spatially distributed systems development

Dikareva E.A., Sdobnova L.D., Sergeeva A.A.

City hardware for development of the cycle movement in Volgograd

Kapitonov S.S., Kapitonova A.V.

Research of temperature dependence of forward voltage of LED

Struleva I.A., Krutko K.N.

About interrelation of density and durability of extrusive expanded polystyrene.

Krasnorutckaja O.N, Bugrimov D.Yu., Savelyeva Yu.E.

Dynamics of criteria for assessing the incidence of SARS in preschool children during

treatment with immunomodulatory therapy

Guschina E.A., Vdovicheva V.V., Tihomirov G.A.

About the trisaharidakh from the point of view of the chemist.

Kirieieva I.Yu.

The monitoring features of aquatic biodiversity.

Yagafarova G.A., Gugina G.Sh.

Manganese content in the ground was carried out in the Republic of Bashkortostan, in the

village of Abzelilovsky region

Darbinyan A.A., Dorofeeva V.P., Kopilovich M.V., Melnikova S.L., Tokareva I.E.

Clinical case of twisting of the stomach in dogs.

Dorofeeva V.P., Kopilovich M.V., Melnikova S.L.

Obesity in dogs: risk factors, diagnosis and diet therapy

Lavrentev B.F.

Increased profitability of beekeeping in Russia by creating specialized units

Khovalyg R.B.

Livestock - priority to agriculture in the region

Shishlova M.A., Hankova S.A.

Detergents in river waters of Ussuriisk (Primorsky Krai)

Gouliaeva V.N., Evtikhieva A.N., Ryabikova L.A., Naumov A.I., Zolotova T.V., Fedorov A.S.

Education and prospects of development of educational systems of the XXI century

Titova A.A.

Sociological analysis of economic behavior of the population of Russia .

Ivlev V.Yu.

Features of our memory. 
Voronin V.S.

Suggestion, kontrsuggestion and laws of fantasy A.P. Chekhov`s prose..

Golubeva Ju.V.

Nomination of gestures by English verbs and the verbal combinations of different lexical

categories.

Laskova M.V., Statova I.F.

The pecularities of personal pronoun „I“ usage in the English and Russian languages

Golubeva S.L.

Alternative Internet communication systems

Savelieva D.A., Gerasimova A.I., Yarmukhametov I.V.

Cultural identity. Empathy and sympathy as a prism of perception of native and foreign

culture 


\title{
Гаврилкова Н.Ю. Экономическая эффективность производства в зерновой отрасли
}

\author{
Gavrilkova N.Yu. \\ Economic efficiency of production in the grain industry
}

Развитие возможностей зернового хозяйства для повышения экономической эффективности деятельности сельскохозяйственных организаций Ключевые слова: производство зерна,

экономическая эффективность

\section{Гаврилкова Наталья Юрьевна}

Кандидат экономических наук, доцент

Красноярский Государственный Аграрный

Университет Ачинский филиал

Красноярский край, г. Ачинск, ул.

Коммунистическая, 49
Development of possibilities of a grain farm for increase of economic efficiency of activity of the agricultural organizations

Key words: grain production, economic efficiency

\section{Gavrilkova Natalya Yurievna}

Candidate of Economic Sciences, Associate Professor Krasnoyarsk state agrarian university Achinsk branch

Achinsk, Kommunisticheskaya st., 49

Производство зерна было и остается основой развития всего сельскохозяйственного производства России. В целях увеличения производства зерна и подъема уровня ведения зернового хозяйства в середине прошлого столетия был осуществлен комплекс государственных мер. Потенциал зернового хозяйства - один из наиболее крупных источников национального богатства. В современных условиях зерновое производство может стать основным звеном в цепи мер по выходу АПК из кризиса. Природно-климатические условия Сибири благоприятны для производства зерна, эта отрасль способна приносить максимальный доход. Сельскохозяйственный природно-ресурсный потенциал Сибири позволяет удовлетворить потребности населения региона в основных продуктах питания за счет местного производства.

В нашей стране эффективность аграрного производства нельзя рассматривать без учета её уникальных особенностей - обширной территории и разнообразия природно-климатических, социальных и экономических условий хозяйствования эффективность функционирования зернового хозяйства и рынка зерна во многом определяется территориально-отраслевым разделением труда, которое является импульсом для их развития, либо тормозом. Эти особенности должны быть объектом постоянного внимания ученых при решении проблем обеспечения продовольственной безопасности страны и повышения жизненного уровня её сельских жителей. 
В решении этой сложной и многоаспектной проблемы роль отдельных регионов неодинакова, поскольку территориальные особенности почвенных, климатических и экономических условий ведения зернового хозяйства предопределяют существенные региональные различия в наборе возделываемых зерновых культур, уровне интенсивности и эффективности зернового производства, объемах межрегиональных поставок зерна, формировании его экспортных ресурсов.

В последние годы катастрофически снижается отечественный потенциал зернового хозяйства, занятость населения в сельской местности, производительность труда, эффективность сельскохозяйственного производства в целом, из года в год сокращаются инвестиции, полностью разрушен механизм эквивалентного обмена между товарным производством зерна и другими сферами агропромышленного комплекса.

Непременным требованием эффективного развития любой отрасли народного хозяйства является устойчивость производства. В условиях рыночных отношений возрастает роль устойчивости производства, которая выступает непременным требованием эффективности развития зерновой отрасли. Нестабильность аграрного производства отрицательно сказывается на функционировании экономики страны, приводит к неустойчивой работе перерабатывающих отраслей, ухудшает экономическое положение товаропроизводителей. Устойчивость сельского хозяйства остается решающим фактором восстановления и дальнейшего развития всех отраслей АПК.

Значительно возросла техническая оснащенность зернового хозяйства, повысилась материальная заинтересованность организаций в увеличении производства зерна. Зерновое производство близко затрагивает экономические интересы других сфер экономики, в связи, с чем первоочередное его развитие будет создавать необходимые условия для повышения эффективности не только сельского хозяйства, но и АПК в целом.

Несмотря на сложность реформирования экономики и имеющиеся финансовые издержки из всех отраслей сельского хозяйства, зерновое хозяйство может оказаться наиболее эффективной отраслью.

Одна из причин относительно высокой доходности зернового хозяйства в том, что зернопроизводители более независимы в вопросах реализации, чем производители молока и некоторых других видов сельскохозяйственной продукции. Возможность длительного хранения выращенного урожая на элеваторах или собственных складских помещениях позволяют оптимизировать сроки реализации зерна с учетом текущей ценовой конъюнктуры не местном зерновом рынке, ожидаемых межрегиональных закупок экспортно-импортных операций $[1$, с.60].

Другое направление развития зернового хозяйства - стимулирование внутреннего спроса на зерно, что связано в первую очередь с развитием животноводства. Ныне на закупку животноводческой продукции за рубежом государство расходует значительные средства, тогда как собственное производство молока, мяса и другой животноводческой продукции позволит сократить расходы на закупку продукции, повысить занятость населения [3, с.71]. 
От эффективности ведения зернового хозяйства в значительной степени зависит состояние животноводства, и, в конечном счете, обеспеченность населения основными отечественными продуктами питания. Из двоякого значения зерна как конечного продовольственного товара как средства производства для животноводства формируются отправные моменты агарной политики государства.

Эффективность производства есть отношение полученного эффекта к затратам на его получение. Для расчета эффективности сельскохозяйственного производства необходимо определить и затем сопоставить полученный эффект с размером потребовавшихся для этого затрат и ресурсов.

Экономическая эффективность зернового производства предполагает получение максимального качества необходимой обществу зерновой продукции с каждого гектара при наименьших затратах живого и овеществленного труда в расчете на единицу продукции и на этой основе получения максимума прибыли.

Эффективность зернового производства напрямую зависит от продуктивности зернового клина. Стремясь увеличить производство зерна, многие хозяйства расширяют посевы зерновых за счет сокращения площади зерновых, технических и других культур. Это приводит к монокультуре зерновых, сокращению состава на зерновых предшественников, что в свою очередь ухудшает фотосанитарное состояние полей, снижает общую урожайность зерновых, устойчивость производства зерна. Решать эту задачу возможно главным образом на основе интенсификации зернового производства, рационального использования производственных ресурсов и почвенно-климатического потенциала отрасли.

Повышение эффективности зернового производства во многом зависит от структуры посевных площадей зерновых культур, которая должна совершенствоваться с учетом более полного удовлетворения потребности в продовольственном и фуражном зерне.

Сложившиеся новые обстоятельства на рынке продовольствия требуют создания нового действенного механизма повышения экономической эффективности для всего аграрного сектора. По поводу поиска и обоснования, наиболее действенных мер повышения эффективности зернового подкомплекса существует много различных мнений, но, к сожаленью, их реальность зачастую весьма сомнительна, а их реализация многих из них требует больших бюджетных средств и значительного периода освоения. В настоящее время практика ведения производства в зерновом подкомплексе не располагает ни тем, ни другим поэтому, наиболее целесообразными являются разработки, реализация которых повышает экономическую эффективность производства в рассматриваемом подкомплексе без особых затрат и в относительно короткие сроки.

В стране уже давно объективно назрела необходимость переориентации развития зернового хозяйства на формирование специализированных зон по производству отдельных видов зерна преимущественно в тех регионах, где они дешевле и более качественны, как это происходило целенаправленно и 
под контролем государства. Этот динамичный процесс постоянно осуществляется в экономически развитых странах, где государство не только способствует более рациональному размещению зернового производства, но и регулирует его по средством разного рода организационных, экономических и законодательных мер на межнациональном, национальном и региональном уровнях. В этой связи исключительное значение приобретает анализ динамики цен на зерно на региональных рынках, выявление соответствующих закономерностей и тенденций, а также выработка конкретных рекомендаций для принятия хозяйственных решений [2, с.66].

Эффективность функционирования зернового подкомплекса АПК в значительной мере зависит от уровня оснащенности и использования зерноуборочной техники, её производительности, напрямую формирующей уровень урожайности и валовые сборы зерна.

В повышении эффективности функционирования зернового подкомплекса заинтересовано все население страны, так как его результативность непосредственно определяет уровень рыночных цен на продукты питания зернового происхождения. Заинтересованность предпринимателей в росте эффективности так же очевидна, чем больше будет производиться и, чем дешевле будут обходиться зерновые продукты, тем выше будут их доходы (прибыль). В этих условиях зернопроизводители смогут выделять большие средства для расширения и укрепления своего бизнеса, будут большие возможности для занятости населения и роста его благосостояния.

Ситуация, сложившаяся в зерновом хозяйстве и на рынке зерна, может быть оптимизирована лишь при реализации в стране национальной зерновой политики. Она должна исходить из необходимости устойчивого и эффективного функционирования зернового хозяйства и смежных с ним отраслей экономики, формирования развитого зернового рынка в целях более полного и надежного удовлетворения как внутренней потребности в зерне, так и для увеличения его экспорта.

\section{Список литературы:}

1. Задков А., Долгушина М. Стратегия развития зерна в хозяйственном году // АПК: экономики и управление. 2014. № 2.

2. Кочетков В., Купырева Л. Совершенствование территориально-отраслевого разделения труда в зерновом производстве как фактор формирования развитого зернового рынка // Экономика сельского хозяйства Росии. 2013. № 12.

3. Липницкий Т. Производства зерна -узловая проблема развития АПК России // АПК: экономики и управление. 2014. № 5.

(C) 2015, Гаврилкова Н.Ю.

Экономическая эффективность производства в зерновой отрасли
(C) 2015, Gavrilkova N.Yu.

Economic efficiency of production in the grain industry 


\title{
Денисова Н.И. \\ Современный механизм оказание консультационных услуг в сфере АПК
}

\author{
Denisova N.I. \\ The modern mechanism of rendering consulting services \\ in the agrarian and industrial complex sphere
}

Статья раскрывает механизм функционирования информационно-консультационных служб региона, цель, задачи деятельности. Определяет перспективные направления развития региональной информационно-консультационной службы

Ключевые слова: информационно-

консультационная служба, механизм, запросы, информация

\section{Денисова Наталья Ивановна}

Кандидат экономических наук, заведующая кафедрой

Московский Университет им. С.Ю. Витте (филиал) 2. Рязань, Первомайский проспект, 62
Article opens the mechanism of functioning is information-consulting services of the region, the purpose, problems of activity. Defines the perspective directions of development regional it is informationconsulting service

Key words: Information-consulting service, the mechanism, inquiries, information

\section{Denisova Natalya Ivanovna}

Candidate of Economic Sciences, Head of

Department

Moscow University named S.Yu. Witte

Ryazan, Pervomaysky ave., 62

Под системой информационно-консультационного обеспечения АПК следует понимать совокупность взаимодействующих элементов управления, образования, науки и обслуживающей производственной инфраструктуры, составляющих целостное синергетическое образование, основным направлением которой является эффективный сбор, обработка, хранение и передача информации отраслевым товаропроизводителям, оказание помощи в профессиональном ее использовании.

В Рязанской области информационно-консультационная служба создана в составе областного управления сельского хозяйства, имеющего филиалы (информационно-консультационные пункты) во всех районах.

Функции информационно-консультационной службы АПК в Рязанской области предусматривают:

- обеспечение создания и деятельности системы рыночной информации;

- обеспечение доведения обработанной информации до руководящих органов области, организация и предприятий, поставщиков и покупателей; 
- взаимодействие с подразделениями Минсельхозпрода РФ и Главного информационно-консультационного центра;

- обеспечение издания и распространение бюллетеней, сборников, справочной, информационно-рекламной, учебно-методической литературы по вопросам деятельности системы информации о рынке и информационноконсультационной службы и др.

Структура запросов в ИКС по отраслям знаний в динамике 2002-2012гг. представлена на рисунках 1-3.
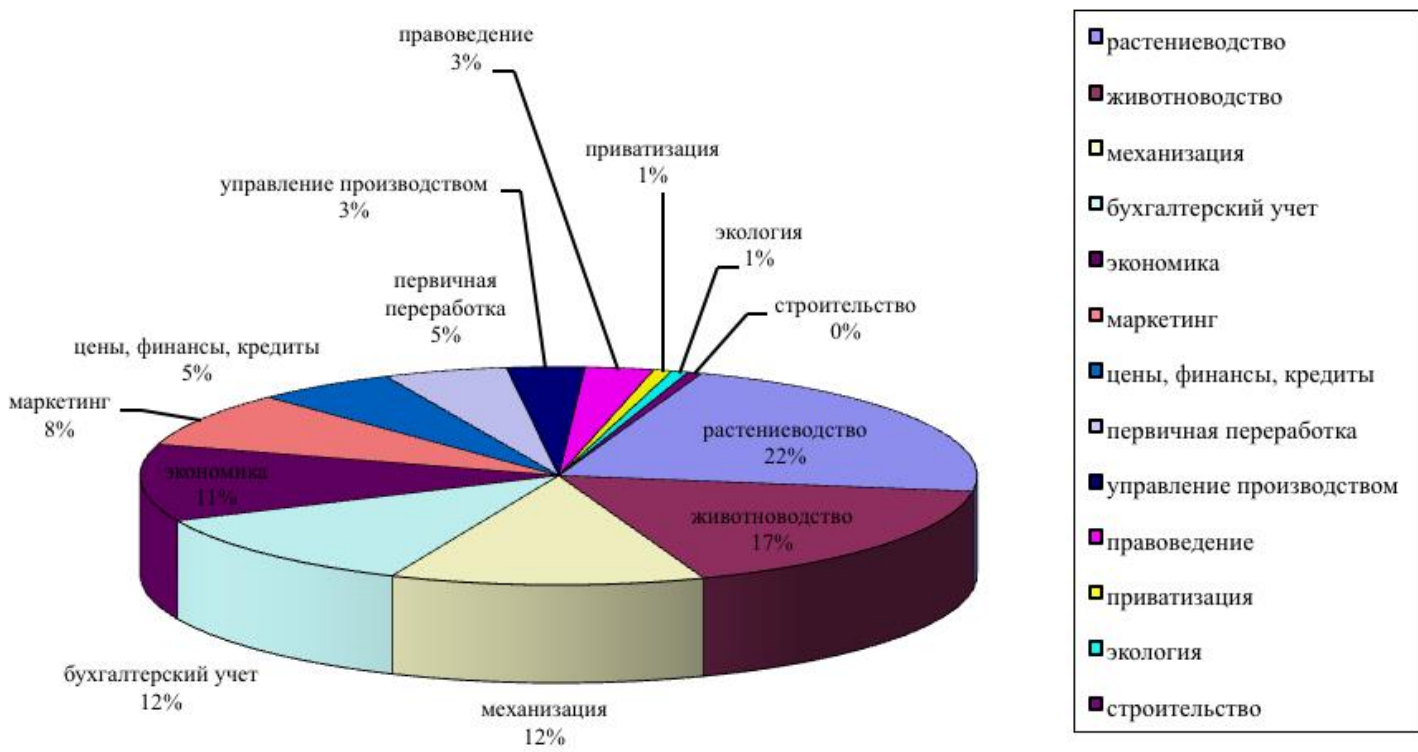

Pис. 1. Распределение запросов по отраслям знаний в 2002 году

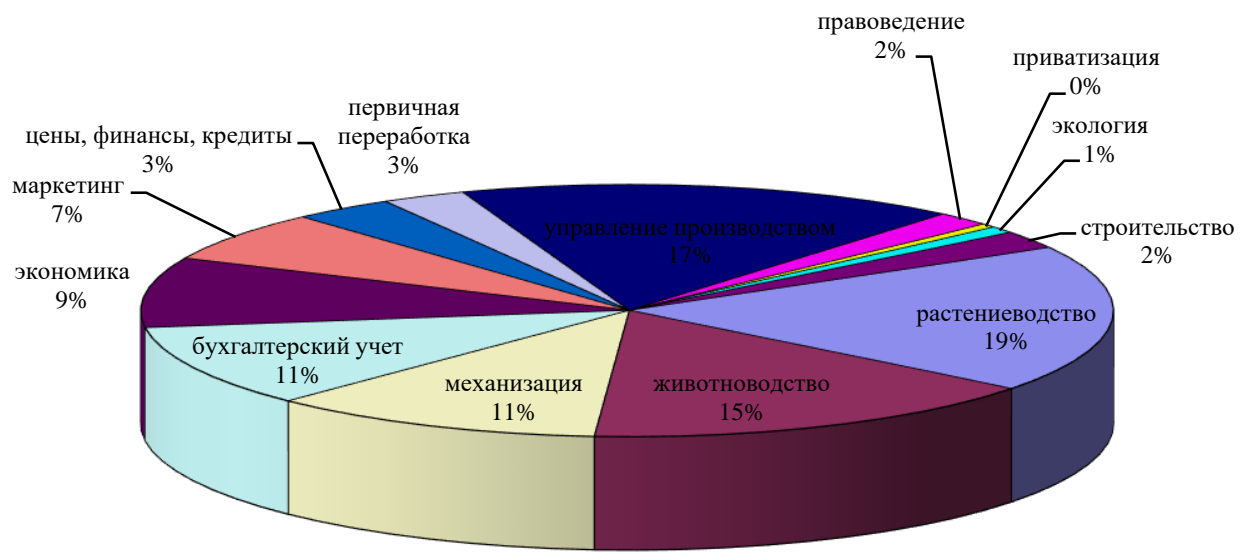

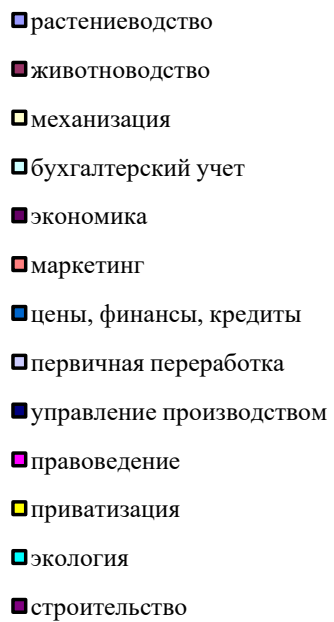

Рис. 2. Распределение запросов по отраслям знаний в 2004 году 


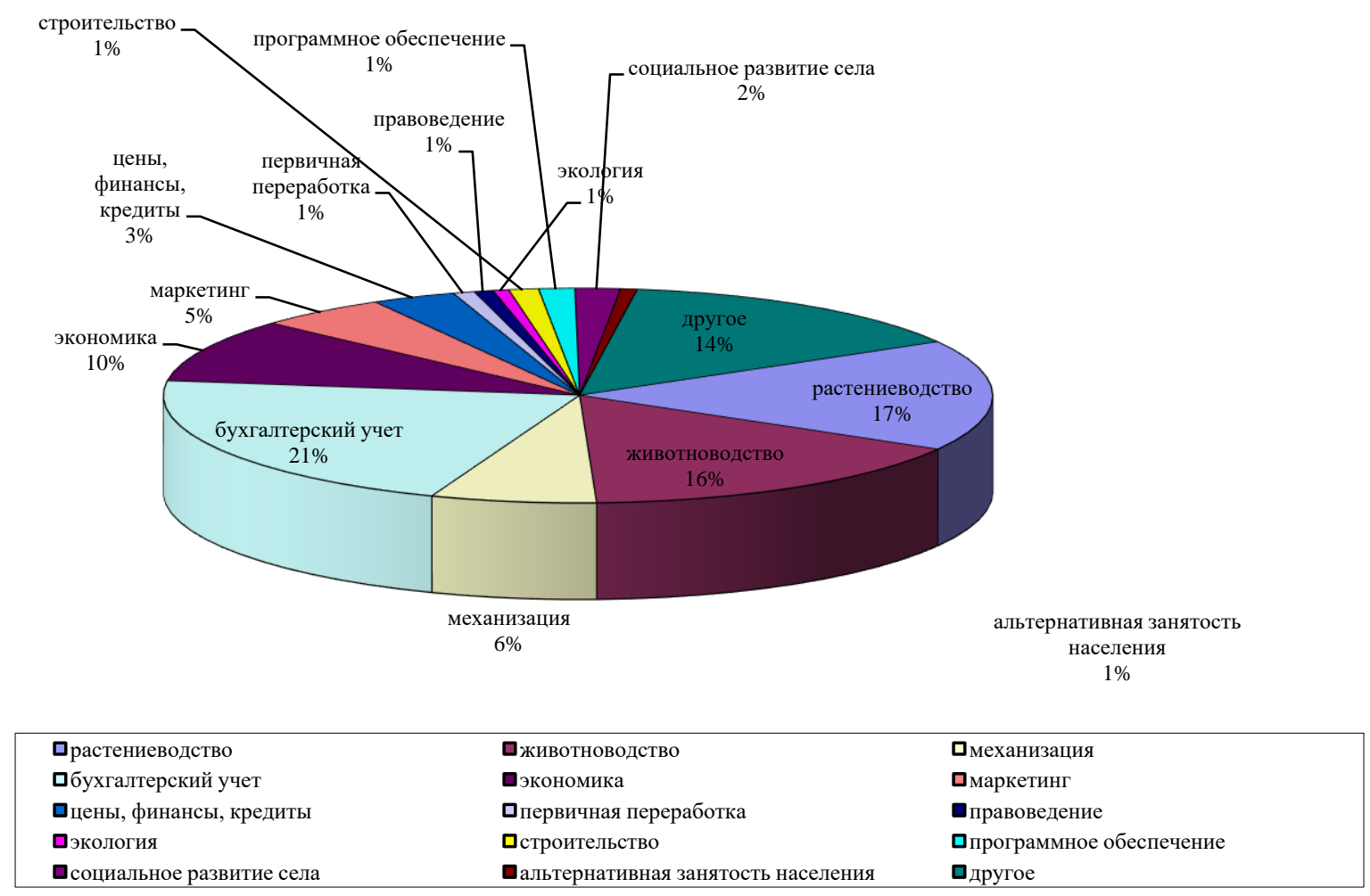

Рис. 3. Распределение запросов по отраслям знаний в 2012 году

Анализ распределения запросов по отраслям знаний показал, что в 2002 году их наибольшее количество поступило по растениеводству - 21\%. В 2012 году количество запросов по растениеводству снизилось на 4\%, а наибольшее количество запросов поступило по бухгалтерскому учету.

В 2012 году в структуре запросов появились, такие направления, как программное обеспечение и социальное развитие села, а так же альтернативная занятость населения.

Заметно сократилось количество запросов в сфере механизации. Данные запросы в 2012 году составили только 6\% от общего количества. В 2010 году в структуре запросов они составляли $-12 \%$.

Функционирование ИКС в России, в том числе и в Рязанской области не обходится без проблем.

Во-первых, возникли организационно-правовые проблемы связанные с неопределенностью в статусе и месте информационно-консультационных центров, созданных на районном уровне. Определение "при органах управления АПК", используемое в инструктивных материалах и совместных приказах администраций регионов и Минсельхозпрода РФ, является недостаточным и юридически неопределенным.

Второй проблемой является недостаток финансирования деятельности информационно-консультационной службы из федерального, регионального и местного бюджетов, а так же неэффективный механизм оказания информационно-консультационной службой платных услуг.

В целях дальнейшего развития ИКС нами разработаны следующие перспективные направления: 
- определение и закрепление правового статуса информационноконсультационных служб в регионах;

- совершенствование нормативно-правовой базы и организационноэкономического механизма функционирования информационноконсультационной службы;

- разработка эффективного механизма платных услуг, оказываемых информационно - консультационной службой;

- обеспечение финансовой поддержки, как на федеральном, так и на региональном уровне, выявление наиболее важных проблем ИКС, поддержка в их решении с учетом ресурсных возможностей региона;

- признание органами власти и управления АПК регионов, что функционирование ИКС является приоритетным направлением, необходимым для эффективного развития сельского хозяйства;

- организация подготовки и переподготовки кадров для ИКС, привлечение специалистов с опытом работы;

- обеспечение взаимодействия ИКС с учеными, специалистами региональных научных центров, НИИ, ВУЗов;

- организация рекламы и пропаганды деятельности информационноконсультационных служб, как на федеральном, так и на региональном уровнях.

Следует отметить, что уровень информационно-консультационного обеспечения предприятий сферы АПК влияет на уровень региональной продовольственной безопасности.

Продовольственная безопасность определяется аграрной политикой государства во всех ее направлениях, включая финансовую поддержку производителей, защиту их интересов, развитие материально-технической базы $[1,102]$.

Уровень продовольственной безопасности России формируется региональными продовольственными рынками, которые, в свою очередь, обладают рядом специфических особенностей, вызванных чрезвычайным разнообразием природно-климатических условий, неравномерностью размещения производственно-экономического потенциала, социальной инфраструктуры [2, 130].

\section{Список литературы:}

1. Денисова Н.И. Продовольственная безопасность России: проблемы, перспективы //

Вестник Рязанского государственного агротехнологического университета им. П.А. Костычева. 2014.

№ 1. С. 101-105.

2. Денисова Н.И., Шашкова И.Г. Обеспечение продовольственной безопасности региона в отрасли животноводства // Вестник Рязанского государственного агротехнологического университета им. П.А. Костычева. 2012. № 4. С. 130-133.

\section{References:}

1. Denisova N.I. Food security of Russia: problems, prospects // Bulletin of the Ryazan state agrotechnological university of P.A. Kostychev. 2014. №1. Pp. 101-105.

2. Denisova N.I., Shashkov I.G. Ensuring food security of the region in branch of animal husbandry //

Bulletin of the Ryazan state agrotechnological university of P.A. Kostychev. 2012. №4. Pp. 130-133.

(C) 2015, Денисова Н.И.

Современный механизм оказание консультационных услуг в сфере АПК
(C) 2015, Denisova N.I.

The modern mechanism of rendering consulting services in the agrarian and industrial complex sphere 


\title{
Дюженкова Н.В., Комбаров В.А. Современное состояние рынка телекоммуникационных услуг в России
}

\author{
Dyuzhenkova N.V., Kombarov V.A. \\ The modern state of the market of \\ telecommunication services in Russia
}

Дано понятие телекоммуникационной услуги и показаны ее особенности. Отмечены современные тенденции на рынке телекоммуникационных услуг. Охарактеризованы основные потребители телекоммуникационной услуги

Ключевые слова: телекоммуникационные услуги, анализ рынка

\section{Дюженкова Наталия Владимировна}

Кандидат экономических наук, доцент

Тамбовский государственный технический университет

г. Тамбов, ул. Советская, 106

\section{Комбаров Владимир Александрович \\ Начальник участка \\ ОАО «Ростелеком» \\ 2. Тамбов, ул. Астраханская, 2 B}

The definition of telecommunications services is given. A current trends in the telecommunications market are described. The main consumers of telecommunications services are characterized

Key words: telecommunication services, market research

\section{Dyuzhenkova Natalia Vladimirovna}

Candidate of Economic Sciences, Associate Professor Tambov state technical university

Tambov, Sovetskaja st., 106

Телекоммуникационные услуги включаются передачу звуковой информации, изображений и других информационных потоков через системы кабельной, радиотрансляционной, релейной или спутниковой связи, включая телефонную, телеграфную связь и телекс; услуги по аренде и техническому обслуживанию сетей передачи звука, изображения и данных. К данному виду услуг относятся услуги провайдеров - организаций, предоставляющих доступ в сеть Интернет. Таким образом, телекоммуникационная услуга - продукт деятельности оператора и/или провайдера телекоммуникаций, направленный на удовлетворение потребностей потребителей в сфере телекоммуникаций. В настоящее время рынок телекоммуникационных услуг в Российской Федерации активно развивается. Для реализации услуг продолжают появляться новые технологии, вызывающие интерес со стороны предприятий и населения. Основными сегментами рынка телекоммуникационных услуг являются услуги 
телефонной связи, мобильной связи, передачи данных через Интернет, спутниковое телевидение.

Для рынка телекоммуникаций характерны высокие темпы роста по сравнению с другими отраслями, активное внедрение новых технологий, изменение структуры предоставляемых услуг. Сегодня всё чаще отмечается перенос объемов пользования с традиционных телекоммуникационных услуг к новым видам, таким как предоставление услуг на основе мультисервисных транспортных сетей, широкополосный Интернет-доступ, технологию мобильной связи третьего поколения, включающую набор услуг, которые объединяют как высокоскоростной мобильный доступ с услугами сети, так и технологию радиосвязи, которая создает канал передачи данных.

Отчеты крупных операторов связи за 2014 год подтверждают главную тенденцию развития отечественного рынка телекоммуникаций. Количество пользователей скоростного Интернета увеличилось более чем в два раза, по сравнению с предшествующим годом, соответственно и доля доходов в этом сегменте также возросла. В то же время усиливается миграция голосового трафика в сети Интернет-телефонии, развитие получают технологии виртуализации и аутсорсинг - создание веб-ресурсов, разработка, установка, сопровождение программного обеспечения, обслуживание техники специальными компаниями. Несмотря на складывающуюся макроэкономическую ситуацию, ожидается увеличение числа подключений, повышение скорости и качества передачи данных при сохранении и, возможно, снижении ценовых показателей.

Сейчас большинство операторов делают акцент на наиболее дешевых и проверенных услугах, расширяя абонентскую базу при минимуме инвестиций. Но в то же время есть операторы, использующие снижение темпов развития конкурентов в своих интересах, таким образом, привлекая клиентов новыми качественными услугами и разумными ценами.

Отрасль телекоммуникационных и информационных технологий является одним из важнейших секторов экономики, обеспечивающих функционирование других отраслей хозяйства и государства в целом. Без современной телекоммуникационной инфраструктуры в России невозможно ее вхождение в мировое экономическое и информационное пространство. Поэтому правительство Российской Федерации рассматривает дальнейшее развитие телекоммуникационной инфраструктуры страны как один из главных факторов подъема национальной экономики, роста деловой и интеллектуальной активности общества, укрепления авторитета страны в международном сообществе. Дальнейшее качественное развитие услуг операторов связи особенно важно, если учесть, что потребность населения в телекоммуникационных услугах растет из года в год. Несмотря на бурное развитие услуг связи за последние пять лет, рынок телекоммуникационных услуг России все еще далек от степени насыщения.

Количество пользователей интернета в России достигло уже 69 миллионов человек, а их ежегодный прирост составляет порядка 7\%. При этом пользователи проводят в сети в среднем 121 минуту в день [1].

По данным Госкомстата России на конец 2014 года число активных абонентов фиксированного широкополосного доступа к сети Интернет в России 
составляет 24,8 млн. человек, а в Тамбовской области - 163,8 тыс. человек. Число активных абонентов подвижной радиотелефонной связи, использующих услуги доступа в Интернет на конец 2014 в России составило 105.8 млн. чел., а в Тамбовской области - 587 тыс. человек [2].

На сегодняшний день рынок находится под влиянием процессов слияний и поглощений, начало тренда было положено в 2009 году, когда крупнейшая российская телекоммуникационная компания ОАО «Ростелеком» была объединена сначала с межрегиональными компаниями связи, а затем с ОАО «Связьинвест». В следующем году было организовано объединение еще двух операторов: ОАО «МТС» и ОАО «Комстар-Объединенные ТелеСистемы». В конце 2013 года была осуществлена сделка по объединению ОАО «Ростелеком» и 000 «Tele2 Россия» [3].

На сегодняшний день на российском рынке телекоммуникационных услуг доминируют четыре игрока: мобильные операторы ОАО «МТС», ОАО «Мегафон» и ОАО «Вымпелком» и ОАО «Ростелеком». ОАО «Ростелеком» и большая тройка занимают 86\% рынка, при этом доля доходов ОАО «Ростелеком» составляет 25\% рынка, ОАО «МТС» - 24\%, ОАО «Мегафон» - 19\%, ОАО «Вымпелком»-18\% [4].

Таким образом, сценарий развития российского рынка телекоммуникаций полностью повторяет мировые тренды постепенного снижения роли традиционных голосовых услуг в общем объеме рынка, развитие высокоскоростных технологий связи и доступа к сети Интернет и является глобальной тенденцией. Ожидается, что российский рынок продолжит развитие в том же направлении с сохранением существующих трендов.

По данным опроса проведенного Левада-центр [5] ежедневно или несколько раз в неделю пользуются интернетом и электронной почтой чаще всего учащиеся и студенты (92\%), специалисты (86\%), руководители и управленцы (79\%) и в целом мужчины (71\%), россияне моложе 25 лет $(91 \%)$ и в возрасте 25-40 лет (84\%), с высшим образованием (76\%), высоким потребительским статусом - могут без особых проблем покупать товары длительного пользования (78\%), жители Москвы (76\%) и городов с населением более 500 тысяч человек (66\%).

За последние два года количество пользователей интернета в России возросло с 52\% до 62\%. Больше всего пользователей среди студентов и учащихся (92\%), специалистов, руководителей и управленцев (по 91\%), а меньше всего - среди пенсионеров (15\%). Среди россиян моложе 25 лет пользователей Интернета 91\%, а старше 55 лет - 23\%. Среди россиян с высшим образованием пользуются Интернетом 82\%, а с образованием ниже среднего - 45\%. Больше всего интернетчиков в Москве - 80\%, а меньше всего среди сельских жителей - 51\%.

В последнее время несколько изменились и интересы пользователей. Так, заметно больше они стали следить по Интернету за последними новостями и анализом событий в стране и за рубежом. Цели пользования Интернетом различаются в зависимости от принадлежности россиян к той или иной социально-демографической группе. 
Ищут в Интернете нужную информацию чаще всего опрошенные руководители и управленцы (78\% - от всех опрошенных), специалисты (76\%), учащиеся и студенты (67\%) и в целом россияне моложе 25 лет (67\%) и 25-40 лет (63\%), с высшим образованием (67\%), с высоким потребительским статусом (65\%), жители Москвы (69\%) и городов с населением более 500 тысяч человек (52\%) [5].

Для общения пользуются Интернетом больше других учащиеся и студенты (69\%), специалисты (61\%), домохозяйки (57\%), руководители и управленцы (51\%) и в целом россияне моложе 25 лет (70\%) и 25-40 лет (65\%), с высшим образованием (55\%), с высоким потребительским статусом (55\%) и проживающие в городах с населением более 100 тысяч человек (48\%).

Для развлечения используют всемирную сеть скорее всего учащиеся и студенты (63\%), специалисты (43\%), предприниматели (42\%) и в целом мужчины (32\%), россияне моложе 25 лет (59\%) и 25-40 лет (50\%), с высшим образованием (37\%), с высокими потребительскими статусом (42\%), жители Москвы (44\%) и городов с населением более 500 тысяч человек (32\%).

Для приобщения к кино и музыке чаще всего пользуются сетью учащиеся и студенты (59\% - кино и 60\% - музыка), руководители (соответственно 43 и $23 \%)$, специалисты (37 и $35 \%$ ) и в целом мужчины (31 и 25\%), россияне моложе 25 лет (по 52\%) и 25-40 лет (43 и 37\%), с высшим образованием (33 и 28\%), с высоким потребительским статусом (38 и 33\%), проживающие в Москве (48 и $42 \%$ ) и в городах с населением 100-500 тысяч жителей (29 и 28\%).

За последними новостями и для понимания происходящего больше других заходят в Интернет учащиеся и студенты (52\% - новости и $24 \%$ - аналитика), руководители (соответственно 45 и 37\%), специалисты (43 и 26\%) и в целом мужчины (30 и 21\%), россияне моложе 25 лет (36 и 23\%), с высшим образованием (39 и 25\%), с высоким потребительским статусом (41 и $26 \%$ ) и проживающие в Москве (49 и 45\%).

Для поиска и покупок товаров пользуются сетью чаще всего руководители (35\%), учащиеся и студенты (33\%), предприниматели (27\%), специалисты $(26 \%)$ и в целом россияне моложе 25 лет (28\%) и 25-40 лет (24\%), с высшим образованием (27\%), с высоким потребительским статусом (27\%) и жители Москвы (41\%).

Интересуются литературой в Интернете скорее всего студенты и учащиеся (39\%), руководители, предприниматели (по 23\%), специалисты (20\%) и в целом россияне моложе 25 лет (26\%) и 25-40 лет (21\%), с высшим образованием (17\%), с высокими потребительским статусом (20\%) и жители Москвы (26\%) [5].

Анализируя представленные данные опроса, можно сделать следующие выводы. В настоящее время при почти тотальном контроле «властной вертикали» основных каналов телевидения, формирующих общественное мнение большинства россиян по социально-политическим проблемам, Интернет начинает становиться их реальным конкурентом. Вполне вероятно с использованием возможностей Интернета создание оппозиционных политических партий способных уже на ближайших выборах преодолеть процентный барьер и 
быть представленными в Госдуме влиятельными фракциями. Эти реальную угрозу практической монополии власти одной партии понимают её руководители. Всё чаще в СМИ появляется информации об ограничениях свободы различного рода обмена информации в рунете [5].

Российское телевидение, а вместе с ними телезрителей, ждут перемены. В 2009 году в России дан старт переходу на новый - цифровой - формат эфирного телерадиовещания. Для того, чтобы в максимально сжатые сроки охватить всё население страны цифровым телерадиовещанием, постановлением Правительства Российской Федерации от 3 декабря 2009 г. №985 утверждена федеральная целевая программа «Развитие телерадиовещания в Российской Федерации на2009 - 2015 годы».

Согласно Программе, возможность бесплатного приёма общероссийских обязательных общедоступных телеканалов цифровом формате будет предоставлена населению России на базе государственной системы эфирного наземного телевизионного вещания, осуществляемого федеральным государственным унитарным предприятием «Российская телевизионная и радиовещательная сеть». Для доставки вещательных программ в регионы будут построены несколько тысяч наземных объектов связи и запущены новые космические аппараты.

Предполагается, что к концу 2015 года жители России смогут смотреть не менее 20 цифровых эфирных телеканалов, включая канал в формате телевидения высокой четкости.

В ходе реализации Программы решаются следующие задачи:

- модернизация инфраструктуры государственных сетей телевизионного вещания и переход на цифровые технологии телевещания;

- создание многофункциональных космических аппаратов для распределения телевизионных каналов по всем временным вещательным зонам;

- создание системы цифровизации архивных материалов, их обработки и классификации на базе ФГУ «Государственный фонд телевизионных и радиопрограмм»;

- развитие новых видов телевизионного вещания, включая телевидение высокой четкости.

Для обеспечения жителей страны многопрограммным цифровым телевизионным вещанием остаются востребованными и важными все виды телевизионного вещания. В конечном итоге цифровые технологии наземного, спутникового и кабельного вещания, а также технологии радиодоступа будут не вытеснять, а дополнять друг друга, что позволит обеспечить равные права граждан Российской Федерации на получение социально значимой информации [6].

Телевидение остается самым популярным источником информации для 88\% граждан, а половина россиян ему больше всего доверяет, выяснили социологи «Левада-центра». Интернет-издания у россиян не в почете: только $21 \%$ граждан узнает оттуда новости, доверяют сведениям из сети лишь 14\%. Эксперты утверждают, что россиянам вообще не нужны новости, а телевидение они используют как средство развлечения. 
«Чаще всего» население (88\%) узнает новости из телевизора, а половина граждан еще и доверяют этому СМИ больше всего. Таковы результаты исследования «Левада-центра». При этом четверть россиян (26\%) считают новостные выпуски на «Первом канале», «России» и НТВ «совершенно» и «по большей части» необъективными. Впрочем, по мнению половины опрошенных, события на этих телеканалах освещаются «по большей части» беспристрастно, а по мнению 12\% - «совершенно объективно».

Четверть граждан - 24\% - узнают новости от друзей, знакомых и родных, причем 15\% еще и доверяют больше всего именно этому «источнику информации». Интернет-издания только третий по популярности источник. 21\% «чаще всего» получает оттуда сведения о событиях в стране и за рубежом. Доверяют изданиям в сети 14\% граждан. Отметим, что совсем не пользуются интернетом 39\% россиян. Чаще всего люди выходят в сеть, чтобы найти нужную им информацию (41\%) и для общения (30\%), а не для того, чтобы узнать новости. Еще четверть граждан (26\%) используют интернет «для развлечения», столько же - чтобы зайти в социальные сети, почти четверть (24\%) - чтобы послушать музыку, 21\% - посмотреть фильмы. Отметим, что 27\% россиян помимо прочего следят в интернете за новостями и 16\% пользуются им, чтобы «разобраться, что происходит в стране и в мире».

Каждый пятый россиянин чаще всего узнает новости из газет, доверяют прессе 12\%. Радио пользуется популярностью у 10\% граждан, 11\% более всего ему доверяют. А 15\% черпают новости из социальных сетей, при этом 10\% доверяют такой информации [5].

\section{Список литературы:}

1. Министерство связи и массовых коммуникаций России.

URL: http://minsvyaz.ru/ru/news/index.php?id_4=44509

2. Единая межведомственная информационно-статистическая система.

URL: http://fedstat.ru/indicators/start.do

3. Газета «Ведомости».

URL: http://www.vedomosti.ru/tech/news/19014611/sozdanie-sp-rostelekoma-i-tele2-rossiya-

otkladyvaetsya\#ixzz2mhUnHhDx

4. Деловой журнал «ИнформКурьер-Связь».

URL: http://www.iksmedia.ru/news/4970493.html

5. Левада-центр, Аналитический центр Юрия Левады.

URL: http://www.levada.ru/11-11-2013/tseli-i-konfidentsialnost-rossiyan-v-internete

6. Министерство связи и массовых коммуникаций России.

URL: http://minsvyaz.ru/ru/directions/?direction=19

7. Маркетинговая стратегия как средство формирования оптимального портфеля заказов фирмы сферы информационного бизнеса // Качество информационных услуг. Тамбов, 2010. Bып.12. С. 63-65. 8. А.Л. Денисова, Н.В. Молоткова, М.А. Блюм, Т.М. Уляхин, А.В. Гуськов. Электронная коммерция: основы организации и ведения бизнеса Тамбов: ФБГОУ ВПО ТГТУ, 2012. 88 c.

(C) 2015, Дюженкова Н.В., Комбаров В.А. Современное состояние рынка телекоммуникационных услуг в России
(C) 2015, Dyuzhenkova N.V., Kombarov V.A.

The modern state of the market of telecommunication services in Russia 


\title{
Жердева И.В., Симоненко Н.Н. Принципы разработки и принятия решений по стратегии бизнеса
}

\author{
Zherdeva I.V., Simonenko N.N. \\ Principles for the development of financial business strategy
}

В статье разработаны принципы разработки финансовой стратегии бизнеса и принятие решений по его управлению

Ключевые слова: финансовая стратегия, принципы бизнес, решение

\section{Жердева Ирина Витальевна}

Магистрант

Комсомольский-на-Амуре государственный технический университет

г. Комсомольск-на-Амуре, ул. Ленина, 27

\section{Симоненко Николай Николаевич}

Доктор экономических наук, профессор, заведующий кафедрой

Комсомольский-на-Амуре государственный технический университет

2. Комсомольск-на-Амуре, ул. Ленина, 27

\begin{abstract}
In the paper, we develop principles for the development of financial business strategy and decision-making on its management

Key words: financial strategy, principles, business, solution

\author{
Zherdeva Irina Vitalievna \\ Undergraduate \\ Komsomolsk-on-Amure state technical university \\ Komsomolsk-on-Amure, Lenina st., 27
}

\author{
Simonenko Nickolay Nicolaevich \\ Doctor of Economic Sciences, Professor, Head of \\ Department \\ Komsomolsk-on-Amure state technical university \\ Komsomolsk-on-Amure, Lenina st., 27
}

Финансовая стратегия предприятия (бизнеса) является одним из важнейших видов функциональной стратегии предприятия, обеспечивающей все основные направления развития его финансовой деятельности - и финансовых отношений путем формирования долгосрочных финансовых целей, выбора наиболее эффективных путей их достижения, адекватной корректировки направлений формирования и использования финансовых ресурсов при изменении условий внешней среды [2]. Эта стратегия вырабатывается в результате долгосрочного финансового планирования.

Впервые общие принципы планирования сформулировал А. Файоль. В качестве основных требований к разработке программы действия или планов предприятия им были обозначены пять необходимых принципов: необходимость, единство, непрерывность, гибкость и точность [Бабич Т.Н, Кульбижев Э.Н. Планирование на предприятии. М., 2005], которые принципиально важны и в современных условиях деятельности. Многие из них применяются в планировании финансовой стратегии предприятия. 
В современной отечественной науке широкую известность имеют общеэкономические принципы, к которым относятся: системность, целенаправленность, комплексность, оптимальность, эффективность, научность, приоритетность, сбалансированность, занятость, директивность, самостоятельность, равнонапряженность и др. [4, с. 16-18].

Принцип системности - это рассмотрение определенной целостности, единства как множества элементов, находящихся в связях друг с другом.

Принцип целенаправленности предполагает ориентацию на четко сформулированную стратегическую цель деятельности предприятия. Все планируемые организационно-финансовые мероприятия должны обеспечивать достижение именно заданной цели. Реализация этого принципа обеспечивается применением метода дерева целей - совокупности соподчиненных и структурированных целей, начиная с главной цели и завершая целями первого уровня управления.

Принцип комплексности обязывает систему планов охватывать планированием все структурные уровни и все уровни предприятия и виды финансово-хозяйственной деятельности.

Принцип оптимальности - на всех этапах планирования следует обеспечивать выбор наиболее эффективных вариантов предприятия и его структур.

Принцип эффективности и экономичности - позволяет учитывать не просто эффект, а его соотношение с затратами. Вклад планирования в эффективность определяется усилением качества принимаемых решений.

Принцип научности - в современном планировании учитываются законы рынка, их проявление конкретной конкурентной среде, достижения науки и техники, и план должен носить инновационный характер.

Принцип приоритетности (выделения ведущего звена) означает, что ресурсное ограничение требует выделения приоритетов в развитии, а денежные потоки - дифференциации на приоритетных направлениях развития [4, c. 18]. Выбирая ту или иную финансовую стратегию, руководство предприятия должно быть готовым последовательно придерживаться ее линии, подчиняя свои тактические действия стратегическим приоритетам. Долгосрочная стратегическая линия является приоритетной и определяющей по отношению ко всей последующей работе.

Принцип сбалансированности - равномерное обеспечение программы производства всеми видами ресурсов.

Принцип равнонапряженности - для всех подразделений планы должны носить одинаково напряженный характер.

Принцип перспективности. Финансовое стратегическое планирование направлено на долгосрочную перспективу, и последствия принимаемых стратегических решений играют определяющую роль в судьбе предприятия на протяжении длительного времени.

Принцип реализуемости. При постановке долгосрочных целей и определении стратегии их достижения учитываются реальные возможности предприятия. Поэтому поставленные цели должны быть реализуемыми в обязательном порядке, а задачи - выполнимыми. 
Принцип итеративности (поэтапности). Внедрение финансовой стратегии в жизнь производится поэтапно: решение долгосрочных задач происходит через реализацию среднесрочных и краткосрочных целей. Таким образом, конечная стратегическая цель достигается за счет детальной последовательной работы.

Принцип комплексности. Всесторонний анализ и учет информации позволяет своевременно реагировать на изменения внешней и внутренней среды. Необходимо отслеживать все проблемные вопросы предприятия, знать, каким внутренним ресурсом располагает предприятие в настоящее время, сможет ли оно реализовать задуманную стратегию.

Принцип непрерывности мониторинга (сканирования) тенденций развития. Сканирование предполагает сбор информации, оценку и прогноз значимости для корпорации важнейших изменений во внешней социальноэкономической и технологической среде в целях подготовки стратегических решений на высших эшелонах управления.

Принцип селективности. Селективность финансового стратегического планирования связана с выделением определенных стратегических зон хозяйствования - отдельных сегментов рынка.

Принцип стратегической конкуренции. Основу стратегической конкуренции составляют: конкурентное взаимодействие; умение предвидеть последствия вмешательства в систему и прогнозировать новые модели устойчивого динамического равновесия; наличие свободных ресурсов; умение достоверно предсказать риск и отдачу для обоснования использования ресурсов.

Концепция, направленная на локализацию решения возникающих и прогнозируемых проблемных ситуаций, на своевременное выявление и локализацию узких мест процесса деятельности предприятия, централизацию и оптимизацию управленческих решений на новом качественном и правовом уровне, носит название контроллинга [4, с. 285]. Контроллинг является системой управления предприятием с интеграцией функций планирования, регулирования и контроля процесса достижения конечных целей с учетом проведения оптимизации результатов работы организации.

Управленческое решение является предметом и продуктом системы управления [7, с. 13]. Проблема принятия решений считается одной из ключевых науке и практике управления, и акт принятия решения - это центральный момент в процессе управления на любом его уровне. Термин решение понимают по-разному: это и процесс, и акт выбора, и результат выбора. Сам же процесс управления многие считают непрерывным процессом выбора и принятия решений. Существуют различные подходы к формированию классификаций решений. Например, сформированные группировки управленческих решений, основанные на различных признаках, выражающих важную сторону решения, представляют собой [7, с. 17]:

- решения по объекту управления;

- решения по субъекту управления;

- решения по цели управления;

- решения по продолжительности действия; 
- решения по адресности;

- решения по количественной определенности решения;

- решения по характеру предусмотренных действий;

- решения по степени неопределенности исходной информации.

Принимаемые управленческие решения должны соответствовать требованиям:

- научной обоснованности - они формируются с учетом объективных законов и закономерностей, действующих в сферах деятельности организации;

- целенаправленности - означает, что цель решения строго соответствует целям организации;

- количественной и качественной определенности - оно обеспечивает достижение определенного результата, выраженного в количественных и/или качественных показателях;

- правомерности - решение обусловлено нормами, определяющими компетентность органов управления, что позволяет заниматься профессиональной деятельностью, входящей в круг задач;

- оптимальности - или выбора в каждом конкретном случае варианта решения, соответствующему принятому критерию эффективности организации;

- своевременности решения - соблюдение сроков подготовки решения, доведения его до исполнителей и обеспечение контроля исполнения;

- комплексности - учет того, что изменение одних элементов ведет к изменению других элементов системы;

- реализации стимулирующей функции решения - действенность решения во-многом определяется исполнителем, который заинтересован в его результатах;

- гибкости решения - отсутствие его жесткости, возможность корректировки решения в результате воздействия других факторов;

- полноты оформления решения - отсутствие неполноты или двойственности понимания поставленных задач перед исполнителями.

Для организации процесса разработки управленческого решения отработана конкретная методология, а как самостоятельное научное направление теория принятия решений начиналась с работ Дж. фон Неймана и О. Моргенштейна.

На сегодня в общей классификации представлено большое число методов разработки решений. Однако любое решение связано с проблемой, которая возникает перед органом управления. В современной теории и совокупности методов принятия решений научные подходы вполне сочетаются с организационными, интеллектуальными и психологическими способностями и опытом людей, что характеризует искусство принятия решений.

Принятие решений является всего лишь одной из задач, решаемых менеджером. При этом принятие решений - это типично управленческая задача, заслуживающая специального рассмотрения в рамках анализа эффективности деятельности менеджера. 
Как и всякий процесс, принятие решений, в котором участвует человек, имеет объективную и субъективную стороны. Объективная сторона этого процесса находится вне сознания человека и независимо от его воли, и она представлена совокупностью связей и обстоятельств, свойственных определенным условиям: сформулированной цели, состояния процесса и внешним условиям. Субъективная сторона процесса заключена в том, что объективное отражается в сознании человека и в принимаемом им решении. Это отражение не точно и не полно относительно объективной реальности, что вовсе не означает, что не может быть найдено лучших и хороших решений. Плохие решения часто не соответствуют сформулированной цели либо отражают складывающуюся обстановку не вполне объективно.

Следовательно, для принятия лучшего или хорошего решения необходимо, чтобы объективное, то есть цель, обстановка и прочее, не зависящее от воли и сознания, воспринималось как можно точнее. Это означает, что принятие лучшего или хорошего решения требует достаточно обширных и глубоких знаний о объекте. Однако сами знания без необходимого опыта, навыков далеко не всегда могут быть реализованы на практике. В реальной производственной жизни на предприятии решения принимаются непрерывно в каждом его подразделении, элементе системы управления, которые в свою очередь, как правило, являются системами управления предприятия второго уровня, и это обеспечивает с необходимой оперативностью и достаточно высокой степенью вероятности принятие лучших решений.

Существенное значение в принятии решений имеют творчество и инициатива. Творчество заключается в том, чтобы требования более высокого уровня управления применялись на нижерасположенных уровнях, с учетом с реальной обстановки. Инициатива - это ответная реакция на изменения и на вновь появившиеся возможности. При этом творчество и инициатива уместны, когда они согласуются с целью, соответствуют ей и позволяют ее достижение с меньшими затратами ресурсов.

Представление решения как целого, но раскладываемого при анализе на составляющие части, создает условия для сопоставления элементов решения со сформулированной целью как с критерием, данными третьего порядка со своими элементами и связями. Разработать в каждом из них критерии для принятия решения, определяющего успех предприятия целиком, довольно сложно. Учитывая все разнообразие и количество принимаемых персоналом решений, это практически невозможно. Частично эта проблема может быть решена через создание производственной идеологии, применяя которую векторы цели подразделений, работников могут быть направлены в сторону вектора цели предприятия или, по крайней мере, приближены к нему. Таким образом, возникает механизм реализации закона композиции: цели на каждом уровне управления поддерживают главную цель. Так же используется инициатива персонала, направленная на достижение стоящих перед организацией задач.

Однако целиком проблема решена быть не может, поскольку для ориентирования всех решений на достижение общей стоящей перед организацией цели требуется персонал очень высокой квалификации и с единым стереоти- 
пом мышления. Собрать на реальном предприятии такой персонал практически невозможно. Поэтому для принятия оптимальных решений необходим доступный и достаточно простой для понимания и применения персоналом метод их разработки, и аналитическая оценка, на сколько и в какой степени признаки и свойства каждого элемента позволяют достигнуть цель или продвинуться к ней. Это важное обстоятельство дает возможность создать у персонала оптимистичный настрой на решение проблемы.

От эффективных управленцев, конечно, ожидают и эффективных решений. Такие менеджеры систематически и в определенной последовательности принимают управленческие решения. Но процесс этот значительно отличается от того, что во многих рекомендациях представлено как «принятие решений.

Главное отличие отличается тем, что эффективные менеджеры не стремятся принимать множество решений, они сосредоточиваются только на самых важных. Мыслят они стратегическими и масштабными категориями и не ставят себе цель «решить текущие задачи». Они стараются принять те немногие важные решения, которые находятся на высшем уровне концептуального понимания; стараются найти постоянные величины в любой ситуации. Именно поэтому эффективные менеджеры при принятии решения не принимают во внимание фактор временных затрат. Более того, они рассматривают виртуозное манипулирование множеством переменных как признак небрежного мышления [8]. Эффективные менеджеры, отчетливо представляют себе смысл решения как такового и те реальности, которые это решение призвано удовлетворить, все-таки отдают предпочтение воздействию, нежели технике исполнения, стремясь быть здравомыслящими, а не хитроумными. До тех пор, пока решение не воплотилось в действительность, оно остается только благим пожеланием. Это означает, что в то время, пока принимаемое эффективное решение основывается на высочайшем уровне концептуального понимания, действие по его практическому применению должно быть максимально простым и носить максимально оперативный характер.

Как правило, решения принимают только руководители. Однако применяемый в Японии метод «Ринги», формирующий решение от исполнителя вверх по управленческой лестнице и каждый раз, при наличии замечаний возвращающий решение ему на доработку, в принципе позволяет считать возможность принятия решения непосредственно исполнителем.

Ицхак Адизес выделил четыре функции, которые должен выполнять менеджмент в любой организации [1, с. 22]:

1) producing, или производство результатов. Удовлетворять потребности потребителей, тем самым обеспечивая результативность организации в краткосрочном аспекте;

2) administrating, или администрирование. Направлено на обеспечение порядка в организационных процессах: производство необходимой потребителю продукции в строгой последовательности и с заданной интенсивностью. Обеспечивает эффективность в краткосрочном периоде; 
3) entrepreneur, творческий подход к делу и готовность рисковать. Выполнение этой функции обеспечивает спрос на продукцию организации у будущих клиентов, или результативность в долгосрочном периоде;

4) integrating, интеграция, или создание атмосферы и системы ценностей, направленных на совместную деятельность людей без статуса незаменимости, что обеспечивает результативность в долгосрочном периоде.

Раскрытые функции менеджмента (Р - Что?; А - Как?; Е - Когда?; I - Кто?) содержат в себе конкретный тип задач при решении возникающих проблем. И. Адизес выделил, что менеджмент является слишком сложным процессом, чтобы его успешно выполнял один человек [там же, с. 26].

Питер Друкер, понимая всю сложность управленческой работы, ранее отмечал, что для решения задач, стоящих перед высшим менеджментом, требуется по меньшей мере четыре типа людей. Людей, сочетающих в себе эти четыре типа, практически нет [9, p. 316].

Питером Друкером разработано несколько эффективных стратегий для бизнеса, в частности, стратегии специализации, диверсификации и интеграции. Он показал, что каждый бизнес должен иметь сердцевину - область, в которой бизнесмен стремится быть впереди всех. Это свидетельствует о необходимости специализации. Поскольку каждый бизнес намерен пытаться получить максимум дохода от собственной специализации, он должен для этого быть способным к диверсификации. Предпринимательская компания может быть диверсифицирована по товарам, рынкам и конечным применениям и быть сконцентрированной либо на своей области базового знания, либо диверсифицироваться в своей области знания и сконцентрироваться на своих товарах, рынках и конечных применениях. Все промежуточные варианты в таких случаях не могут быть удовлетворительными. В интеграцию Друкер также включил осуществление слияний и приобретений, осуществление решений о покупке и строительстве, что можно считать некоторым упрощением, сделанным с этической позиции для сотрудников приобретаемой компании с целью снижения негативного отношения к новой компании.

Диверсификация не всегда бывает эффективной, она может быть и ошибочной [6]. Согласно Друкеру, правильная диверсификация приводит к созданию бизнесов, производительные возможности которых примерно соответствуют возможностям лидеров из группы высококонцентрированных компаний одного рынка или одной технологии, а неправильная, ошибочная диверсификация порождает бизнесы, работающие также плохо, как и фирма одного рынка или одной технологии, сконцентрированная в неправильном бизнесе [3].

Стратегические решения всегда ориентированы на будущее. С этой позиции, по Друкеру, каждая экономическая задача должна соответствовать трем организационно-экономическим критериям [цит. по 5, с. 228]:

- текущий бизнес она должна сделать эффективным;

- способствовать выявлению и реализации потенциала бизнеса; 
- решение задачи должно быть таким, чтобы текущий бизнес привести к созданию нового, способного действовать во внешней среде будущего, отличающегося от настоящего.

\section{Список литературы:}

1. Адизес И. Стили менеджмента - эффективные и неэффективные. М.: Альпина Паблишер, 2014. $198 \mathrm{c.}$

2. Бланк И.А. Финансовая стратегия предприятия. К.: Эльга, Ника-центр, 2004. 720 c.

3. Друкер П. Менеджмент. Вызовы ХХІ века. М.: Манн, Иванов и Фербер, 2012.

4. Савкина Р.В. Планирование на предприятии. М.: Дашков и К, 2014. 320 с.

5. Симоненко Н.Н., Симоненко В.Н. Управление бизнес-процессами в предпринимательской деятельности. КнАГТУ: КнАГТУ, 2014. 232 с.

6. Симоненко Н.Н. Технология создания будущего бизнеса // Международный журнал прикладных и фундаментальных исследований. 2013. № 10-1. С. 104-108.

7. П.В. Шеметов Управленческие решения: технологии, методы и инструменты. М.: Омега-Л, 2014, 398 c.

8. Щесняк К.Е. Докторант Российского университета дружбы народов. Москва.

URL: http://www.m-economy.ru/art.php?nArtId=3549

9. Drucker, Peter F. Management: Tasks, Responsibilities, Practices. New York: Harper \& Row, 1973.

(C) 2015, Жердева И.В., Симоненко Н.Н. Принципы разработки и принятия решений по стратегии бизнеса
(C) 2015, Zherdeva I.V., Simonenko N.N. Principles for the development of financial business strategy 


\title{
Лабусов М.В. \\ Безработица как социальное явление и социальный процесс
}

\author{
Labusov M.V. \\ Unemployment as a social phenomenon and a social process
}

В современной рыночной экономике безработица является одним из наиболее значимых социальноэкономических явлений. В большинстве случаев она рассматривается как негативное явление. Для подтверждения данного высказывания необходимо чётко осознавать сущность, особенности практического проявления безработицы. Это позволит не только правильно понимать данное социально-экономическое явление, но и определять дальнейшие направления его исследования

Ключевые слова: безработица, занятость, работники, рынок труда, трудовая дискриминация

\section{Лабусов Максим Владимирович \\ Студент \\ Финансовый университет при Правительстве РФ 2. Москва, Ленинградский $n p-m, 49$}

\begin{abstract}
Unemployment is one of the most significant social and economic phenomena in the modern market economy. In most cases it is viewed as a negative fact. For the confirmation of this statement it's necessary to realize the sense and the peculiarities of the actual manifestation of unemployment. This will help to understand this economic and social phenomenon in the right way as well as to determine the further directions of its research
\end{abstract}

Key words: unemployment, occupation, employees, labour market, labour discrimination

\author{
Labusov Maksim Vladimirovich \\ Student \\ Financial University under the Government of the \\ Russian Federation \\ Moscow, Leningradskiy pr., 49
}

В современной рыночной экономике безработица является одним из наиболее значимых социально-экономических явлений. Вместе с тем в подавляющем большинстве случаев она рассматривается как сугубо негативное явление. Этот подход основан на преимущественном принятии во внимание негативных последствий безработицы, таких как ухудшение уровня жизни безработных граждан, усиление социальной нестабильности, недопроизводстве ВНП. Однако более точный анализ безработицы требует рассмотрения большего числа её аспектов.

Предметом моего исследования в рамках данной работы станет содержание безработицы как социального явления и социального процесса. Целью моего исследования в рамках данной работы станет углублённый анализ социальных и экономических аспектов безработицы и, как следствие, формирование собственного взгляда на определение дальнейших направлений исследования данного общественного феномена. В ходе своей работы я постараюсь следующие взаимосвязанные задачи: 
- чётко сформулировать основные понятия, рассматриваемые в моей работе;

- определить сущность, причины возникновения, социальную структуру и особенности безработицы;

- проанализировать меры, применяемые в рамках государственной политики занятости с целью снижения безработицы;

- изучить литературные источники по данной теме.

Для того чтобы начать исследование особенностей безработицы и связанных с ней процессов, необходимо сначала дать чёткое определение самого понятия безработицы.

Безработица - это несоответствие на рынке труда, при котором часть экономически активного населения страны, которая может и желает работать, не может найти работу. Данное несоответствие может носить как количественный, так и качественный характер.

В российской и международной практике определения безработного отличаются друг от друга. По методологии Международной организации труда (MOT) «безработным считается тот, кто в настоящий момент не имеет работы, ищет её, готов к ней приступить и не имеет других источников дохода, кроме заработной платы в сфере оплачиваемой занятости» [1, с. 84]. Согласно российскому законодательству «безработными признаются трудоспособные граждане, которые не имеют работы и заработка, зарегистрированы в органах службы занятости в целях поиска подходящей работы, ищут её и готовы приступить к ней в отчётном периоде» [7].

В Российской федерации подсчёт безработных определяется по методологии МОТ и на основании закона «О занятости населения в Российской Федерации». Эти методики также отличаются между собой. Согласно методике МОТ сведения о безработных собираются в результате выборочных обследований и опросов населения в возрасте от 15 до 72 лет. Эту процедуру в нашей стране осуществляет Государственный комитет по статистике. В соответствии с законом «О занятости населения в Российской Федерации» для регистрации гражданина в качестве безработного он должен состоять на учёте в органах службы занятости. В связи с такими различиями в методике подсчёта фактические данные о количестве безработных в нашей стране на отчётную дату, рассчитанные указанными способами, существенно разнятся: в службе занятости регистрируется только часть безработных граждан, находящихся в поиске работы. Ещё большее количество граждан, минуя службу занятости, ищут работу самостоятельно и не включаются в официальную статистику [4, с.59].Таких безработных можно выявить только на основании итогов соцопросов.

Таким образом, безработных (в частности, в нашей стране) можно разделить на 3 группы:

- лица, обратившиеся в поисках работы в службу занятости и официально признанные в качестве безработных (статусные безработные);

- лица, обратившиеся в поисках работы в службу занятости, но не признанные официально в качестве безработных; 
- лица, ищущие работы самостоятельно и не учитываемые в качестве безработных официальной статистикой (нестатусные безработные).

Под продолжительностью безработицы понимается период времени, который безработный затрачивает на поиски работы, используя все имеющиеся у него для этого возможности.

На основе приведённых фактов можно сделать вывод о том, что официальный уровень безработицы в России может быть недостаточно точным из-за недостатков учёта. В связи с этим основной методикой для подсчёта числа безработных в нашей стране служит методология МOT, тогда как данные, полученные из отчётности службы занятости (методика на основе закона «О занятости населения в Российской Федерации»), публикуются как справочные (дополнительные).

Прежде чем выявить и проанализировать причины безработицы, необходимо заметить, что безработица как социально - экономическое явление возникла и развивалась вместе с возникновением и дальнейшим развитием капиталистической (позже рыночной) экономики. Ни в каком другом обществе (рабовладельческом, феодальном, социалистическом) безработицы (формально) не существовало.

Поэтому первой и наиболее общей и часто выделяемой причиной безработицы является сама сущность рыночной экономической системы. В рыночной экономике безработица вызывается объективно действующим механизмом рыночного саморегулирования и конкуренцией, а потребность в рабочей силе определяется интересами обогащения и выживания предпринимателя. Это утверждение довольно очевидно и проверяемо на практике, ведь каждый предприниматель стремится выжить в конкурентной борьбе и сохранить занимаемую его фирмой долю рынка. Но, несмотря на все старания предпринимателей, банкротства являются нормальным явлением для рыночной экономики. Банкротство фирмы неизбежно означает увольнение всех работников, которые таким образом становятся безработными.

Второй причиной безработицы является технологический прогресс. Эта причины безработицы преимущественно выделяется и детально характеризуется в западной литературе. С течением времени и движением НТП машины и оборудование становятся все более производительными и дешёвыми, постепенно заменяя ручной труд. Теперь роль человека на производствах, где в качестве средств производства используются машины, сводится лишь к программированию и контролю их деятельности, что, безусловно, требует меньших по количеству трудовых ресурсов.

Третьей причиной безработицы принято считать затоваривание. Эта теория безработицы была преимущественно развита представителями кейнсианства. Дж. Кейнс, основатель кейнсианской экономической школы, считал, что люди обладают склонностью к сбережениям из-за нестабильности и циклических колебаний рыночной экономики. Высокая деловая активность, по мнению Кейнса, ведёт к росту числа произведённых товаров, которые из-за излишней бережливости не приобретаются людьми. Это постепенно приводит к накоплению нереализованной товарной продукции, т.е. затовариванию. За- 
товаривание в свою очередь постепенно подводит фирму к грани банкротства. Чтобы сохранить фирму, предпринимателю приходится снижать численность занятых у него работников посредством увольнений, т. е. увеличивать тем самым число безработных. Чтобы предотвратить затоваривание, спрос, по мнению Кейнса, должен быть «эффективным», т.е. таким, «чтобы люди своими денежными доходами оплачивали предлагаемые на рынке товары» [4, c.64].

Четвёртой причиной безработицы считается добровольное оставление места работы по каким-либо причинам.

Причины безработицы существенно обуславливают разновидности безработицы. К основным видам безработицы относятся:

Фрикционная безработица - безработица, вызванная самостоятельными действиями работников, связанными со сменой места жительства, получением образования, переходом на более интересную или высокооплачиваемую работу и т. д. Этот вид безработицы носит краткосрочный и неизбежный характер, т.к. работники часто ищут новое место приложения своего труда в связи с желанием изменить свой социальный статус или стать членом новой социальной группы. Такой вид безработицы считается благоприятным для экономики, т.к. «её результатом является повышение благосостояния граждан и более рациональное распределение трудовых ресурсов» [2, с.137].

Структурная безработица - безработица, вызванная несоответствием структуры спроса и предложением рабочей силы. Структурная безработица связана с изменением технологического уклада в экономике, в результате которого спрос на продукцию определённых производств падает, а сами эти производства или виды работ становятся устаревшими. В связи с невозможностью быстро осуществить переподготовку работников на новые виды производств возникает несоответствие между структурой спроса и предложения труда. Ввиду этого количество безработных увеличивается. Структурная безработица носит, как правило, затяжной и негативный характер, т.к. она непосредственно влияет на маргинализацию и люмпенизацию общества, но в то же время она, как и фрикционная безработица, неизбежна в связи с постоянным движением НТП.

Циклическая безработица - безработица, связанная со снижением объёмов производств и деловой активности на фазах спада и депрессии экономического цикла. Во время спада или кризиса в экономике совокупный спрос на товары и услуги неуклонно падает, вызывая тем самым сокращение объёмов производств, что в свою очередь порождает снижение уровня занятости и рост численности безработных. В зависимости от характера спада и типа экономического цикла продолжительность циклической безработицы может меняться, однако в подавляющем большинстве случаев она носит характер продолжительной. Циклическую безработицу также можно охарактеризовать как негативную, она непосредственно влияет на маргинализацию общества.

Скрытая безработица - безработица, при которой часть работников формально числится в качестве таковых на предприятии, но фактически там не работает. Скрытая безработица приобретает наибольшие масштабы в периоды проведения экономических реформ и существенного изменения условий 
функционирования бизнеса. Она может быть вызвана переходом от одной экономической системе к другой или нарушением функционирования рыночных механизмов. Экономической предпосылкой скрытой безработицы является падение реальной заработной платы. В экономическом аспекте структурная безработица связана с низкой производительностью труда, падением общей эффективности производства и снижением заработной платы. В условиях такого рода безработицы часть работников получает об общества больше, чем создаёт для него. Однако в целом структурная безработица носит двойственный характер: несмотря на создание препятствий для осуществления эффективного производства и повышения его результативности, она в то же время служит «социальным амортизатором», который не даёт уровню жизни трудящегося опуститься ниже определённого (порогового) значения, значительно нивелирует деструктивные последствия безработицы как для индивида, так и для всего общества.

Институциональная безработица - безработица, связанная с недостаточно эффективной организацией существующего рынка труда. При институциональной безработице безработные не обладают всей необходимой для трудоустройства информацией вследствие нескоординированной деятельности службы занятости или слабого трудового законодательства и поэтому долго не могут найти себе работу. К примеру, в России одним из аспектов, влияющих на достаточно весомый уровень институциональной безработицы, является отсутствие закона об обязательной регистрации свободных рабочих мест. Это ведёт к снижению гибкость рынка труда и росту уровня институциональной безработицы.

Добровольная безработица - безработица, которая вызвана отсутствием у человека стимулов к работе. Её не следует путать с фрикционной безработицей, т.к. при добровольной безработице человек почти никак не пытается найти себе официальную работу. Отсутствие желания работать может быть вызвано определёнными психологическими установками, ограниченными потребностями, стремлением к независимости, достаточным уровнем содержания со стороны супруга или членов семьи, а также необходимостью вести домашнее хозяйство.

Застойная безработица - безработица, характеризующаяся особенно высокой продолжительностью. Этот вид безработицы затрагивает особенно устойчивый слой безработных: нищих, бродяг, потерявших всякую надежду на работу. Застойная безработица крайне опасна как для индивида, так и для всего общества.

В социальном аспекте выделяют ещё несколько разновидностей безработицы, связанных с половозрастными характеристиками безработных:

Женская безработица - разновидность безработицы, связанная с особенностями женской рабочей силы и положением женщины на рынке труда. Женская безработица обусловлена особой ролью женщин в воспитании детей и ведении домашнего хозяйства. «Это является основной причиной того, что женщины рабочих профессий имеют, как правило, менее высокий по сравнению с мужчинами уровень квалификации» [4, с.71]. Необходимо отметить, что не- 
смотря на меньший уровень занятости у женщин, чем у мужчин, у женщин более низкий по сравнению с мужчинами уровень безработицы. Это связано с вышеупомянутыми особенностями роли женщины в семье. На современном рынке труда женщины подвергаются социальной дискриминации, что зачастую выражает в первоочерёдном, часто необоснованном увольнении женщин. В связи с этим на национальном (в том числе в России) и международном уровнях был принят ряд нормативно - правовых актов, направленных на защиту трудящихся женщин и искоренению различных форм дискриминации по отношению к ним.

Молодёжная безработица - разновидность безработицы, связанная с особенностями использования труда социально - возрастной группы от 16 до 28 лет. Уровень безработицы у молодёжи выше, чем у старших рабочих. Это связано с первым для индивида выходом на рынок труда, стремлением работодателя нанять человека со стажем работы, инфантилизацией и попустительским отношением к работе со стороны молодого поколения. В то же время в трудовом аспекте молодёжь является одной из незащищённых социальных групп населения. Именно поэтому на современном этапе компетентные органы оказывают содействие в поиске работы для молодёжи. Это выражается в организации курсов профессиональной ориентации, ярмарок вакансий, стажировок. На отдельных профессиях для молодёжи предусмотрены определённые социальные премии и доплаты к заработной плате.

Все вышеприведённые виды безработицы помогают рассматривать этот феномен не только с экономической, но и с социальной точки зрения, характеризуют безработицу как непрерывный социальный процесс.

В рамках анализа безработицы как социального явления необходимо рассмотреть её половозрастную структуру. Это будет сделано на примере нашей страны. В начале 2000- х г. основную массу безработных в нашей стране составляли женщины и лица предпенсионного возраста. По своей образовательной структуре это были лица с высшим и средним специальным образованием. Но затем в некоторых субъектах РФ в структуре безработных стала расти доля мужчин среднего возраста и молодёжи. В профессиональном аспекте это были в основном низкоквалифицированные трудовые ресурсы. На сегодняшний день по структуре безработицы в том или ином регионе можно сделать вывод о масштабности этого явления и состоянии региональных и местных рынков труда. В регионах, где в половозрастной структуре безработицы преобладают люди предпенсионного возраста (чаще это могут быть даже мужчины, нежели женщины), можно сделать вывод об удовлетворительном состоянии рынка труда. В тех же регионах, где в структуре безработных наибольший удельный вес имеют граждане в возрасте от 16 до 28 лет и граждане с низким и средним уровнем образования, проблема безработицы особенно актуальна. Это свидетельствует о недостаточно эффективном функционировании рынков труда в тех регионах [6]. Динамику изменения структуры безработных в России в конце 1990 - х - начале 2000- х годов можно проиллюстрировать таблицей: 
Таблица 1. Динамика изменений в структуре российских безработных в 1992 - 2009 г2.

\begin{tabular}{|l|c|c|c|c|c|}
\hline \multicolumn{1}{|c|}{ Год } & 1992 & 1999 & 2000 & 2002 & 2009 \\
\hline $\begin{array}{l}\text { Безработные всего, млн. } \\
\text { человек }\end{array}$ & 3,9 & 9,1 & 7,0 & 6,2 & 6,2 \\
\hline $\begin{array}{l}\text { Студенты, учащиеся, } \\
\text { пенсионеры, тыс. чел., \% }\end{array}$ & $714,6 / 18,4$ & $967,4 / 10,6$ & $711,2 / 10,2$ & $635,0 / 10,3$ & $660,4 / 10,7$ \\
\hline Женщины, млн. чел.,\% & $1,9 / 47,7$ & $4,3 / 47,2$ & $2,9 / 45,9$ & $2,8 / 46,0$ & $2,9 / 47,7$ \\
\hline $\begin{array}{l}\text { Сельские жители, млн. } \\
\text { чел., \% }\end{array}$ & $0,651 / 16,8$ & $2,2 / 24,5$ & $1,8 / 26,5$ & $1,9 / 31,5$ & $1,9 / 32,4$ \\
\hline $\begin{array}{l}\text { Соотношение статусных } \\
\text { и нестатусных безра- } \\
\text { ботных,\% }\end{array}$ & 14,9 & 13,9 & 14,8 & 24,4 & 34,8 \\
\hline
\end{tabular}

* Источник: Силласте Г.Г. Экономическая социология: учебное пособие // М.: ИНФРА-М, 2012, С.141

Как уже было указано, последствия безработицы носят в основном негативный характер. К негативным последствиям безработицы на уровне индивида относят:

- Потеря дохода или части дохода;

- Серьёзная психологическая травма;

- Потеря профессиональных навыков и квалификации;

- Потеря уверенности в себе, рост вероятности возникновения стресса и депрессии;

- Рост вероятности возникновения антисоциального поведения

К негативным последствиям безработицы на уровне общества относят:

- Недопроизводство ВНП и недополучение НД;

- Замедление экономического развития общества;

- Рост уровня различных заболеваний;

- Рост социальной напряжённости: преступности, бродяжничества и т.д.;

Для нивелирования негативных эффектов безработицы государство осуществляет политику занятости населения. Она может быть разделена на пассивную и активную. Рассмотрим основные методы, применяемые в рамках этих 2 направлений.

В рамках пассивной политики занятости государство представляет безработным ряд следующих социальных гарантий:

- Выплату пособий по безработице;

- Оказание материальной помощи (выплата ставки) в условиях безработицы (только для лиц, зарегистрированных на бирже труда и делавших в установленное время взносы в фонд по безработице);

- Поддержание уровня прожиточного минимума.

Активная политика занятости направлена на содействие безработным в получении новой работы. Её основные направления в нашей стране указаны в законе «О занятости населения в Российской Федерации»:

- Развитие рынков труда и человеческих ресурсов, повышение их мобильности; 
- Обеспечение равных возможностей в реализации права на труд и выбор занятости гражданами вне зависимости от пола, возраста, национальности и отношения к религии;

- Создание условий, обеспечивающих достойную жизнь и свободное развитие человека;

- Координация деятельности в области занятости населения;

- Координация деятельности государственных органов, профсоюзов, иных представительных органов работников и работодателей в разработке и реализации мер по обеспечению занятости населения и контролю над ними;

- Поощрение работодателей, создающих новые рабочие места, особенно для социально незащищённых групп граждан;

- Обеспечение занятости в местах проживания коренного населения и национальных меньшинств с учётом их национальных и культурных особенностей;

- Международное сотрудничество в решении проблем занятости населения.

Таким образом, государственная политика занятости населения является основным инструментом борьбы с безработицей в стране. В нём проявляется социальное взаимодействие государства и общества, направленное на решение существующих проблем, вызванных безработицей.

На основе проведённого анализа можно сделать вывод о том, что безработица является многосторонним социально - экономическим явлением и для её анализа необходимо принимать во внимание множество факторов, которые были приведены в данной работе. Выявление влияния различных особенностей безработицы по отдельности и в совокупности необходимо для того, чтобы:

Преодолеть поверхностное представление об ущербе от безработицы;

Правильно учитывать издержки безработицы в структуре государственного бюджета;

- Определять наиболее важные направления политики занятости в экономической и социальной политике государства;

- Повысить эффективность работы служб занятости населения;

Правильно измерять и определять структуру безработицы и разрабатывать на основе этой структуры методики оценки социального ущерба от безработицы для работника, работодателя, компании, отрасли производства.

В социальном аспекте безработицу необходимо рассматривать как процесс (социальный) изменения работниками своего состояния на рынке труда, а также процесс изменений, происходящих в функционировании социальных институтов и организаций, осуществляющих свою деятельность в сфере обеспечения занятости населения (бирж труда). Феномен безработицы также необходимо рассматривать как социальное явление, являющегося результатом социального взаимодействия, т.е. взаимного влияния друг на друга, государства и его институтов в сфере занятости, работодателей и наёмных работников. Деятельность всех этих субъектов направлена на достижение стабильного оптимального для экономики и общества уровня безработицы (под таким 
уровнем часто понимается естественный уровень безработицы - сумма (в \%) уровней фрикционной и структурной видов безработицы).

Дальнейшие социологические исследования в области безработицы должны быть направлены на изучение её влияния на ценностные и поведенческие ориентации занятых и безработных; на исследование влияния особенностей безработицы на деятельность рынков труда и разработку методов повышения эффективности их функционирования; на определение степени готовности безработных к переквалификации и определение наиболее подходящих типов профессий для каждой из групп безработных; на определение влияния безработицы на степень маргинализации и люмпенизации общества и поиск потенциальных путей снижения этого воздействия; на определение оптимальных пропорций между мерами пассивной и активной политики занятости в рамках государственной политики содействия занятости населения.

\section{Список литературы:}

1. Адамчук В.В. Экономика труда. М.: Финстатинформ, 2014. 432 с.

2. Грязнова А.Г., Думная Н.Н. Макроэкономика. Теория и российская практика. М.: КНОРУС, 2007. 688 c.

3. Остапенко Ю.М. Экономика труда: учебное пособие. М.: ИНФРА-М, 2006. 268 c.

4. Павленков В.А. Рынок труда. Занятость. Безработица. М.: Изд-во МГУ, 2004. 368 c.

5. Силласте Г.Г. Экономическая социология: учебное пособие. М.: ИНФРА-М, 2012. 480 c.

6. Соколова Г.Н. Структура занятости и безработица: Проблемы и тенденции // Экономика и жизнь. 2008. №1.

7. Закон РФ от 19.04.1991 № 1032 - 1 (ред. от 02.07.2013) «О занятости населения в Российской Федерации».

(C) 2015, Лабусов М.В.

Безработица как социальное явление и социальный процесс
(C) 2015, Labusov M.V.

Unemployment as a social phenomenon and a social process 


\title{
Радько О.Ю.
}

\section{Автоматизация бизнес-процессов в общей системе управления финансово-кредитным предприятием}

\author{
Radko O.Yu. \\ Automatization of business processes in the generall \\ management system of financial and credit organization
}

В данной статье рассмотрены теоретические аспекты повышения эффективности бизнеспроцессов кредитно-финансового предприятия посредством внедрения автоматизированной информационной системы

Ключевые слова: бизнес-процесс, кредитнофинансовое предприятие, автоматизированная информационная система

\section{Радько Оксана Юрьевна}

Кандидат педагогических наук, доцент Тамбовский государственный технический университет

г. Тамбов, ул. Советская, 106
This article describes the theoretical aspects of improving the efficiency of business processes of credit and financial companies through the implementation of an automated information system

Key words: business process credit and financial organisation, automated information system

Radko Oksana Yurievna

Candidate of Pedagogic Sciences, Associate Professor Tambov state technical university

Tambov, Sovetskaya st., 106

В современных экономических условиях обеспечение конкурентоспособности предприятия является обязательным условием его долгосрочного функционирования на рынке финансовых услуг. Повышение конкурентоспособности всех коммерческих предприятий в большой степени определяется рациональной организацией бизнес-процессов. Рационально построенный бизнес-процесс представляет собой процесс, предусматривающий достижение поставленной цели с минимальными затратами.

При изменении условий работы предприятия, принятая в нем система бизнес-процессов может стать неэффективной, что требует некоторого целенаправленного изменения этой системы, или оптимизации бизнес-процессов. По мнению Э.А. Уткина [1, с. 78], оптимизация - это фундаментальное переосмысление бизнес-процессов компании для достижения коренных улучшений в основных актуальных показателях их деятельности: стоимость, качество, услуги и темпы. Оптимизация представляет собой изменения в структуре деятельности коммерческого предприятия, направленные на повышение эффективности существующих бизнес-процессов. Как показывает практика, оптимизация бизнес-процессов требуется, когда у предприятия есть ряд проблем связанных с постепенным накапливанием изменений в непосредственной дея- 
тельности предприятия или в окружающей бизнес-среде, а так же с кардинальными управленческими решениями (например, расширение или сокращение направлений деятельности).

Оптимизация бизнес-процессов необходима, при возникновении следующих проблем:

- замедление реагирования управленческой структуры на быстрое повышение эффективности предприятия;

- отсутствие прозрачности и явности в вопросах ответственности и полномочий сотрудников;

- дублирование производственных или управленческих функций разными подразделениями;

- отсутствие единой стандартизации бизнес-процессов;

- непривлекательность предприятия для инвесторов, ввиду отсутствия

четкой и прозрачной структуры бизнес-процессов;

- возникновение желания у руководства сделать управление (капиталом, человеческими ресурсами, проектами) более эффективным, опираясь на опыт ведущих успешных предприятий;

- необходимость корректировки бизнес процессов в условиях меняющихся экономических условий.

Перед тем как начинать работу по оптимизации, необходимо описать существующие в компании бизнес-процессы «как есть» (создать их модели). Модель «как есть» может создаваться на основе изучения документации (должностных инструкций, положений о предприятии, приказов, отчетов), анкетирования и опроса служащих предприятия и других источников. С помощью синтаксического анализа модели можно легко обнаружить «бесполезные» (не имеющие выхода), «неуправляемые» (не имеющие управления) и «простаивающие» функции. Более тонкий анализ позволяет выявить дублирующие, избыточные или неэффективные функции. Модель дает целостное представление о работе предприятия как системы в целом и возможность понять взаимосвязи всех его составляющих. После построения этой модели, как правило, выясняется, что обработка информации и использование ресурсов неэффективны, важная информация не доходит до соответствующего рабочего места. Признаком неэффективности организации работ является, например, отсутствие обратных связей по входу и управлению для важных функций. На рис. 1 представлен пример модели «как есть», составленной в графической нотации Integration Definition for Function Modeling (IDEF0).

Описания модели «как есть» должны быть четкими, однозначными и затрагивать уровень, на котором видна конкретная работа сотрудников. Необходимо анализировать каждую часть бизнес-процесса, выполняемую конкретным исполнителем. Оценивая ее, надо проверять, к каким результатам приводит правильное выполнение, какие данные или материалы исполнитель получает в итоге, степень оптимальности его действий, а также продолжительность выполнения процедуры. Результатами оценки оптимальности должны стать выявленные недостатки в процессе или группе процессов. 


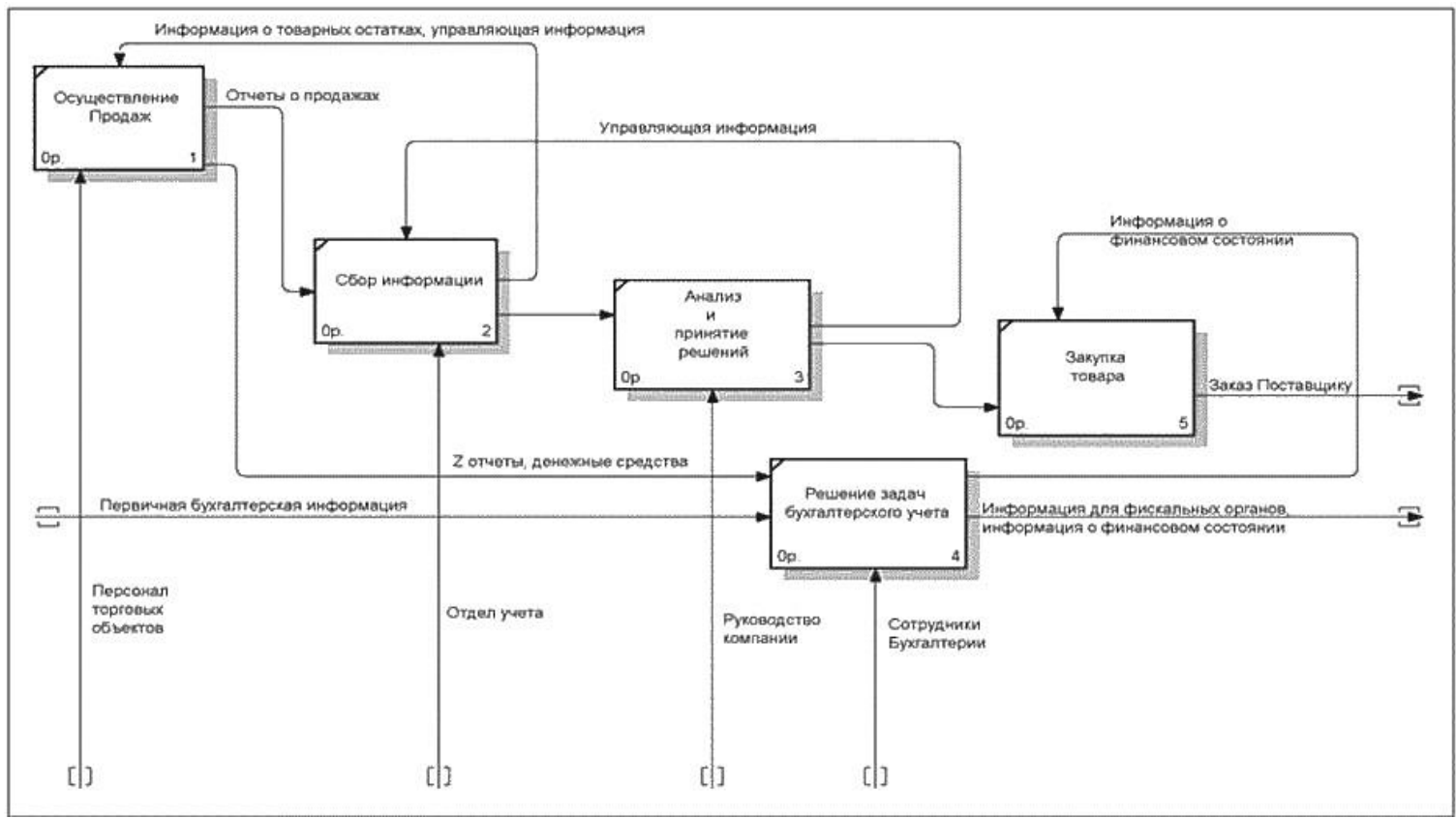

Рис. 1. Пример модели «как есть» для кредитно-финансового предприятия

Так же необходимо разработать предложения по исправлению выявленных недостатков, перестроить модель процесса (модель «как будет»), учитывая разработанные предложения, пересмотреть действия исполнителей и кандидатуры самих исполнителей. Очень важной является оценка возможных ухудшений от предлагаемых исправлений недостатков в других процедурах процесса, в том числе и возможную неготовность сотрудников.

Рассмотрим несколько способов эффективной оптимизации бизнеспроцессов.

1. Сокращение (полная ликвидация) избыточных бизнес-процессов (функций).

Данный способ заключается в выявлении и ликвидации деятельности, результат выполнения которой никак не влияет на достижение целей компании. В этом случае оптимизация бизнес-процессов проводится в короткие сроки, без глубокого погружения в детали. Сокращение издержек при применении данного случая может составить 5-10\%.

2. Концентрированное улучшение бизнес-процессов.

Данный способ подразумевает проведение комплекса мероприятий, включающих, не только сокращение избыточных бизнес-процессов (функций), но и корректировку уже отстроенных и работающих процессов. В этом случае основными направлениями действий могут быть стандартизация, автоматизация, более широкое применение информационных технологий и т.д. Оптимизация бизнес-процессов проводится в течение 4-5 месяцев, с выборочным погружением в детали процессов предприятия. Сокращение издержек может составить $15-20 \%$.

3. Реинжиниринг (перепроектирование) бизнес-процессов.

Способ представляющий собой принципиальное изменение состава и способа выполнения существующих бизнес- процессов (функций), вплоть до их перепроектирования. Данный способ применяется к процессам, относящимся к 
основной деятельности. В данном случае оптимизация бизнес-процессов проводится в течение 6 и более месяцев, с глубоким погружением в детали. Сокращение издержек может составить 20-30\% и более. Отметим, что применение реинжиниринга сопряжено с серьезными рисками: потерей части ключевых сотрудников, сбоями, связанными с переходом на новые методы работы и т.д.

В последнее время все большую популярность в качестве эффективного способа оптимизации бизнес-процессов предприятий приобретает внедрение автоматизированных систем управления класса ERP (Enterprise Resource Planning) которые призваны упростить управление всеми ресурсами предприятия и уменьшить влияние человеческого фактора на рабочий процесс.

ERP-системы - это компьютерные системы, созданные для обработки деловых операций предприятия и для содействия комплексному и оперативному планированию, производству и обслуживанию клиентов [2, с. 127].

Основными возможностями этих систем являются:

- планирование;

- учет;

- анализ;

- управление.

Внедрение ERP-системы на предприятии не только способствует повышению степени автоматизации отдельных процессов, но и проведению реинжиниринга самих этих процессов. В результате такого внедрения стандартизируется подавляющее большинство операций, значительно растет управляемость организации, повышается степень ее информационной открытости. Основными понятиями в структуре любой ERP-системы являются понятия модели объекта и процесса. Суть внедрения системы на предприятии состоит в установлении соответствия между этими параметрами системы и элементами и процессами реальной организации.

Взаимодействие с ERP-системой осуществляется путем ввода данных и получения отчетов. Ввод данных организуется таким образом, чтобы исключить любое дублирование и обеспечить должный уровень контроля над правильностью ввода для исключения возможных ошибок оператора. Выходные данные могут предоставляться как в виде стандартных отчетов, так и результатов специальных запросов пользователя. Для удобства использования отчеты размещаются в корпоративной или глобальной сети, а также интегрируются в различные пользовательские приложения.

Эволюция систем управления предприятием привела к появлению ERPсистем второго поколения - ERP II. Эти системы вобрали в себя множество дополнительных модулей по управлению различными ресурсами, такими как персонал, отношения с клиентами, управление знаниями и организация логистических потоков.

Очевидно, что ERP-системы в ближайшем будущем станут частью системы менеджмента любого предприятия, будь то небольшая торговая фирма или транснациональная корпорация. Популярность таких систем стремительно растет, а цена их внедрения и эксплуатации неуклонно падает. Уже в настоя- 
щий момент внедрение ERP-системы является оправданным шагом на пути повышения эффективности управления для любой компании.

Понятия модель, объект и процесс (МОП) являются ключевыми в структуре любой ERP-системы. Процесс конфигурирования ERP-системы состоит в выборе и отражении в системе моделей, объектов и процессов, используемых организацией.

B ERP-системах заложено несколько моделей, таких как, например, модель организационных структур в системе. Эти модели - отображение реального мира в системе, и их качество важно для отражения реальности. Например, модель организационных структур позволяет фиксировать информацию вплоть до буферного накопителя. И информация может быть объединена, начиная с буфера памяти, до уровня корпоративной группы. Такие возможности дают не только пользу, но и требуют затрат. С одной стороны, они могут обеспечить системе определенный уровень детализации организации, необходимый для моделирования фирмы. С другой стороны, если модель фирмы меняется, она должна быть изменена и в системе. В результате, если модели меняются часто, это обходится довольно дорого.

Объект можно определить как интерфейс между «внутренней» средой содержанием и организацией самого объекта - и «внешней» средой - окружением, в котором он функционирует. Внутренняя среда - это компьютерная программа, а внешняя - это мир, в котором функционирует система. Например, под таким объектом предприятия, как «документ», обычно понимается счет. Кроме того, объектами также являются реализации моделей (в форме перечня счетов, списков производителей, списков продукции и т.д.). Объекты предприятия известные как документы генерируются системами в качестве выходных данных (например, счета) или используются ими в качестве входных данных (заказы клиентов). Объекты предприятия, являющиеся реализациями моделей (например, списки производителей), обеспечивают структуру производственных систем.

Процессы - это потоки деятельности и информации, необходимые для выполнения определенной задачи или группы задач. Обычно организации должны выбирать процессы, соответствующие их потребностям, из набора процессов, содержащихся в ERP-системе [3, с. 88]. Поскольку, в принципе, существует множество способов выполнения задачи или групп задач, каждый из процессов не является единственно возможным. А так как они не являются единственно возможными, ожидается, что одни процессы будут работать лучше, чем другие. В рамках ERP-систем существуют многочисленные процессы, охватывающие несколько функций.

Процесс управления заказами SAP. Этот процесс отображается в многочисленных модулях SAP, интегрированных между собой. В традиционной функционально-ориентированной системе, напротив, существовало бы, по меньшей мере, четыре различные системы (товарооборот и распределение, производственное планирование, управление материалами и финансы), которые не были бы интегрированы. И обмен информацией между ними производился бы вручную, если бы вообще производился. 
Внедрение процессов системами планирования ресурсов предприятий, в конечном счете, требует многих решений, которые обычно принимаются группой внедрения. Среди этих решений такие, как, например, кому выдать кредит и кому отказать, или, когда предложить скидки и кто их должен получить.

До внедрения ERP-систем фирмы в целом не использовали общие и глобальные модели, объекты и процессы (МOПы). Однако внедрение ЕRР-систем обычно требует общих МОПов по нескольким причинам: требования системы, обслуживание клиентов, управление процессами, общекорпоративная БД, создание ценности и снижение расходов.

Обычно компании создают набор стандартов, выбирая из существующих у них МОПов (найденных в различных подразделениях), лучших практик, предоставленных консультантами и ERP-системой, а также используя смешанные подходы. К сожалению, чаще всего не понятно, какой набор объектов и стандартов должен быть принят, особенно из-за того, что при любом выборе одни подразделения получат большую выгоду, чем другие. Стандартизация МОПов может быть довольно широкой, а подразделениям может быть разрешено выбрать только около 1\% МОПов.

Отметим, что в основе ERP-систем лежит принцип создания единого хранилища данных, содержащего всю корпоративную бизнес-информацию и обеспечивающего одновременный доступ к ней сотрудников предприятия, наделенных соответствующими полномочиями. В ходе проекта внедрения ERP-системы оптимизация ключевых бизнес-процессов происходит за счет автоматизация процессов, минимизации рутинных операций, снижение нагрузки на пользователя системы и предоставление достоверной информации для принятия решения человеком. Внедрение подобных систем не может решить всех проблем, но позволит сосредоточиться не решении наиболее приоритетных вопросов.

\section{Список литературы:}

1. Уткин В.Б. Информационные системы и технологии в экономике. М.: ЮНИТИ-ДАНА, 2003. 316 с.

2. Обухов И.А., Гайфуллин Б.Н. Автоматизация систем управления предприятиями стандарта ERP-MRPII. М.: Интерфейс-пресс, 2001. 247 с.

3. О'Лири Д. ЕRР-системы: выбор, внедрение, эксплуатация. Современное планирование и управление ресурсами предприятия. М.: Вершина, 2011.290 с.

4. Денисова А.Л., Дюженкова Н.В. Организация коммерческой деятельности: управление запасами.

Тамбов: Тамб. гос. техн. ун-т, 2007. 80 c.

(C) 2015, Радько О.Ю.

Автоматизация бизнес-процессов в общей системе управления финансово-кредитным предприятием
(C) 2015, Radko O.Yu.

Automatization of business processes in the generall management system of financial and credit organization 


\title{
Силантьева М.К. Порто-франко, как инструмент развития рыбной промышленности Приморского края
}

\author{
Silantieva M.K. \\ Porto Franco - instrument of development \\ fishing industry of Primorye
}

Развитие рыбохозяйственного комплекса приморского края, в виду реализации проекта свободного порта Владивосток

Ключевые слова: Порто-Франко, рыбохозяйственный комплекс, Владивосток

\section{Силантьева Мария Константиновна}

Магистрант, Экономист по планированию 1 категории

44 ремонтный завод радиотехнического вооружения

г. Владивосток, ул. Борисенко, 100 Д
Development fishery complex of Primorye, since the project free port of Vladivostok

Key words: Porto Franco, fishing industry, Vladivostok

\section{Silantieva Mariya Konstantinovna}

Undergraduate, Economist

44 Repair plant electronic weapons

Vladivostok, Borisenko st, 100 D

«Ресурсы и государства, и частного бизнеса должны идти на развитие, на достижение стратегических целей. Например, таких, как подъем Сибири и Дальнего Востока. Это наш национальный приоритет на весь XXI век. Задачи, которые предстоит решить, беспрецедентны по масштабу, а значит и наши шаги должны быть нестандартными» (Владимир Владимирович Путин, президент Российской Федерации)

«Владивосток далеко, но, ведь, это город-то нашенский» (Владимир Ильич Ленин, выдающийся российский революционер)

Первые лица государства во все времена понимали важность Дальнего Востока и Приморского края в укреплении политических и экономических интересов России в Азиатско-Тихоокеанском регионе. Но отдаленность района не позволяла в полной мере сосредоточиться на внедрении перспективных экономических проектов. Только в начале XXI века обновленный политический курс правительства Российской Федерации в полной мере захватил развитие всех социально-экономических сторон Приморского края.

Первым крупным шагом тому было проведение Азиатско-Тихоокеанского Экономического Саммита 2012 года (АТЭС 2012) в г. Владивостоке. Были привлечены крупные «финансовые вливания» в развитие инфраструктуры края, проведение множества социальных программ и т.д. Проведение саммита стало 
толчком в развитии бизнеса Приморского края в целом, в том числе рыбной отрасли региона.

Порто-франко - особая зона на территории порта обладающая правом беспошлинного ввоза и вывоза товаров.

Создание подобных экономических зон является одним из самых перспективных способов реализации стратегических задач развития Сибири и Дальнего Востока, которые президент Российской Федерации Владимир Владимирович Путин поставил перед правительством еще в начале своей работы на посту главы государства.

Представители рыбохозяйственного комплекса активно принимают участие в обсуждении деталей законопроекта. Одними из основных вопросов остающихся открытым является модернизация портового, холодильного оборудования, а также обновление рыбодобывающего флота.

Как отметил президент Ассоциации рыбохозяйственных предприятий Приморья Георгий Мартынов на проходившем во Владивостоке заседании Комиссии Российского Союза Промышленников и Предпринимателей по рыбному хозяйству и аквакльтуре, развитие инфраструктуры рыбных портовых терминалов - залог увеличения поставок рыбопродукции на внутренний рынок страны.

Проект порто-франко Владивосток планирует объединить в себе еще и порты юга Приморского края - это позволит создать конкурентную предпринимательскую среду в масштабах всего региона.

Порт должен стать опережающим свое время. При этом ему придется конкурировать с Шанхаем и Пусаном, имеющими развитую суперсовременную портовую инфраструктуру. Поэтому самым разумным шагом будет ориентация на успешный зарубежный опыт. Ведь создание свободного порта - это не только модернизация самого порта, а еще и развитие второстепенной вспомогательной инфраструктуры.

Ускорение и увеличение грузопотока через порт Владивосток непременно позволит рыбакам сократить время пребывания своего флота в порту, а как следствие ускорить освоение выделяемых квот.

Ассоциацией рыбохозяйственных предприятий Приморья было предложено полностью освободить портовиков от арендной платы и взамен обязать их ежегодно инвестировать эти средства в причальные гидротехнические сооружения. По их мнению привлечь дополнительные объемы рыбы в свободный порт можно путем освобождения рыбаков от уплаты НДС. Аналогичную льготу, на их взгляд, стоит распространить на грузовые операции и хранение рыбопродукции.

Уменьшение бюрократических проволочек связанных в первую очередь с обслуживанием судов, будет способствовать повышению конкурентоспособности российских рыбаков.

Создание полноценной функционирующей рабочей группы, включающей в себя представителей различных слоев рыбохозяйственного комплекса, позволит проводить детальный анализ всех вопросов связанных с развитием рыбного бизнеса в Приморском крае. 
Очевидно, что проект свободного порта Владивосток координальным образом решит огромный перечень вопросов и проблем, связанных с рыбным сегментом бизнеса в регионе. Только объединение усилий позволит улучшить условия работы предпринимателей, а государству, за счет автономности бизнеса и уменьшения финансовых дыр в бюджете, сосредоточиться на проведение социально значимых программ во всех регионах страны.

(C) 2015, Силантьева М.К.

Порто-франко, как инструмент развития рыбной промышленности Приморского края
(C) 2015, Silantieva M.K.

Porto Franco - instrument of development fishing industry of Primorye 


\title{
Сорина Е.И. Электронная система документооборота - E-invoicing
}

\author{
Sorina E.I. \\ Electronic document management system - E-invoicing
}

Электронная система документооборота Einvoicing, предоставляет собой дистанционное управление всеми документами обслуживания, позволяет общаться с сотрудниками банка, быстро обмениваться сообщениями, различными документами и просто предоставит всю нужную информацию об операции по счетам и остаткам Ключевые слова: электронный документооборот, дополнительные сервисы, электронная подпись, интернет-банкинг, мобильный-банкинг

\section{Сорина Екатерина Игоревна}

\section{Ассистент}

Тамбовский государственный технический университет

г. Тамбов, ул. Советская, 106

\begin{abstract}
Electronic document management system Einvoicing, provides remote management of all documents service allows you to communicate with Bank employees to quickly share messages, documents and just provide all the necessary information about account transactions and balances
\end{abstract}

Key words: electronic document flow, additional services, electronic signature, Internet banking, mobile banking

\author{
Sorina Ekaterina Igorevna \\ Assistant \\ Tambov state technical university \\ Tambov, Sovetskaya st., 106
}

В наш век электронных технологий документооборот на бумажных источниках почти исчерпал себя. На смену бумажным носителям пришли цифровые технологии. За рубежом огромный объем документации, который ведут и вырабатывают госучреждения, и коммерческие организации давно конвертирован в виртуальное пространство и получил название - E-invoicing. Цифровой способ хранения данных намного экономнее в сравнении с ведением документации обычным способом, да и иных преимуществ так же предостаточно у безбумажного документооборота. В наши дни эта перспективная технология появилась и в России [5].

В нашей стране уже больше года закрепили возможность переводить бумажную документацию в электронный вид законодательно. Последним документом из утвержденных для электронного оформления стало счет - фактура. Первой российской компанией по внедрению электронного документооборота на нашем рынке стал Сбербанк.

Сегодня услуги электронного документооборота E-invoicing уже не новость. Все чаще звучат словосочетания «электронный обмен данными», «дистанционные сервисы», «удаленный доступ к услугам». Почти два года назад Сбербанк своим клиентам и государственным учреждениям предоставил воз- 
можность перевода огромного объема бумажной документации на цифровые носители и в виртуальное пространство, запустив услугу E-invoicing.

Сбербанк проявил огромный интерес к показавшей себя с наилучшей стороны технологии на Западе, хотя в России она была почти неизвестной. Прежде всего, манили перспективы. Масштабы нашей страны, информационные технологии и иностранные компании, работающие на нашем рынке многие годы с E-invoicing, создают все условия для быстрого развития данной услуги в России [10, с. 22].

Основными достоинствами электронного документооборота это быстрый доступ получения документации, снижение различных ошибок и удобство их исправления, уменьшение затрат при хранении документов, высокая их сохранность, регулирование взаимоотношений с контрагентами, а так же благодаря бухгалтерским программам происходит уменьшение трудоемкости, снижаются расходы на почтовые пересылки.

Сбербанк России всегда внедряет самые передовые технологии в своих офисах, ведь он всегда нацелен на инновации. Он первым оценил перспективы электронного документооборота и незамедлительно предоставил данную услугу своим корпоративным клиентам. Юридическим лицам и индивидуальным предпринимателям предлагается система Интернет банкинга, но Сбербанк дает им виртуальное банковское безбумажное пространство, тем самым предоставляя услуги по электронной подписи, не посещая отделения [6, с. 235].

Клиенты могут вести обмен с контрагентами первичными документами в электронном виде внутри такой системы, когда сохраняется их юридическая сила. Электронный документооборот существенно оптимизирует бизнеспроцессы предприятий. Происходит их взаимодействие с налоговыми органами и друг с другом.

Для ряда компаний п.3 ст.80 Налогового кодекса установлена обязанность предоставлять в налоговые органы отчеты в электронном виде [4].

C 1 апреля 2015 года налогоплательщики обязаны включать в новую форму декларации по НДС сведения их книг продаж и покупок, а так же журнала учета полученных и выставленных счетов-фактур. Этот новый формат налоговой декларации по НДС сдается только в электронном виде. В разделе «Отчетность в госорганы» в системе E-invoicing существует сервис отправки нового формата налоговой декларации в ФНС.

Время в наши дни самой большой капитал в бизнесе, а с услугой Еinvoicing продуктивность всей компании может существенно возрасти.

Клиенты Сбербанка к предлагаемой услуге E-invoicing проявляют огромный интерес.

Более чем в 2 раза за последний год возросло предложение иных дополнительных сервисов для юридических лиц. Для физических лиц в рамках системы ДБО также происходит рост и расширяется предложение дополнительных сервисов [11]. 
Дополнительные сервисы в системах ДБО для юридических лиц

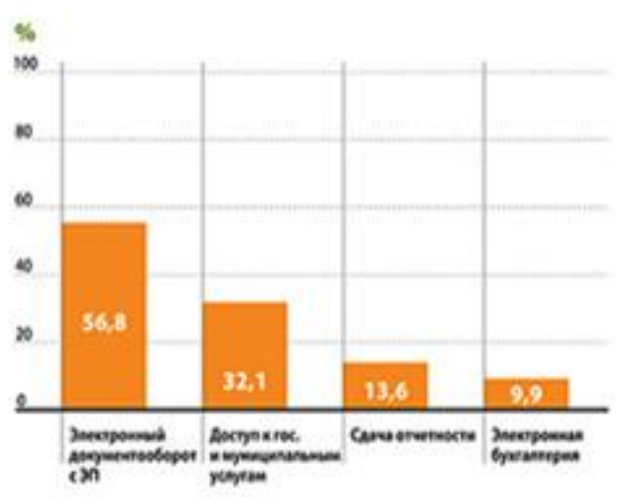

Дополнительные сервисы в системах дБО для физических лиц

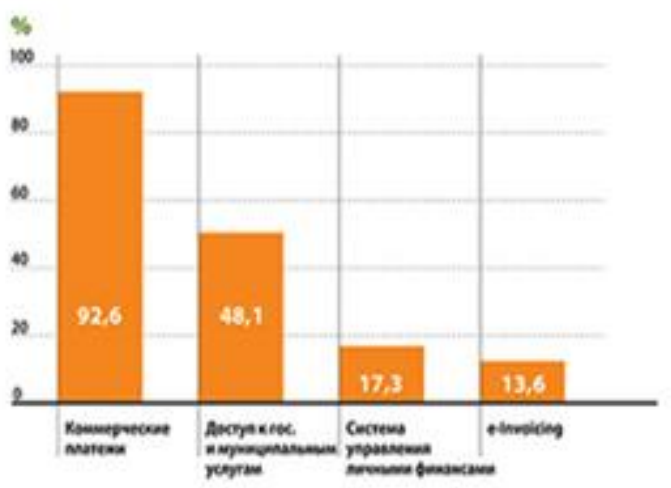

Рис. 1. Дополнительные сервисы в системах ДБО для юридических и физических лич

Из исследований видно, что в 81\% банков внедрены дополнительные сервисы для клиентов систем ДБО. Корпоративные клиенты имеют возможность проводить электронный документооборот с использованием электронной подписи - 56,8\%. Доступ к государственным и муниципальным услугам (оплата налогов, штрафов и др.) могут получить 32,1\%. Сдавать готовые отчеты в ФНС России, ПФР, Росстат - 13,6\%. Электронной бухгалтерией пользуются - 9,9\% клиентов [12].

Почти в 93\% случаев банки своим клиентам физическим лицам дают возможность проведения коммерческих платежей. Получение доступа к государственным и муниципальным услугам 48,1\%. В 17,3\% использование системы управления личными финансами, а оплаты счетов в системе ДБО 13,6\%.

Сбербанк в рамках системы «Бизнес Онлайн» запустил новую услугу «облачную» электронную подпись. Благодаря ей у клиента есть доступ к услугам электронного документооборота E-invoicing. При этом нет необходимости приобретать электронного ключа. А всего лишь достаточно пройти регистрацию в системе «Сбербанк Бизнес Онлайн». Необходимо заполнить заявление о выдаче «облачной» электронной подписи. Когда в течение трех дней придет смс-сообщение о выдаче электронной подписи клиент сможет в привычном ритме продолжить работу. «Облачная» электронная подпись отличается от обычной тем, что не требует специализированного программного обеспечения на компьютере. Ее хранение осуществляется на специальных ресурсах Удостоверяющего центра компании - партнера банка, имеет необходимую сертификацию ФСБ и Федеральной службы по техническому и экспортному контролю. Эта подпись разрешена к использованию при ведении электронного документооборота (в том числе передачи отчетности в контролирующие органы) [2].

«Сбербанк Бизнес Онлайн» это особый вид интернет-банкинга. В ней можно выбрать вкладку с названием E-invoicing и вам откроются все ее возможности. Если ваши партнеры уже подключены к системе, то вы без проблем сможете их обнаружить в меню интернет-банкинга [9, с. 398]. 
Так же имеется возможность подключения к E-invoicing, не имея расчетного счета в Сбербанке. Эта процедура не совсем логична, так как клиент не сможет пользоваться всеми преимуществами интернет-банкинга. Пример можно привести, если представить, что с одного телефона можно только звонить, а с другого только отправлять смс, это очень не удобно.

Несомненно, электронный документооборот становится необходимой потребностью бизнеса, как компьютеры и другие устройства, когда то вошли в нашу жизнь. Первыми кто проявил заинтересованность к услуге E-invoicing стали различные компании, имеющие огромное количество дебиторовкредиторов. Они регулярно отправляли документы одному и тому же большому количеству клиентов, так же их партнеры будут осваивать новый продукт в электронной среде и, несомненно, привыкнут так работать. Идея внедрения электронного документооборота оказалась полезна для большинства клиентов. Продукт E-invoicing среди банков является единственным. Сбербанк в системе E-invoicing использует те же самые алгоритмы безопасности, которые применяются для проведения платежей. Если клиент Сбербанка доверяет системе «Сбербанк Бизнес Онлайн» при обороте денежных средств, то те же алгоритмы безопасности используются специалистами при передаче электронных документов. В сравнении с обычной бумагой электронная система является более безопасной, ведь первая подвергается риску потери или уничтожения.

Архивное хранение документов это еще один важный аспект. Если к хранению подходить системно и квалифицированно как это заведено у крупных компаний, то они пользуются независимыми хранителями информации. Сбербанк же, внедряя систему E-invoicing, выступает в данной ситуации независимым архивом. Через свою систему «Сбербанк Бизнес Онлайн» клиент всегда может зайти в электронный архив и найти любой договор, счет-фактуру или акт приемки-передачи работ или услуг сгенерированные подписанные им и пересланные через систему E-invoicing. Эта система даже более безопасна с точки зрения хранения и более удобна ведь доступ к этим документам можно осуществить не только из офиса клиента, а из любого места где находится уполномоченное лицо. Конфиденциальность при пересылке документов ровно та же, что при пересылке денежных средств [3, с. 32].

По подсчетам до конца 2014 года около 8 тысяч предприятий были пользователями этой системой, все они сегодня обслуживаются в ЦентральноЧерноземном банке сбербанка России. За день в ЦЧБ к системе E-invoicing подключается в среднем порядка 8 компаний.

ОАО Сбербанк России 7 апреля 2015 года сообщил о старте сервиса выставления электронных счетов - фактур по услугам инкассации, валютному контролю и иным услугам банка, где предполагается взимание НДС [11].

При пересылке электронных счетов фактур так же используется система электронного документооборота E-invoicing, которая входит в состав «Сбербанк Бизнес Онлайн», доступная для всех клиентов банка - юридических лиц. Чтобы получать электронные счета - фактуры от Сбербанка России и других контрагентов организациям прошедшим регистрацию достаточно пройти онлайн подключение к E-invoicing. 
Бывает так, что фирма не зарегистрирована в «Сбербанк Бизнес Онлайн» и не планирует им пользоваться, но хочет подключить услугу электронного документооборота. В таком случае представителю компании необходимо посетить свое отделение Сбербанка. С ним подпишут дополнительное соглашение к договору с банком о согласии получать счета - фактуры в электронном виде. Специалист отделения проведет подключение к сервисам электронного документооборота 000 «Корус Консалтинг СНГ» как 100\% дочерней компании банка. С учетом фактического внедрения «цифровой» налоговой декларации по НДС с 2015 года и перекрестной сверки книг продаж и покупок всех контрагентов в налоговых органах пользования сервисом электронных счетов фактур становится особо важным для предприятий любых форм собственности. Использование сервиса исключает потери документов в пути или при хранении на местах, а так же возможные расхождения, связанные при ручном вводе данных с бумажных документов. Происходит сокращение издержек при пересылке счетов - фактур относительно бумажного вида «Почтой России» или другими службами почты.

«Корус Консалтинг СНГ» 14 мая 2015 года объявил о начале работы услуги сдачи отчетности E-invoicing, доступной на портале «Сбербанк Бизнес Онлайн» для клиентов Сбербанка. Это совпало с отчетной компанией в Федеральную налоговую службу за первый квартал 2015 года. Сбербанк России, как и все его клиенты, сдали электронные декларации по НДС с помощью услуги Еinvoicing. К концу декларационной компании за первый квартал 2015 года источники в налоговой службе сообщали о неразберихе, которая царила у многих крупных налогоплательщиках. Они жаловались, что не в силах составить отчетность по НДС по новым правилам. Причиной они называли неуверенность в своем программном обеспечении сдачи отчетности. Но руководители «Корус Консалтинг СНГ» были убеждены, что у Сбербанка и его клиентов таких проблем не будет. За крайне сжатые сроки специалистами был проведен полный цикл технологических обновлений программного обеспечения, были подготовлены и обновлены серверы для передачи больших объемов информации (до 12 Гб), которую должны были отправлять клиенты. А скорость шифрования документов была увеличена в 500 раз.

Благодаря E-invoicing Сбербанк и «Корус Консалтинг СНГ» лидируют на рынке сдачи отчетности. Более миллиона индивидуальных предпринимателей и юридических лиц постоянно используют систему дистанционного банковского обслуживания, «Сбербанк Бизнес Онлайн» куда включена услуга Еinvoicing.

Она соответствует всем нормам государственных и контролирующих органов. Ежемесячная плата за E-invoicing ниже среднерыночной стоимости подобных сервисов, а входящий в E-invoicing базовый пакет услуг отправки отчетности в государственные органы удовлетворяет потребностям почти $100 \%$ индивидуальных предпринимателей и юридических лиц [9, с. 398].

Рассмотрим динамику развития электронного документооборота взятых на основании данных Тамбовского ОСБ №8594 (рисунок 2). 


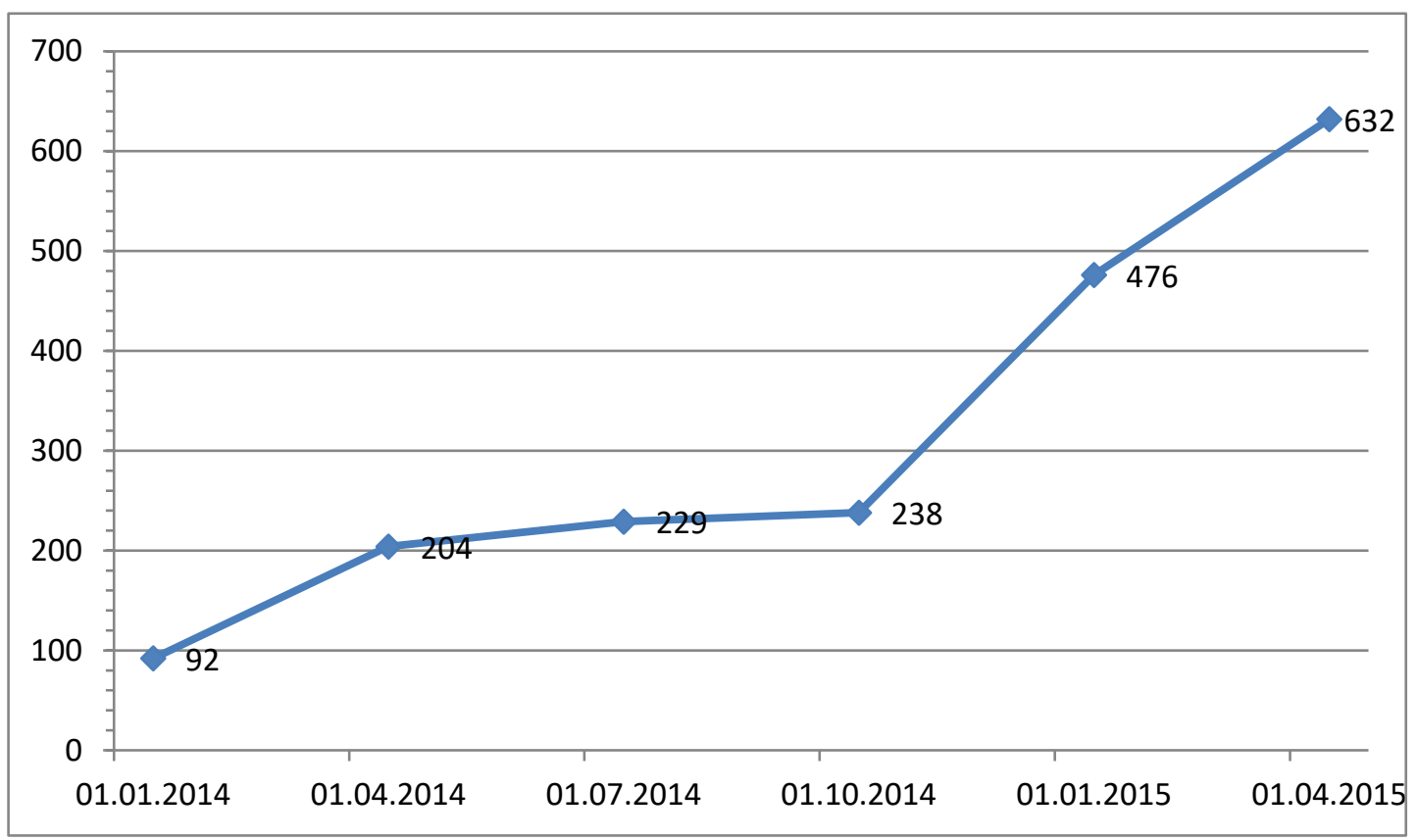

Рис. 2. Динамика развития электронного документооборота в Тамбовском ОСБ № 8594

Из динамики развития электронного документооборота видно, что система развивается достаточно быстрыми темпами и все больше организаций стремятся освоить виртуальное пространство.

По данным на 1.01.2014 года было зарегистрировано 92 юридических лица. По прошествии первого квартала этот показатель увеличился на 112 и составил 204 организации. К 1.07.2014 прибавилось еще 25 предприятий, и их общее количество стало равным 229. Самый большой прирост приходился с 1.10.2014 года по 1.01.2015 года. Этот скачек превысил прежний показатель на 238 и составил 476 организаций. На первый квартал текущего года показатель составил 632 предприятия Тамбовской области, которые зарегистрированы в системе E-invoicing. Это действительно полезная услуга, которая позволит быстро обмениваться различными документами и просто предоставит всю нужную информацию об операции по счетам и остаткам [11].

Bсе больше компаний с каждым днем присоединяется к системе электронного документооборота E-invoicing, что является самым лучшим подтверждением его эффективности для оптимизации бизнеса и сокращений издержек при ведении документации. В конечном счете, это обязательно скажется на повышении конкурентоспособности малых предпринимателей на рынке.

\section{Список литературы:}

1. Федеральный закон от 02.12.1990 N 395-1(ред. от 29.12.2012) "О банках и банковской деятельности" (с изм. и доп., вступающими в силу с 27.01.2013).

2. Федеральный закон РФ от 06.04.2011 г. № 63-ФЗ «Об электронной цифровой подписи». М.: Проспект, 2011.

3. Федеральный закон РФ от 27.07.2006 № 149-ФЗ «Об информации, информационных технологиях и о защите информации». М.: Ось-89, 2006. 32 с. 
4. Федеральный закон от 29.11.2014 N 382-ФЗ "О внесении изменений в части первую и вторую Налогового кодекса Российской Федерации" (29 ноября 2014 г.) Декларации по НДС будут представляться только в электронном виде.

5. Андреев А.П., Болвачев А.И. Дистанционное банковское обслуживание: практическое руководство // Кнорус. 2013.

6. Кроливецкая Л.П. Банковские электронные услуги. М.: Вузовский учебник, 2009. 400 c.

7. Лаврушин О.И. Банковское дело. Экспресс-курс. М.: КНОРУС, 2009. 352 с.

8. Мартиросян К. Онлайн-банкинг: возможности и перспективы развития // Банковские технологии. 2012. №1 100 c.

9. Рудакова О.С. Банковские электронные услуги: учебное пособие для вузов. М.: Вузовский учебник, 2012. $398 \mathrm{c.}$

10. Юдин В.В. Перспективы дистанционного банковского обслуживания физических лиц // Банковские услуги. 2010. №2.

11. Официальный сайт Сбербанка России. URL: www.sbrf.ru

12. Банк ДБО. URL: http://www.bankdbo.ru/

\section{References:}

1. Federal law from 02.12.1990 N 395-1(edited on 29.12.2012) "On banks and banking activities" (as amended. and additional, effective 27.01.2013).

2. Federal law of the Russian Federation dated 06.04.2011. №63-FZ "On electronic digital signature".

M.: Prospekt, 2011.

3. Federal law of 27.07.2006 № 149-FZ "On information, information technologies and protection of information". M.: Axis 89, 2006. 32 p.

4. Federal law dated 29.11.2014 N 382-FZ "On amending parts one and two of the Tax code of the Russian Federation" (29 November 2014) VAT returns will be submitted only in the electronic form.

5. Andreev A.P., Boltachev A.I. Remote banking services-tion: a practical guide // KnoRus. 2013.

6. Kroliveckaya L.P. Electronic Banking servicesю M.: High school textbook, 2009. 400 p.

7. Lavrushin O.I. Banking. Express course: a training manual. M.: KNORUS, 2009. 352 p.

8. K. Martirosyan Online banking: opportunities and prospects // Banking technology. 2012. № 1.

9. Rudakova O.S. Electronic banking services: textbook for universities. M.: High school textbook, 2012. 398 p.

10. Yudin V.V. Prospects of remote banking services to individuals // Banking services. 2010. № 2.

11. Official website of Sberbank of Russia. URL: www.sbrf.ru

12. Bank RBS. URL: http://www.bankdbo.ru/

(C) 2015, Сорина Е.И.

Электронная система

документооборота - E-invoicing
(C) 2015, Sorina E.I.

Electronic document management

system - E-invoicing 


\title{
Абдуллина Л.Б., Головнева Е.В. Опыт, проблемы и перспективы профессиональной подготовки современного учителя начальной школы
}

\author{
Golovneva E.V., Abdullina L.B. \\ Experience, problems and prospects vocational training \\ of the modern elementary school teacher
}

В статье рассмотрены актуальные проблемы, перспективы развития профессиональной подготовки современного учителя начальной школы. Значительное внимание уделено описанию опыта решения данной задачи на факультете педагогики и психологии университета.

Подчеркивается возрастающая роль начального и дошкольного образования в контексте реализации международной программы ЮНЕСКО «Образование для всех»; необходимость перестройки форм, методов, процесса обучения и воспитания детей и молодежи на основе личностно-ориентированного подхода; важность обеспечения преемственности между дошкольным, предшкольным, начальным и средним звеном основной школы с профессиональной подготовкой учителявоспитателя в русле задач непрерывного образования

Ключевые слова: профессиональная подготовка, учитель начальной школы, опыт, непрерывное образование

\section{Головнева Елена Вениаминовна}

Доктор педагогических наук, профессор, заведующая кафедрой

Башкирский государственный университет (филиал)

г. Стерлитамак, пр. Ленина, 49

\author{
Абдуллина Лилия Бакировна \\ Кандидат педагогических наук, доцент, декан \\ Башкирский государственный университет \\ (филиал) \\ г. Стерлитамак, пр. Ленина, 49
}

In article actual problems, prospects of development of vocational training of the modern elementary school teacher are considered. The considerable attention is paid to the description of experience of the solution of the given task at faculty of pedagogics and psychology of university. The increasing role of primary and preschool education in the context of implementation of the international program of UNESCO "Education for all" is emphasized; need of reorganization of forms, methods, process of training and education of children and youth on the basis of the personal focused approach; importance of ensuring continuity between a preschool, preschool, initial and average link of the main school with vocational training of the teacher-tutor in line with problems of continuous education

Key words: vocational training, teacher of an initial school, experience, continuous education

\author{
Golovneva Elena Veniaminovna \\ Candidate of Pedagogic Sciences, Professor, Head of \\ Department \\ Bashkir State University (brunch) \\ Sterlitamak, Prospect Lenina st., 49
}

\author{
Abdullina Lilia Bakirovna \\ Candidate of Pedagogical Sciences, Associate \\ Professor, Dean \\ Bashkir State University (brunch) \\ Sterlitamak, Prospect Lenina st., 49
}


Задача интеграции отечественного образования в мировое сообщество формирует новые представления о человеке и его образованности, выдвигает новые требования к системе непрерывного образования, в том числе, к профессиональной подготовке учителя начальных классов.

Согласно Международной стандартной классификации образования (1996) начальное образование выступает в качестве первого уровня получения основного образования. В Российской системе образования в отличие от терминов «элементарное» или «первичное», принятых за рубежом, применяется понятие «начальное образование». Данный термин «начальное образование» показывает его изначальную принципиальную значимость, определяющую всю последующую жизнь каждого человека. Именно начальное образование в системе непрерывного образования человека, отмечают С.А. Котова, О.А. Граничина, Л.Ю. Савинова, выступает базовой образовательной ступенью, от которой зависит общая образовательная основа населения, а также и всеобщие достижения образования в целом [3, с. 3]. Это - фундамент сохранения культурных ценностей и ведущий фактор формирования и развития личности растущего человека, способствующий вхождению подрастающего поколения в социальную систему современности. В связи с этим, одной из важнейших задач государства является обеспечение доступности, качества и эффективности начального общего образования, с одной стороны. С другой - создать необходимые условия для качественной подготовки современного учителя как исследователя, экспериментатора, воспитателя, организующего жизнь и деятельность обучающихся.

В настоящее время в мировой практике существуют разные международные программы, на основе которых проводится мониторинг знаний и умений школьников (например, PISA - Мониторинг знаний и умений в новом тысячелетии и PIRLS - Международный проект «Исследование качества чтения и понимания теста»). Сравнительная оценка результатов обучения российских школьников в программах PISA и PIRLS свидетельствуют, что по международным стандартам наши 10-летние школьники пока занимают лидирующие позиции, в то время как старшие показывают весьма низкие результаты. Это свидетельствует о высоком уровне подготовке российских учителей начальных классов и педагогов дошкольного образования.

В связи с происходящими положительными демографическими изменениями в стране и в Республике Башкортостан востребованы специалисты в системе начального общего и дошкольного образования.

Несмотря на востребованность педагогов начального и дошкольного образования, в Республике в последние годы наблюдается тенденция сокращения бюджетных мест на дневном и заочном отделениях в вузе. Актуальным остается и вопрос реализации регионального компонента при подготовке будущих педагогов в условиях введения ФГОС ВПО 2 поколения. Для этого требуется дополнительное финансирование для проведения спецкурсов и факультативов. В частности, в ДОУ значительная доля воспитателей не имеет базового специального образования. 
Перспективы развития факультета педагогики и психологии и подготовки студентов мы связываем с возрастающей ролью начального и дошкольного образования в контексте реализации международной программы ЮНЕСКО «Образование для всех».

Подготовка специалистов для системы начального общего образования на факультете педагогики и психологии ведется с 1976 г., для системы дошкольного образования с 1993 года. Подготовка осуществляется на двух выпускающих кафедрах - теории и методики начального образования и педагогики начального образования, профессорско-преподавательским составом, среди которых 5 докторов наук и 19 кандидатов наук (86\%).

О высоком уровне подготовки свидетельствуют успехи выпускников на региональных и всероссийских конкурсах «Учитель года», «Воспитатель года»: например, Юнусова С.А. - «Учитель года - 2008» (Республика Башкортостан); Кузьмина Е.С. - Победитель профессионального конкурса «Учитель года 2010» (Россия), Заслуженный учитель Республики Башкортостан, Лауреат Премии Президента Республики Башкортостан за высокое педагогическое мастерство; Демидова Н.А. - Победитель регионального этапа конкурса в номинации «Лучший воспитатель детского сада»; Овсянникова Н.В. - «Педагог года - 2012» (Республика Башкортостан).

С 2011/2012 г.г. в системе российского образования осуществляется переход на ФГОС 2 поколения в системе начального общего образования и на ФГТ в системе дошкольного образования. В связи с этим, на факультете педагогики и психологии становится приоритетной подготовка студентов к реализации требований федеральных государственных стандартов в их будущей профессиональной деятельности, на основании чего, в частности, были внесены дополнения в учебные планы профилей «Начальное образование» и «Дошкольное образование».

Подготовка педагогических кадров к реализации требований ФГОС и ФГТ на факультете осуществляется через организацию курсов повышения квалификации и переподготовки как для начальной школы, так и для дошкольных образовательных учреждений по актуальным проблемам модернизации современного образования.

На факультете реализуются следующие образовательные программы: «Организация воспитательно-образовательного процесса в современном дошкольном образовательном учреждении», «Внедрение требований федерального государственного образовательного стандарта в образовательный процесс», «Реализация федеральных государственных требований в образовательной области «Музыка» в дошкольном образовательном учреждении», «Информационно-коммуникационные технологии современном делопроизводстве» для студентов и др.

Осуществить эффективную подготовку высококвалифицированных кадров для системы начального и дошкольного образования в относительно сжатые сроки, реализовать основные цели и принципы стратегии модернизации российского образования: доступность - качество - эффективность, и, таким образом, выполнить социальный заказ общества, позволяют курсы професси- 
ональной переподготовки по направлениям: «Дошкольная педагогика и психология», «Начальное образование».

Дальнейшие перспективы развития системы профессиональной подготовки учителей-воспитателей в области начального и дошкольного образования мы связываем с: перестройкой форм, методов, самого процесса обучения и воспитания детей и молодежи на основе личностно-ориентированного подхода к совершенствованию образования:

- повышением профессионализма учителей начальных классов, педагогов дошкольных образовательных учреждений, достижением вершины творчества и мастерства [1];

- организацией непрерывного процесса обучения, переподготовки учителей начальных классов, воспитателей ДОУ, совершенствование функционирования магистратуры «Начальное Образование» на базе факультета педагогики психологии;

- внедрением современных технологий обучения, в т.ч. информационных, дистанционных технологий в процесс обучения будущих педагогов;

- реализацией развивающих технологий обучения в системе начального образования;

- расширением вариативности образовательной среды, спектра службы сопровождения ребенка;

- разработкой и организацией системы просветительской деятельности в социуме;

- духовно-нравственным воспитанием и развитием детей и молодежи в современных условиях;

- изменением приоритетов начального и дошкольного образования в направлении оптимизации процессов социализации ребенка для подготовки к эффективной жизнедеятельности в условиях Открытого общества [2].

Для педагога сегодня важно не только овладеть формами, средствами, приемами воспитания, изучить имеющийся опыт, но и найти индивидуальный способ их применения, сочетание в каждой конкретной педагогической ситуации, создать современные педагогические технологии, отобрать и возродить продуктивные традиции организации воспитательной работы прошлых лет, стать автором собственной концепции воспитания и реализировать себя как целостный субъект профессиональной деятельности.

Многообразные современные концепции воспитания и образования расширяют границы традиционной педагогики, многие аспекты понимания основных педагогических категорий, раскрывают безграничность педагогического творчества, определяют совокупность педагогических ценностей. Осознание своей позиции, системы смыслов, целей, ценностей наполняют педагогическую деятельность «личностным смыслом» (А.Н. Леонтьев) [4], избавляют ее от шаблонности, формализма.

В последние годы были отброшены многие положительные идеи, технологии, методические системы, накопленные в педагогической практике. В современных условиях возрождения прогрессивных традиций национальной духовной культуры, исторической духовности актуальной становится проблема 
восстановления искусственно прерванных связей с историей отечественного образования, его традициями, проблемами и достижениями, проблема выработки концептуальных идей в воспитания детей и молодежи в современном обществе, его мировоззренческих оснований.

Решение обозначенных проблем будет способствовать, на наш, взгляд, обеспечению преемственности между дошкольным, предшкольным, начальным и средним звеном основной школы с профессиональной подготовкой учителя-воспитателя в русле задач непрерывного образования как фактора постоянного самосовершенствования; решению трех ключевых задач: доступности, качества и эффективности образования; повышению ценности Учителя, Воспитателя в современном обществе.

\section{Список литературы:}

1. Абульханова-Славская К.А., Бодалев А.А., Деркач А.А., Кузьмина Н.В. Акмеология вчера, сегодня, завтра // Прикладная психология и психоанализ. 1997. № 1. С. 12-26.

2. Головнева Е.В. Оптимизация процесса формирования личности студента в системе профессиональной подготовки учителя. Стерлитамак: Стерлитамак. гос. пед. академия им. Зайнаб Биишевой, 2010.244 c.

3. Котова С.А., Граничина О.А., Савинова Л.Ю. Начальное образование в контексте программы ЮНЕСКО «Образование для всех: российское видение. СПб.: РГПУ им. А.И. Герцена. 101 с.

4. Леонтьев А.Н. Деятельность. Сознание. Личность. М.: Наука, 1977. 250 с.

\section{References:}

1. Abulkhanova-Slavskaya K.A., Bodalev A.A., Derkach A.A., Kuzmina N.V. Akmeologiya vchera, segodnya, zavtra // Prikladnaya psikhologiya i psikhoanaliz. 997. №1. Pp. 12-26.

2. Golovneva E.V. Optimizatsiya protsessa formirovaniya lichnosti studenta v sisteme professionalnoy podgotovki uchitelya. Sterlitamak: Sterlitamak. Gos. ped. akademiya im. Zaynab Biishevoy, 2010. 244 p. 3. Kotova S.A., Granichina O.A., Savinova L.Yu. Primary education in the context of the program of UNESCO Education for all: Russian vision. SPb.: Publishing house of RGPU of A.I. Herzen. $101 p$.

4. Leontyev A.N. Activity. Consciousness. Personality. M.: Science, 1977. 250 p.

(C) 2015, Абдуллина Л.Б., Головнева Е.В.

Опыт, проблемы и перспективы профессиональной подготовки современного учителя начальной школы
(C) 2015, Golovneva E.V., Abdullina L.B.

Experience, problems and prospects vocational training of the modern elementary school teacher 


\title{
Головнева Е.В. Народность как основной принцип национального воспитания в педагогическом творчестве К.Д. Ушинского
}

\author{
Golovneva E.V. \\ Nationality as the basic principle of national education \\ in pedagogical creativity of K.D. Ushinsky
}

В статье дана характеристика народности как основного принципа национального воспитания, научно обоснованного К.Д. Ушинским. Постижение родного языка педагог связывал с необходимостью изучения грамматики, играющей решающую роль в очеловечивании растущего человека. Проведен анализ его педагогического творчества: показано значение его наследия и методических книг для развития современного учителя, его культуры, творчества, гражданской позиции и ценностных ориентаций

Ключевые слова: национальное воспитание, народность, К.Д. Ушинский, родной язык

\section{Головнева Елена Вениаминовна}

Доктор педагогических наук, профессор, заведующая кафедрой

Башкирский государственный университет (филиал)

2. Стерлитамак, пр. Ленина, 49
The paper presents the characteristics of nationality as a basic principle of national education, sciencebased K.D. Ushinskii. Comprehension of the native language teacher linked to the need to study the grammar, which plays a crucial role in the humanization of the growing person. The analysis of his pedagogical creativity: it shows the importance of heritage and teaching books for the development of the modern teacher, culture, creativity, citizenship and values

Key words: national education, nationality, K.D. Ushinsky, native language

\section{Golovneva Elena Veniaminovna}

Candidate of Pedagogic Sciences, Professor, Head of Department

Bashkir state university (brunch)

Sterlitamak, Prospect Lenina, 49

В условиях демократического общества в качестве одного из ведущих принципов национального воспитания выступает народность, научно представленная К.Д. Ушинским. Возрождение национального самосознания связано с народной культурой воспитания, этнопедагогикой, выступающей фундаментом развития педагогического знания.

«Народ имеет свою характеристическую систему воспитания... Только народное воспитание является живым органом в историческом процессе народного развития», - писал К.Д. Ушинский. Ведущей идеей его педагогической системы является принцип народности воспитания детей.

Константин Дмитриевич впервые в русской педагогике обратил внимание на необходимость создания национальной системы воспитания. Педагог подчеркивал «Есть одна только общая для всех прирожденная наклонность, на которую всегда может рассчитывать воспитание, то, что мы называем народ- 
ностью. Всякая живая историческая народность есть самое прекрасное создание Божие на земле, и воспитанию остается только черпать из этого богатого и чистого источника» [3].

Идею народности педагог раскрывает во многих своих работах, в том числе в одной из первых статей «0 народности в общественном воспитании», впервые опубликованной в «Журнале для воспитания» $(1857$, №7,8) [3]. Отсутствие данного качества, по мнению К.Д. Ушинский, негативно сказывается на духовной культуры растущего человека. «Как ни разнообразны человеческие типы у образованных народов вследствие бесконечного разнообразия типов родовых, семейных и личных, природа всегда успевает в бесчисленном множестве характеристических черт в наружности человека выдвинуть на первый план черту народности... и в душе человека черта национальности коренится глубже всех».

Взаимосвязь национального и общечеловеческого К.Д. Ушинский понимал как опыт многих народов в деле воспитания, являющийся драгоценным наследием. «Научные истины, по его мнению, могут быть общими, психологические приемы и методические находки, добытые в разных странах, могут быть использованы любым народом, но система воспитания в целом у каждого народа своя, со своими национальными особенностями, учитывающая уровень развития общества, специфику национального характера и творческие силы самих различных слоев страны».

Ушинский убедительно показал, что родной язык это основа развития умственных способностей, морального облика ребенка. Он считал, что «родное слово есть именно та духовная одежда, в которую должно облечься всякое знание, чтобы сделаться истинной собственностью человеческого сознания $[1$, т. 5, с. 356]. «Усваивая родной язык, ребенок усваивает не только одни слова, их сложения и видоизменения, но бесконечное множество понятий, воззрений на предметы, множество мыслей, чувств, художественных образов, логику и философию языка» $[1$, т. 2, с. 560]. Постижение языка педагог связывал с необходимостью изучения грамматики, как науки, играющей решающую роль в очеловечивании растущего человека.

Исходя из понимания задач и методов психологии, К.Д. Ушинский создал учебные книги «Родное слово», «Детский мир и хрестоматию», которые многократно переиздавались, несмотря на официальные запреты в период реакции 80-х годов девятнадцатого века. Теоретические положения и методические принципы работы по ним были изложены педагогом в «Руководстве к преподаванию по «Родному слову», в котором тщательным образом раскрывается методика освоения детьми элементарного письма и звуковых упражнений, а также совместное освоение письма и чтения по азбуке. Соблюдая логику естественного следования материалу учебника, К.Д. Ушинский ведет с читателями своеобразную беседу-назидание, касаясь всех заслуживающих внимания моментов и особенностей работы с детьми на протяжении трех лет обучения. Вполне обоснованно наибольшее внимание в разговоре с адресатом выдающийся русский педагог уделяет специфике организации и методической инструментовке занятий с начинающими овладевать грамотой. Исходные ста- 
тьи-трактаты посвящены организационно-педагогическому обеспечению первоначального для детей курса: «о времени для начала ученья вообще и о необходимости соображаться с естественным развитием дитяти, зависящим от времени, при всяком новом шаге его обучении; об организации семейного и школьного класса; о школьной дисциплине; о значении обучения русскому языку в первоначальном курсе». Все эти позиции составитель рекомендаций заявляет со ссылками на здравый смысл, на опыт, на соответствующие научные данные.

Методические книги Ушинского являются ярким примером воодушевляющего управления образовательно-воспитательной деятельностью наставников детей. Они были высоко оценены передовыми учителями и прогрессивными педагогическими деятелями. Знакомство с советами и пожеланиями К.Д. Ушинского, высказанными в этих книгах, способствуют формированию и совершенствованию профессионального мастерства будущих наставников младших школьников, повышению уровня их профессиональной педагогической и методической культуры.

Анализируя педагогическое творчество Константина Дмитриевича Ушинского, мы видим, что это мыслитель, познавший всю сложность воспитательного процесса и понимающий, что в педагогике не может быть рецептов и догматических правил. С другой стороны - это педагог, подчеркивающий важность создания атмосферы свободы и творческого труда, создания благоприятствующих обстоятельств для формирования характера и развития ума ребенка.

Он разделял популярную в те годы точку зрения о совершенствовании каждого отдельного человека как средства совершенствования общества в целом. Чтобы выполнить свою ответственную миссию, воспитатель должен постоянно накапливать всестороннюю информацию о человеке, стремиться к познанию причины поведения и мотивы его деятельности в различных жизненных условиях и ситуациях. При этом воспитатель должен ориентироваться не на абстрактные схемы, а на реальный жизненный процесс; чутко прислушиваться к индивидуальным особенностям воспитанника. А для этого воспитателю важно развивать у себя наблюдательность, накапливать свой опыт, знать закономерности детского развития.

Педагогические идеи взгляды К.Д. Ушинского были высоко оценены многими прогрессивными педагогами того времени. Его педагогическое наследие является мощным источником творчества и для педагогической деятельности современных учителей. Советы великого педагога о том, как влиять на развитие ребенка, развивать умственные и физические способности детей, творческую самодеятельность ребенка, воспитывать привычки и чувства, имеют большую ценность и будут полезны каждому, кто неравнодушен к воспитанию подрастающего поколения.

Константина Дмитриевича Ушинского называют отцом русской педагогики, учителем учителей. Он был патриотом своей Родины, демократом по убеждениям, кристально честным человеком, методистом-воспитателем, идеи 
которого способствуют и в настоящее время развитию каждого учителя, его культуры, творчества, гражданской позиции и ценностных ориентаций.

\section{Список литературы:}

1. Ушинский К.Д. Собр. соч.: В 10 т. М.-Л.: АПН РСФСР, 1948-1952.

2. Ушинский К.Д. Избранные педагогические сочинения: В 2-х т. М., 1974.

3. Ушинский К.Д. О народности в общественном воспитании // Журнал для воспитания. №7, 8. 1857.

URL: http://dugward.ru/library/pedagog/ushinskiy_narodn_vospit.html

(C) 2015, Головнева Е.В.

Народность как основной принцип национального воспитания в педагогчческом творчестве К.Д.

Ушинского
(C) 2015, Golovneva E.V.

Nationality as the basic principle of national education in pedagogical creativity of K.D. Ushinsky 


\title{
Голубина О.А., Кочнев А.В. Особенности развития силовых качеств у девочек 13-14 лет занимающихся волейболом
}

\author{
Golubina O.A., Kochnev A.V. \\ Features of development of power qualities \\ among 13-14 years old girl volleyball players
}

В статье рассмотрены вопросы включения в тренировочный процесс упражнений, направленных на развитие силовых качеств у волейболисток 13-14 лет. В результате проведенных исследований, выявлены межгрупповые различия в показателях силовой подготовленности в зависимости от применения в учебно-тренировочных занятиях упражнений силового характера

Ключевые слова: силовые качества, кистевая динамометрия, волейбол, физические упражнения

\section{Кочнев Александр Владимирович}

Кандидат биологических наук, доцент Северный (Арктический) федеральный университет им. М.В. Ломоносова

2. Архангельск, Набережная Северной Двины, 17

Голубина Ольга Александровна

Кандидат педагогических наук, доцент

Северный (Арктический) федеральный

университет им. М.В. Ломоносова

2. Архангельск, Набережная Северной Двины, 17

\begin{abstract}
The article reviews problems of including power exercises in training course of girl volleyball players 13-14 years old. As the result of the research the differences in power efficiency are discovered, depending on usage of power exercises in training course
\end{abstract}

Key words: power qualities, carpal dynamometry, volleyball, physical exercises

\author{
Kochnev Aleksandr Vladimirovich \\ Candidate of Biological Sciences, Associate Professor \\ Northern (Arctic) Federal University named M.V. \\ Lomonosov \\ Arkhangelsk, Severnaya Dvina emb., 17

\section{Golubina Olga Aleksandrovna} \\ Candidate of Pedagogic Sciences, Associate Professor \\ Northern (Arctic) Federal University named M.V. \\ Lomonosov \\ Arkhangelsk, Severnaya Dvina emb., 17
}

Основной целью физического воспитания является укрепление здоровья, развитие физических способностей человека, формирование и совершенствование жизненно важных двигательных навыков и умений. Достойное место в системе физического воспитания занимает волейбол [1, с. 244].

Для того чтобы играть, достаточно владеть навыками подачи, приема и передачи мяча. Для того чтобы усвоить суть и правила игры, а также овладеть необходимыми приемами игры, много времени не нужно. Однако если говорить о достижении высоких спортивных результатов, то подготовка волейболистов представляет собой сложный процесс, направленный на всестороннее и совершенное овладение техникой и тактикой игры. При этом учитываются 
специфика волейбола, принципы тренировки, закономерности формирования двигательных навыков и развития физических качеств, возрастные особенности и другие факторы [3, с. 77].

Отличительная черта волейбола - сложность и быстрота решения двигательных задач в игровых ситуациях. Волейболист должен учитывать расположение игроков на площадке (своих и противника), предугадать действия партнеров и разгадать замысел противников, быстро произвести анализ сложившейся обстановки, вынести решение о наиболее целесообразном действии, выбрав его из своего арсенала, эффективно выполнить это действие.

Действия волейболистов происходят на сравнительно небольшой площадке. Отсюда специфика перемещений: небольшие расстояния, большая стартовая скорость, остановки после быстрых перемещений, прыжки и падения. Вот почему из всех физических качеств для волейболиста первостепенное значение имеют сила и быстрота. Высокий уровень современного волейбола как вида спорта делает его одним из эффективных средств всестороннего физического развития [4, с. 104$]$.

Цель работы - дать обоснование включения в тренировочный процесс упражнений, направленных на развитие силовых качеств у волейболисток 1314 лет. Для достижения цели были поставлены следующие задачи:

- Изучить в группах сравнения динамику развития силовых качеств.

- Дать обоснование применения физических упражнений, направленных на развитие силовых качеств у волейболисток 13-14 лет.

С целью обоснования включения в тренировочный процесс упражнений, направленных на развитие силовых качеств у волейболисток 13-14 лет было проведено исследование. В ходе исследования девочки прошли двукратное обследование: в сентябре 2013 и мае 2014 года. Обследование проводили в стандартизованных условиях в утренние часы (с 8 до 11 ч.).

Для эксперимента были сформированы две группы по методу случайной выборки. Группа A (15 человек) и группа Б (14 человек), которые занимались по программе общей, технической и специальной подготовке.

По условиям эксперимента основные части занятий были одинаковыми не только по времени, но и по объему используемых средств. Заключительные части занятий были равными по продолжительности (30 мин.), но по содержанию отличались между собой.

В первой группе в заключительной части выполнялись упражнения для развития силовых качеств по методике Кондратова Н.Н. [2, с. 32] с применением двух комплексов упражнений. Каждое упражнение завершалось выполнением растягивающих упражнений.

Во второй группе в заключительной части во все дни тренировочного процесса девочки выполняли дополнительно учебные игры по миниволейболу. В работе использовались следующие методы исследования для контроля за уровнем развития силовых качеств: силовая подготовленность поднимание туловища из исходного положения лежа (количество раз); силовая выносливость верхних конечностей - отжимания от гимнастической ска- 
мейки (количество раз); кистевая динамометрия (показатель силы определяли динамометром для ведущей руки).

В результате тестирования девочек по уровню развития силовых качеств установили отсутствие различий в группах сравнения до начала тренировок. Это позволило нам далее рассматривать группы, как репрезентативные для сравнения эффектов разных режимов тренировок.

При тестировании физических качеств, нами были выявлены удовлетворительные значения параметров, т.е. соответствовали средним нормативам. Существенных различий по средним показателям между группами исследуемых не было выявлено.

Сравнение показателей силовой выносливости рук у девочек волейболисток 13-14 лет представлено на рисунке 1. Из приведенных данных видно, что в группе А (15 человек) девочки, которые занимались по методике Н. Кондратова улучшили свои результаты на 46,7\%. В группе Б (14 человек) девочки улучшили свои показатели на 6,5\%.

Развитие этого качества начали с силовой выносливости и динамической силы, используя собственный вес, затем подключили эспандеры и тренажеры, постепенно увеличивая силовую нагрузку. После адаптации организма развивали устойчивость к статическим нагрузкам, начиная с подводящих упражнений и постепенно увеличивая время статических усилий. Оптимальный вес отягощения мы определяли, учитывая не максимальные возможности, а собственный вес девушек, исходя из того, что в 13-14 лет недопустимы максимальные силовые напряжения.

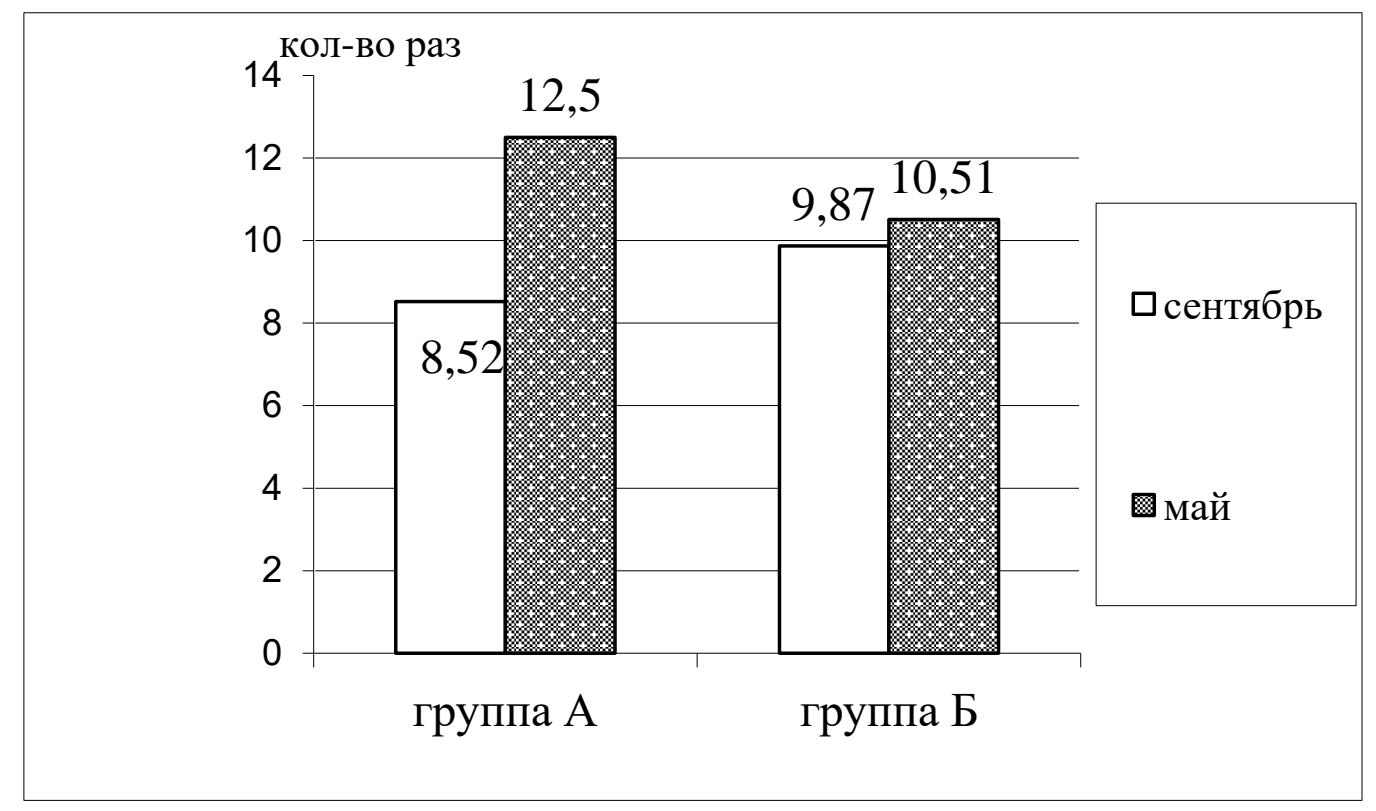

Рис. 1. Динамика изменения показателей силовой выносливости рук у девочек волейболисток 13-14 лет

Полученные результаты исследования в конце года свидетельствуют о недостаточном применении на учебно-тренировочных занятиях упражнений силового характера у девочек группы Б. 


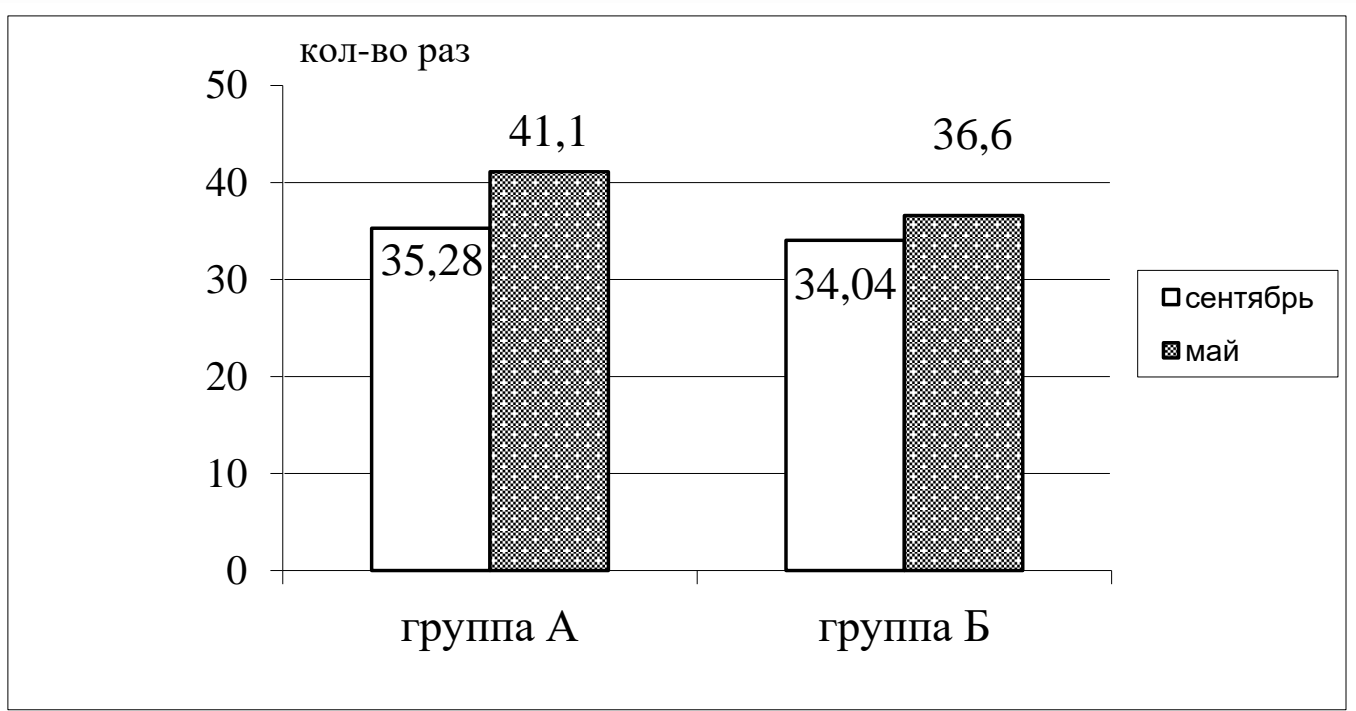

Pис. 2. Динамика изменений показателей силы мыши брюшного пресса (кол-во подъемов туловища) у девочек волейболисток 13-14 лет

Другим критерием оценки показателей изменений силовых качеств в нашем исследовании мы использовали тест на кол-во подъемов туловища за 1 мин. из положения лежа. При изучении динамики изменений показателей у волейболисток силы мышц брюшного пресса, установили, что в группе А данные улучшились на $16,7 \%$, а результаты в группе Б увеличились на 6,5\% (рис. 2).

Из приведенных данных видно, что в группе А (9 человек) девочки, которые занимались по методике Н. Кондратова улучшили свои результаты на 46,7\%. В группе Б (10 человек) девочки улучшили свои показатели на 7,5\%. Полученные результаты подтверждают необходимость включения в режим тренировок при занятиях волейболом специальных упражнений, направленных на развитие и поддержание такого важного физического качества, как сила.

О мышечной силе достаточно точно позволяет судить проба с применением ручного динамометра. Выявлено увеличение силовых показателей в кистевой динамометрии в группе А с 14,3 кг до 18,4 кг на 28,7\%, в группе Б с 13,7 кг до 14,12 кг соответственно на $3 \%$.

Наши исследования показали, что основные методы воспитания силы у девочек 13-14 лет следующие: метод повторного выполнения силового упражнения с отягощениями малого веса; метод повторного выполнения скоростносилового упражнения (метод динамических усилий); метод повторного выполнения статического силового усилия. Относительно больший объем мышечной работы, выполняемой в процессе использования метода повторного выполнения силового упражнения с отягощениями малого и среднего веса, приводит к интенсивному обмену веществ в организме спортсмена. Активизация трофических процессов положительно сказывается на развитие силы у девочек. Кроме того, при использовании этого метода устраняется опасность чрезмерного натуживания, вредного для организма юных спортсменок.

В результате проведенных исследований, выявлены межгрупповые различия в показателях силовой подготовленности в зависимости от применения в учебно-тренировочных занятиях упражнений силового характера. 
Нам удалось установить, что занятия в группе А, где применялись упражнения для развития силовых качеств по методике Н.Н. Кондратова имеют значительный положительный эффект.

Введение в программу учебно-тренировочных занятиях волейболом у юных волейболисток комплексов силовых упражнений, выполняемых в течение 10 мин., значительно повышает плотность занятий, улучшает силовую подготовленность и способствует росту уровня развития других физических качеств занимающихся.

При постепенном нарастании нагрузки и тщательной индивидуализации методики обучения эти упражнения не вызывают каких-либо отклонений в росте скелета и дают хороший педагогический эффект. Исследования показывают, что в возрасте 14 лет могут быть использованы силовые упражнения в общей системе физической подготовки при условии систематического врачебного контроля. Следует придерживаться дифференцированного подхода и стремиться увеличить силу отстающих в силовом отношении групп мышц. Некоторые тренеры нередко ограничивают комплекс средств силовой подготовки юных спортсменов применением в занятиях в основном только упражнений с гантелями, штангой, что принципиально неправильно. Эти упражнения сравнительно однообразны и монотонны, их многократное повторение быстро вызывает снижение работоспособности, особенно в занятиях с юными спортсменами. Применение силовых упражнений должно способствовать всестороннему физическому развитию занимающихся.

С целью более разностороннего воздействия на силовую подготовленность занимающихся и для повышения эмоциональности занятий следует использовать и такие упражнения, как парные и групповые упражнения с сопротивлением, игра «борьба за мяч», акробатические, гимнастические упражнения на снарядах и др. Положительные эмоции создают благоприятные условия для проявления и развития физических качеств, формирования и совершенствования двигательных навыков.

Поэтому для повышения эффективности тренировочных занятий полезно вслед за силовыми упражнениями включать средства тренировки более динамического характера, способствующие расслаблению мышечных групп, а также улучшению эмоционального состояния спортсменов.

\section{Список литературы:}

1. Ашибоков М.Д., Рюхина О.Ф. Формирование здорового образа жизни на занятиях волейболом // Вестник Адыгейского государственного университета. Серия 3: Педагогика и психология. 2007. №3. C.244-246.

2. Кондратов Н.Н. В силе - резервы скорости // Теория и практика физической культуры. 1995. №1. С. 32.

3. Станкевич Б.Я. Состояние, проблемы и перспективные направления научных исследований в волейболе // ППМБПФВС. 2013. №12. С.77-81.

4. Федоров Р.В. Разработка методики, направленной на иненсивное развитие скоростно-силовых качеств студентов-волейболистов // Ученые записки университета Лесгафта . 2008. №10. С.104-108.

(C) 2015, Голубина О.А., Кочнев А.В. Особенности развития силовых качеств у девочек 13-14 лет занимающихся волейболом
(C) 2015, Golubina O.A., Kochnev A.V. Features of development of power qualities among 13-14 years old girl volleyball players 


\title{
Дерябина Н.В., Лазарева Т.М. Компьютерное тестирование как одно из средств повышения эффективности обучения в техническом вузе
}

\author{
Deryabina N.V., Lasareva T.M. \\ Computer testing as one of the means of increasing the \\ efficiency of learning process at a technical institute
}

\begin{abstract}
В настоящее время компьютерное тестирование приобретает все большую значимость в повышении эффективности обучения в вузе. Оно обеспечивает всесторонний контроль учебного процесса. В статье рассматриваются основные виды контроля такие, как текущий, рубежный, итоговый
\end{abstract}

Ключевые слова: компьютерное тестирование, контроль, учебный процесс, обратная связь обучения, самоконтроль студентов

\section{Дерябина Наталья Владимировна}

Кандидат педагогических наук, доцент

Кемеровский технологический институт пищевой промышленности

2. Кемерово, бульвар Строителей, 47

\section{Лазарева Татьяна Михайловна}

Доцент

Кемеровский технологический институт пищевой промышленности

2. Кемерово, бульвар Строителей, 47
Nowadays computer testing acquires more significance in increasing the efficiency of the learning process in higher educational institutions. It provides the detailed control of the educational process. The article deals with the main types of control (current, intermediate, final) and the experience of teachers in using them

Key words: computer testing, control, learning process, feedback of teaching, self-control of students

\section{Deryabina Natalya Vladimirovna}

Candidate of Pedagogic Sciences, Associate Professor Kemerovo institute of food science and technology Kemerovo, blvd. Stroiteley, 47

\section{Lasareva Tatiana Mikhailovna \\ Associate Professor \\ Kemerovo institute of food science and technology Kemerovo, blvd. Stroiteley, 47}

Как показывает практика, из всех существующих средств обучения компьютеры наилучшим образом "вписываются" в структуру учебного процесса, наиболее полно удовлетворяют дидактическим требованиям и максимально приближают процесс обучения английскому языку к реальным условиям. Компьютеры могут воспринимать новую информацию, определённым образом обрабатывать её и принимать решения, могут запоминать необходимые данные, воспроизводить движущиеся изображения, контролировать работу всех мультимедийных средств обучения.

Компьютеры существенно расширяют возможности преподавателей по индивидуализации обучения и активизации познавательной деятельности студентов в обучении английскому языку, позволяют максимально адаптировать процесс обучения к их индивидуальным особенностям. Каждый студент 
получает возможность работать в своём ритме, т. е. выбирая для себя оптимальные объём и скорость усвоения материала [1].

Компьютер обеспечивает всесторонний (текущий, рубежный, итоговый) контроль учебного процесса. Контроль, как известно, является неотъемлемой частью обучения и выполняет функцию обратной связи между студентами и преподавателем.

При использовании компьютера для контроля качества знаний достигается большая объективность оценки. Кроме того, компьютерный контроль позволяет значительно сэкономить учебное время, так как осуществляется одновременная проверка знаний всех учащихся. Это даёт возможность преподавателю уделить больше внимания творческим аспектам работы со студентами [1].

Ещё одно достоинство компьютера - способность накапливать статистическую информацию в ходе учебного процесса. Анализируя статистические данные (количество ошибок, правильных/неправильных ответов, обращений за помощью, времени, затраченного на выполнение отдельных заданий и т. п.), преподаватель судит о степени и качестве сформированности языковых компетенций студентов [3].

Благоприятные возможности создают компьютеры и для организации самостоятельной работы студентов на занятиях английского языка. Учащиеся могут использовать компьютер для изучения отдельных тем и для самоконтроля полученных знаний. Причём компьютер является самым терпеливым педагогом, способным сколько угодно повторять любые задания, добиваясь правильного ответа и, в конечном счёте, автоматизации отрабатываемого навыка [3].

Успех в обучении иностранному языку во многом зависит от того, в какой степени качество знаний учащихся находится в поле зрения преподавателя и какое внимание уделяется профилактике ошибок.

Одним из наиболее эффективных средств контроля в обучении иностранному языку по праву считается тест. Сегодня для качественной разработки тестов многие преподаватели успешно применяют компьютерные технологии. Основная задача такого вида диагностики - не только проверить уровень знаний учащихся, но и выявить типичные трудности в усвоении материала. Тесты являются экономной формой контроля и более объективным показателем степени усвоения студентами языкового материала. Систематическое тестирование стимулирует активность и внимание студентов на занятиях, повышает их ответственность при выполнении аудиторных заданий [2].

Задания текущего и рубежного контроля успеваемости измеряют уровень сформированности умений и навыков по иностранному языку за определенный отрезок времени. Задания должны быть согласованны с учебным материалом конкретного тематического модуля соответствующего уровня сложности. Кроме констатирующей и оценивающей функций текущий и рубежный контроль выполняют диагностическую функцию [4]. 
Преподавателями кафедры иностранных языков КемТИПП разработаны тесты рубежного, текущего и итогового контроля по разным направлениям для студентов дневной и заочной форм обучения.

Тестовые задания по английскому языку для рубежного контроля знаний студентов первого и второго года обучения в бакалавриате очной формы предназначены для проверки знаний студентов после освоения семестровых материалов по английскому языку. Тесты каждого семестра имеют задания, предназначенные для проверки рубежных знаний по разным аспектам языка: лексике, грамматике, чтению и аудированию. Материал дается студенту в электронном виде. Время выполнения теста 60 минут. Студенты имеют возможность узнать свои результаты по окончанию теста. Рубежный контроль проводится один раз в семестр: в первом семестре по модулям «Я и моя семья», «Мое образование», «Родной край»; во втором семестре - «Моя Родина», «Страна изучаемого языка», «Питание и здоровье». Каждый модуль охватывает материал трех - четырех тем. Поэтому на рубежном контроле осуществляется проверка знаний по нескольким близким темам одновременно.

Для осуществления текущего контроля были разработаны компьютерные игры-викторины по страноведению в двух вариантах, которые являлись своего рода коллоквиумами. Для проведения учебной игры-викторины (первый вариант) на заданную тему преподаватель готовил вопросы, с которыми он знакомил студентов за две недели до начала игры.

Второй вариант предусматривал самостоятельную работу студентов в малых группах. Они готовили вопросы по пройденному материалу, вопросы на сообразительность по заданной для каждой группы теме. После того как данная тема была изучена на аудиторных занятиях, студенты сдавали составленные вопросы преподавателю. На основе вопросов составлялся компьютерный тест текущего контроля. Такие формы проведения текущего контроля позволяют судить об успешности овладения пройденной конкретной темы.

Таким образом, текущий и рубежный контроль обеспечивает своевременную обратную связь обучения, способствует улучшению учебного процесca.

Одной из задач текущего контроля является подготовка студентов к итоговому контролю и знакомство с форматом международных экзаменов по иностранному языку. Итоговый контроль - это проверка конечных результатов обучения, выявление степени овладения студентами системой языковых компетенций. При подготовке к нему происходит более полное обобщение и систематизация усвоенного материала.

Итоговый контроль проводится в виде зачета по практической части и экзамена по всему пройденному материалу. Зачет проходит устно в конце семестра по подготовленным преподавателями вопросам. Экзамен является ведущей, наиболее значимой формой итогового контроля, позволяющего судить об эффективности усвоения изученного материала по иностранному языку.

На кафедре практикуется смешанная форма проведения экзамена: сначала студент выполняет письменную часть в виде теста. Разработанные тесты охватывают следующую тематику: биографии известных ученых, научные до- 
стижения и разработки пищевой технологии, проблемы экологии, современная экономика и другие. Но тестовая форма контроля имеет недостатки, которыми нельзя пренебрегать при проведении экзамена. При работе над тестом повышается вероятность влияния на результат случайных факторов. Поэтому во вторую часть экзамена включается устное сообщение по изученным разговорным темам.

Компьютерное тестирование открывает большие возможности для формирования навыков самоконтроля. При подготовке к экзамену все студенты имеют возможность проверить свои знания и умения во внеаудиторное время в компьютерных классах. При затруднениях в процессе самоконтроля студенты могут обращаться к преподавателю в часы консультаций.

Таким образом, активное использование компьютерного тестирования в учебном процессе в сочетании с современными информационными технологиями помогает поддерживать нужный образовательный уровень студентов за счет повышения интереса при работе на компьютере и возможности работать в режиме тренинга, тем самым, предоставляя преподавателю возможность уделять больше внимания индивидуальной работе со студентами.

\section{Список литературы:}

1. Кречетников К.Г. Индивидуализация обучения при использовании информационных технологий // Информационные технологии в науке и образовании. Шахты. 2002. С. 100-102.

2. Майоров А.Н. Теория и практика создания тестов для системы образования. М.: Интеллект-центр, 2002. $296 \mathrm{c}$.

3. Матрос Д.Ш., Полев Д.М., Мельникова Н.Н. Управление качеством образования на основе информационных технологий и образовательного мониторинга. М.: Педагогическое общество России, 2001. $128 \mathrm{c}$.

4. Мельникова М.Б Теория и практика конструирования педагогических тестов. М.: Логос, 2002. 495 с.

(C) 2015, Дерябина Н.В., Лазарева Т.М. Компьютерное тестирование как одно из средств повышения эффективности обучения в техническом вузе
(C) 2015, Deryabina N.V., Lasareva T.M.

Computer testing as one of the means of increasing the efficiency of learning process at a technical institute 


\title{
Елманова И.В. Вопросы формирования коммуникативных компетенций у студентов СПО
}

\author{
Elmanova I.V. \\ The problems of communicative competence \\ formation in students of vocational education
}

В статье рассматриваются подходы к решению проблемы формирования профессиональных коммуникативных компетенций у студентов СПО медицинских образовательных учреждений в соответствие с современными требованиями. Позиция автора состоит в том, что в образовательном процессе должны создаваться благоприятные условия для формирования и развития коммуникативных навыков у подростков и с этой целью предлагается использование различных современных педагогических технологий методов и приёмов. Дискуссия и ролевая игра рассматривается как форма формирования коммуникативной компетенции Ключевые слова: профессиональное образование, компетентность, коммуникативность

\section{Елманова Ирэна Владимировна}

Аспирант, преподаватель

Медищинское училище № 21

г. Москва, ул. Остроумовская Бол., 12
The article in concerned with tho problems of professional communicative competence formation in student of vocational education institutions in accordance with modern reguirements. According to the author is opinion, tho educational process is to create favourable conditions for the formalion and development of communicative skills in adolescents and for this purpose wide varicty of modern pedagogical technologies, methods and technigues are.Discussion and role-playing games as a form of communicative competence formalion areintroduced

Key words: vocation education ,competence, communication skills

\author{
Elmanova Irena Vladimirovna \\ Postgraduate, Teacher \\ Medical School № 21 \\ Moscow, Ostrovskaya Bol. st., 12
}

Среднее профессиональное образование имеет трехсотлетнюю историю. Оно всегда было направлено на обеспечение насущных кадровых потребностей страны: от петровской эпохи до постсоветского времени.

На фоне постоянных изменяющихся экономических, социальных и технологических перемен знания и профессиональные умения быстро устаревают. В условиях происходящего и ожидаемого стремительного развития науки, техники и социально-экономической сферы, что является характерной особенностью современности, и особенно в условиях глобализации экономики и революционных изменений в информационных и коммуникационных технологиях, техническое и профессиональное образование должно стать жизненно важным аспектом развития отечественного образовательного процесса. Профессиональное образование сегодня должно способствовать социальному, культурному и экономическому развитию личностного потенциала людей, в 
целях более активного участия в достижении поставленных профессиональных целей, а также в достижении определенной карьеры.

В условиях необходимости поиска новых взаимоотношений между образованием, сферой труда и обществом в целом профессиональное образование должно существовать как составная часть отечественной системы образования и обучения. Современное профессиональное образование должно сегодня поставлено на такой научный и методологический уровень, чтобы способствовать повышению качества жизни. Чтобы достичь такой цели в образовании, на нынешнем этапе развития профессионального образования важно объединить усилия всех заинтересованных сторон: образовательной системы и сферы труда, органов управления, студентов и их родителей.

Сегодня, в период реформирования образования, вызывает озабоченность неопределенность в планировании политики профессионального образования, думается, оно должно отвечать не только государственным, а, по возможности, и региональным экономическим и социальным аспектам общественного развития, учитывать прогноз возможных изменений спроса на различные группы товаров и услуг, профессиональные умения и навыки в целях более полного соответствия системы профессионального образования стремительным изменениям, происходящим в науке, технике и социальноэкономической жизни современного российского общества. Одной из стратегических задач современной профессиональной школы является формирование профессиональных компетенций будущих специалистов. В образовательном процессе во главу угла ставятся не знания, а личность студента, то есть его личные качества, в том числе компетентность, поэтому в последнее время одним из основных подходов к образованию стал компетентностный подход.

Ситуация, которая сложилась с молодыми специалистами, вызывает тревогу: на работу приходят люди, не обладающие способностями к творческому труду. Среднее профессиональное образование вступила в ту пору, когда оно должно перейти на новые принципы работы, чтобы исправить это положение. Главный из них - учеба не только ради получения знаний, но и ради подготовки к конкретному делу. Следует сказать о том, что проблема подготовки разностороннего специалиста, обладающего высоким уровнем культуры (в том числе и культуры слова) и мобильно действующего в условиях динамичного общества в наше время занимает умы многих исследователей и еще не решена окончательно. Одним из главных условий решения этой проблемы, на мой взгляд, является целенаправленное формирование у будущего специалиста коммуникативной компетентности, главной составляющей которой является вербальное общение (коммуникация). Коммуникативная компетентность один из важных компонентов профессиональной компетентности выпускников медицинских средне специальных учреждений, которым, так или иначе, независимо от специализации, предстоит работать с людьми, а, следовательно, общаться с ними и использовать речь как средство воздействия. Прежде чем перечислить коммуникативные умения, на формирование которых должно быть направлено обучение студентов медицинского училища (колледжа), не- 
обходимым определить виды речевой деятельности, которыми должны владеть наши выпускники:

ния);

1) организующая речевая деятельность (управление процессом обще-

2) речевое управление интеллектуальной деятельностью;

3) стимулирующая речевая деятельность (мотивация, привлечение внимания пациентов, постановка задачи);

4) контролирующая деятельность (так называемая, обратная связь).

При сформированной языковой компетенции можно говорить о формировании коммуникативных умений, особенно в учебно-профессиональной сфере общения, так как именно общение в данной сфере становится серьезной проблемой для студента с момента обучения в образовательном учреждении. Многолетний опыт позволяет сделать вывод о том, что у будущих студентов не сформирована языковая база, которая позволила бы им активно и плодотворно участвовать в учебном процессе по избранной специальности. Большинство абитуриентов не владеют умениями, столь необходимыми для обучения в среднем специальном учебном заведении: они не умеют строить как письменное, так и устное монологическое высказывание, затрудняются сформулировать понятия, не владеют достаточной аргументацией суждений, имеют крайне бедный словарный запас, отсутствуют навыки научного спора. Студенты первого курса не все умеют высказывать свои мысли, вести дискуссию, логически осмыслять информацию, не знакомы с проблемным методом изложения материала, то есть не умеют вступать в коммуникацию в необходимых им сферах общения. Студенты, пришедшие со школьной скамьи, привыкли к описательному изложению информации в учебниках, на занятиях и к воспроизведению данной информации, то есть к детальному пересказу - таковы результаты применения в большинстве случаев объяснительно-иллюстративного метода обучения на всех ступенях системы среднего образования. Для формирования коммуникативных навыком необходимо студентам с первого курса начинать изучать два типа общения: вербальный и невербальный (бессловесный). Вербальный (словесный) тип - это наиболее распространенное средство общения между людьми с помощью речи. Беседа с пациентом целая наука и настоящее искусство. Овладеть им в совершенстве невозможно без высокой культуры профессиональной речи. Преподавателями общеобразовательных и специальных дисциплин образовательного учреждения делается акцент на том, что диалог с пациентом следует вести так, чтобы все сказанное воспринималось легко и однозначно, чтобы разъяснения и ответы на вопросы были правильно сформулированы и убедительны. Преподаватели следят за тем, чтобы студенты избегали языковые стандарты, всевозможный словесный мусор, профессиональный жаргон, развязность. Средний медицинский работник должен уметь предоставлять информацию пациентам и их родственникам о состоянии здоровья после согласовании с врачом и в пределах своей компетенции. Должен подобрать правильные слова, чтобы снять у пациента страх перед заболеванием и лечением. Студент должен помнить, что пациент страдает не только от боли, но и от страха, тревоги, уныния, тоски, бессилия. При 
беседе с пациентом учитываются и его возрастные особенности. Страх - это эквивалент боли, поэтому задача медсестры избавить пациента от страха, используя знания коммуникативных компетенций. Для развития и закрепления коммуникативной компетенции студентам в процессе обучения необходимо предлагать активные групповые методы обучения, с использованием приёмов игровой технологии и эвристической беседы. Дискуссия как форма формирования коммуникативной компетенции. Благодаря механизму дискуссии студент отходит от черт эгоцентрического мышления и учится оценивать точку зрения другого. Исследования показали, что групповая дискуссия повышает мотивацию участников в решение обсуждаемых проблем. Дискуссия даёт эмоциональный толчок к поисковой активности участников, что в свою очередь реализуется в их конкретных действиях. В качестве объекта дискуссионного обсуждения выступают не только специально сформулированные проблемы (ситуационные задачи), но и случаи из профессиональной практики и межличностные отношения самих участников. Студентам предлагается прокомментировать различные ситуации из медицинской практики (случаи из жизни близких, знакомых), объяснить пациенту необходимость сестринского вмешательства, сообщить ему полную информацию о процедуре. При этом беседовать с пациентом следует тихим голосом, наблюдая за его реакцией, не отвлекаясь на посторонние раздражители, глядя ему в глаза. Как показывает практика, метод группового обсуждения способствует уяснению каждым участником своей собственной точки зрения, развитию инициативы, умение взять ответственность за свои действия, а также развивает коммуникативные качества и умения. Важным моментом процесса формирования коммуникативных навыков является мысленное проигрывание своего поведения в различных ситуациях. Планирование своих действий “в уме” является составной частью нормального протекающего коммуникативного действия. Способность человека действовать “в уме" может быть целенаправленно использована для обеспечения “контролируемой спонтанности”, являющейся важной характеристикой компетентного коммуникативного поведения. Игровой блок. Говоря об игровых методах обучения, мы делим их на операционные и ролевые. Операционные игры имеют определённую структуру, которую определяет алгоритм “правильности" и “неправильности" принимаемого решения, то есть обучаемый видит результат, которое оказывает его решения на будущие события. Операционные игры применяются, как средство обучения специалистов, формирование их личностных, деловых качеств и профессиональной компетентности. Примером могут служить разработанные методические приемы: аукцион, мозговой шторм, реставрация, цепочка. Наибольший интерес для совершенствования личности представляют ролевые игры (примером могут служить разработанные методические ролевые игры: телемост, круглый стол, научная конференция, интеллектуальная разминка, аукционов, научная лаборатория). В условиях ролевой игры студенты сталкивают с ситуациями, которые характерны для его реальной деятельности и ставят перед необходимостью изменить свои установки. Тогда создаются условия для формирования новых, более 
эффективных, коммуникативных навыков. Именно этот вид игр может быть взят в основу, социально-психологического тренинга.

Общение - это не игра в одни ворота. Общение - это взаимодействие двух людей - двух динамических систем, превращающихся в одну. Необходимым атрибутом общения любой живой системы является обратная связь. Понятно, что отсутствие обратной связи есть еще один, достаточно часто встречающийся коммуникативный барьер, а медицинские работники как никто должны владеть искусством коммуникации в силу своих профессиональных особенностей. Формирование коммуникативной компетенции является актуальной проблемой и задачей для всего педагогического коллектива средне специального медицинского образовательного учреждения, решение которой имеет важное значение, как для каждого конкретного человека, так и для общества в целом.

\section{Список литературы:}

1. Бодалева А.А. Психологическое общение. М.: Институт практической психологии. Воронеж: Н.П.О, Модек, 2006. 256 с.

2. Винокур Т.Г. Информативная речь как обнаружение разных коммуникативных намерений говорящего и слушающего. М., 2003.

3. Емельянов Ю.Н. Теория формирования и практика совершенствования коммуникативной компетентности. М., 2000. 403 c.

4. Жуков Ю.М., Петровская Л.А, Растянников Л.В. Диагностика и развитие компетентности в общении. М., 2000. 104 c.

(C) 2015, Елманова И.В.

Вопросы формирования коммуникативных компетенций у студентов СПО
(C) 2015, Elmanova I.V.

The problems of communicative competence formation in students of vocational education 


\title{
Eм Ю.M. \\ Опыт реализации программы профильного образования в ходе подготовки квалифицированных кадров для проекта ЗАО «ВНХК»
}

\author{
Em Yu.M. \\ Experience of implementation of the profile \\ education program during preparation of qualified \\ personnel for the project of JSC VNHK
}

Сложность реализуемых проектов на Дальнем Востоке России, требует объединения усилий производственного сектора, высшей школы и общеобразовательных учреждений в подготовке квалифицированных кадров. В ходе решения указанных задач возникает необходимость пересмотра некоторых параметров программ профильного образования. Изложены выводы практических работ

Ключевые слова: нефтепереработка, ВНХК, Роснефть класс, образование, опыт

\section{Ем Юрий Михайлович}

Магистрант

Дальневосточный Федеральный Университет Приморский край, г. Владивосток, о. Русский, $n$. Аякс, 10

\begin{abstract}
Complexity of the realized projects in the Far East of Russia, demands association of efforts of production sector, the higher school and educational institutions in preparation of qualified personnel. During the solution of the specified tasks there is a need of revision of some parameters of profile education programs. Conclusions of practical works are stated
\end{abstract}

Key words: oil processing, VNHK, Rosneft class, education, experience

\author{
Em Iurii Mikhaylovich \\ Master \\ Far Eastern Federal University \\ Primorsky Krai, Vladivostok, Russky Island, Ajax, 10
}

Сердцем будущего нефтехимического кластера на юге Дальнего Востока станет нефтеперерабатывающий и нефтехимический комплекс дочернего общества ОАО «НК «Роснефть» - ЗАО «Восточная нефтехимическая компания» (ВНХК) мощностью до 30 млн. тонн по перерабатываемому углеводородному сырью.

Проектируемый нефтеперерабатывающий объект, в виду сложности основных технологических процессов, требует объединения усилий производственного сектора, высшей школы и общеобразовательных учреждений в подготовке квалифицированных кадров. 
Одной из основ Кадровой политики проекта является корпоративная Программа непрерывного образования Школа-ВУЗ-Предприятие. ОАО «НК «Роснефть» реализует программу на Дальнем Востоке в комплексном взаимодействии с Дальневосточным Федеральным университетом (ДВФУ) как Стратегическим партнером. В свою очередь, Программа устойчивого развития Компании включает в себя реализацию Молодежной политики, первым тезисом которой является: «...формирование кадрового резерва Компании из числа лучших выпускников школ, мотивированных к получению качественного профессионального образования и трудоустройству в Компанию...», т.е. выпускников «Роснефть классов» опорных общеобразовательных учреждений региона [5].

В ходе решения указанных задач, в соответствии с Программой повышения конкурентоспособности, сотрудниками Инженерной школы ДВФУ ведется работа с учащимися «Роснефть классов», которая включает в себя: проведение циклов профессионально ориентирующих лекций; проведение дискуссий в формате «круглый стол»; научное руководство подготовкой конкурсных работ на региональные и межрегиональные научно-практические конференции; участие в проведении «Дней Роснефти» и других практикоориентированных мероприятиях (экскурсии, дни открытых дверей и др.).

Анализ проводимых работ показывает, что неполное представление о природе профессий нефтегазовой промышленности, отсутствие практических отраслевых задач снижает эффективность всего процесса. Простейшее статистическое исследование показывает, что часть выпускников отклоняются от поступления на базовую кафедру и выбирают более традиционные для региона направления высшего образования.

Совместными усилиями заинтересованных сторон программы ШколаВУЗ-Предприятие, была осуществлена попытка разобраться в причинах отклонения от ожидаемых результатов. Анализ всех элементов программы приводит к выводу о необходимости проведения более ранних профессионально ориентационных работ.

Программа «Роснефть класс» является одним из путей обеспечения прикладного контента и направлена на расширение профессионально ориентирующих компетенций. Практическая реализация программы сталкивается с опережающим смещением «фокус группы» на более ранний возраст, ввиду нелинейности акселерации, которая в свою очередь вызвана облегченным осмыслением дискретных концепций, когнитивным дуализмом [2, с.2] информации. В расширяющемся пространстве, между сформировавшейся юностью и поступлением в профильные классы, неиспользуемый потенциал переводит сознание в состояние пассивного ожидания, что может привести к социальному инфантилизму [3, с.3].

Таким образом, мы приходим к рассмотрению необходимости «сдвига влево» всего графика работ по программе «Роснефть класс». Анализ педагогической литературы показывает, что аналогичные ситуации возникали и ранее, на границах качественного улучшения информационного пространства. Прохождение подобных этапов отечественная педагогика решала с помощью уси- 
ления комплекса базисных знаний прикладными задачами в более ранних классах.

Для заполнения образующейся ниши предлагается расширить начальную профессионально ориентирующую работу на возраст перед поступлением в «Роснефть класс»; интегрировать информационную работу опорных школ в один из межрегиональных порталов [4].

Со своей стороны, для рационального использования системы психологических стимулов заложенных в программу Школа-ВУЗ-Предприятие, коллегами из высшей школы предлагается определенная расстановка инициатив [1, с. 121-122], которая обеспечивает выдвижение Предприятием научнопрактических задач творческим коллективам, что создает реальный эффект от работы академического исследовательского аппарата и приближает перспективу практического применения.

Проведенное исследование показало, что реализация комплекса работ по подготовке квалифицированного персонала для проектируемого нефтеперерабатывающего и нефтехимического комплекса ЗАО «ВНХК» сталкивается с необходимостью: актуализации сроков проведения профессионально ориентирующих работ; интеграции информационной работы опорных школ в один из межрегиональных порталов; приближения к производственной проблематике задач для творческих коллективов.

В целом же, имеющаяся практика совместной деятельности участников программы демонстрирует раскрытие неисчерпаемого источника энергии учащегося, что в конечном итоге и является одной из основных целей программы и поставленной задачей.

\section{Список литературы:}

1. Соломенник С.Ф., Нисковская Е.В., Автомонов Е.Г., Надточин К.А., Формирование тематики научных исследований молодыми специалистами на предприятиях транспорта нефти и газа // Наука и образование в жизни современного общества. Ч. 3. Тамбов: Консалтинговая компания Юком, 2015. $164 \mathrm{c}$.

2. Рапуто А.Г. Когнитивный дуализм визуализации дидактических объектов // Московский Финансовопромышленный университет. 2011.

URL: http://www.econ.rae.ru/2011/08/516.pdf

3. Шевченко А.Н. Педагогические технологии преодоления социально-профессионального инфантилизма учащихся колледжа: автореферат диссертации. Москва. 2002. 162 с.

4. Объединенный портал Роснефть классов «Роснефть. Энергия развития».

URL: http://www.rosneft-klass.narod.ru

5. Официальный сайт ОАО «НК «Роснефть». Молодежная политика компании.

URL: http://www.rosneft.ru/Development/personnel/young_specialists/

\section{References:}

1. Solomennik S.F., Niskovskaya E.V., Avtomonov E.G., Nadtochin K.A., Formation of scientific scopes researches by young specialists of the transport oil and gas enterprises // Science and education in life of modern society. P. 3. Tambov: UCOM consulting company, 2015. 164 p.

2. Raputo A.G. Cognitive dualism of didactic objects visualization. Moscow Financial and industrial university.

2011.

URL: http://www.econ.rae.ru/2011/08/516.pdf

3.Shevchenko A.N. Pedagogical technologies of overcoming of social and professional infantility of college pupils: abstract of the thesis(es). Moscow. 2002.162 p. 
4. Integrated portal of Rosneft classes "Rosneft. Energy of development".

URL: http://www.rosneft-klass.narod.ru

5. JSC Rosneft official site. Youth policy of the company.

URL: http://www.rosneft.ru/Development/personnel/young_specialists/

(C) 2015, Ем Ю.M.

Опыт реализации программы профильного образования в ходе подготовки квалифицированных кадров для проекта ЗАО «BHXK»
(C) 2015, Em Yu.M.

Experience of implementation of the profile education program during preparation of qualified personnel for the project of JSC VNHK 
DOI: $10.17117 /$ na.2015.05.085

Поступило в редакцию: 14.05.2015

\title{
Есимбекова А.О. Проблемы полиязычия
}

\author{
Yessimbekova A.O. \\ Problems of multilinguism
}

В статье рассматриваются проблемы полиязычия с точки зрения становления и развития полиязычного индивида. А также некоторые аспекты функции языка в полиязычных коллективах

Ключевые слова: полиязычие, полиязычный индивид, активное и пассивное владение языком

\section{Есимбекова Асылжан Омаровна Магистр, старший преподаватель \\ Жетысуский государственный университет им. И. Жансугурова \\ Казахстан, г. Талдыкорган, ул. Жансугурова 187 A}

Problems of multilinguism from the view of becoming and developing multilingual individual are considered in the article. Some aspects of language function of multilingual groups are done as well

Key words: multilinguism, multilingual individual, passive and active knowledge of language

\section{Yessimbekova Assylzhan Omarovna Master, Senior Teacher \\ Zhetysu State university named I. Zhansugurov Kazakhstan, Taldykorgan, Zhansugurov st., $187 \mathrm{~A}$}

Интерес к проблеме полиязычия проявляется как с точки зрения становления, развития полиязычного индивида, так и с позиции описания характеристики многоязычного общества. Особенно важность исследования в Казахстане проявляется повышенным интересом к изучению иностранных языков, изменением отношения к изучению культур других народов, возрастающими задачами социального и экономического развития страны, набирающим темпом научно-технического прогресса. С точки зрения педагогической науки огромное значение имеет то, что прогресс в науке и технике предъявляет новые требования к современному специалисту и к системе профессиональных знаний.

Рассмотрим основные проблемы полиязычия в лингвистике и психолингвистике. Наиболее распространённой проблемой является интерференция - вторжение одной языковой системы в другую. В лингвистическом энциклопедическом словаре В.А. Виноградов дает следующее определение: «Интерференция - взаимодействие языковых систем в условиях двуязычия, складывающегося либо при языковом контакте, либо при индивидуальном усвоении неродного языка» [1, с. 197]. У. Вайнрах считает интерференцию отклонением от норм любого из языков, происходящие в результате наложения двух систем в процессе речи. Изучение двуязычия, с точки зрения социологии, имеет важное при исследовании двустороннего отношения между говорящими и между двумя говорящими коллективами. При этом каждый «кодирует» на сво- 
ем языке и свободно декодирует то, что говорит его партнер. 0 подобных отношениях можно говорить, когда речь идет о диалектах или близкородственных языках. Данная психолингвистическая установка говорящих становится ощущением регулярности между системами и осознание этих различий, как ясных формул перехода, даже теми людьми, которые не занимаются сравнительным языкознанием. Изучение подобных двух систем привлекает большое внимание лингвистов, и, конечно же, психологов, которые изучают психологическую природу систем у носителей языка.

Одним из немаловажных аспектов является функция языка в полиязычных коллективах. Некоторые функции оказывают консервативное влияние на языковые нормы, чем другие. Существенная роль консервативных факторов в языке как инструменте образования. Образовательные учреждения, где например, обучают литературе, обучающим прививают бдительное отношение к интерференции. А в повседневной жизни пренебрегается даже тщательность произношения. В таких случаях интерференция становится привычкой. Если язык теряет престиж, например, теряет статус государственного языка, уменьшается и сопротивление интерференции [2, с. 22].

Проблема интерференции представлено многими научными работами современных лингвистов. Кроме лексической, грамматической и фонетической интерференции изучаются и другие трудности освоения языков $[3$, с. 331]. Безусловно, интерференция является категорией методики преподавания иностранных языков и определяются приемы обучения, которые бы реализовали принцип опоры на язык.

Следующая наиболее значимая проблема - контакт языковых систем, которая затрагивает такие вопросы лингвистики как:

- языковой сдвиг (замещение одного языка другим);

- переключение (попеременное употребление языков в зависимости от обстоятельств);

- слияние (объединение языков в единую систему).

Еще одна проблема касательно дву/полиязычных носителей - это речевое поведение. Какими критериями определить понятия родной язык, основной язык, первостепенный язык? Какой язык является главным источником интерференции? На каком языке думает полиязычный индивид? Еще ряд вопросов относительно речевого поведения не могут быть разрешены посредством только лингвистики.

С точки зрения У. Вайнраха родной язык тоже может оказаться объектом интерференции со стороны языков, усвоенные позже. Основным языком является тот язык, которым носитель очень хорошо владеет на данном этапе жизни. Также в сознании полиязычного индивида доминирующим языком будет тот язык, который хорошо закреплен практикой. Если полиязычный носитель владеет только грамотой, то этот язык тоже может быть основным, несмотря на уровни устного владения другими языками.

Отсутствие интерференции в некоторых случаях, с точки зрения психологии, не значит, что двуязычный индивид выполняет переключение между двумя раздельными системами. Существуют специальные тесты и процедуры 
по которым возможно определить в какой степени две грамматические, фонологические или семантические системы являются раздельными у того или иного носителя двух языков. Любое лингвистическое исследование предполагает различие конечной продукции носителя - то есть некоторый конечный текст и стоящую систему за этим текстом. Это существует в мозгу у говорящего и позволяет продуцировать ему этот текст и огромное количество соответствующих языковой норме высказываний, которых понимают другие говорящие. Подобное различие изучают и исследователи языковых контактов. Интересным является тот факт, что говорящий может с точностью воспроизвести приличное количество моделей иностранного языка, не владея этим языком как целой системой, имеется ввиду, без наличия умений воспроизводить большое количество комбинаций данного языка.

Владение иностранными языками наделяет человека другими качествами. Процесс изучения языка способствует развитию психических механизмов. В результате человек, владеющий одним и более иностранными языками, кодирует один и тот же смысл средствами разных языков, а также понимать выраженные на разных языках сообщения.

Связи с другими известными словами, а также путь который проходит новое слово, становясь средством доступа к единой информационной базе индивида часто не осознается самим обучающим. Однако, выявление таких связей значимо для понимания функционирования слов в индивидуальном вокабуляре многоязычного индивида, а также для улучшения эффективности работы с лексикой на занятиях иностранного языка. Формальные связи между словами известных языков являются важной характеристикой индивидуального вокабуляра в условиях учебного многоязычия. 3.Б. Девицкая [4, с. 14], выполняя психолингвистическое исследование усвоения лексики при учебном многоязычии, отмечает об ином строении лексического запаса слов многоязычного индивида. Изначально, в процессе овладения вторым иностранным языком формальные связи ослабевают в пользу смысловых. В последующем, формальные связи можно интерпретировать как попытку мотивировать еще недостаточно наполненную смыслом форму слова для облегчения оперирования им. Смысловые связи становятся ведущими в процессе словами второго иностранного языка. Они могут быть основаны на разных принципах, семантически организующих лексикон, и задействуют слова всех известных языков, но ведущей остается роль родного языка и связанная с ним система внеязыковых знаний, ощущений и эмоций.

Существует большая разница между пассивным и активным владением языка. По мнению У. Вайнраха, способность декодировать сообщения первична и даже отчасти независима от способности кодировать их. В психологии интересным представляется описание процесса, когда индивид начинает разбираться в незнакомом языке без всякой помощи.

Итак, мы пришли к выводу, что речевое поведение полиязычных носителей крайне разнообразно. Полиязычные носители могут владеть двумя и более иностранными языками свободно, как и родным языком, то это говорит о незначительной интерференции в подобных ситуациях. Но если они владеют 
первым иностранным языком хорошо, а последующими слабее, то будет наблюдаться сильная интерференция. Одни люди могут легко переключаться с одного языка на другой, а для других это сложный процесс. Одни полиязычные носители могут выбрать одну форму поведения, другие вести себя по-разному в зависимости от ситуации. Конечно же, условия освоения языка влияют на языковое поведение полиязычных носителей.

\section{Список литературы:}

1. Виноградов В.А. Диссглоссия. Интерференция. Конвергенция. Лингвистический энциклопедический словарь. М.: Сов. Энциклопедия, 1990. 685 с.

2. Вайнрах У. Языковые контакты. Киев: Вища школа, 1979. 263 с.

3. Muhamedova R. The use of Russian conjunctions in the speech of bilingual Kazakhs. International journal of bilingualism. Vol. 13. Issue 3. 2009. 331-356 p.

4. Девицкая 3.Б. психолингвистическое исследование усвоение лексики при учебном многоязычии. Автореф. на соис.к.фил.н. Тверь. 2008. 14 с.

(C) 2015, Есимбекова А.О.

Проблемы полиязычия
(C) 2015, Yessimbekova A.O.

Problems of multilinguism 


\title{
Завьялова С.В., Завьялова А.А. Применение ИКТ в музейно-экскурсионной деятельности
}

\author{
Zavyalova S.V., Zavyalova A.A. \\ The use of ICT in the Museum and tour activities
}

Статья посвящена опросам использования информационно-компьютерных технологий в музейно-экскурсионной деятельности.

Раскрываются цели, задачи, преимущества использования презентаций в музеях малых городов. На основе типологии презентаций показана их роль в развитии личности

Ключевые слова: музейно-экскурсионная деятельность, информационно-компьютерные технологии, презентация

\section{Завьялова Светлана Владимировна}

Кандидат исторических наук, преподаватель Железнодорожный техникум (филиал) МГУПС г. Нижний Новгород, Канавинский р-н, ул. Чкалова, 5 A

\section{Завьялова Александра Арефьевна \\ Учитель высшей категории Шахунская СОШ № 1 им. Д. Комарова Нижегородская обл., г. Шахунья, ул. Советская, 15}

\begin{abstract}
The article surveys the use of information and computer technology in the Museum and tour activities. Describes goals, objectives, advantages of using presentations in museums in small towns. On the basis of typology presentations of their role in personality development
\end{abstract}

Key words: museum and tour activities, information and computer technology, presentation

\author{
Zavyalova Svetlana Vladimirovna \\ Candidate of Historical Sciences, Teacher \\ Railway College (branch) MSURT \\ Nizhny Novgorod, Kanavinsky district, Chkalova st., 5 \\ A \\ Zavyalova Alexandra Arefjevna \\ Teacher of highest category \\ Shahunskaya school № 1 named D. Komarov \\ Nizhny Novgorod region, Shakhunya, Sovetskaya st., \\ 15
}

В музеях наряду с собирательской и исследовательской деятельностью проводится просветительная работа в виде экскурсионного и лекционного обслуживания населения. Разрабатываются лектории для детей дошкольного возраста, младших классов, среднего и старшего звена, для студентов, так как постоянными посетителями музея являются обучающиеся. Учитывая возрастные особенности учащихся, современные требования к качеству знаний и формированию умений, краеведческий материал преподносится в контексте с региональной историей, историей России для закрепления, применения исторических, географических, обществоведческих знаний, развития критического мышления, логического сопоставления, сравнения, формулировки выводов; воспитания любви к родному краю. В работе с посетителями в музее широко применяются информационно-компьютерные технологии (ИКТ). С помощью компьютера моделируются определенные предметные ситуации для расшире- 
ния кругозора восприятия имеющихся в музее экспозиций. В музеях малых городов практически отсутствует современная аппаратура, потому широко используется программа по составлению презентаций, с помощью которой можно совершить виртуальную экскурсию, оказаться в период какой-либо эпохи или по интерактивной карте пройти маршрут по достопримечательностям города.

Сущность понятия «презентация» (по ресурсам Интернета) заключается:

- в обычном смысле - показ нового товара, рекламная акция, предъявление широкой публике новой коллекции мод или кинофильма;

- в узком смысле как документ, созданный в программе PowerPoint.

Презентация представляет собой последовательность сменяющих друг друга слайдов - то есть электронных страничек, занимающих весь экран монитора. Если демонстрация документа идет на большом экране, то собравшиеся в аудитории видят чередование своеобразных плакатов, на каждом из которых могут присутствовать текст, фотографии, рисунки, диаграммы, графики, видеофрагменты, и все это может сопровождаться звуковым оформлением - музыкой или речевым комментарием диктора. Объекты на слайдах могут сразу присутствовать на слайдах, а могут возникать на них в нужный момент по желанию докладчика, что усиливает наглядность доклада и привлекает внимание аудитории именно к тому объекту или тексту, о которых в данный момент идет речь. В случае необходимости докладчик может перейти к любому из слайдов презентации, не пролистывая вперед или назад все слайды, отделяющие нужный слайд от текущего.

В образовании возникает такая проблема как лучше рассказать, как лучше показать материал [1], поэтому и в музейной деятельности применима такая же проблематика при предоставлении информации.

При решении такой проблемы презентации можно разделить на типы:

- проблемные, в самом названии презентации закладывается проблема, в завершении показа учащиеся могут сделать вывод;

- тематические презентации, посвященные определенной теме, при этом составитель определяет цель, что необходимо раскрыть в презентации, какие задачи требуется решить, чтобы просмотр программы нес не только информационную нагрузку, но и образовательную, развивающую, познавательную, интригующую [2, с. 76]. Тематические презентации могут заканчиваться крылатыми выражениями, поговорками, пословицами, вопросами, о чем была презентация, списками литературы, рекомендуемыми для чтения. При составлении презентации возможно применение музыкального сопровождения, чтение стихов. Такие презентации сотрудники музеев могут составлять совместно с учащимися и учителями-предметниками, учитывая их запросы и пожелания, требования сегодняшнего времени. Игровые презентации. В процессе игры легче, проще усваивается материал, и он проигрывается не навязываемым способом предоставления информации [2]. Информационные презентации. В ходе такого типа презентаций предоставляем определенные сведения о каком-либо объекте, архитектурном сооружении, городе, площади города и т.д. Экскурсионные презентации. Экскурсия - это коллективный осмотр музея или внутри 
музейного объекта, проводимый по намеченной теме и специальному маршруту под руководством специалиста-экскурсовода в образовательных и воспитательных целях [3, с. 274]. В музеях малых городов с помощью презентации распространен такой вариант проведения экскурсий как виртуальные. К примеру: «Площадь родного города», «Памятники родного города», «Улицы родного города», предоставляющие информацию в динамике через взгляд на прошлое и настоящее. Справочные презентации. С помощью этого типа презентаций представляются сведения об истории города, районах региона.

Каково значение презентации, в чем ее достоинства, почему она занимает немаловажное место в работе музея?

Информация, отраженная в презентации сопровождается наглядностью.

Ресурсы компьютерной программы предоставляют возможность осуществлять показ информации в виде диаграмм, таблиц, схем, применять звуковое сопровождение.

После просмотра презентации значительно легче воспринимается экскурсия, учащиеся узнают предметы, получается диалог между посетителем и экскурсоводом.

Показ презентации и просмотр выставки взаимно дополняют друг друга.

Применение компьютерной технологии позволяет реализовать задачи как образовательные, так и развивающие, воспитывающие.

Благодаря презентациям, использованию ИКТ в музейной работе с посетителями осуществляется взаимодействие музея и школы в деле духовно нравственного, умственного развития личности.

\section{Список литературы:}

1. Е.Г. Калинкина. Применение ИКТ в предметном обучении. Основные подходы к конструированию уроков с использованием компьютерных технологий.

2. Завьялова С.В. Использование ИКТ при заочной форме обучения по предметам гуманитарного цикла // Современные тенденции в образовании и науке. Ч. 11. Тамбов, 2014.

3. К.Г. Левыкин, В. Хербст. Музееведение. Музеи исторического профиля. М.: Высш. шк., 1988. С. 274

(C) 2015, Завьялова С.В., Завьялова А.А. Применение ИКТ в музейно-экскурсионной деятельности
(C) 2015, Zavyalova S.V., Zavyalova A.A.

The use of ICT in the Museum and tour activities 


\title{
Любимова А.С. \\ Влияние фармакологических средств на восстановление работоспособности студентов, занимающихся силовым фитнесом и пауэрлифтингом
}

\author{
Liubimova A.S. \\ The influence of pharmacological agents on the recovery of the \\ students involved in strength training fitness and powerlifting
}

Рассматривается влияние основных фармакологических средств на восстановление после физических нагрузок в силовых видах спорта и их корректное применение

Ключевые слова: восстановление, фармакологическое средство, силовая нагрузка

Любимова Анастасия Сергеевна

Старший преподаватель

Пермская государственная фармацевтическая академия

г. Пермь, ул. Крупской, 46
Examines the impact of pharmacological agents on recovery after exercise in endurance sports and their correct application

Key words: recovery, pharmacological tool, power load

Liubimova Anastasia Sergeevna

Senior Lecturer

Perm state pharmaceutical academy

Perm, Krupskoy st., 46

Современная тренировка в силовых видах спорта (пауэрлифинг, силовой фитнес) обусловлена длительным выполнением работы с большими весами и требует силовой выносливости, предъявляет высокие требования к оптимальной работе всех систем организма и к его кардиореспираторной и мышечной системам, а также к психическому состоянию. Проблема восстановления после больших физических нагрузок всегда остается актуальной, особенно для студенчества, которое является наиболее уязвимой частью молодежи.

В силовых видах спорта выделяются три основных этапа тренировочного процесса: подготовительный, соревновательный и переходный. Основной этап - подготовительный, этап всесторонней подготовки спорсмена, он продолжается, как правило, 14-16 недель и повторяется дважды (иногда трижды) в годичном тренировочном цикле занимающегося в двух (трех) ответственных соревнованиях [1, с.56].

Силовые физические нагрузки, используемые в учебно-тренировочном процессе, нередко требуют применения фармакологических препаратов (разрешенных Минздравом РФ) для поддержания высокой работоспособности спортсменов и ускорения восстановительных процессов организма. 
Одним из важнейших направлений в комплексной системе восстановления является целенаправленная регуляция обмена веществ лекарственными средствами и продуктами специализированного питания.

Анализ специальной литературы позволил нам предложить ряд фармакологических препаратов (разрешенных к применению), наиболее часто используемых в спортивной медицине $[2,5,6]$. Данные препараты направлены на системы восстановления и повышения работоспособности организма студента.

Спортивная фармакология является частью так называемой «фармакологии здорового человека». Она получила бурное развитие в последнюю четверть двадцатого века и, особенно, - в начальном периоде двадцать первого, как главная альтернатива допингу. В отличие от допинга, искусственно стимулирующего работоспособность организма за счет запредельного расходования энергетических ресурсов, фармакологические средства восстановления направлены, в первую очередь, на восполнение затраченных при нагрузке резервов [4, с 75].

К основным задачам спортивной фармакологии относятся:

- Лечение заболеваний и перенапряжений;

- Ускорение течения процессов восстановления;

- Профилактика заболеваний и перенапряжений;

- Повышение иммунологической устойчивости организма;

- Повышение спортивной выносливости и работоспособности.

Под действиями фармакологических средств быстрее восполняются энергетические ресурсы организма, активизируются ферменты, ускоряется процесс метаболизма, достигается равновесие нервных процессов, ускоряется выделение продуктов катаболизма. Применение этих средств для повышения работоспособности студентов основывается на учете функционального состояния основных систем организма и этапов подготовки в годичном тренировочном цикле. Подбор индивидуального комплекса фармакологических средств для каждого в целом обусловлен:

- данными текущих динамических и биомеханических наблюдений (дневник тренировок);

- наличием выявленного «слабого» звена (ЦНС, сердечно-сосудистая система и др.);

- особенностями адаптации, гиперактивности или «нечувствительности» к одним и тем же препаратам;

- необходимостью профилактики и лечения хронических заболеваний;

- психологическими особенностями поведения студента-спортсмена в соревновательном периоде;

Основные требования к фармакологическим препаратам: низкая токсичность и безвредность, отсутствие нежелательных побочных эффектов, удобная форма выпуска.

Основные принципы использования фармакологических средств восстановления: 
1. Проверка индивидуальной переносимости препарата с учетом возрастных, силовых, функциональных особенностей организма;

2. Использование препаратов в соответствии с рекомендацией спортивного врача-консультанта;

3. Строго дозированное применение препаратов, поскольку непрерывное употребление фармакологических средств может привести к увеличению риска токсических последствий, аллергических реакций, адаптации организма к лекарственному средству, иногда к обратной реакции;

4. Внимательное комплектование препаратов (возможность антагонизма);

5. Крайне осторожное использование фармакологических средств в период роста организма;

6. Исходя из тренировочной нагрузки, составление необходимого комплекса препаратов (объем, направленность, интенсивность и т.п.).

Мы предлагаем наиболее распространенные и широко применяемые, прошедшие апробацию и зарекомендовавшие себя поливитамины. Курс применения препаратов составляет 20 дней как средство профилактики, 30 дней лечения: Аскорутин, Глутамевит, Декамевит, Комплекс витаминов В, Поливитаплекс, Супрадин, Ундевит, Фолиевая кислота.

Среди фармакологических средств восстановления и повышения спортивной работоспособности и профилактики переутомления особое место занимают витамины: Аскорбиновая кислота (витамин C), Никотиновая, Пиридоксин, Рибофлавин, Тиамин, Токоферола ацетат (витамин Е).

Широко применяются в периоды интенсивных тренировок противогипоксические средства, оказывающие положительное действие на организм при развитии кислородной недостаточности: Бемитил, Глутаминовая кислота (аминокислоты), Гутимин.

Препараты энергетического действия способствуют быстрейшему восполнению затраченной при больших физических нагрузках биологической энергии, восстановлению нормального метаболизма клеток, активации деятельности ферментных систем, повышения устойчивости организма к гипоксии. Препараты метаболического действия корректируют обмен веществ, создают условия для выполнения анаэробной и аэробной работы, являются надежной защитой при перенапряжениях миокарда, мышц, других органов. Препараты пластического действия - повышают содержание белка и нуклеиновых кислот, приводят к увеличению мышечной массы и силы, играют важную роль в предупреждении физического перенапряжения: Аденозинтрифосфорная кислота (АТФ), Аминалон, Глутаминовая кислота, Калия оротат, Кальция глицерофосфат, Милдронат, Метилурацил, Пикамилон, Пирацетам (аминокислоты), Пиридол, Рибоксин, Фитин, Фосфаден, Янтарная кислота

При больших физических нагрузках и нервно-психическом перенапряжении у занимающихся могут возникнуть невротические состояния тревожного ожидания, ипохондрические реакции, реакции пресыщения, которые требуют вмешательства врача. Медицина рекомендует средства, которые нормализуют психическую деятельность спортсмена: Амизил, Тауремизил, Эхинопсин нитрат. 
Результаты научных исследований и передовой практический опыт показали, что для повышения качества и эффективности учебно-тренировочного процесса следует обязательно планировать и практически использовать комплексы восстановительных средств. Сегодня не вызывает сомнения факт, что восстановление - неотъемлемая часть системы подготовки, не менее важная, чем рациональный режим нагрузок. Единство тренировки, соревнований и восстановления - основа правильно подготовленной подготовки атлета [3, с. 27].

При планировании восстановительных мероприятий важно учитывать, что их общая интенсивность и направленность во многом зависят от периода тренировочного процесса и задач конкретного микроцикла. После отдельных занятий необходимо учитывать характер протекания процессов утомления и восстановления в организме спортсменов.

Значение проблемы восстановления важно не только для тренеров, преподавателей работающих со спортсменами, а также для учебных групп в школе, вузе, занимающихся физической культурой, поскольку обеспечение полноценного восстановления - одно из основных условий повышения работоспособности и оздоровительного эффекта тренировочных занятий.

\section{Список литературы:}

1. Альциванович К.К. $1000+1$ совет о питании при занятии спортом. Минск.: Современный литератор, 1999. $288 \mathrm{c}$.

2. Граевская Н.Д., Долматова Т.И. Спортивная медицина. Курс лекций и практические занятия.

М.: Советский спорт, 2004. 360 c.

3. Дубровский В.И. Реабилитация в спорте. М.: Физическая культура и спорт, 1991. 206 c.

4. Коробов А.В. Проблема восстановления в условиях высоких тренировочных и соревновательных нагрузок. М.: Медицина, 1974. 150 с.

5. Макарова Г.А., Алексаняни Г.Д., Локтев С.А. и др. Методологические принципы оценки функционального состояния организма спортсменов. Краснодар, 1991. 20 с.

6. Рудаков А.Г. Особенности изучения и применения лекарственных средств в спортивной медицине: Автореф. докт. дис. М., 1990. 38 с.

\section{References:}

1. Altianovich K.K. $1000+1$ the Council on nutrition when you exercise. Minsk.: A modern writer, 1999. 288 p.

2. Gruevska N.E., Dolmatova T.I. Sports medicine. A course of lectures and practical classes. Moscow: Soviet sport, 2004. 360 p.

3. Dubrovsky V.I. Rehabilitation in sport. Moscow: Physical culture and sport, 1991. $206 p$.

4. Korobov V.A. Problem of rehabilitation in conditions of high training and competitive loads. M.: Medicine, 1974. $150 \mathrm{p}$.

5. Makarova G.A., Alexanian G.D., Loktev S.A. Methodological principles of evaluation of the functional state of organism of sportsmen. Krasnodar, 1991. 20 p.

6. Rudakov A.G. the study and use of drugs in sports medicine: author. doctor. dis. M., 1990. 38 p.

(C) 2015, Любимова А.С.

Влияние фармакологических средств на восстановление работоспособности студентов, занимающихся силовым фитнесом и пауэрлифтингом
(C) 2015, Liubimova A.S.

The influence of pharmacological agents on the recovery of the students involved in strength training fitness and powerlifting 


\title{
Мамаева Н.А., Тривер Т.А., Черникова Н.А. Некоторые аспекты использования кейс-метода в учебном процессе
}

\author{
Mamaeva N.A., Chernikova N.A., Triver T.A. \\ Some aspects of using of case-method in the learning process
}

Исходя из содержательных и методических особенностей обучения дисциплине «Математика» в статье представлена классификация кейсзаданий, а также возможность с помощью кейсметода формировать у курсантов и слушателей военных вузов аналитические, практические, творческие, коммуникативные и другие навыки Ключевые слова: интерактивные методы обучения, кейс-метод, кейс-задание, классификации типов кейсов

\section{Черникова Наталья Анатольевна}

Кандидат педагогических наук, доцент

Омский автобронетанковый инженерный институт

2. Омск, 14 военный городок, ОАБИИ

\section{Тривер Татьяна Андреевна \\ Доцент \\ Омский автобронетанковый инженерный институт \\ 2. Омск, 14 военный городок, ОАБИИ}

\section{Мамаева Наталья Анатольевна \\ Кандидат технических наук, доцент \\ Омский автобронетанковый инженерный институт \\ 2. Омск, 14 военный городок, ОАБИИ}

\begin{abstract}
The article presents the classification of case assignments based on substantive and methodological features of teaching discipline "Mathematics", and the possibility of using the case method to form the cadets and students of military schools analytical, practical, creative, communication and other skills
\end{abstract}

Key words: interactive teaching methods, case method, case assignment, classification of cases types

\section{Chernikova Natalya Anatolyevna}

Candidate of Pedagogic Sciences, Associate Professor Omsk Tank Automotive Engineering Institute

Omsk. 14 voennygorodok, OTAEI

\author{
Triver Tatiana Andreevna \\ Associate Professor \\ Omsk Tank Automotive Engineering Institute \\ Omsk. 14 voennygorodok, OTAEI
}

\author{
Mamaeva Natalya Anatolyevna \\ Candidate of Engineering Sciences, Associate \\ Professor \\ Omsk Tank Automotive Engineering Institute \\ Omsk. 14 voennygorodok, OTAEI
}

В настоящее время в российских вузах, в том числе и военных, происходит переход на новые федеральные государственные стандарты подготовки специалистов, которые определяют высокие требования к уровню знаний и умений выпускников. Приоритетной задачей, стоящей перед преподавателями математики, является повышение уровня фундаментальной математической подготовки курсантов с усилением ее прикладной направленности. Достижение этой задачи не возможно без использования в учебном процессе активных и интерактивных методов обучения. Среди интерактивных методов обучения 
все более популярным и востребованным становится метод кейс-стади (casestudy - метод анализа конкретных ситуаций), или кейс-метод.

Впервые кейс-метод был применен в 1924 году в школе бизнеса Гарвардского университета. В России применять этот метод в обучении стали в 80-х гг., сначала в МГУ, а затем в академических и отраслевых институтах. Данный метод чаще всего применяется при обучении предметам гуманитарного, социального и экономического циклов, однако, как показала практика, он может быть использован и при обучении математике в военно-инженерном вузе [1].

Анализ научно-методической литературы позволяет сделать вывод о недостаточном количестве теоретических работ по применению кейс-метода в процессе обучения математике как в гражданских, так и в военных вузах: не описаны подходы к разработке математического кейса; отсутствуют какиелибо методические рекомендации по организации работы обучающихся с кейсами в ходе учебных занятий.

Авторы научно-методических работ, посвященных данному методу, выделяют различные классификации типов кейсов. Одна из наиболее часто встречающихся классификаций включает следующие кейсы: практический, обучающий, исследовательский [2].

Исходя из содержательных и методических особенностей обучения дисциплине «Математика», краткую характеристику данных типов кейсов представим в виде таблицы.

Таблица 1. Характеристики математических кейсов

\begin{tabular}{|c|c|c|}
\hline \multirow[b]{2}{*}{ Тип кейса } & \multicolumn{2}{|c|}{ Характеристики математического кейса } \\
\hline & Содержание & Краткое описание кейс-задания \\
\hline $\begin{array}{l}\text { Практиче- } \\
\text { ский }\end{array}$ & $\begin{array}{l}\text { Прикладные задачи, в ко- } \\
\text { торых применим аппарат } \\
\text { дисциплины «Математи- } \\
\text { ка» }\end{array}$ & $\begin{array}{l}\text { Формулируется содержательная модель } \\
\text { кейс-задания, в которой может присутство- } \\
\text { вать избыточная информация. Возможно } \\
\text { включение альтернативных ситуаций, из ко- } \\
\text { торых необходимо выбрать оптимальный ре- } \\
\text { зультат. Выполнение кейс-заданий данного } \\
\text { типа осуществляется в рамках одной темы } \\
\text { дисциплины }\end{array}$ \\
\hline Обучающий & $\begin{array}{l}\text { Учебные (условные) ситу- } \\
\text { ации дисциплины «Мате- } \\
\text { матика» }\end{array}$ & $\begin{array}{l}\text { Формулируется содержательная модель } \\
\text { кейс-задания. Приводится список взаимосвя- } \\
\text { занных подзадач, решение которых должно } \\
\text { привести к решению поставленной задачи, } \\
\text { которая в списке занимает последнее место. } \\
\text { Выполнение кейс-заданий данного типа осу- } \\
\text { ществляется в рамках одного раздела дисци- } \\
\text { плины }\end{array}$ \\
\hline $\begin{array}{l}\text { Исследова- } \\
\text { тельский }\end{array}$ & $\begin{array}{l}\text { Исследовательские ситуа- } \\
\text { ции, для решения которых } \\
\text { целесообразно создание } \\
\text { математической модели, } \\
\text { ее исследование и получе- } \\
\text { ние практического вывода }\end{array}$ & $\begin{array}{l}\text { Формулируется содержательная модель } \\
\text { кейс-задания, возможно с избыточной или } \\
\text { недостающей информацией. Задание допус- } \\
\text { кает построение нескольких математических } \\
\text { моделей с использованием знакосимвольных } \\
\text { языков из различных разделов дисциплины }\end{array}$ \\
\hline
\end{tabular}


Так как разработка кейс-задания по математике представляет собой определенные трудности, в качестве примера приведем кейс-задания Интернет-экзамена (компетентностный подход), который проходил в Омском автобронетанковом инженерном институте в 2014 году, и отметим возможные подходы к разработке заданий разных типов.

Задания практического типа: Из круглого бревна радиуса R вытесывается балка с прямоугольным поперечным сечением, основание которого равно $\mathrm{d}$ и высота h. Прочность вытесанной балки пропорциональна величине h3d.

Значение высоты балки, имеющей наибольшую возможную прочность при данном радиусе R, равно ...

Пусть Р0 - прочность балки в случае квадратного поперечного сечения

$(\mathrm{d}=\mathrm{h})$, а Pmax - наибольшая возможная прочность балки при данном радиусе бревна R. Тогда значение выражения $16 \sqrt{3} \frac{P_{\max }}{P_{0}}$ равно ...

Задания обучающего типа: На рисунке изображен график скорости автомобиля $\mathrm{v}(\mathrm{t})$ при его прямолинейном движении для $0 \leq \mathrm{t} \leq 36$, где $\mathrm{t}-$ время с момента старта.

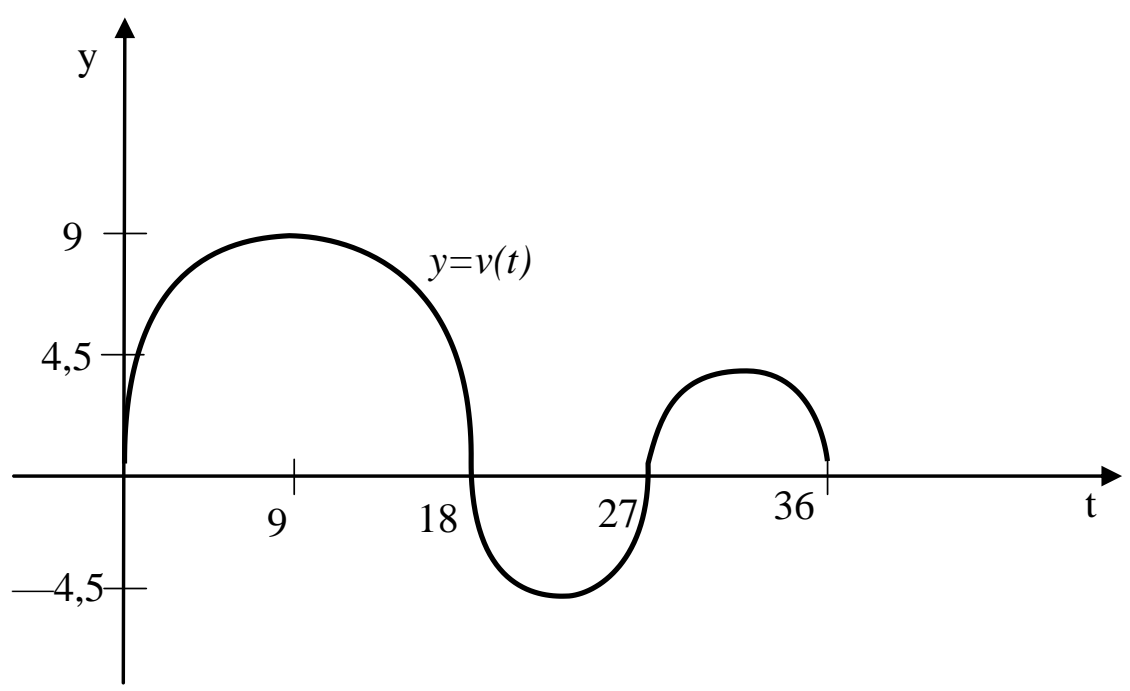

График состоит из трех полуокружностей с радиусами 9; 4,5 и 4,5 соответственно.

1. Пусть А - сумма всех значений $\mathrm{t}$ из отрезка $0 \leq \mathrm{t} \leq 36$, в которых ускорение автомобиля равно нулю. Тогда значение А равно...

2. Пусть В - расстояние, на которое удалился автомобиль за время движения от точки старта. Тогда значение В определяется выражением ...

3. Если В - расстояние, на которое удалился автомобиль за время движения от точки старта, то значение выражения $\frac{2}{\pi}$ В ...

Как видно из приведенных примеров, идеи и содержание кейс-заданий практического типа можно бесконечно черпать из прикладных задач дисциплин естественнонаучного и профессионального циклов.

При разработке обучающих кейс-заданий преподавателю требуется выделить проблемную ситуацию, решение которой опирается на теоретический 
и практический материал предшествующих занятий, но при этом представляющую для обучающихся новизну (по постановке задачи, по способу решения и т.п.). Кейс-задача в обучающем режиме может быть разделена на несколько подзадач, решение которых поэтапно проясняет заданную ситуацию и облегчает ее анализ.

Исследовательские кейс-задания являются заданиями более высокого уровня сложности, однако их содержание и методы решения должны соответствовать уровню подготовки курсантов. Чтобы составить кейс-задание исследовательского типа, необходимо из всего курса математики выделить задания, требующие для своего решения изучения дополнительной информации или привлечения знаний из других разделов математики, дисциплин естественнонаучного и профессионального циклов. Основой для разработки исследовательской кейс-задачи может служить так же содержательная олимпиадная задача.

Кейс-задания всех вышеуказанных типов уже несколько лет включаются в педагогические измерительные материалы (ПИМ) аттестационного тестирования по технологии «Интернет-экзамен в сфере профессионального образования». Поэтому сегодня обучение методике решения данных заданий является актуальной задачей преподавателя вуза.

Работа с кейс-заданиями на всех видах занятий по математике может носить как индивидуальный, так и групповой характер. Кейс-задания практического типа, как правило, ориентированы на индивидуальную работу курсантов и слушателей. Они требуют незначительных временных затрат. Проверка этих заданий не представляет сложности и может осуществляться различными способами: фронтального обсуждения решения с выделением алгоритма действий и проверкой промежуточных ответов, в ходе обсуждения индивидуального решения в выделенных подгруппах с последующим выступлением представителя подгруппы перед аудиторией и т.п.

Кейс-задания обучающего типа вполне доступны курсантам с хорошим уровнем подготовки без дополнительных указаний преподавателя. Для слабо подготовленных курсантов необходимо разработать детальную инструкцию и предусмотреть для них проверку промежуточных результатов. В условиях групповой работы над кейс-заданиями к каждой группе рекомендуется прикрепить консультанта-курсанта с достаточно высоким уровнем математической подготовки. Преподавателю следует организовать с назначенными консультантами предварительное обсуждение заданий кейса в часы консультаций. Для решения кейс-заданий исследовательского типа целесообразно создавать группы не менее шести человек, поэтому задания должны быть или одинаковые, или взаимодополняющие.

Однако следует учитывать, что при решении кейс-заданий любого типа и при любом характере организации работы курсантов и слушателей следует придерживаться определенной методики, которая предполагает:

- анализ ситуации и формулировку проблемы;

- определение возможных методов решения; 
- принятие решения по выбору метода и теоретического инструментария;

- построение математической модели задачи;

- решение проблемы;

- проверка решения на адекватность.

В заключение считаем необходимым отметить, что применение кейсметода в качестве метода интерактивного обучения позволяет формировать у курсантов и слушателей следующие навыки [1]:

Аналитические. К ним можно отнести: умение отличать данные от информации, классифицировать, выделять существенную и несущественную информацию, анализировать, представлять и добывать ее, находить пропуски информации и уметь восстанавливать их. Мыслить ясно и логично.

Практические. Пониженный по сравнению с реальной ситуацией уровень сложности проблемы, представленной в кейс-задании, способствует формированию на практике навыков использования теории, методов и алгоритмов.

Творческие. Одной логикой, как правило, кейс-ситуацию не решить. Очень важны творческие навыки в генерации альтернативных решений, которые нельзя найти логическим путем.

Коммуникативные. Среди них можно выделить следующие: умение вести дискуссию, убеждать окружающих, защищать собственную точку зрения, убеждать оппонентов, составлять краткий, убедительный отчет.

Социальные. В ходе обсуждения кейс-задания вырабатываются определенные социальные навыки: умение слушать, поддерживать в дискуссии или аргументировать противоположное мнение, контролировать себя.

Самоанализ. Несогласие в дискуссии способствует осознанию и анализу мнения других и своего собственного.

\section{Список литературы:}

1. Тривер Т.А., Черникова Н.А. Догматизм противопоказан. Об использовании в учебном процессе технологии анализа конкретных ситуаций // Армейский сборник. № 9. 2005. C. 51-52.

2. Догоруков A. Метод case-study как современная технология профессионально-ориентированного обучения. URL: www.evolkov.net/case/case.study.html

3. Единый портал интернет-тестирования в сфере образования

URL: http://www.i-exam.ru

4. Федеральный Интернет-экзамен в сфере профессионального образования

URL: http: //www.fepo.ru

(C) 2015, Мамаева Н.A., Тривер Т.А., Черникова Н.A. Некоторые аспекты использования кейс-метода в учебном процессе
(C) 2015, Mamaeva N.A., Chernikova N.A., Triver T.A. Some aspects of using of case-method in the learning process 


\title{
Хоружев А.Г. Оценка силовых критериев в системе физической функциональной подготовленности
}

\author{
Horuzhev A.G. \\ Evaluation criteria in the power system \\ of physical functional training
}

Работа посвящена оценке силовой подготовленности у детей и взрослых. $B$ табличном материале даны критерии силовой подготовки, адаптированные под систему физической и функциональной подготовленности Ключевые слова: индекс силы кисти, индекс становой силы, дети, взрослые, студенты, физическая и функциональная подготовленность

\section{Хоружев Анатолий Григорьевич}

Доктор биологических наук, профессор, заведующий кафедрой

Южно-Уральский государственный медицинский университет

г. Челябинск, ул. Воровского, 64
The work is devoted to assessing force readiness in children and adults. In tabular material criteria are strength training, adapted to the system of physical and functional training

Key words: force Index brush, index backbone strength, children, adults, students, physical and functional preparedness

\section{Horuzhev Anatoly Grygorievich}

Doctor of Biological Sciences, Professor, Head of Department

South Ural state medical university

Chelyabinsk, Vorovskogo st., 64

В оценке физической подготовленности человека важная роль отводится силовой подготовки человека, на что указывают многие авторы [1, с.16-17, 2, с. 184-187]. Одним из методов для такого контроля является разработанная в Южно-Уральском государственном медицинском университете (ЮУГМУ) система оценки физической и функциональной подготовленности (ФИФП) [3, с.21-29, 4, с.50-52, 5, с.16-17; 6, с.14-17] ,позволяющая распределять исследуемых на пять групп подготовки

Система ФИФП зарекомендовала себя для проведения массовых тестирований детей и студентов. Для этого в системе ФИФП предусмотрено 36 тестов, из которых отбираются для оценки ФИФП только 8 в зависимости от условий тестирования.

Система ФиФП выделяет пять групп физической и функциональной подготовки:

1-я группа - лица с очень плохой подготовкой (от - 21 до+28 баллов);

2-я группа - лица с плохой подготовкой (29 - 68 баллов);

3-я группа - лица с удовлетворительной подготовкой (69-109баллов);

4-я группа - лица с хорошей подготовкой (110 - 149 баллов); 
5-я группа - лица с отличной подготовкой (150 и более баллов).

При массовых тестированиях студентов и школьников, как правило, для оценки силовых критериев берется оценка индекса силы кисти, суммарного силового критерия и индекса становой силы [3, с.21-29, 4, с.50-52, 5, с.16-17].

Нами разработаны оценки индекса силы кисти (таблица № 1,2). Оценка суммарного силового критерия приводится в нашей работе [3, с.21-29]. Для решения разработки силовых критериев было протестировано 4000 лиц разного возраста, для отработки методики оценки становой силы - 650 детей и подростков.

Задача настоящей работы обратить внимание на оценку индекса становой силы, так как он более информативен, но необходим особый подход к методике его применения. Он требует больше время на тестирование, не у всех имеются в достатке надлежащие становые динамометры. Но самое главное особенности техники по определению становой силы. При проведении медицинских осмотров используется повсеместно классический метод оценки становой силы [4, с.50-52, 7, с. 77-80]: туловище сгибают, ноги выпрямлены, цепь закрепляют за крюк так, чтобы рука от прибора находилась на уровне колен; тяга выполняется спиной - способ (а). В последнее время появилось множество исследований и работ, рассматривающих элементы биомеханики позвоночника при различных упражнениях, которые ведут к перегрузкам и травмам тканей позвоночника. Обращает на себя внимание, что в положение наклона диски позвоночника испытывает наибольшие нагрузки. Особенно опасной для получения травм становится нагрузка, выполняемая без разминки. Разминку в процессе массовых тестирований делать для всех нет возможности, а нагрузка предлагается максимальная.

Нами сделана попытка в решении отдельных фрагментов этой глобальной проблемы в работе [8, с.174-176]. В исследовании сравнивали оценку становой силы классическим способом (a) с предложенным нами при поднятии тяжести приседом, не наклоняясь, с сохранением поясничного лордоза (способ б). Учитывая данные рекомендации при испытании становой силы, мы стали ее оценивать и проводить из положения полуприседа, где угол между бедром и голенью составляет 90-95 градусов, с сохранением поясничного лордоза (напоминает положение штангиста при подъеме штанги, но при боле высокой стойке, а гриф динамометра регулируется по уровню колен) - способ (б).

Таблица 1. Оченка индекса силы кисти у взрослых

\begin{tabular}{|c|c|c|c|}
\hline & \multicolumn{3}{|c|}{ Величина показателя - Fк ** } \\
\hline Мужчины & Женщины & Баллы & Оценка результата \\
\hline 8,81 и $>$ & $6,82>$ & 18 & Очень высокий \\
\hline $8,80-8,31$ & $6,81-6,01$ & 14 & Высокий \\
\hline $8,30-7,81$ & $6,00-5,20$ & 10 & Выше среднего \\
\hline $7,80-6,82$ & $5,19-4,39$ & 6 & Средний \\
\hline $6,81-6,32$ & $4,38-3,58$ & 2 & Ниже среднего \\
\hline $6,31-5,82$ & $3,57-2,77$ & 0 & Низкий \\
\hline 5,81 и $<$ & 2,76 и < & -2 & Очень низкий \\
\hline
\end{tabular}

Примечание: ${ }^{* *}-F \kappa=(F \mathcal{N}+F n) \times 10: 2 P$, где - Р вес тела в кг; Fл, Fn - сила левой и правой рук 


\begin{tabular}{|c|c|c|c|c|c|}
\hline \multicolumn{7}{|c|}{ Величина показателя - Fк ** } \\
\hline \multicolumn{2}{|c|}{ Возраст 10-12 лет } & \multicolumn{2}{|c|}{ Возраст 13-16 лет } & Баллы & Оценка результата \\
\hline Мальчики & Девочки & Мальчики & Девочки & & \\
\hline 6.89 и > & 5,99 и $>$ & 6,99 и > & 5,99 и > & 18 & Очень высокий \\
\hline $6,88-6,32$ & $5,98-5,56$ & $6,98-6,44$ & $5,98-5.56$ & 14 & Высокий \\
\hline $6.31-5,75$ & $5,55-5,13$ & $6,43-5,89$ & $5,55-5.13$ & 10 & Выше среднего \\
\hline $5,74-5,18$ & $5.12-4,69$ & $5,88-5,34$ & $5,12-4,69$ & 6 & Средний \\
\hline $5,17-4,61$ & $4,68-4,26$ & $5,33-4,79$ & $4.68-4,26$ & 2 & Ниже среднего \\
\hline $4,6-4,04$ & $4.25-3,83$ & $4,78-4,24$ & $4,25-3.83$ & 0 & Низкий \\
\hline 4,03 и < & 3,82 и < & 4,23 и $<$ & 3.82 и $<$ & -2 & Очень низкий \\
\hline
\end{tabular}

Результаты исследований показали во всех случаях преимущество способа (б). После выполнения становой силы классическим методом (а) от 20 до $25 \%$ детей и подростков указывают на неприятные ощущения и даже боли в области позвоночника. В данном случае в поясничном отделе позвоночника происходит сильное сгибание, следовательно, на переднюю часть межпозвоночного диска действуют сжимающие, а на заднюю часть - растягивающие нагрузки. Давление, приходящееся на единицу поверхности диска, оказывается при этом очень большим. Это вызывает, естественно, неприятные ощущения и объективно становится серьезным фактором риска получить перегрузку. При втором способе (б) обследуемые не указывали на болезненные ощущения в области позвоночника несмотря на то, что результат силы в данном положении был выше на 5-10\% от испытания (а). Чтобы внедрить данную методику на практике, нам необходимо было разработать оценочные критерии для способа (б), так как возрастных таких критериев нет.

Информация о силовых способностях детей, как занимающихся, так и не занимающихся спортом, необходима. Развитию силы уделяют особое внимание в своих тренировочных циклах большинство атлетов. Огромные нагрузки испытывает позвоночник не только при поднятии штанги, но и во время бросков в борьбе, прыжках, метаниях и многих других динамических и статических упражнениях. Профилактике заболеваний и травм позвоночника специалистами медицины уделяется особое внимание. Позвоночник является важным звеном опорно-двигательного аппарата человека. Он не только предохраняет спинной мозг, но и принимает активное участие во всех сложных и многообразных действиях, несет огромную статическую и динамическую нагрузку. Проблема настолько актуальна, что требует объединенных усилий врачей, тренеров, преподавателей физической культуры и спортсменов в решении вопросов профилактики и лечения заболеваний позвоночника. В таблице №3,№4 приведены данные оценки силы с учетом веса тела, индексным методом.

Оценка индекса становой силы поводится по формуле:

$$
\text { Индекс Fстан = (Fстановая + 0,9Fстановой }) \times 10: 2 \mathrm{P}
$$

где Р- вес тела в кг; F- становая сила.

Пример юноша 16 лет, вес 52 кг, становая сила 110 кг. Данные подставляем в формулу - индекс $\mathrm{F}=(110+99)$ х 10: 104=20,09

Индекс становой силы будет равен 20,09. По таблице №4 смотрим, что для юноши 16 лет это относится к оценке « средний»и соответствует 10 бал- 
лам. В дальнейшем эта оценка входит в общую сумму баллов ФИФП и определению "двигательного возраста". Такие комплексные оценочные критерии разработаны нами для всех видов испытаний как для нетренированных, так и занимающихся спортом детей и взрослых.

Таблица 3. Оченка индекса становой силы у взрослых

\begin{tabular}{|c|c|c|c|}
\hline \multicolumn{4}{|c|}{ Величина показателя - F становой ** } \\
\hline Мужчины & Женщины & Баллы & Оценка результата \\
\hline 23,0 и $>$ & 21,5 и $>$ & 22 & Очень высокий \\
\hline $22,9-21,7$ & $21,4-20,2$ & 18 & Высокий \\
\hline $21,6-20,4$ & $20,1-18,8$ & 14 & Выше среднего \\
\hline $20,3-17,9$ & $18,7-16,1$ & 10 & Средний \\
\hline $17,8-16,6$ & $16,0-14,7$ & 6 & Ниже среднего \\
\hline $16,5-15,3$ & $14,6-13,3$ & 2 & Низкий \\
\hline 15,2 и $<$ & 13,2 и $<$ & -2 & Очень низкий \\
\hline
\end{tabular}

Примечание: ${ }^{* *}$ Fстановая = (Fстановая +0,9Fстановой $) \times 10: 2$, где Р - вес тела в кг;

$F$ - становая сила

Таблица 4. Оценка индекса становой силы у детей и подростков

\begin{tabular}{|c|c|c|c|c|c|}
\hline \multicolumn{6}{|c|}{ Величина показателя - F становой ** } \\
\hline \multicolumn{2}{|c|}{ Возраст 10-12 лет } & \multicolumn{2}{|c|}{ Возраст 13-16 лет } & \multirow{2}{*}{ Баллы } & \multirow{2}{*}{ Оценка результата } \\
\hline Мальчики & Девочки & Мальчики & Девочки & & \\
\hline 23,3 и > & 18,5 и > & 24,2 и > & 18,1 и > & 22 & Очень высокий \\
\hline $23,2-21,7$ & $18,4-17,4$ & $24,1-22,4$ & $18-17$ & 18 & Высокий \\
\hline $21,6-20,1$ & $17,3-16,3$ & $22,3-20,6$ & $16,9-15,9$ & 14 & Выше среднего \\
\hline $20-17$ & $16,2-14,2$ & $20,5-17,1$ & $15.8-13.8$ & 10 & Средний \\
\hline $16,9-15.4$ & $14,1-13,1$ & $17-15,3$ & $13.7-12,7$ & 6 & Ниже среднего \\
\hline $15,3-13,8$ & $13-12$ & $15,2-13,5$ & $12,6-11,6$ & 2 & Низкий \\
\hline 13,7 и $<$ & 11,9 и $<$ & 13,4 и $<$ & 11.5 и < & -2 & Очень низкий \\
\hline
\end{tabular}

Методы являются информативными и могут быть рекомендованы в практику массовых обследований. Измерение становой силы эффективнее поводить не классическим способом (а), а способом (б) - тяга ногами, не создающая опасности получения перегрузки и травм позвоночника.

\section{Список литературы:}

1. Чоговадзе А.В., Круглый М.М.Врачебный контроль в физическом воспитании и спорте. Москва:

Медицина, 1977. 175 с.

2. Зациорский В.М. Спортивная метрология. М.: ФиС.,1982. 256 c.

3. Хоружев А.Г. Методы оценки физической работоспособности и функционального состояния сердечно-сосудистой системы в медицине и физиологии. Челябинск: Форум-издат, 1993. 96 с.

4. Хоружев А.Г. Тестовый контроль в системе оценки физической и функциональной подготовленности, работоспособности и «двигательного возраста» лиц старше 17 лет. Челябинск: Южно-Уральского государственного медицинского университета, 2014. $60 \mathrm{c.}$

5. Хоружев А.Г., Мыльников В.В., Мурашова В.П. Оценка физической подготовленности, функционального состояния, двигательного возраста и умственной работоспособности у детей и подростков. Челябинск, 2008. 35 с.

6. Хоружев А.Г. Критерии нормы и патологии функционального состояния и физической подготовленности человека в постнатальном онтогенезе от 3 до 65 лет: автореф. дис. ... д-ра биол. наук. Челябинск, 1994. 50 с. 
7. Иванов С.М. Врачебный контроль и лечебная физкультура. Москва: Медицина, 1970. 472 с.

8. Хоружев А.Г., Мурашова В.П., Мыльников В.В., Степанов С.В. О разработке критериев оценки становой силы у детей и подростков // Здравостроение. Теория здоровья и здорового образа жизни. Челябинск, 2005. С. 174-176.

\section{References:}

1. Chogovadze A.V., Krugly M.M. Medical control in physical education and sport. Moscow: Medicine, 1977. $175 \mathrm{p}$.

2. Zatsiorsky V.M. Sport metrology. M.: FiS., 1982. 256 p.

3. Horuzhev A.G. Methods of assessing physical performance and functional state of the cardiovascular system in medicine and physiology. Chelyabinsk: Forum-izdat, 1993. 96 p.

4. Horuzhev A.G. Test control in the evaluation of physical and functional readiness, efficiency and "motor age" of persons older than 17 years. Chelyabinsk: Publishing South Ural State Medical University, 2014. 60 p.

5. Horuzhev A.G., Myl'nikov V.V., Murashova V.P. Evaluation of physical fitness and functional status, the age of the motor and mental performance in children and adolescents: a scientific publication. Chelyabinsk, 2008. $35 p$.

6. Horuzhev A.G. Criteria normal and pathological functional status and physical fitness of human postnatal ontogenesis from 3 to 65 years: the dissertation author's Dr. biol. Sciences. Chelyabinsk, 1994. 50 p.

7. Ivanov S.M. Medical supervision and physiotherapy. Moscow: Medicine, 1970. 472 p.

8. Horuzhev A.G., Murashova V.P., Myl'nikov V.V., Stepanov S.V. On the development of criteria for evaluating postural strength in children and adolescents //Zdravostroenie. The theory of health and healthy lifestyle.

Chelyabinsk, 2005. Pp. 174-176.

(C) 2015, Хоружев А.Г.

Оценка силовых критериев в системе физической функциональной подготовленности
(C) 2015, Horuzhev A.G.

Evaluation criteria in the power system of physical functional training 


\title{
Ширина Т.Г. \\ Современные тенденции развития высшего образования: от европейского к международному измерению
}

\author{
Shirina T.G. \\ Current trends of higher education development: \\ from European to international dimension
}

В данной статье рассмотрены современные тенденции развития высшего образования, характеризующие усиление научнообразовательной и исследовательской деятельности в современной поликультурной среде и обуславливающие переход от европейского измерения кмеждународному

Ключевые слова: глобализация, глобализация культуры, интернационализация, европейское измерение, международное измерение

\section{Ширина Татьяна Геннадьевна}

Ассистент

Новгородский государственныйуниверситет им.

Ярослава Мудрого

Великий Новгород, ул. Большая Санкт-

Петербургская, 41

\begin{abstract}
This article concerns current trends of higher education development that characterize growth of academic and exploratory activity in modern multicultural environment and determine the move from european dimension to international dimension
\end{abstract}

Key words: globalization, culture globalization, internationalization, european dimension, international dimension

\author{
Shirina Tatjana Gennadjewna \\ Assistance \\ Novgorod state university of Yaroslav Mudriy \\ Veliky Novgorod, B. St. Petersburgskaya st., 41
}

Изменившиеся социально-экономические и политические условия, возрастающая зависимость стран друг от друга и усиливающаяся роль международных организаций создали совершенно новый контекст развития системы высшего образования. Возрастающая значимость высшего образования, как движущей силы экономического роста в глобальном контексте, проявляется в создании единого мирового образовательного пространства, на уровне которого наблюдается рост культурного разнообразия.

В связи с развитием мирового образовательного пространства, актуальными являются такие его характеристики, как «глобализация», «интернационализация», «европейское измерение», «международное измерение». Каждый из этих терминов подчеркивает разные тенденции в развитии современного высшего образования, объединяя их стремление показать единство высшего образования на глобальном уровне, а также усиление международной научно- 
образовательной и исследовательской деятельности в современной поликультурной среде, характеризующейся разнообразием и взаимозависимостью.

Однако при подробном изучении вышеприведенных понятий, современные исследователи дают неоднозначные их трактовки и оценки. Так, по мнению М.М. Акулич: «глобализация - это сложный и противоречивый процесс». Автор выделяет оптимистический, пессимистический и нейтральный подходы к оценке данного процесса: «Оптимисты исходят из того, что глобализация это неизбежный феномен, объективно обусловленный, имеющий в основном позитивную направленность и перспективы. Однако пессимисты обращают внимание на негативные последствия глобализации, неготовность многих государств к участию в этом процессе. По их мнению, национальная специфика «заглушается» неодолимой силой рынка, глобализация не привязана к прошлому, к традициям страны» [1, с.53].

Мы разделяем точку зрения Акулич М.М. в той позиции, что наступил такой момент исторического развития мировой сферы высшего образования, когда национальная обособленность вузов вступает в конфликт с последствиями и перспективами глобализации экономики: вопросы в признании университетских дипломов и специализаций, развитии международных форм оценки качества, процедурах международной аккредитации и т.д. Решение этих вопросов как раз отражается в таких формах глобализации высшего образования, как: мобильность студентов и преподавателей, интернационализация учебных планов, международные образовательные программы и др.

Рассматривая процесс глобализации как одну из тенденций развития современного высшего образования, стоит также обратить внимание на феномен «глобализация культуры». Глобализацию культуры А.И. Кравченко раскрывает как «ускорение интеграции наций в мировую систему, в связи с развитием современных транспортных средств и экономических связей; формированием транснациональных корпораций и мирового рынка, благодаря воздействию на людей средств массовой информации» [2, с.117]. Термин «глобализация культуры» появился в конце 80-х гг., в связи с проблемой сближения наций и расширением культурных контактов народов. Глобализация культуры также имеет позитивные и негативные стороны. Расширение культурных контактов в современном мире, общение и познание способствует сближению народов. Однако чрезмерно активное заимствование опасно потерей культурной идентичности. Открытость границ для культурного влияния и расширяющееся культурное общение могут привести, с одной стороны, к обмену положительным опытом, обогащению собственной культуры, подъему ее на более высокую ступень развития, с другой - к ее культурному истощению за счет унификации и стандартизации, распространения одинаковых культурных образцов всему миру [2, с.118].

Таким образом, процесс глобализации нельзя определить в исключительно позитивном или в исключительно негативном влиянии на развитие высшего образования. В современных условиях вузы стремятся к нахождению баланса между сохранением собственных академических традиций и приобретением нового опыта в процессе международного сотрудничества, которое 
необходимо для укрепления своих позиций в мировом академическом сообществе. Только тщательно продуманная стратегия развития вуза, учитывающая актуальные мировые тенденции и использующая преимущества конкретного университета, может способствовать его дальнейшему успеху на образовательном рынке. В этом плане такая стратегия является результатом не только глобализации, но и интернационализации высшего образования. В реальной практике современного вуза эти процессы являются тесно взаимосвязанными.

В отличие от глобализации, интернационализация университетов не является новым явлением. Высшее образование всегда было проникнуто духом интернационализма и межнационального сотрудничества. Идеи интернационализации искусства, науки и образования зародились уже в XVII в., когда средневековые студенты странствовали от Болоньи до Парижа и Оксфорда. На рубеже XX - XXI веков интернационализация протекает в жестких условиях глобализации мирового образовательного пространства. Поэтому некоторые авторы, считая глобализацию и интернационализацию высшего образования явлениями разного порядка (явлением глобальной мировой экономики и явлением культуры) в современных условиях рассматривают межкультурное взаимодействие современных систем образования - интернационализацию высшего образования - одним из проявлений глобализации. На наш взгляд, глобализация не является явлением лишь глобальной мировой экономики, но и неизбежно распространяется на сферу культуры, образования и др.

Несмотря на то, что в условиях глобализации национальные границы становятся менее явными, культурные особенности не только не уменьшаются, а наоборот возрастают. Современные споры об интернационализации высшего образования связаны с ее культурным аспектом. Поэтому вопрос интернационализации - это вопрос интеркультурализма высшего образования.

Сегодня интернационализация выступает как «активное и эффективное межстрановое сотрудничество с целью взаимообогащения и обмена опытом в сфере образования» [3, с.126] и затрагивает фундаментальные основания высшей школы как социального института. Идея интернационализации предполагает определенный универсализм в образовании; «процесс превращения национального вуза в интернациональный вуз, ведущий к включению международного аспекта во все компоненты комплексного управления с целью повышения качества преподавания и исследования, а также достижения требуемых компетенций» [4, с.193].

По мнению Вербицкой, преимущества интернационализации в высшем образовании очевидны: это объединение ресурсов, в особенности, когда они так труднодоступны, как сейчас: избежание дублирования и ненужного копирования тем исследования; лучшая идентификация проектов и растущая уверенность в их целесообразности в условиях коллективного надзора. Интернационализация углубляет базу знаний институтов участников, раздвигает рамки научного поиска, обогащает учебные программы. Присутствие в вузе студентов и ученых из разных стран расширяет культурные горизонты, как студентов, так и преподавательского состава своей страны. Обучение иностран- 
ных студентов влияет на развитие их стран и способствует глобальной экономической и политической стабильности [5, с.16].

Изменившиеся социально-экономические и политические условия, возрастающая зависимость стран друг от друга и усиливающаяся роль международных организаций создали совершенно новый контекст развития системы высшего образования в европейских странах. Одним из проявлений влияния этих условий на развитие вузов является Болонский процесс, который вполне уместно оценить в историческом плане как беспрецедентно масштабный и глубокий. Как известно, основная цель Болонской декларации - формирование единого Европейского пространства высшего образования, в основе которого лежат институциональная автономия, академическая свобода, равные возможности и демократические принципы - все, что способствует мобильности, увеличению занятости и улучшению привлекательности и конкурентоспособности высшего образования Европы. Следует отметить, что в основе принципов Болонской декларации лежит принцип «единства в многообразии». Общность модели высшего образования при сохранении многообразия означает вероятность создания в перспективе «европейского университета без границ», а также усиление европейского измерения в современных культурных условиях. Особый интерес в рассмотрении тенденций в развитии современного высшего образования, помимо глобализации и интернационализации вызывает достаточно распространенный в общественно-политической и специальной литературе феномен «европейское измерение» [6].

Европейское измерение нацелено на выравнивание уровня образования различных стран, но не ставит перед собой задачу создания наднациональной, единой для всей Европы образовательной системы. При таком подходе исключается вмешательство в образовательную деятельность отдельных стран и вузов. Основной задачей согласованной образовательной политики становится содействие достижению высокого качества образования посредством организации сотрудничества, оказание им поддержки в их образовательной деятельности в условиях культурного и языкового разнообразия, а также содействие обмену международным научно-образовательным опытом в рамках единого Европейского пространства.

Европейское измерение, как отмечают С.Р. Агирбов, С.А.Сказко: «придает знаниям, убеждениям и ценностям новый глобальный ракурс, который позволяет участникам международных образовательных программ взглянуть на себя не только как на часть страны или этноса, но ощутить свое единство с мировой и европейской цивилизацией» [7, с. 96].

Немецкий исследователь Bettina Motschmann [8, с.42], выделяет два уровня европейского измерения: объективно-административный уровень, предполагающий создание сети европейских культурно-образовательных и научных институтов, призванных транслировать Европейские ценности в глобализированном пространстве и оказывать содействие национальным образовательным системам в проведении так называемых «европейских студий», направленных на изучение культуры, истории, географии Европы, а также проведение исследований в этих областях знаний; субъективно-ментальный уровень, 
предполагающий формирование чувства европейской общности, основанного на едином понимании европейских ценностей, а также стремлении осуществлять научный обмен идеями, ресурсами, группами студентов и преподавателей. Чувство европейской общности является мотивирующим фактором, обеспечивающим участие в международных образовательных программах и программах академических обменов. Результатом такого опыта становится углублённое понимание других культур и обогащение собственной культуры.

В условиях интернационализации, с учетом глобализации экономики, культуры и высшего образования, специфики развития международной деятельности вузов и участия в международных образовательных программах, как преподавателей, так и студентов всего мира, опираясь на определение «европейского измерения» считаем необходимым обозначить понятие «международного измерения», которое трактуется нами как наличие ярко выраженной международной составляющей во всех компонентах образовательного процесса в вузе, приближающей его к международным стандартам и придающей ему поликультурную направленность. Международные образовательные стандарты не являются нормативным документом, а скорее своего рода метафорой, которая отражает качественные характеристики высшего образования, соответствующие неким эталонам, признанным на международном уровне. Международные стандарты являются важным источником для организации непрерывного образования. Они ни в коей мере не заменяют национальные образовательные стандарты, которые отражают совокупность конкретных требований, предъявляемых в различных странах к уровню подготовки выпускников образовательных учреждений различного типа, а отражают мировые тенденции развития образования, и, избегая конкретизации и детализации, задают вектор развития непрерывного образования [9,с. 72].

Нами было выделено три уровня международного измерения: содержательно-технологический, структурно-содержательный и организационноуправленческий. На содержательно-технологическом уровне международное измерение предполагает включение в учебные программы модулей или модульных элементов, отражающих инновационный зарубежный опыт в области науки, техники, культуры, высшего и среднего образования, а также результаты компаративистских исследований в различных областях знаний. Международное измерение предполагает внедрение в образовательный процесс различных технологий и методов, отражающих достижения современной дидактики в различных странах мира, включая методики смешанного и дистанционного обучения, позволяющие осуществлять виртуальную межкультурную коммуникацию, а также технологии инклюзивного образования, обеспечивающие открытость и доступность образовательных ресурсов различным гетерогенным группам обучающихся.

На структурно-содержательном уровне международное измерение предполагает внедрение в систему высшего образования принципов Болонской декларации, создание и реализацию совместных образовательных программ, в том числе и с двойным дипломом, распространение различных форм глобаль- 
ного образования (транснациональное образование, франчайзинг, филиалкампус, корпоративное соглашение и др.).

На организационно-управленческом уровне международное измерение предполагает аккумуляцию финансовых, административных, материальных и кадровых ресурсов, обеспечивающих международную составляющую образовательного процесса. К этому уровню относятся также установление договорных отношений с вузами партнерами, развитие стратегического международного партнерства и других видов международного сотрудничества в контексте интернационализации высшего образования.

Таким образом, рассматривая «глобализацию» и «интернационализацию» в качестве основных тенденций развития современного высшего образования, с учетом стремительного развития международной деятельности вузов и участия в международных образовательных программах студентов и преподавателей не только стран Европы, но и всего мира, актуальным становится переход от европейского к международному измерению, обеспечивающему качество высшего образования мирового уровня.

\section{Список литературы:}

1. Акулич М.М. Образование в условиях глобализации // Университет. Управление: практика и анализ. 2005. №5 (38). C. 50-58.

2. Кравченко А.И. Культурология: Словарь. М.: Академический проект, 2000. С. 117-118.

3. Горбунова Е.М., Ларионова М.В. Интернационализация высшего образования в странах ОЭСР // Актуальные вопросы развития образования в странах ОЭСР. М.: Издательский дом ГУ ВШЭ, 2005. $152 \mathrm{c.}$

4. Елкина А.С. Интернационализация образовательных услуг вуза в современных условиях // Вестник Волгоградского государственного университета. Серия 3: Экономика. Экология. 2009. №1. С. 192-198.

5. Вербицкая Л.А. Глобализация и интернационализация в образовании и важность изучения иностранных языков // Мир русского слова. 2001. №2. С. 15-18.

6. Гусев А.А. Европейское измерение в образовании стран ЕС.

URL: www.viperson.ru/prnt.php?prnt $=1 \& I D=543462$

7. Агирбов С.Р., Сказко А.С. К вопросу об интернациональном воспитании в вузе // Научноисследовательские публикации. №4(8) 2014. С. 96.

8. Bettina Motschmann. Die Umsetzung der «europäischen Dimension» in der Lehrerbildung // Im Fachbereich Erziehungswissenschaften der Universität Lüneburg vorgelegte Dissertation zur Erlangung des Grades Doktorin der Philosophie, 2001.

9. Концепции и стратегии непрерывного образования в международном контексте: сборник материалов международного форума. СПб.: СПб АППО, 2012. 309 с.

(C) 2015, Ширина Т.Г.

Современные тенденции развития высшего образования: от европейского к международному измерению
(C) 2015, Shirina T.G.

Current trends of higher education development: from European to international dimension 


\title{
Ширин Д.А. \\ Интернет-маркетинг как современный инструмент обеспечения взаимодействия субъектов образовательного процесса
}

\author{
Shirin D.A. \\ Internet-marketing as contemporary instrument that provides \\ cooperation of subjects of educational process"
}

В данной статье рассматривается интернетмаркетинг как современный инструмент обеспечения взаимодействия субъектов образовательного процесса, а также содержательное наполнение официального Webсайта современного вуза

Ключевые слова: интернет-маркетинг, Web-caŭm вуза, интернет-сообщество

\section{Ширин Дмитрий Александрович}

Аспирант

Новгородский государственный университет им.

Ярослава Мудрого

Великий Новгород, ул. Большая Санкт-

Петербургская, 41
The article considers Internet-marketing as contemporary instrument that provides cooperation of subjects of educational process, and informal content of official Web-site of modern higher education institutions

Key words: internet-marketing, Web-site of higher education institutions, Web-community

\author{
Shirin Dmitry Alexandrovich \\ Postgraduate \\ Novgorod state university named Yaroslav Mudriy \\ Veliky Novgorod, B. St. Petersburgskaya st., 41
}

В рамках сложившихся экономических и информационнотехнологических условиях, благосостояние вузов все больше зависит от своих собственных усилий и умения создавать и предоставлять актуальные образовательные услуги. Современному вузу необходимо акцентировать свое внимание не только на потребителя, но и на других партнеров и контактные аудитории. Это обуславливает необходимость применения в деятельности вузов современных инструментов маркетинга, одним из видов которого является интернет-маркетинг. Под термином Интернет-маркетинг понимается теория и методология организации маркетинга в гипермедийной среде Интернета, который обладает уникальными характеристиками, значительно отличающимися от характеристик традиционных инструментов маркетинга. Одним из основных свойств среды Интернета является ее гипермедийная природа, характеризующаяся высокой эффективностью в представлении и усвоении информации, что значительно повышает возможности маркетинга в усилении взаимосвязи предприятий и потребителей [1, с.23]. 
На сегодняшний день одним из современных средств информирования о деятельности университета выступает официальный веб-сайт вуза. С точки зрения Интернет-маркетинга, WEB-сайт - это набор информационных блоков и инструментов для работы с одним или несколькими сегментами целевой аудитории. Какая информация будет представлена на нем, какие инструменты будут задействованы, как они будут взаимодействовать между собой - все это зависит от выбранной вузом стратегии продвижения образовательных услуг, краткосрочных и долгосрочных задач, а также от типа сегментов целевой аудитории и возможностей контактировать с ней. WEB-сайт может построить отношения с потребителями и членами профессионального сообщества, посещающими Интернет, намного лучше, чем большинство других видов маркетинговых коммуникаций, поэтому Интернет-составляющая выступает как часть стратегии развития вуза [2, с. 43].

Интернет-маркетинг в университетах можно представить несколькими позициями:

- несомненно, сайт самого университета и проблема его продвижения;

- подсайты и подразделы главного сайта образовательных подразделений;

- электронная почта, сети - здесь процесс набирает силы;

- дистанционное обучение;

Рассмотрим, определение «Web-сайт вуза», его цель и функции, а также содержательное наполнение Web-сайта современного вуза.

Под официальным Web-сайтом вуза A.B. Полтавец понимает «принадлежащий вузу веб-сайт, предназначенный для всестороннего и достоверного информирования (от имени руководства) внешних и внутренних посетителей о деятельности вуза, а также представляющий посетителям сайта всю необходимую для обеспечения взаимодействия с вузом, его руководством или его подразделениями справочную информацию» [3].

Целью образовательного Web-сайта вуза является создание информационно-коммуникационного пространства для поставщиков и потребителей образовательных услуг определенного сегмента рынка посредством Интернета, что предоставляет новые возможности получения и усовершенствования знаний и навыков, а также управления образованием [4, с.12].

Принимая во внимание определение и цель веб-сайта современного вуза, можно выделить его четыре основные функции:

- Информационная - обеспечение и распространение актуальных и важных сведений о функционировании вуза (его приоритетных направлениях, образовательных услугах, кадровом составе, успехах и наградах и т.д.);

- Коммуникативная - обеспечение взаимодействия администрации, партнеров, преподавателей, студентов и абитуриентов (форумы, вебинары, онлайн-конференции, профессиональные сообщества);

- Ресурсная - обеспечение доступа аудитории (ППС, персонал, студенты) к получению и использованию различных средств (информации) для реализации их профессиональной и образовательной деятельности; 
- Имиджевая - формирование благоприятного отношения к университету как к конкурентоспособному учебному заведению, предоставляющему актуальное, доступное и качественное образование (наличие научной школы, партнерских отношений, работодателей, перспективных внешних связей).

Теперь обратимся непосредственно к содержательной наполняемости и техническим возможностям современного веб-сайта вуза. Для успешного функционирования университетского веб-сайта недостаточно только следовать критериям его содержательной наполняемости. Так, например, среди существующих веб-сайтов вузов есть и те, которые не обладают информационной насыщенностью согласно выделенным критериям в полной мере, но пользуются популярностью среди преподавательского и студенческого состава, в то время как у других вузов, при высочайшем уровне наполнения площадки веб-сайта контентом, уровень глубины просмотров гораздо ниже. Причиной популярности веб-сайта заключается в грамотном обеспечении пользователей не пассивной, а активной коммуникацией. Веб-сайт университета должен социализироваться в Интернет-сообществе, а именно: проявить себя в крупнейших социальных отечественных и иностранных сетях; привлечь своих преподавателей и студентов к формированию актуального контента; использовать современные методы привлечения целевой аудитории (поисковая оптимизация, маркетинг в социальных сетях, контекстная реклама). Придать комплексность и системность этому процессу способен специальный отдел вуза (служба поддержки). Служба поддержки университетского сайта, помимо технических задач, должна организовать процесс перспективного планирования развития сайта, искать и исследовать новые формы, технологии и методы работы с потребностями и интересами целевой аудитории, способствовать развитию виртуальных коммуникаций у пользователей сайта. Преимущества веб-сайта как средства для реализации эффективных коммуникаций связаны с его общедоступностью, низкой материальной стоимостью и маневренностью (легкостью и скоростью внесения изменений).

Одним из существенных аспектов функционирования информационного ресурса может служить создание условий для осуществления обратной связи, т.е. оптимального для всех участников взаимодействия (со стороны университета, руководства, персонала) и целевых аудиторий (родители, студенты, абитуриенты). К инструментам, используемым для данных целей, можно отнести форумы, опросы, рейтинги, ответы на вопросы, пользующиеся стабильным спросом.

Учитывая, что веб-сайт является эффективным инструментом взаимодействия преподавателей и студентов, каждый пользователь должен быть уверен в конфиденциальности размещаемых материалов и информации, поэтому необходимо принять во внимание такой важный аспект как создание «личных кабинетов». Таким образом, преподаватели могут организовать способы доступа к тем или иным учебным материалам для отдельных групп или студентов. Каждый студент может в режиме реального времени проследить свою успеваемость и спланировать выполнение контрольных и тестовых заданий в удобное для себя время. Эффективное сетевое взаимодействие препода- 
вателя и студента в учебное и внеучебное время позволит каждому студенту, находясь дома или в вузе, получать качественные консультации и дополнительные материалы для подготовки (форумы, чаты и видеоконференции, вебинары), а сохранение истории переписки позволит накапливать знания. Кроме того, наличие электронных публикаций книг, пособий и других информационных материалов приносит наибольший эффект, так как охват читателей увеличивается по сравнению с печатными публикациями. Таким образом, вебсайт может также выступать виртуальной площадкой профессиональных образовательных сообществ.

Подводя итог вышесказанному, веб-сайт вуза способен не только обеспечивать участников образовательного процесса необходимой информацией и организовывать взаимодействие посетителей сайта путем виртуальной коммуникации, но и стать инструментом изучения интересов и предпочтений целевой аудитории, своевременно формируя и корректируя вузовские образовательные стратегии. Официальный веб-сайт вуза как современный инструмент обеспечения информационной деятельности имеет непрерывный характер развития, должен наполняться в зависимости от постоянно меняющихся информационных технологий и внешней среды. Таким образом, использование вузом интернет-маркетинга, обуславливающего развитие веб-сайта вуза, с учетом выделенных функций, позволяет не только отслеживать и своевременно реагировать на новые информационно-технические требования, но и обеспечивать активное взаимодействие субъектов образовательного процесса.

\section{Список литературы:}

1. Успенский И.В. Интернет-маркетинг. СПб.: СПГУЭиФ, 2003. 197 с.

2. Даниленко Л.В. Маркетинг и реклама образовательных учреждений // Материалы семинара.

М.: Московская Бизнес Школа, 2008. 101 с.

3. Полтавец А.В. Веб-сайт вуза как эффективный инструмент обеспечения вузовской деятельности // Вопросы управления. 2010.

URL: http://vestnik.uapa.ru/ru-ru/issue/2010/03/03/

4. Домнич А.А. Принципы разработки сайта учебного заведения с учетом критериев эргономичности // Восточно-Европейский журнал передовых технологий. №2(49).

T. 1. 2011. C.11-14.

(C) 2015, Ширин Д.А.

Интернет-маркетинг как современный инструмент обеспечения взаимодействия субъектов образовательного процесса
(C) 2015, Shirin D.A.

Internet-marketing as contemporary instrument that provides cooperation of subjects of educational process" 


\title{
Барсков В.В., Забелин Б.Ф. К вопросу повышения конкурентоспособности и технологичности малорасходных газотурбогенераторов на этапе проектирования
}

\author{
Barskov V.V, Zabelin B.F. \\ The issue of increasing the competitiveness and adaptability \\ of economical gas turbo generators at the design stage
}

В статье рассматриваются проблемы при проектировании малорасходных

газотурбогенераторов, рассмотрены основные направления совершенствования установок, предложена новая тепловая схема и три возможные компоновки, описаны их преимущества и недостатки

Ключевые слова: малорасходные

газотурбогенераторы, компоновка, тепловая схема

\section{Забелин Борис Федорович}

Кандидат экономических наук, доцент Санкт-Петербургский политехнический университет Петра Великого

2. Санкт-Петербург, Полюстровский проспект, 14

Барсков Виктор Валентинович

Аспирант

Санкт-Петербургский политехнический университет Петра Великого

г. Санкт-Петербург, Полюстровский проспект, 14
The article discusses issues in the design of economical gas turbo generators, the main directions of improvement of installations proposed new thermal circuit and three possible layouts, described their advantages and disadvantages

Key words: low mass flow rate of the gas turbo generators, layout, thermal circuit

\section{Zabelin Boris Fedorovich}

Candidate of Economic Sciences, Associate Professor St. Petersburg Polytechnic University of Peter the Great

Saint-Petersburg, Polyustrovsky Avenue, 14

\section{Barskov Viktor Valentinovich \\ Graduate}

St. Petersburg Polytechnic University of Peter the Great

Saint-Petersburg, Polyustrovsky Avenue, 14

Малорасходные газотурбогенераторы (МГТГ) находят все более широкое применение в качестве автономных энергоисточников. На рынке востребованы подобные автономные энергоисточники с длительным ресурсом, низким уровнем выбросов, возможностью работать на различных видах энергоносителей и с относительно высоким КПД. При проектировании и компоновке МГТГ возникает ряд вопросов и противоречий при выборе тепловой схемы и применении основных конструкторских решений [1].

Актуальность проблемы заключается в том, что многообразие потребителей энергии и требований к виду и качеству энергообеспечения, заставляет по-новому взглянуть на роль автономных энергетических агрегатов малой 
мощности (от десятков киловатт до нескольких мегаватт) в общей структуре энергетики. В условиях современной государственной политики и курса экономики на импортозамещение, в ближайшей перспективе серьезное внимание следует уделить сооружению отечественных, относительно дешевых автономных энергетических установок (АЭУ) малой мощности, различного назначения, финансирование которых возможно как из местных бюджетов, так и за счет инвестиций частного капитала.

Одной из наиболее сложных проблем является проблема масштаба и соразмерности обстановки проточной части МГТГ. Вследствие данной особенности отдельные потери КПД будут происходить в промежутке между камерой сгорания, турбиной, компрессором и регенеративным воздухоподогревателем. Такие потери возникают в результате:

- Изгибов и поворотов в патрубках;

- Ответвлений, переходов и развилок в патрубках;

- Фланцевых соединений;

- Зазоров между элементами конструкции;

- Высокой шероховатости на внутренней поверхности патрубков;

- Установленных датчиков и зондов.

Указанные потери, при проектировании МГТГ без компенсации перечисленных факторов, могут значительно снизить КПД установки, полученный при оптимизации компрессора и турбины (Рис.1) $[1,2]$

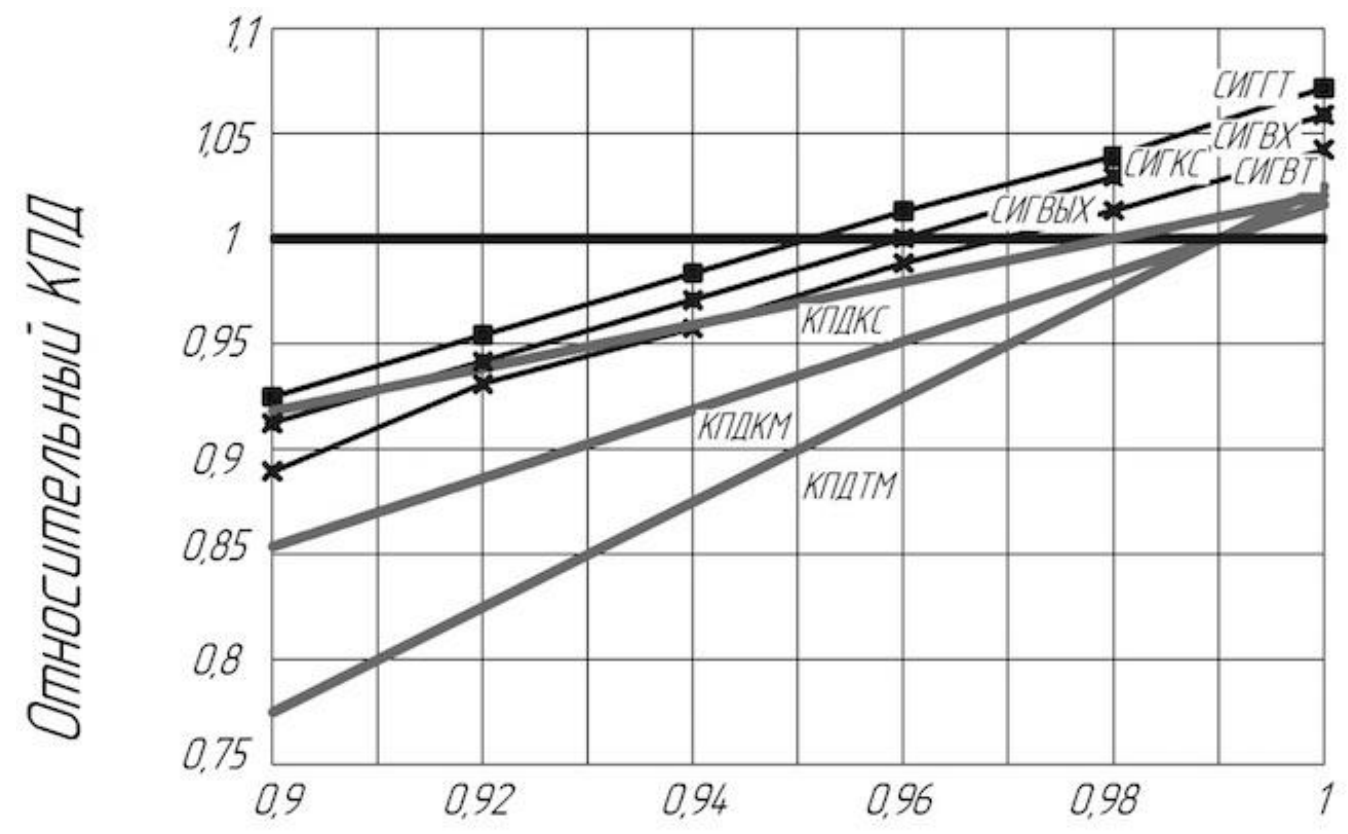

Опносительный козффициенп изменения потерь элементов ГТУ

Рис. 1. Относительный коэффициент изменения потерь элементов Гту

Известна простая тепловая схема газотурбогенератора, когда на оси одного вала находится компрессор турбина и генератор. Камера сгорания представляет отдельный блок расположенный вокруг турбины или перпендикулярно оси вала. В обоих случаях происходит поворот потока на $90^{\circ}$ или $180^{\circ}$. В 
случае применения рекуперативного воздухоподогревателя тракты воздуха и газа еще более осложняются, что существенно снижает КПД установки [1].

Тепловая схема газотурбогенератора со свободной турбиной позволяет оптимально подобрать обороты компрессора и обороты свободной турбины. По воздушному и газовому тракту с учетом газоходов имеются те же проблемы. Преимуществом двухвального ГТГ является облегченный пуск, который требует меньших затрат энергии, т.к. силовая турбина в нем не участвует $(n=0)$. Для пуска в обоих случаях требуется специальное устройство $[1,2]$.

В простых схемах оптимизация происходит по пути определения оптимальной частоты вращения компрессора, удовлетворяющей также и оптимальным параметрам турбины. Поскольку КПД компрессора меньше, то выбор частоты вращения ротора компрессора является определяющим при выборе рабочей частоты. С потерей в КПД турбины приходится мириться.

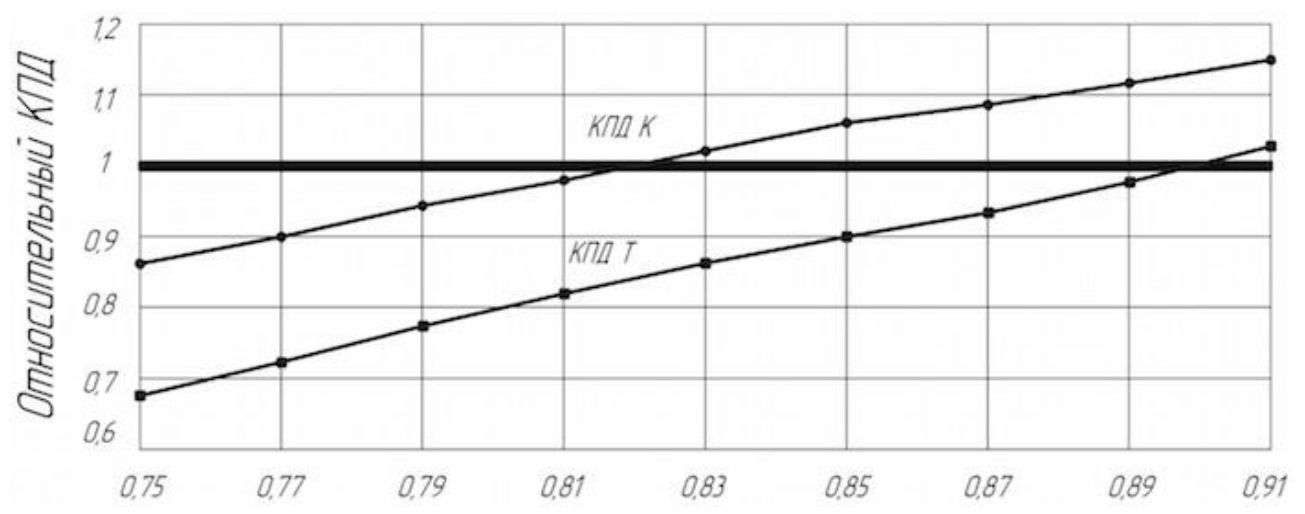

Pис. 2. Относительный коэффициент изменения КпД турбины и компрессора

Из Рис. 2 видно, что КПД турбины все равно, выше КПД компрессора, хотя рабочее число оборотов турбины находится не в оптимальной точке. Оптимальный относительный КПД установки обеспечивается при меньшем относительном КПД турбины.

Для решения указанной проблемы предлагается тепловая схема газотурбогенератора, где компрессор приводится во вращение от электродвигателя (Рис.3).

В случае развязанных механически валов турбины с генератором и компрессора с электродвигателем возможно:

- Выбрать оптимальное значение оборотов компрессора, причем, определяющим будет максимально допустимые обороты по прочности колеса;

- Сделать осевой вход в компрессор (наименьшие потери со стороны входного патрубка, нет поворота потока, как в случае с улиткой) такая возможность имеется при исполнении двухопорного ротора генератора с консольным вылетом рабочего колеса компрессора;

- Выбрать оптимальное значение оборотов турбины, причем определяющим будет максимально допустимая температура, перед рабочим колесом турбины исходя из жаропрочности и жаростойкости материала колеса. В большей степени, КПД турбины определяет температура на входе (Т3);

- Выбрать оптимальную компоновку МГТГ. [3] 


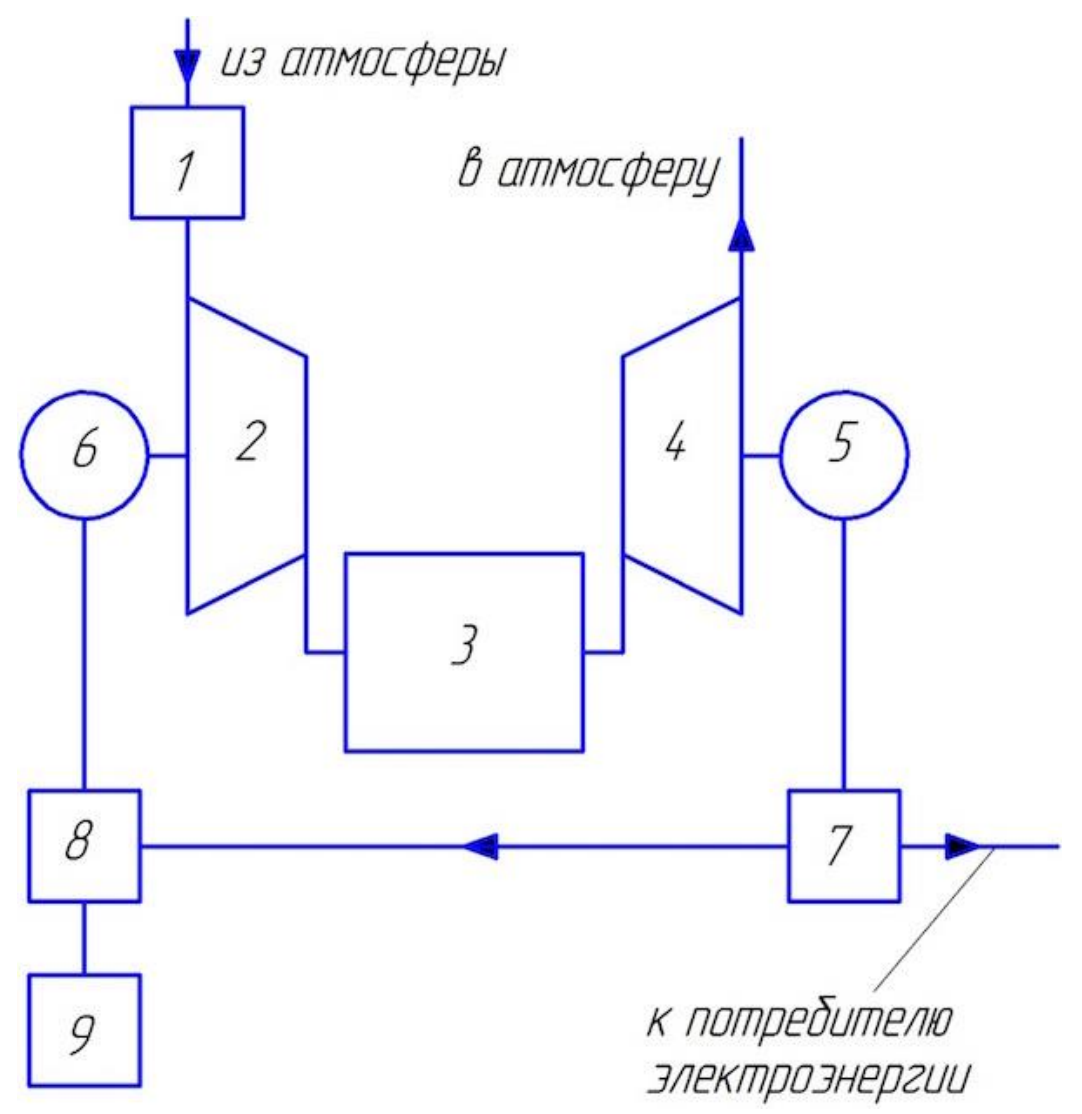

Рис. 3. Предлагаемая тепловая схема газотурбогенератора

1 -комплексное воздухоочистительное устройство; 2-компрессор;

3-камера сгорания; 4-турбина; 5-генератор; 6- электродвигатель;

7-блок силовой электроники генератора; 8-блок силовой электроники электродвигателя - пусковое устройство; 9-аккумуляторы

Электродвигатель при пуске получает энергию от внешнего источника питания, а в процессе работы от генератора, приводимого турбиной. Излишек энергии генератор отдает потребителю.

Существенным недостатком предложенной схемы будет необходимость применения одновременно двух электрических машин, что негативно повлияет на:

- КПД установки, т.к. максимальный суммарный КПД двух электрических машин не будет превышать 0,98 ;

- Полезную мощность, т.к. электрические машины ограничены по габаритным размерам;

- Надежность, т.к. для управления требуется сложная система автоматики и регулирования;

- Стоимость, т.к. для изготовления электрических машин с достаточным КПД требуются значительные материальные и трудовые затраты.

Однако указанные недостатки не перекрывают достоинств предложенной схемы, на ее основе разработаны три компоновки МГТГ.

На Рис. 4 показаны предлагаемые 3D модели компоновок МГTГ. 


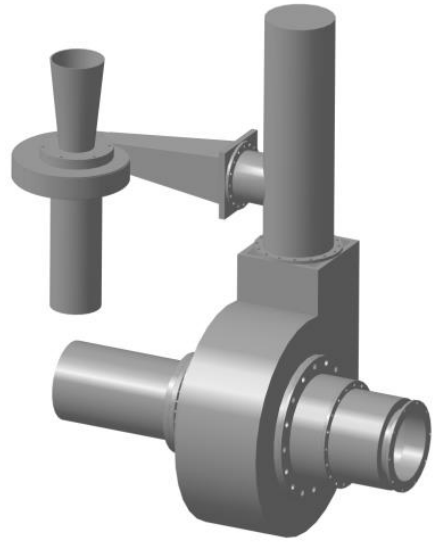

a)

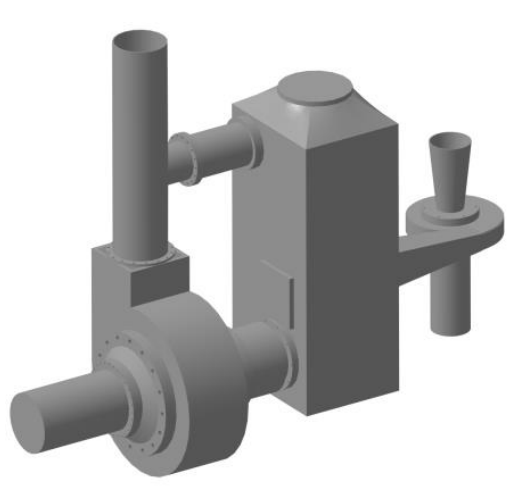

б)

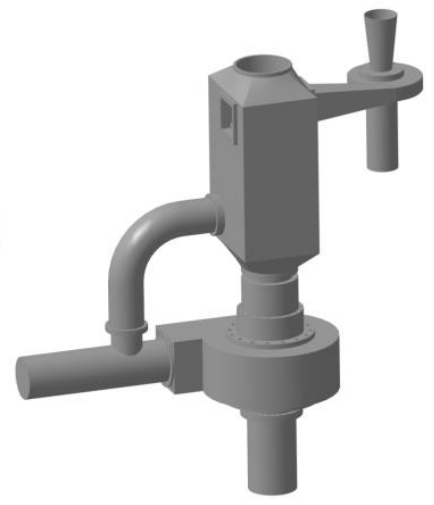

в)

Puc. 4 a) 3D модель МГTГ простой тепловой схемы без рекуперативного воздухоподогревателя; б) 3D модель компоновки МГTГ с прямоточным рекуперативным воздухоподогревателем; в) 3D модель MГTГ с противоточным рекуперативным воздухоподогревателем

Основные факторы которые необходимо учесть при проектировании:

- Необходимо минимизировать количество переходных патрубков;

- Переходные патрубки необходимо минимизировать по длине;

- Переходные патрубки необходимо минимизировать по количеству поворотов [4].

Критерием создания компоновки (Рис. 4а) послужило то, что в газовоздушном тракте имеется всего один поворот потока в тупиковой камере сгорания. Воздух из компрессора поступает в тупиковую камеру сгорания. Из камеры сгорания газ поступает в улитку перед сопловым аппаратом. Но КПД установки будет слишком низким (менее 15\%) из-за отсутствия рекуперативного воздухоподогревателя.

Подобная компоновка возможна в случае:

- Применения установки в качестве резервной или аварийной с кратковременным режимом работы, т.к. КПД не будет иметь весомого значения;

- Применения установки в условиях наличия доступного стороннего источника тепла для подогрева воздуха, например отходящие газы от более мощных газотурбинных установок. (При этом возможно разнесение турбины и компрессора на значительно расстояние).

- Применения установки в составе другой, более мощной установки в качестве вспомогательного агрегата.

Критерием создания компоновки (Рис. 4б) послужило то, что с учетом рекуперативного воздухоподогревателя в газо-воздушном тракте имеется 4 поворота потока, причем рекуперативный воздухоподогреватель прямоточный. Как и в предыдущей компоновке применена камера сгорания тупикового типа. Но из-за низкой степени регенерации данная схема не перспективна, т.к. КПД установки будет относительно низким (менее 25\%).

Подобная компоновка возможна в тех же случаях, что и предыдущая.

Критерием создания компоновки (Рис. 4в) послужило то, что в газовоздушном тракте имеется 3 поворота потока, причем 2 из них в противоточном 
рекуперативном воздухоподогревателе. Как и в предыдущей схеме применена камера сгорания тупикового типа. Данная схема наиболее перспективна т.к.:

- КПД установки будет относительно высоким (34-35\%);

- Возможно применение установки в качестве основной энергоустановки с длительным режимом работы;

С конструкторской стороны сборка предложенных вариантов более простая, чем классическая схема, т.к. собираемых частей меньше:

- В случае замены единичной детали в компрессоре или турбины, надо будет разобрать только ту сборку, где надо заменить единичную деталь;

- Балансировка любого из двух коротких двухопорных роторов намного проще, чем одного длинного трехопорного ротора.

Применение компрессора с отдельным электроприводом позволит:

- Повысить КПД компрессора, за счет увеличения $\pi$ к в пределе для простой тепловой схемы, то можно получить общее КПД ГТГ $34 \%-35 \%$;

- Уменьшить габариты и, как следствие, массу компрессорной части;

- Уменьшить потери в газо-воздушном тракте за счет оптимальной компоновки. Следует также отметить упрощение тепловых компенсаций от расширения узлов от температуры;

- Применение двух коротких роторов вместо одного длинного позволит еще более снизить уровень вибрации, что, повысит надежность изделия;

- Применение двух коротких роторов уменьшает радиальную нагрузку на подшипники, т.к. вес любого из коротких роторов меньше одного длинного, что повысит надежность подшипников и при сохранении степени нагрузки позволит уменьшить осевые размеры роторов;

- Сборка отдельно двух турбомашин значительно проще сборки одновального ГТГ;

- Собственная сборка общей схемы осуществляется по двум фланцам для компрессора (вход и выход), присоединение проводов питания и по двум фланцам для турбины (вход от камеры сгорания и выход) и присоединение проводов питания;

- Сборка одновального ГТГ состоит из сборки отдельных частей ротора (генераторная часть, компрессорная часть и турбинная) с соответствующими статорными частями.

В конструкции двухвальной МГТГ мощность генератора возрастает и становится равной мощности турбины за вычетом потерь. Соответственно возрастают и размеры генератора. В случае использования уже разработанного и освоенного в производстве генератора, мощность турбины уменьшается и, соответственно, ее размеры становятся меньше. Уменьшение мощности турбины ведет к уменьшению расхода воздуха, т.е. мощность потребляемая компрессором уменьшается, и в качестве электродвигателя, используя свойство обратимости электромашин, можно применить укороченный генератор от турбины. Мощность этой электрической машины пропорциональна длине рабочей части. Одновременное увеличение оборотов компрессора еще больше уменьшит потребляемую мощность и, следовательно, габариты МГТГ. 


\section{Список литературы:}

1. Кириллов И.И. Теория турбомашин. Л., Машиностроение, 1972. 533 с.

2. Галеркин Ю.Б., Козаченко Л.И. Турбокомпрессоры. Санкт-Петербургский государственный политехнический университет. СПб., 2008.

3. Рассохин В.А., Забелин Н.А., Матвеев Ю.В. Основные направления развития микротурбинных технологий в России и за рубежом // Научно-технические ведомости СПбГПУ. СПб., 2011. № 4 (135). C. 41-51.

4. Беседин С.Н. и др. Разработка и создание автономных энергетических установок малой мощности на базе газотурбинного цикла простой схемы с сильно-развитой системой регенерации тепла // Инновационная политика и изобретатели (Россия - начало ХХІ века). Санкт-Петербургский государственный политехнический университет.

(C) 2015, Барсков В.В., Забелин Б.Ф.

К вопросу повышения конкурентоспособности и технологичности малорасходных газотурбогенераторов на этапе проектирования
(C) 2015, Barskov V.V, Zabelin B.F.

The issue of increasing the competitiveness and adaptability of economical gas turbo generators at the design stage 


\title{
Вицентий А.В., Шишаев М.Г. К вопросу о разработке когнитивных интерфейсов для систем информационной поддержки управления развитием пространственно-распределенных систем
}

\author{
Vicentiy A.V., Shishaev M.G. \\ To the question of the cognitive interfaces development \\ for information management support systems of the \\ spatially distributed systems development
}

В работе рассматривается понятие когнитивного интерфейса пользователя в системах информационной поддержки управления развитием пространственно-распределенных объектов и систем. Показывается необходимость учета перцептивных возможностей пользователя при разработке эффективных интерфейсов Ключевые слова: когнитивный интерфейс, пространственно-распределенные системы, восприятие информации

\section{Вицентий Александр Владимирович}

Кандидат технических наук, доцент, научный сотрудник

Институт информатики и математического моделирования технологических процессов Кольского НЦ РАН

Кольский филиал ПетрГУ

Мурманская обл., г. Апатиты, ул. Ферсмана, 24 A

\section{Шишаев Максим Геннадьевич}

Доктор технических наук, доцент

Институт информатики и математического моделирования технологических процессов Кольского НЦ РАН

Кольский филиал ПетрГу

Мурманская обл., г. Апатиты, ул. Ферсмана, 24 A
This paper considers the concept of cognitive user interface in systems of information management support for spatially distributed objects and systems development management. The necessity of taking into account perceptual capabilities in effective user interfaces developing are shown

Key words: cognitive interface, spatially distributed systems, perception of information

Vicentiy Alexander Vladimirovich

Candidate of Engineering Sciences, Associate Professor, Researcher

Institute for Informatics and Mathematical Modelling of Technological Processes of the Kola Scientific Center, Russian Academy of Sciences The Kola branch of Petrozavodsk State University Murmansk region, Apatity Fersman st., 24 A

\section{Shishaev Maxim Gennadievich Doctor of Engineering Sciences, Associate Professor Institute for Informatics and Mathematical Modelling of Technological Processes of the Kola Scientific Center, Russian Academy of Sciences The Kola branch of Petrozavodsk State University Murmansk region, Apatity Fersman st., 24 A}

При решении задач по созданию прикладных интеллектуальных информационных технологий поддержки управления развитием крупными пространственно-организованными биосоциоэкономическими системами помимо традиционных вопросов связанных с получением и обработкой информации встают и вопросы, связанные с обеспечением наиболее эффективного способа 
представления информации пользователю таких технологий - лицу, принимающему решения (ЛПР).

К сожалению, анализ современных разработок в этой области показывает, что вопросам создания методов и технологий визуального отображения информации таким образом, чтобы она воспринималась конечным потребителем максимально эффективно, уделяется крайне мало внимания. Складывается практика, при которой на всех этапах создания информационных систем (ИС) основное внимание уделяется их функциональной насыщенности, а проектирование и реализация интерфейсов осуществляются по «остаточному принципу». Такой подход к разработке приводит к негативным последствиям, связанным с тем, что конечный пользователь информационной системы либо вовсе не пользуется заложенными в ИС функциями, либо использует их лишь частично - настолько, насколько это кажется ему удобным. Иначе говоря, пользователь использует функции системы через предоставленные ему разработчиками средства интерфейса настолько, насколько они соответствуют его представлениям об удобстве и логичности их организации. Плохо организованный интерфейс выступает препятствием на пути полноценного использования всего функционала информационной системы [1].

Эта проблема еще больше обостряется, если речь идет о мультипредметных информационных системах, ориентированных на различные категории пользователей, в отличие от специализированных или проблемноориентированных ИС, нацеленных на решение некоторого ограниченного спектра взаимосвязанных прикладных задач или же информационную поддержку некоторого единственного сообщества пользователей, определяемого, например, профессиональными интересами. Мультипредметные системы выдвигают специфические требования к качеству их пользовательского интерфейса [2]. Они должны обеспечить удобный интуитивно понятный механизм доступа и интерпретации информации для пользователей разных категорий. Реализацию такого механизма можно осуществить в рамках когнитивного интерфейса - интерфейса, обладающего совокупностью свойств, обеспечивающих его интуитивную понятность и способствующих эффективному пониманию передаваемой информации.

Решение задачи обеспечения разных категорий пользователей удобными, гибкими и эффективными инструментами получения информации средствами единого для всех пользователей системы статичного графического интерфейса не представляется возможным. Решением может быть разработка принципов синтеза динамических интерфейсов, учитывающих перцептивные особенности пользователей и их ментальные модели (представления об окружающем мире), взаимодействующих с системой в данный момент. При этом степень когнитивности интерфейса определяется тем, насколько он соответствует ментальным стереотипам пользователя.

При решении задач управления развитием крупных (масштаба региона) пространственно-распределенных систем используются сложные интегрированные систем поддержки принятия решений (СППР). Практически повсеместно в основе таких современных СППР лежат геоинформационные системы 
(ГИС). С учетом того, что современные ГИС для решения таких задач содержат в своих базах данных огромные объемы информации по различным предметным областям и используют базы знаний в качестве хранилища формализованных знаний, их с полным правом можно называть мультипредметными интеллектуализированными информационными системами или интеллектуальным ГИС (ИГИС).

Ввиду сложности решаемых задач, обусловленной увеличением объемов обрабатываемой информации, необходимостью оперирования в процессе управления пространственно-распределенными системами множеством разнородных и неустойчивых факторов ИГИС должны обеспечивать оперативное формирование картографических изображений с учетом актуального состояния характеристик территории. При этом картографическое изображение должно быстро и правильно читаться пользователем, иными словами визуальные образы сформированного ИГИС геоизображения должны быть верно интерпретированы ЛПР. Для решения этой задачи предлагается технология динамической когнитивной геовизуализации, основанная на использовании формализованных в виде онтологий знаний о предметной области и особенностях визуального восприятия информации (ментально-перцептивных стереотипах) человеком $[3,4]$. Ключевым компонентом технологии является специализированная онтология пользовательского представления, описывающая визуальные картографические стереотипы для различных категорий пользователей.

Open Geospatial Consortium в спецификации SLD описывает стандарт представления пространственной информации, которая может быть представлена с помощью 4 видов объектов (точка, линия, полигон, растр), а также и возможные варианты их визуализации через описание на языке xml. B coвременных ИГИС правила геовизуализации создаются специалистами заранее под каждую задачу. В технологии динамической когнитивной геовизуализации за атрибутирование геоизображения отвечает расширение для GeoServer, которое генерирует файлы стилей $\mathrm{xml}$ на основе логического вывода на онтологиях предметной области и пользовательского представления, с учетом характеристики задачи и контекста ситуации.

В процессе интерпретации ситуации, отображаемой геоизображением, нужно оценивать объекты как единое целое в их взаимосвязи. Процесс геовизуализации в ИГИС состоит из следующих этапов:

- на основе формулировки задачи, пространственной и атрибутивной информации, хранящейся в ИГИС, а также информации из разнородных внешних источников в рамках расчетно-аналитической подсистемы формируются набор картографических слоев, подлежащие визуализации;

- в ходе логического вывода на онтологиях предметной области и пользовательского представления, с учетом характеристики задачи и контекста ситуации, осуществляется генерализация пространственных данных;

- на основе полученных данных осуществляется визуальное атрибутирование геоизображения (сопоставление пространственным объектам графических образов - форм и визуальных атрибутов). 
Таким образом, обеспечивается содержательное соответствие картографического геоизображения специфике решаемой задачи и психологии восприятия информации ЛПР. Использование в рамках технологии формализованных знаний о ментальных стереотипах пользователей в форме онтологии пользовательского представления позволяет оперативно формировать картографические интерфейсы информационных систем, обладающие высоким уровнем когнитивности. В свою очередь, формализованные в виде онтологии знания о предметной области обеспечивают возможность автоматизированного анализа информации, характеризующей ситуацию, поступающей из различных источников. Такие особенности данной технологии предоставляют широкие возможности для построения на ее основе когнитивных интерфейсов средств информационной поддержки управления развитием пространственнораспределенных систем

\section{Список литературы:}

1. Шишаев М.Г., Порядин Т.А. Проблема формирования эффективных картографических интерфейсов информационных систем для задач управления территориями // Труды Кольского научного центра РАН. Информационные технологии. 2013. Вып. 4. С. 69-76

2. Шишаев М.Г., Диковицкий В.В., Ломов П.А. Формализация задачи построения когнитивных пользовательских интерфейсов мультипредметных информационных ресурсов // Вестник Кольского Научного Центра 3/2011. С. 62-72.

3. Ломов П.А., Шишаев М.Г., Диковицкий В.В. Преобразование OWL-онтологии для визуализации и использования в качестве основы пользовательского интерфейса // Онтология проектирования. Самара: Новая техника. 2012. №3. С. 49-61.

4. Koffka K. Principles of Gestalt psychology. N.Y.: Routledge. 1935. 720 c.

\section{References:}

1. Shishaev M.G., Poryadin T.A. The problem of information systems effective mapping interfaces formation for management tasks territories // Proceedings of the Kola Scientific Center, Russian Academy of Sciences. Information technology. 2013 Vol. 4. Pp. 69-76.

2. Shishaev M.G., Dikovitskiy V.V., Lomov P.A. The formalization of the constructing cognitive user interfaces problem for multisubject information resources // Bulletin of the Kola Science Center. 3/2011. Pp. 62-72.

3. Lomov P.A., Shishaev M.G., Dikovitskiy V.V. Convert OWL-ontology for visualization and use as the basis of the user interface // Ontology design. Samara: A new technique. 2012. №3. Pp.49-61.

4. Koffka K. Principles of Gestalt psychology. N.Y.: Routledge, 1935. 720 p.

(C) 2015, Вицентий А.В., Шишаев М.Г.

К вопросу о разработке когнитивных интерфейсов для систем информационной поддержки управления развитием пространственнораспределенных систем
(C) 2015, Vicentiy A.V., Shishaev M.G.

To the question of the cognitive interfaces development for information management support systems of the spatially distributed systems development 


\title{
Дикарева Е.А., Сдобнова Л.Д., Сергеева А.А. Техническое оснащение города для развития велодвижения в г. Волгограде
}

\author{
Dikareva E.A., Sdobnova L.D., Sergeeva A.A. \\ City hardware for development of the cycle movement in Volgograd
}

В данной статье рассматривается проблема формирования благоприятной среды для развития велодвижения в г. Волгограде. Разбираются необходимые для решения вопросы на конкретных примерах организации велосипедного движения в Голландии. Представлены различные образцы решения регулирования велодвижения, разделения велодорожек от автодорог и другие

сопутствующие элементы. Также было обращено внимание и на образование различных

мероприятий для велосипедистов в г. Волгограде Ключевые слова: велосипедная инфраструктура, велопарковка, велосипедные мероприятия,

велополосы

\section{Дикарева Екатерина Александровна}

Студент

Волгоградский Архитектурно-Строительный Университет

г. Волгоград, ул. Академическая, 1

\section{Сдобнова Лилия Дмитриевна}

Студент

Волгоградский Архитектурно-Строительный Университет

г. Волгоград, ул. Академическая, 1

Сергеева Анастасия Александровна

Студент

Волгоградский Архитектурно-Строительный Университет

2. Волгоград, ул. Академическая, 1
In this article the problem of formation of the favorable environment for development of the cycle movement in Volgograd is considered. Questions, necessary for the decision, on concrete examples of the organization of the bicycle movement understand Holland. Various samples of the solution of regulation of the cycle movement, division of cycle paths from highways and other accompanying elements are presented. Also the attention and to formation of various actions for cyclists in Volgograd was paid

Key words: bicycle infrastructure, cycle parking, bicycle actions, cycle strips

\section{Dikareva Ekaterina Alexandrovna \\ Student \\ Volgograd architectur and building university \\ Volgograd, Akademicheskaya, 1}

\author{
Sdobnova Lilya Dmitrievna \\ Student \\ Volgograd architectur and building university \\ Volgograd, Akademicheskaya, 1
}

\author{
Sergeeva Anastasia Alexandrovna \\ Student \\ Volgograd architectur and building university \\ Volgograd, Akademicheskaya, 1
}

Сегодня во всем мире набирает популярность экологически чистый транспорт, который позволяет не только перемещаться без пробок, но и дает необходимую физическую нагрузку, что крайне важно, учитывая современный образ жизни человека. Несомненно, таким транспортом является велосипед. В Волгограде велодвижение только начинает развиваться, поэтому важно учесть 
все аспекты для формирования благоприятной среды для велосипедистов. Для этого была проведена исследовательская работа.

Предмет исследования

Предметом исследования является велодвижения в современной инфраструктуре города Волгограда. Его текущее состояние, варианты развития, проводимые мероприятия по его улучшению и по популяризации велодвижения среди горожан.

Методы исследования

- Анализ текущего состояния велосипедной инфраструктуры в г. Волгограде;

- Исследование и анализ примеров организации велодвижения в Голландии;

- Приведение примеров уже существующих мероприятий в данной области в г. Волгограде

- Подведение итогов исследования в качестве предлагаемых вариантов для развития велосипедного движения в г. Волгограде.

Велоинфраструктура сегодня: проводимые мероприятия и проблемы «С каждым днем становится все больше велосипедистов, пропагандирующих своим примером здоровый образ жизни. Кроме того, в условиях большого города это прекрасная возможность воспользоваться экологически чистым транспортом, минуя при этом автомобильные пробки. Депутатский корпус проводит большую работу по поддержке велодвижения в Волгограде. Рабочая группа, в которую входят и волгоградские велосипедисты, занимается вопросами развития велосипедной инфраструктуры в городе» отметил депутат городской Думы Алексей Волоцков. Не однократно проводились велопробеги, например, один из последних проводился 19 мая 2014 года велопробег, участие в котором приняли более 500 спортсменов и любителей. Основная цель мероприятия - популяризация велоспорта среди жителей города. К сожалению, на сегодняшний день в городе полностью отсутствуют велодорожки, практически нет парковых зон пригодных для велопрогулок, а велопарковки только начинают появляться.

В городе компанией «Билайн» инициированы проекты с целью развития в городе инфраструктуры для велосипедистов, пропаганды здорового образа жизни среди жителей города и области, а также в целом для улучшения экологической обстановки. Велопарковки «Билайн» представляют собой увеличенную копию велосипеда «Пенни-фартинг», но вместо заднего колеса у конструкций имеются рейки для крепления велосипедов. Летом 2014 года компания «Билайн» установила парковки для велосипедов на территории образовательных учреждений города. Так же была установлена велопарковка с возможностью мелкого ремонта велотранспорта. В отличие от стандартной парковки, велосервис позволяет в случае необходимости произвести экспрессремонт велосипеда: подкачать шины, снять и привести в порядок колеса и т.д. Расположена конструкция на Центральной Набережной недалеко от Волгоградского Музыкального театра. 
Активистами велодвижения был создан проект «Велоэкскурсии в Волгограде». Не так давно в Волгограде стартовал интересный проект - исторические велоэкскурсии. Его цель - изучение неизвестной истории родного города, передвигаясь при этом на велосипедах. Поучаствовать в необычных экскурсиях зовут всех, главное условие - приехать на своем двухколесном друге.

Организаторы экскурсий - студентка и блогер Оксана Кононенко и активист по созданию велоинфраструктуры в Волгограде Андрей Куртучкин. Чуть позже к команде подключились краеведы-любители Денис Высоцкий и Денис Разумов, они же и стали основными гидам - проводниками по достопримечательностям.

В Волгограде запустили краудфандинговый проект по установке велопарковок. Волгоградский велоактивист Вячеслав Шитиков инициировал в нашем городе проект по установке велопарковок, привлекая при этом непосредственно велосипедистов и горожан. Суть проекта заключается в том, что выбор места установки велопарковки и ее финансирование производятся за счет людей, неравнодушных к вопросу создания безопасной и удобной велоинфраструктуры в Волгограде. Этот способ в миру известен более как краудфандинг - коллективное сотрудничество людей, которые добровольно объединяют свои деньги или другие ресурсы вместе.

Организация велосипедного движения в Голландии

Для того, чтобы лучше понять все аспекты, необходимые для создания развитой системы велоинфраструктуры, исследуем пример организации велодвижения, таковым примером является Голландия. Это страна является первой в мире по числу велосипедистов. Во многих городах велосипедов, намного больше чем жителей. В Гааге и Амстердаме около $70 \%$ поездок осуществляются на велосипедах. В Голландии велосипед является частью повседневной жизни, а не символом образа жизни людей, ведущих определенный образ жизни. Итак, рассмотрим организацию велодвижения в Голландии.

Велодвижение в стране поддерживается и поощряется на всех уровнях, к тому же создана самая безопасная и совершенная сеть велосипедных дорог в мире. Практически все автомагистрали Нидерландов дублированы велодорожками.

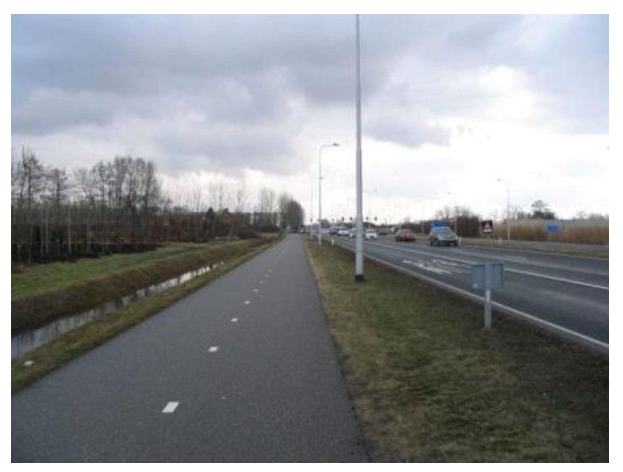

Пересечения с авто и вело дороги или регулируются светофором. 


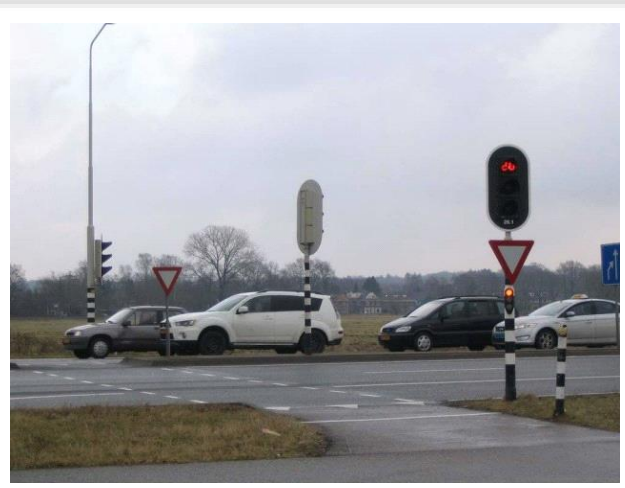

Или, при слишком большом желании городка - подземным переездом.

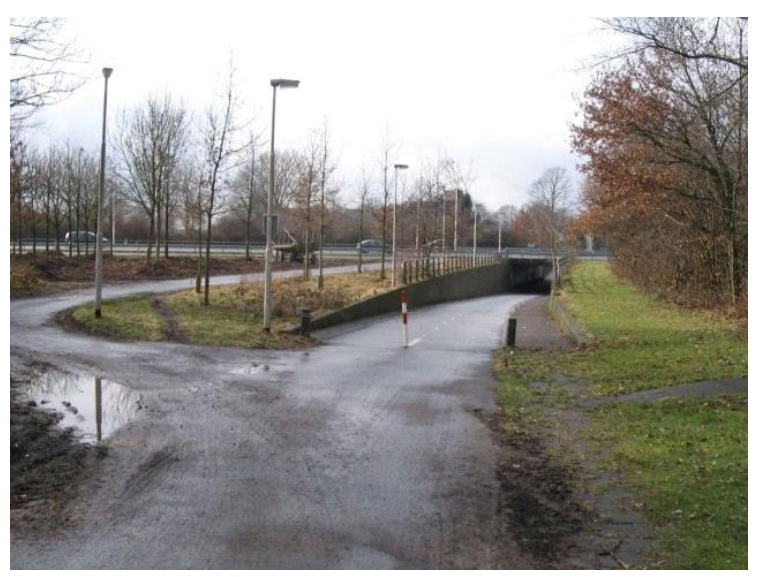

Светофоры делятся на 4 вида: 1- без кнопки вызова, 2 - с кнопкой, 3 - с кнопкой и датчиком движения, имитирующим вызов при подъезде к переезду и к функциям третьего добавлена четвертая функция автоматического включения велосипедисту зеленого света если а) дорожная ситуация позволяет б) если скорость велосипедиста перед светофором меньше 7-8км/ч.) Это, с одной стороны, позволяет велосипедисту не останавливать велосипед, а с другой заставляет его снизить скорость и внимательно проехать перекресток.

Отдельные велодороги пронумерованы, на их перекрестках стоят такие стенды.

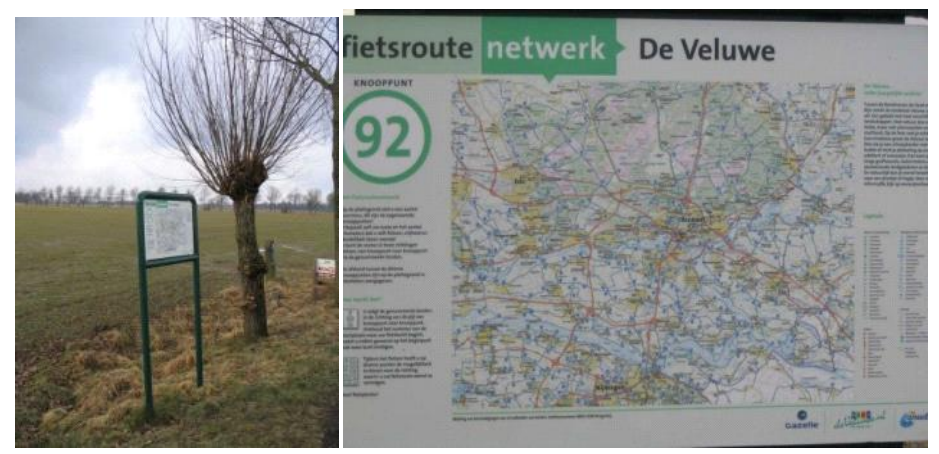

На них указан номер текущего чекпунта и показано куда и как от него можно доехать. Синяя сетка - это сетка велодорожек. 
В городах почти все улицы даже с небольшим по активности движением оборудованы велодорожками. Для того, чтобы пешеходы не ходили по велодорожкам - рядом с большинством велодорожек проложены и пешеходные.

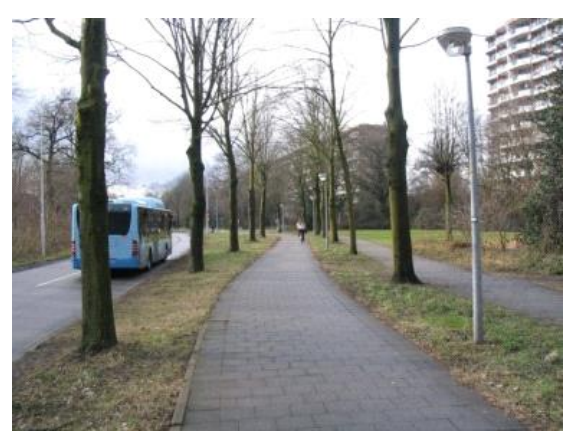

А если улица слишком уж маловажная - то на ней просто отчерчивают велодорожку.

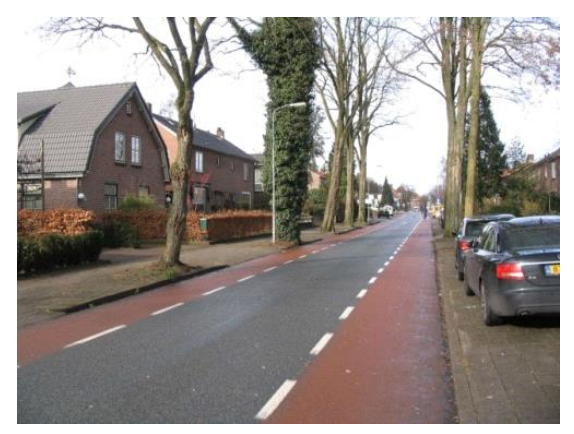

Большая часть перекрестков - круговые развязки, на которых приоритет имеют велосипедисты.

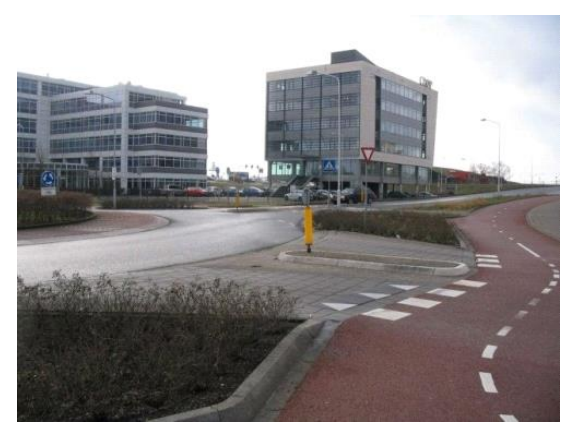

К тому же все свои маневры велосипедисты сопровождают жестами, даже на пустых улицах. В школах уже с первого класса детей обучают правилам дорожного движения и сами родители приобщают детей в велоезде уже с детского возраста, но перемещаться без сопровождения в Нидерландах нельзя до 18 лет.

Часть улиц только пешеходно-велосипедная. 


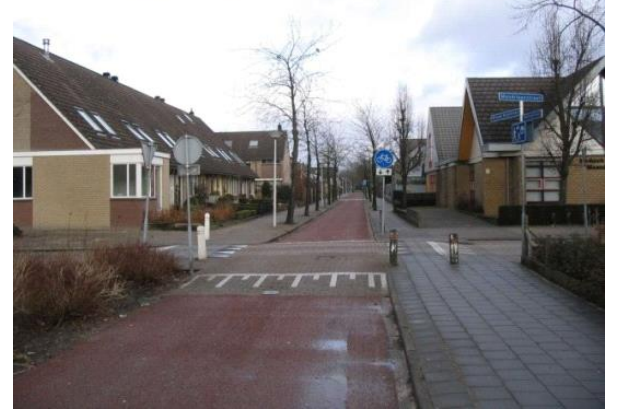

Парковок - большое количество у всех зданий и сооружений. Существуют подземные велосипедные парковки, естественно огромное количество парковочных мест в жилых кварталах, есть даже перехватывающие парковки для тех, кому надо делать пересадку с велосипеда на автобус.

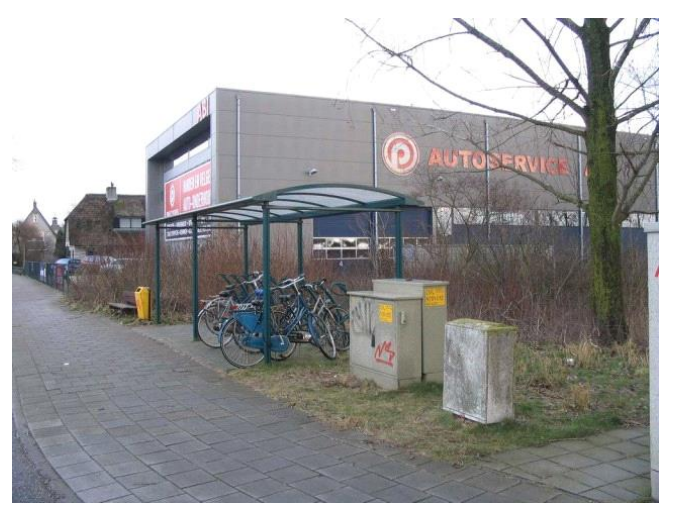

Велодорожки в Нидерландах имеют гладкое покрытие, выделены цветом и обозначены специальными знаками и светофорами. К тому же велосипедисты имеют преимущество на дороге, существует специальное законодательство регулирующее движение велосипедистов и их обозначение специальными светоотражающими знаками и т.д. В целом в стране делается все для развития велоинфраструктуры.

Предлагаемые на основе исследования варианты для дальнейшего благоприятного развития велоинфраструктуры в г. Волгограде.

Сейчас несомненно тема организации велодвижения актуальна. В адрес городских властей поступают обращения с просьбой о выделении для велосипедистов специальных дорожек.

Нужна четко разработанная транспортная схема, которая могла бы правильно организовать движение в город, перераспределить автомобильный транспорт и организовать велодвижение. Для этого необходимо:

- Создание комфортных велодорожек. Это должна быть часть дороги, физически отделённая бордюром или несколько приподнятая над проезжей частью. Это позволит чувствовать себя в безопасности при езде на велосипеде - Необходимо создание велопарковок. (Для примера, в Нью-Йорке есть закон об офисных зданиях, предусматривающий обязательную установку охраняемых велопарковок). 
- Создание пунктов велопроката.

- Создание доброжелательной велоинфраструктуры в городе: «зеленая волна» для велосипедистов, приподнятые велоурны, велопарковки возле подземных станций трамваев, льготы либо техническая возможность перевозки велосипеда на трамвае, автобусе или скоростного трамвая.

Город может получать доходы от организации велодвижения. Достаточно, например, в городских кафе и ресторанах предусмотреть скидку для всех приезжающих на велосипеде и сообщить о подобных акциях.

Любые мероприятия на велотему очень важны в развитии городского велодвижения.

Предлагаемые мероприятия:

- Велопарады и велопробеги

- Рекламные щиты с призывом использовать велосипед в качестве ежедневных поездок на работу

- Создание велосервисов с возможностью подкачать шины, осуществить мелкий ремонт велосипеда

- Популяризация езды на велосипеде среди женщин

- Создание возможности круглогодично ездить на велосипеде, т.е. вовремя чистить снег с дорожек и посыпать дорожное покрытие не реагентом, а, например, гранитной крошкой, чтобы не было скользко.

Велодорожка должна создаваться за счет проезжей части, чтобы люди могли добраться на велосипеде куда угодно.

Применение инноваций в строительстве велодорожек. В Нидерландах, например, недавно построили велодорожку из солнечных батарей. Энергия с велодорожки используется для обеспечения светофоров, уличных фонарей и ближайших домов.

Заключение

На основе проведенного исследования можно сделать вывод о том, что велоинфраструктура в г. Волгограде находится сейчас на начальном этапе, поэтому необходимо тщательным образом продумать все варианты для её дальнейшего развития. Разрабатывая проекты по улучшению велодвижения, требуется также учитывать не только интересы самих велосипедистов, но и также интересы пешеходов и автомобилистов, так как это поможет сформировать благоприятный облик города, который является удобным для проживающих в городе людей с различными интересами.

\section{Глоссарий}

Велосипедная инфраструктура - совокупность дорожных элементов, объектов и служб, необходимых для функционирования велотранспорта. Например, автоматизированная система велопроката, парковки, велодороги.

Велосипедные дороги - объект транспортной инфраструктуры, обозначенный и (или) размеченный для движения велотранспортных средств. Велосипедные и автомобильные дороги могут включать в себя велосипедные полосы. 
Велосипедная полоса движения (велополоса) - любая из продольных полос проезжей части, обозначенная разметкой и имеющая ширину, достаточную для безопасного движения велосипедов в один ряд.

Велосипедная парковка - специальный оборудованный участок территории или помещения, предназначенный для хранения велотранспортных средств, с путями для въезда и выезда.

Велокультура - система понятий и программ человеческой деятельности в рамках развития велосипедного движения.

Опыт многих европейских стран убедительно доказал, что широкое использование велосипеда как экологически чистого, экономичного, удобного и полезного для здоровья транспортного средства эффективно помогает решать экологические проблемы и помогает в решении проблем с транспортом. Однако, в нашем городе, к сожалению, велокультура находиться еще на зачаточном уровне, поэтому очень важно поддерживать развитие велодвижения.

\section{Список литературы:}

1. URL: http://www.vlg20.ru/news/445

2. URL: http://ecodelo.org/10601-lets_bike_it_proekt_po_razvi

3. URL: http://ecamir.ru/experts/Velokultura-v-Rossii-kratkoe

4. URL: http://www.volgadmin.ru/ru/MPAuthority/News/NewsAdmin

5. URL: http://www.bbc.com/news/magazine-23587916

6. URL: http://www.nederlandfietsland.nl/en

7. URL: http://tourist.kharkov.ua/xtarticle/-Mozhno-li-import.

8. URL: http://www.kp.ru/online/news/1650281/

9. URL: http://en.wikipedia.org/wiki/Cycling_in_the_Netherlands

(C) 2015, Дикарева Е.А., Сдобнова Л.Д., Сергеева А.А. Техническое оснащение города для развития велодвижения в г. Волгограде
(C) 2015, Dikareva E.A., Sdobnova L.D., Sergeeva A.A. City hardware for development of the cycle movement in Volgograd 


\title{
Капитонов С.С., Капитонова А.В. Исследование зависимости прямого напряжения светодиода от температуры
}

\author{
Kapitonov S.S., Kapitonova A.V. \\ Research of temperature dependence of forward voltage of LED
}

В статье представлены результаты исследования температурной зависимости прямого напряжения светодиода. Приведены математические формулы, описывающие температурный коэффициент напряжения, и модель светодиода, реализованная на основе данных зависимостей. Предполагается использование полученных результатов при исследовании различных режимов работы реальных светодиодных источников света

Ключевые слова: светодиод, прямое напряжение, температурный коэффициент напряжения,

температура, полупроводниковая структура

\section{Капитонов Сергей Сергеевич}

Кандидат технических наук, доцент

Мордовский государственный университет им. Н.П. Огарёва

2. Саранск, ул. Большевистская, 68

\section{Капитонова Анастасия Владимировна \\ Аспирант \\ Мордовский государственный университет им. Н.П. Огарёва \\ 2. Саранск, ул. Большевистская, 68}

The article presents the results of studies of the temperature dependence of the forward voltage of the LED. Mathematical formulas are presented, that describe the temperature coefficient of voltage, and LED model, implemented on the basis of data dependencies. It is supposed to use the results obtained in the study of various modes actual LED light sources

Key words: LED, forward voltage, temperature coefficient of voltage, temperature, semiconductor structure

\section{Kapitonov Sergey Sergeevich}

Candidate of Technical Sciences, Associate Professor Mordovia state university named N.P. Ogarev Mordovia Republic, Saransk, Bolshevistskaya st., 68

\section{Kapitonova Anastasia Vladimirovna Postgraduate}

Mordovia state university named N.P. Ogarev

Mordovia Republic, Saransk, Bolshevistskaya st., 68

В последнее время в светотехнике наблюдается тенденция перехода к твердотельным источникам света. Светодиоды имеют множество преимуществ, основными из которых являются: энергоэффективность, широкий диапазон рабочих температур, большой срок службы и простота управления [1]. Однако, в силу особенностей свойств полупроводниковых материалов, применяемых при производстве светодиодов, рабочие характеристики светодиодов зависят от величины температуры полупроводниковой структуры (ПС) [2, 3]. Таким образом, для повышения надёжности и энергоэффективности светодиодных источников света (СИС) необходимо исследовать температурные зави- 
симости параметров светодиодов и их влияние на режим работы лампы или светильника.

Наиболее важными электрическими параметрами светодиодов в состоянии высокой проводимости являются параметры его вольт-амперной характеристики, такие как пороговое напряжение UT0 и дифференциальное сопротивление rT. Данные параметры определяются величиной прямого напряжения UF на приборе при протекании через него прямого тока iF. Поскольку температура ПС оказывает существенное влияние на прямое напряжение uF, тo, соответственно, изменяются и значения основных электрических параметров. Поэтому представляет интерес исследование зависимости прямого напряжения светодиода от температуры и описание её с помощью математических формул. Предполагается использование полученной зависимости при реализации электрической модели светодиода [4, 5].

Зависимость значения прямого напряжения на светодиоде от температуры его ПС описывает температурный коэффициент напряжения (ТКН), который определяется следующим выражением:

$$
T K H=\frac{\Delta U_{F}}{\Delta T_{j}},
$$

где $\Delta \mathrm{UF}$ - изменение значения прямого напряжения; $\Delta \mathrm{Tj}$ - изменение температуры ПС.

ТКН зависит от значений параметров ПС светодиода и описывается следующей математической зависимостью [6]:

$$
\frac{\Delta U_{F}}{\Delta T_{j}}=\frac{k}{e} \cdot \ln \left(\frac{N_{D} \cdot N_{A}}{N_{C} \cdot N_{v}}\right)-\frac{\alpha T_{j} \cdot\left(T_{j}+2 \beta\right)}{e \cdot\left(T_{j}+\beta\right)^{2}}-\frac{3 k}{e},
$$

где k - постоянная Больцмана; q - элементарный электрический заряд; ND -концентрация донорной примеси; NA - концентрация акцепторной примеси; NC -эффективная плотность состояний в зоне проводимости; Nv - эффективная плотность состояний в валентной зоне; $\alpha$ и $\beta$ - параметры Варшни; Тј - температура ПС светодиода;

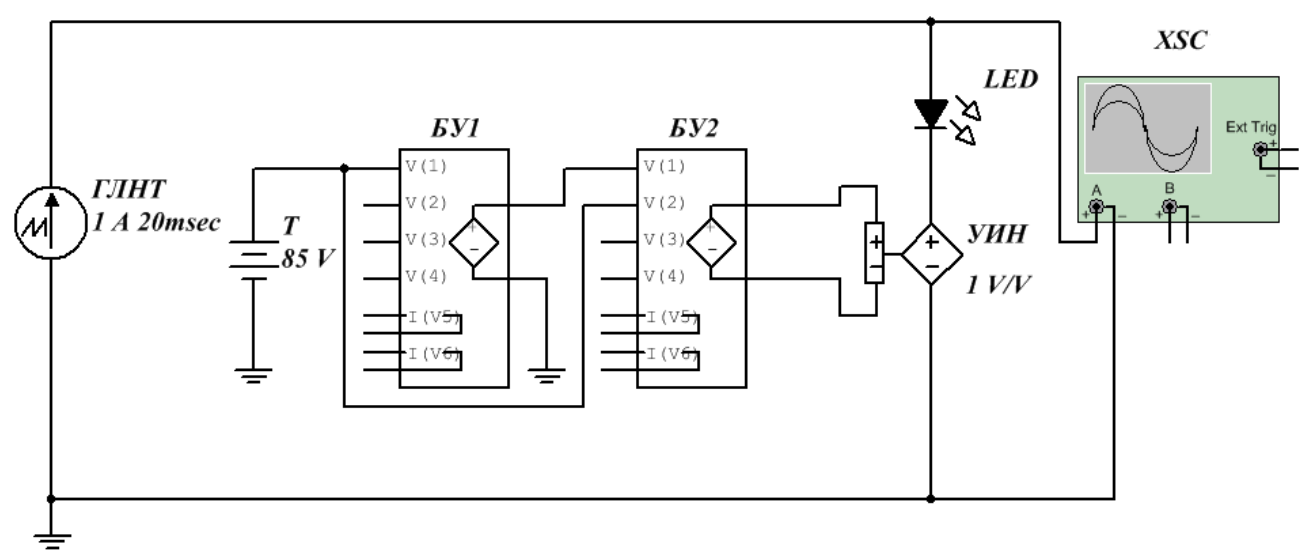

Рис. 1. Модель светодиода, описывающая зависимость величины ТКН от значений параметров его ПС 
На основе существующей электрической модели светодиода [5] и формулы (2) в среде Multisim реализована модель, описывающая зависимость величины ТКН от значений параметров ПС. Внешний вид данной модели представлен на рис. 1.

На рис. 1 введены следующие обозначения:

$\mathrm{T}$ - источник напряжения, задающий значение температуры ПС в ${ }^{\circ} \mathrm{C}$;

БУ1 - блок управления, предназначенный для расчёта значения ТКН;

БУ2 - блок управления, реализующий температурную зависимость прямого напряжения;

УИН - управляемый источник напряжения;

LED - существующая модель светодиода.

ГЛНТ - генератор линейно нарастающего тока;

XSC - осциллограф.

C помощью разработанной модели (рис. 1) проведено исследование температурной зависимости прямого напряжения светодиода, рассчитанного на максимально допустимый рабочий ток в 1 А. Через светодиод пропускался линейно нарастающий импульс тока амплитудой 1 А длительностью 20 мс. Для моделирования установлены следующие значения параметров ПС: ND = NA = $2 \cdot 1017$ см-3; NC = Nu = 2·1018 см-3; $\alpha=5,41 \cdot 10-4$ эВ/К; $\beta=204$ К. Исследование осуществлялось при следующих значениях температуры ПС:

- при комнатной температуре $\mathrm{Tj}=25^{\circ} \mathrm{C}$;

- при рабочей температуре $\mathrm{Tj}=85 \stackrel{\circ}{\circ} \mathrm{C}$;

- при максимально допустимой температуре $\mathrm{Tj}=150 \stackrel{\circ}{\circ}$.

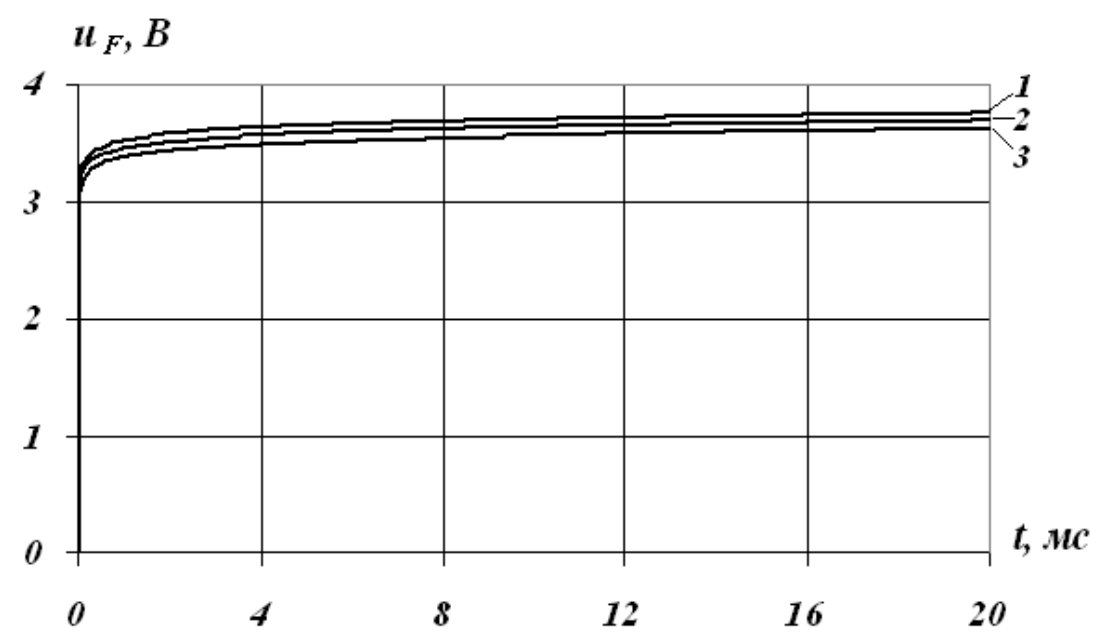

Pис. 2. Временные зависимости прямого напряжения на светодиоде при различных

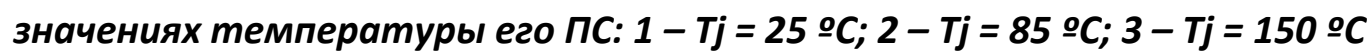

Полученные результаты моделирования температурной зависимости прямого напряжения светодиода представлены на рис. 2.

Из рис. 2 видно, что при увеличении температуры ПС светодиода прямое напряжение на нём уменьшилось на 142 мВ. При этом рассчитанный в модели ТКН равен: при $\mathrm{Tj}=25{ }^{\circ} \mathrm{C}-1,108 \mathrm{mB} /{ }^{\circ} \mathrm{C} ;$ при $\mathrm{Tj}=85{ }^{\circ} \mathrm{C}-1,126 \mathrm{mB} /{ }^{\circ} \mathrm{C} ;$ при $\mathrm{Tj}=150 \stackrel{\circ}{\circ} \mathrm{C}-1,14 \mathrm{MB} / \stackrel{\circ}{ } \mathrm{C}$. 
Таким образом, проведено исследование температурной зависимости прямого напряжения светодиода. Предполагается использование представленных математических формул и модели при исследовании различных режимов работы реальных СИС.

\section{Список литературы:}

1. Капитонов С.С., Капитонова А.В., Ашрятов А.А. Обзор современных драйверов для светодиодных ламп и светильников // Проблемы и перспективы развития отечественной светотехники, электротехники и энергетики. Саранск. 2013. С. 137-142.

2. Беспалов Н.Н., Ильин М.В., Капитонов С.С., Попов А.А. Исследование термочувствительных параметров мощных светодиодов // Проблемы и перспективы развития отечественной светотехники, электротехники и энергетики. Саранск. 2013. С. 127-130.

3. Капитонова А.В., Капитонов С.С., Ашрятов А.А. Проблемы биновки светодиодов при формировании ламп и светильников на их основе // Материалы XVIII научно-практической конференции молодых учёных, аспирантов и студентов национального исследовательского Мордовского государственного университета им. Н.П. Огарёва. Саранск. 2014. С. 221-224.

4. Капитонов С.С., Беспалов Н.Н., Капитонова А.В., Ашрятов А.А. Исследование стандартной модели светодиода в среде Multisim // Сборник научных трудов SWorld. Bыn. 4(37). T. 1. Одесса: КУПРИЕНКО СВ, 2014. C. 73-75.

5. Капитонов С.С., Беспалов Н.Н., Капитонова А.В., Ашрятов А.А., Денис Р. Кильмямятов, Диас Р. Кильмямятов Разработка электрической модели светодиода в среде Multisim // Научно-технический вестник Поволжья. 2015. Вып. № 1. С. 99-102.

6. Шуберт Ф. Светодиоды. М.: ФИЗМАТЛИТ, 2008. 496 с.

(C) 2015, Капитонов С.С., Капитонова А.В.

Исследование зависимости прямого напряжения светодиода от температуры
(C) 2015, Kapitonov S.S., Kapitonova A.V. Research of temperature dependence of forward voltage of $L E D$ 


\title{
Струлева И.А., Крутько К.Н. О взаимосвязи плотности и прочности экструзионного пенополистирола
}

\author{
Struleva I.A., Krutko K.N. \\ About interrelation of density and durability \\ of extrusive expanded polystyrene
}

Данная работа посвящена экспериментальному изучению особенностей взаимосвязи между кажущейся плотностью и прочностными характеристиками экструзионного пенополистирола

Ключевые слова: кажущаяся плотность, прочность, экструзионный пенополистирол

\section{Струлева Ирина Александровна}

Магистрант

Тамбовский государственный технический университет

г. Тамбов ул. Советская, 106

\section{Крутько Константин Николаевич \\ Магистрант \\ Тамбовский государственный технический университет \\ 2. Тамбов ул. Советская, 106}

\begin{abstract}
This work is devoted to experimental studying of features of interrelation between the seeming density and strength characteristics of extrusive expanded polystyrene
\end{abstract}

Key words: seeming density, durability, extrusive expanded polystyrene

\section{Struleva Irina Aleksandrovna Undergraduate \\ Tambov state technical university \\ Tambov, Sovetskaya st., 106}

\author{
Krutko Konstantin Nikolaevich \\ Undergraduate \\ Tambov state technical university \\ Tambov, Sovetskaya st., 106
}

Основным показателем, характеризующим структуру пенопластов, является кажущаяся плотность (объемный вес), косвенно выражающая соотношение твердой и газообразной фаз в материале. Твердая фаза представляет собой полимер, распределенный в виде тяжей (стержней), вершин (узлов) и тонких оболочек (пленок), образующих ячейки, заполненные газом. Кажущаяся плотность пенопластов определяется истинной плотностью полимерной основы и газа, находящегося в ячейках. Она зависит от количества газообразователя и полимера-основы. Увеличение объемной доли полимера-основы приводит к уменьшению числа полостей в пенопласте и росту его плотности.

Характерной особенностью пенистых пластмасс является зависимость их механических показателей от кажущейся плотности. С её повышением, как и у большинства материалов, прочность и жесткость возрастают. Из вышесказан- 
ного возникает необходимость исследования зависимости механических свойств от объемного веса экструзионного пенополистирола [1].

С этой целью проводились кратковременные испытания поперечным изгибом и пенетрацией серий образцов, отобранных из плит ПЕНОПЛЭКС® различной плотности.

Для каждой серии опытным путем устанавливалась кажущаяся плотность, которая принималась равной среднему арифметическому значению плотностей 6 образцов. Плотность каждого образца вычислялась по известной массе и объему. Масса образцов определялась путем их взвешивания на весах с точностью 0,01 г. Объем рассчитывался по измеренным с точностью 0,1 мм геометрическим размерам, которые определялись как среднее арифметическое значение трех линейных измерений каждой стороны. Механические испытания материала проводились в помещении с температурой воздуха (22 \pm 5$)$ ${ }^{\circ} \mathrm{C}$ и относительной влажностью (50 \pm 5$)$ \% после предварительного статирования образцов при этих же условиях не менее 5 ч.

Влияние плотности экструзионного пенополистирола на прочность при поперечном изгибе оценивалось по изменению предела прочности Rизг, который определялся по результатам испытаний серий образцов-балочек с известным объемным весом [2]. Испытания проводились на многопозиционном стенде сериями с количеством образцов обеспечивающим возможность проведения статистической обработки полученных результатов. Образцы получали из стандартных полистирольных плит путем вырезания раскаленной струной. Форма образцов принималась 50х50х340 мм, что позволяет доводить материал до разрушения без "проскальзывания" между опорами.

Установлено, что с увеличением плотности экструзионного пенополистирола ПЕНОПЛЭКС囚 происходит рост его прочности при поперечном изгибе (рисунок 1). Связано это с увеличением доли полимера-основы в общем объеме пеноматериала. Тяжи становятся толще и воспринимают большую нагрузку. Максимальное значение предела прочности наблюдается у образцов с объемным весом близким к 40 кг/м3. При дальнейшем росте плотности материала прочность его практически не меняется.

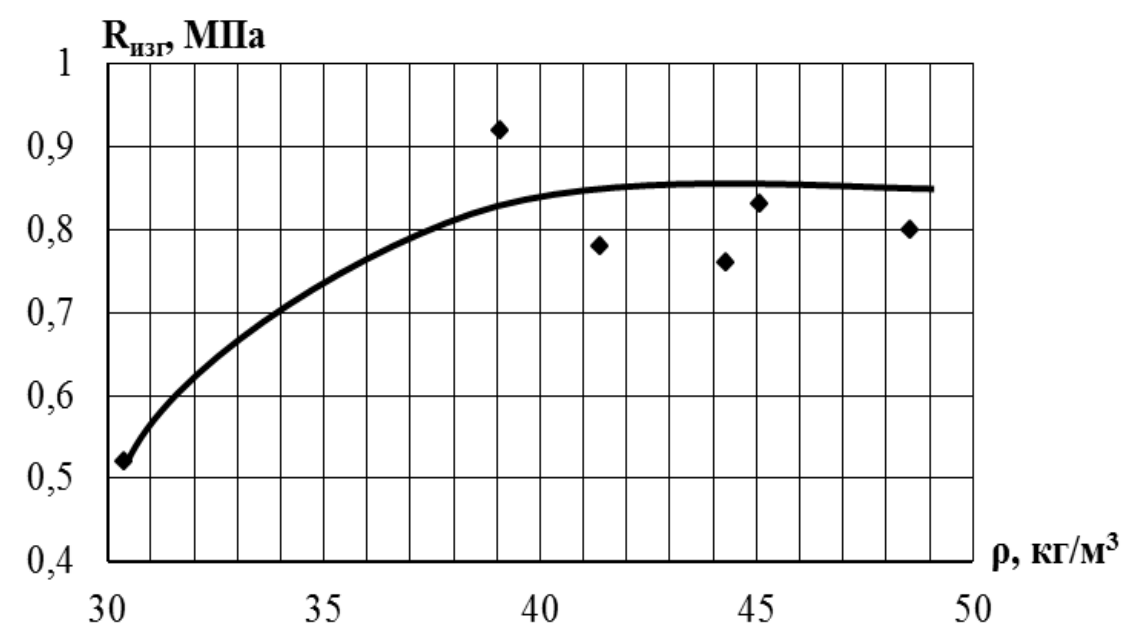

Рис. 1. Влияние плотности ( $\rho, к 2 / м 3)$ экструзионного пенополистирола ПЕНОПЛЭКС ${ }^{\circledast}$ на предел прочности при поперечном изгибе (Ruзг, MПа) 
Прочность при пенетрации образцов с разным объемным весом определялась по величине локальных напряжений, возникающих при вдавливании индентора (стального шарика диаметром 10 мм) при постоянной нагрузке (1,65 кг) в течение заданного времени (5 минут). За конечный результат принималось среднее арифметическое значение твердости (НВ, МПа) для серии образцов. Зависимость твердости экструзионного пенополистирола от кажущейся плотности представлена на рисунке 2.

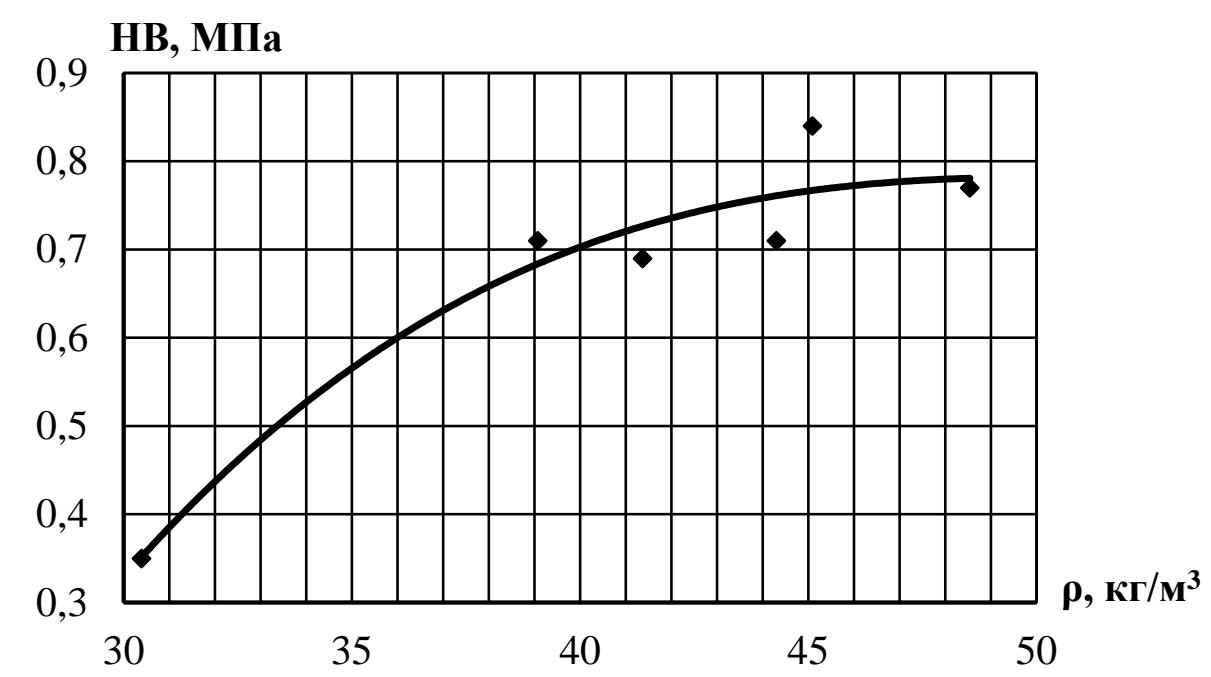

Pис. 2. Влияние кажущейся плотности (р, кг/м3) экструзионного пенополистирола ПЕНОПЛЭКС ${ }^{\circledR}$ на его твердость (НВ, МПа)

Очевидно, что с увеличением плотности растет величина локальных напряжений, а значит и твердость его поверхности. Наибольшей твердостью характеризуются образцы с объемным весом около 45 кг/м3. Такое поведение пенополистирола также связано с увеличением содержания полимера-основы и сокращения количества пор в материале.

Таким образом, полученные в ходе исследований результаты, соотносятся с приведенными в литературе положениями о влиянии объемного веса пенопластов на их механические характеристики. Прочность и жесткость экструзионного пенополистирола ПЕНОПЛЭКС® возрастают с повышением плотности. В небольших диапазонах колебаний плотности имеется линейная корреляционная связь между прочностью, и объемным весом пенополистирола. В широком диапазоне изменения плотности эта связь имеет параболический характер [3]. При повышении плотности выше некоторых критических значений повышение механических характеристик экструзионного пенополистирола значительно замедляется

Также на основе полученных результатов можно сделать вывод о возможности снижения расхода сырья за счет производства плит плотностью до 40 кг/м3. Использование таких плит в строительстве позволит обеспечить лучшую теплоизоляцию строительных объектов при сохранении основных механических характеристик экструзионного пенополистирола. Данное решение обладает высоким экономическим и экологическим потенциалом. Снижение антропогенной нагрузки на окружающую среду достигается за счет сокраще- 


\section{ния количества используемого сырья и энергозатрат на производство изделий} из экструзионного пенополистирола.

\section{Список литературы:}

1. Мамонтов А.А., Ярцев В.П., Струлев С.А. Анализ влажности различных утеплителей в ограждающих конструкциях здания при эксплуатации в отопительный период // Асаdетіа. Архитектура и строительство. 2013. № 4. С. 117-119.

2. Ярцев В.П., Мамонтов А.А., Струлев С.А. Оценка энергоэффективности ограждающих каркаснощитовых конструкций с различными утеплителями за отопительный период // Кровельные и изоляционные материалы. 2014. № 1. С. 26-27.

3. Ярцев В.П., Струлев С.А., Мамонтов А.А. Оценка экономической эффективности применения утеплителей в ограждающих конструкциях каркасно-щитовых зданий // Интернет-вестник ВолгГАСУ. Сер.: Политематическая. 2015. Вып. 1 (37). Ст. 12.

URL: http://www.vestnik.vgasu.ru/

\section{References:}

1. Mamontov A.A., Yartsev V.P., Strulev S.A. Analysis of humidity of various heaters in the protecting building designs at operation during the heating period // Academia. Architecture and construction. 2013. № 4 .

Pp. 117-119.

2. Yartsev V.P., Mamontov A.A., Strulev S.A. Assessment of energy efficiency of the protecting frame and panel board designs with various heaters for the heating period // Roofing and insulating materials. 2014. №1. Pp. 26-27.

3. Yartsev V.P., Strulev S.A., Mamontov A.A. Economic efficiency of application of heaters in the protecting designs of frame and panel board buildings // Internet messenger of VOLGGASU. It is gray.: Polythematic. 2015. Vol. 1 (37). Art. 12.

URL: http://www.vestnik.vgasu.ru/

(C) 2015, Струлева И.А., Крутько К.Н. О взаимосвязи плотности и прочности экструзионного пенополистирола
(C) 2015, Struleva I.A., Krutko K.N. About interrelation of density and durability of extrusive expanded polystyrene 


\title{
Красноруцкая О.Н., Бугримов Д.Ю., Савельева Ю.Е. Динамика критериев оценки заболеваемости ОРВИ у дошкольников на фоне применения иммуномодулирующей терапии
}

\author{
Krasnorutckaja O.N, Bugrimov D.Yu., Savelyeva Yu.E. \\ Dynamics of criteria for assessing the incidence of SARS in preschool \\ children during treatment with immunomodulatory therapy
}

Профилактика острых респираторных вирусных инфекций в детских организованных коллективах является наиболее важной проблемой современной сезонной педиатрической практики. Меры профилактики у детей требуют основательного методологического обоснования, и любое использование препаратов должно соответствовать главному принципу - не навредить детям

Ключевые слова: профилактика, острые респираторные вирусные инфекции,

организованные коллективы

\section{Красноруцкая Ольга Николаевна}

Кандидат медицинских наук, доцент

Воронежский государственный медицинский университет им. Н.Н. Бурденко

г. Воронеж, ул. Студенческая, 10

\section{Бугримов Даниил Юрьевич}

Кандидат медицинских наук, старший научный сотрудник

Воронежский государственный медицинский университет им. Н.Н. Бурденко

г. Воронеж, ул. Студенческая, 10

\section{Савельева Юлия Евгеньевна}

Заместитель главного врача

Воронежская городская поликлиника №1

г Воронеж, ул. 20-летия ВЛКСМ, 59
Preventive maintenance of the acute respiratory virus infections in the children's organized collectives is the most important problem of the modern seasonal pediatric practice. The measures of the preventive maintenance demand a thorough methodological substantiation from children, and any use of the medicaments should correspond to the major principle - not to do much harm to the children

Key words: preventive maintenance, acute respiratory virus infections, organized collective

\author{
Krasnorutckaja Olga Nikolaevna \\ Candidate of Medical Sciences, Associate Professor \\ Voronezh state medical university named N.N. \\ Burdenko \\ Voronezh, Studencheskaja st., 10 \\ Bugrimov Daniil Yurievich \\ Candidate of Medical Sciences, Senior Researcher \\ Voronezh state medical university named N.N. \\ Burdenko \\ Voronezh, Studencheskaja st., 10
}

Savelyeva Yuliya Eugenyevna

Deputy Chief

Voronezh city polyclinic №1

Voronezh, 20-letiya VLKSM st., 59

Проблема острых респираторных заболеваний в педиатрической практике приобретает наибольшую актуальность, так как в структуре общей первичной заболеваемости детей на их долю приходится больше случаев, чем на все 
остальные болезни вместе взятые. Частые респираторные заболевания, следующие одно за другим, способствуют развитию дисбаланса компенсаторноадаптационных механизмов организма ребенка и как следствие, формируется хроническая патология, возникают аллергические заболевания, обостряются латентные очаги инфекций и т.д. Острота данного вопроса у детей дошкольного возраста, определяется тем, что данный период характеризуется повышенной чувствительностью организма ребенка к респираторным инфекциям, обусловленной, прежде всего, отсутствием иммунологического опыта, необходимого для адекватного реагирования на микробную и вирусную агрессию, обилием возбудителей, процессом становления иммунной системы ребенка $[1,3]$.

Помимо медицинских аспектов проблема частой заболеваемости детей имеет и серьезные социально-экономические последствия, так в структуре временной нетрудоспособности 93-95 \% приходится на долю ухода за детьми, не говоря уже о расходах на их лечение [4]. Экономические потери от ОРЗ выше, чем от других инфекционных болезней [5].

В этой связи актуальность изучения организации и проведение работы по разноуровневой профилактике по снижению заболеваемости у детей дошкольного возраста, создание и развитие условий, способствующих сохранению и укреплению здоровья, заслуживает особого внимания и должна быть приоритетным в практике врача во всех возрастных группах. Внедрение в практику эффективных профилактических технологий позволяет сохранять здоровье детского населения, а это, в свою очередь, следует рассматривать как мероприятие, обеспечивающее медико-демографическую безопасность региона и страны в целом $[7,8]$.

Цель исследования: оптимизировать организацию профилактических мероприятий по снижению уровня заболеваемости острыми респираторными заболеваниями в дошкольных учреждениях.

Материалы и методы. Двойное слепое плацебо-контролируемое рандомизированное клиническое исследование проводилось с сентября 2011 года по апрель 2012 г в соответствии с Правилами проведения качественных клинических испытаний в РФ и Европейскими Предписаниями о GCP на базе МБДОУ «Детский сад общеразвивающего вида №46».Для решения поставленных задач были обследованы здоровые и часто болеющие в количестве 147 человек в возрасте от 2 до 6 лет. Продолжительность профилактической программы составила 8 месяцев.

После подписания формы информированного согласия законным представителем ребенка на участие в клиническом исследовании было проведено начальное обследование ребенка, включающее оценку состояния здоровья, сбор анамнеза, анализ посещения детского учреждения, уровень содержания slgA и плоские клетки поверхностного слоя эпителия. При соответствии критериям включения и отсутствии критериев исключения - методом случайной выборки ребенок был включен в одну из групп (согласно списку рандомизации) [2].

В исследовании использовался метод стратификационной рандомизации, что обеспечило однородность выборок групп по всем основным признакам: 
возрасту, полу, частоте заболеваний за период исследования, фоновой патологии. Таким образом, все обследуемые были разделены на четыре группы. Группа 1 - 30 пациентов, которые ежедневно получали дезоксирибонуклеат натрия (Деринат, производитель ЗАО «ФП «Техномедсервис»», Россия). Группа 2 - 30 пациентов получали интраназальное закапывание интерферона альфа (Гриппферон, производитель Биотехнологическая компания ФИРН М). Группа 3 - 30 пациентов получали интерферон лейкоцитарный человеческий жидкий в течение месяца сентябрь, ноябрь, январь, март, перерыв в месяц октябрь, декабрь, февраль. Группа 4 (контрольная) - 30 пациентов получали плацебо в упаковке (стерильный $0,1 \%$ раствор натрия хлорида).

Заболеваемость детей респираторными заболеваниями изучалась в течение исследуемого срока, а так же за год до проведения оздоровительных мероприятий по количеству эпизодов ОРЗ и количеству пропущенных дней по болезни путем просмотра поликлинических амбулаторных карт, а так же методом индивидуального обследования каждого ребенка, сбора анамнеза при непосредственном участии законного представителя.

Результаты исследования. Контингент детей МБДоУ «Детский сад общеразвивающего вида №46» по данным клинико-анамнестического анамнеза состоит из детей, следующих групп здоровья: I группа - 12, II группа - 54, III группа - 56, IV группа - 25. На диспансерном учете на 2011 г в детском саду состояло 37 детей что составляет - 25,2\%.

Установлено, что дети, включенные в исследование, в анамнезе страдали рецидивирующими бактериальными и вирусными инфекциями верхних дыхательных путей (не менее 3-4 раз за предыдущий год), кроме того, нами учитывалась и сопутствующая патология. У подавляющего большинства дошкольников отмечается наличие от 1 до 3 диагнозов в анамнезе, что свидетельствует о значительном снижении защитных сил детского организма.

Количество детей с хроническими заболевания вне обострения на момент первичного осмотра составило 55,1\% (81 чел.).

Отдельно была выделена группа часто болеющих детей острыми респираторными заболеваниями (не менее 6 раз за предыдущий год) количество которых составило 23 чел. У 30,4\% часто болеющих детей отмечались нарушения в психоэмоциональной сфере, проявляющиеся раздражительностью, повышенной утомляемостью.

Неблагоприятные факторы окружающей среды и неудовлетворительные жилищно-бытовые условия выявлены у 31,6\%, что также способствует снижению общей сопротивляемости организма, наличию очагов латентной инфекции, раннему развитию болезни, особенно у детей с отягощенной наследственностью по аллергическим заболеваниям. У 43\% детей анализ данных анамнеза позволил выявить наличие пассивного курения. 


\begin{tabular}{|c|c|c|c|c|c|c|c|}
\hline \multirow{2}{*}{$\begin{array}{c}\text { Этап иссле- } \\
\text { дования }\end{array}$} & \multirow{2}{*}{$\begin{array}{c}\text { годовой } \\
\text { период }\end{array}$} & 2010 год & \multicolumn{5}{|c|}{ 2011-2012 года } \\
\hline & & $\begin{array}{c}\text { средний } \\
\text { текущий } \\
\text { показатель }\end{array}$ & $\begin{array}{c}\text { средний } \\
\text { текущий } \\
\text { показатель }\end{array}$ & $\begin{array}{c}\text { группа } \\
1\end{array}$ & $\begin{array}{c}\text { группа } \\
2\end{array}$ & $\begin{array}{c}\text { группа } \\
3\end{array}$ & $\begin{array}{c}\text { группа } \\
4\end{array}$ \\
\hline 1 месяц & сентябрь & $12,8 \pm 1,4$ & $13,2 \pm 0,5$ & $14,2 \pm 0,3$ & $12,9 \pm 0,8$ & $12,8 \pm 0,6$ & $12,9 \pm 0,7$ \\
\hline 2 месяц & ктябрь & $10,4 \pm 0,5$ & $13,6 \pm 0,4$ & $14,8 \pm 0,4$ & $13,1 \pm 1,1$ & $13,1 \pm 0,5$ & $11,8 \pm 0,3$ \\
\hline 3 месяц & ноябрь & 10,2 & & $14,9 \pm 0,4$ & $13,2 \pm 0,7$ & $13,2 \pm 0,4$ & $10,1 \pm 0,3$ \\
\hline \multicolumn{2}{|c|}{$\begin{array}{c}\text { этапное среднее } \\
\text { значение }\end{array}$} & $11,8 \pm 0,3$ & $13,5 \pm 0,5$ & $14,6 \pm 0,3$ & $13,0 \pm 0,3$ & $13,0 \pm 0,8$ & $11,6 \pm 0,6$ \\
\hline 4 месяц & декабрь & $2 \pm 0,6$ & $12,9 \pm 0,1$ & $14,8 \pm 0,3$ & $13,1 \pm 0,3$ & $13,1 \pm 0,2$ & $11,2 \pm 0,4$ \\
\hline 5 месяц & & & & $14,3 \pm 0,8$ & $12,9 \pm 0,6$ & $12,5 \pm 0,1$ & $9,1 \pm 0,6$ \\
\hline 6 месяц & февраль & & & $14,6 \pm 0,5$ & $12,6 \pm 0,4$ & & \\
\hline \multicolumn{2}{|c|}{$\begin{array}{c}\text { этапное среднее } \\
\text { значение }\end{array}$} & $9,0 \pm 0,7$ & $12,4 \pm 0,1$ & $14,6 \pm 0,6$ & $12,8 \pm 0,3$ & $12,5 \pm 0,1$ & $9,8 \pm 0,3$ \\
\hline 7 месяц & март & $8,8 \pm 0,6$ & $11,9 \pm 0,3$ & $14,3 \pm 0,3$ & $12,1 \pm 0,2$ & $11,9 \pm 0,4$ & $9,1 \pm 0,2$ \\
\hline 8 месяц & & & & $14,2 \pm 0,6$ & $12,2 \pm 0,4$ & $=0,6$ & \\
\hline 9 месяц & май & & & $14,4 \pm 0,4$ & $12,4 \pm 0,4$ & $12,2 \pm 0,4$ & $\pm 0,2$ \\
\hline \multicolumn{2}{|c|}{$\begin{array}{l}\text { этапное среднее значе- } \\
\text { ние }\end{array}$} & $9,1 \pm 0,5$ & $11,9 \pm 0,2$ & $14,3 \pm 0,4$ & $12,2 \pm 0,4$ & $12,1 \pm 0,2$ & $9,0 \pm 0,3$ \\
\hline \multicolumn{2}{|c|}{$\begin{array}{c}\text { ИТОГОВОЕ } \\
\text { среднее значение }\end{array}$} & $9,9 \pm 0,2$ & $12,6 \pm 0,3$ & $14,5 \pm 0,3$ & $12,6 \pm 0,1$ & $12,5 \pm 0,3$ & $10,1 \pm 0,2$ \\
\hline
\end{tabular}

Анализ результатов исследования физического развития показал, что 19,6\% детей имеют дисгармоничное развитие. Сравнительная характеристика показателей посещаемости детьми дошкольного учреждения представлена в таблице №2. Средний показатель посещаемости детей в месяц в первом полугодии 2011 г. в среднем вырос на 18\%, чем за этот же период 2010 года, причем большую роль в этом сыграли дети из экспериментальной группы №1 (рост по сравнению с сентябрем 2010 года составил более 20\%). Средняя посещаемость детей в остальных экспериментальных группах достоверно не отличалась от этого показателя в сентябре 2010 года. Но, начиная со второго месяца исследования, наблюдался значительный рост (от 8 до 12\%) показателя средней посещаемости детей по всем экспериментальным группам (причем максимально - в 1 экспериментальной группе), кроме группы №4, где, наоборот, отмечалось снижением этого показателя на $10 \%$, что может свидетельствовать о начале сезонных заболеваний у детей.

Схожая динамика наблюдалась во все остальные сроки исследования, и по итогам составила: средняя продолжительность посещения детей в месяц составила 12,6, что на 26\% выше, чем показатель 2010 года. Максимальный рост наблюдался в 1 экспериментальной группе и составил 14,5, что выше в среднем на $18 \%$ чем во 2 и 3 группе и выше почти на $50 \%$, чем в 4 экспериментальной группе.

При анализе показателей заболеваемости воспитанников детского сада за последние 3 года (Таблица №3) наблюдается снижение количества заболеваемости ОРВИ с 76 до 42 случаев в год (в среднем на 45\%), причем максимальное снижение наблюдалось в период проведения исследования, т.е. в момент медикаментозной профилактики. Количество пропущенных воспитанниками дней в году пропорционально снижалось с 649 детодней до 403 детодней, 
а если учесть показатели за последние пять лет (Таблица №2), то этот показатель снижался с 701 до 403 детодней соответственно. При этом посещаемость за 5 лет возросла с 54\% до 86\% (в общем количестве детодней это составило 15861 и 16374 детодня соответственно) (Таблица №3).

Показатель заболеваемости частоболеющих детей снизился за 3 года на 12,5\%, а индекс здоровья возрос почти в 3 раза (максимальный пик повышения этого показателя наблюдался во 2-е полугодие 2011 года и в 1-е полугодие 2012 года, т.е. на момент проведения медикаментозной профилактики). Но при этом наблюдался парадоксальный эффект: если в среднем продолжительность

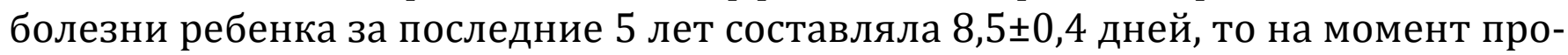
ведения исследования, при повышении общей посещаемости, повышения индекса здоровья и снижении количества частоболеющих детей наблюдалось увеличения средней продолжительности болезни воспитанника в первом полугодии 2012 года до 9,6士0,6 дней.

Такое состояние критерия может свидетельствовать о том, что на общем положительном фоне профилактических мероприятий продолжительность болезни увеличивалась у детей, не вошедших в группы исследования, и была равна среднему показателю по городу Воронеж.

Исходя из этих данных, можно сделать вывод, что применение иммунотропных препаратов в столь короткие сроки приводит к росту среднего посещения детей дошкольного образовательного учреждения, причем максимальный эффект: повышение показателя на 15\% установлен в группе №1 (после применения «Дерината»). Тем самым можно говорить о повышении устойчивости организма ребенка к сезонным заболеваниям.

При анализе заболеваемости в исследуемых группах в периоды эпидемического подъема заболеваемости ОРВИ и гриппа установлено, что применение препарата Деринат снижало уровень заболеваемости до 20\% (в среднем по группам он составлял 43\% (Гриппферон), 54\% (Интерферон лейкоцитарный человеческий жидкий), 76-80\% (в контрольных группах)). Большинство заболевших - 83\%, из первой экспериментальной группы имели легкое течение ОРВИ, и продолжительность их болезни составила 5,2士0,9 дня. В группах применения Гриппферона и Интерферон также наблюдалось превалирования легкого течения болезни (62\% и 56\% соответственно), а продолжительность течения в среднем составила 8-9 дней.

Показатели заболеваемости детей, не получавших профилактику ОРВИ и гриппа, а также воспитанников из группы «Плацебо»не отличались: доминировало тяжелое течение ОРВИ (2/3 детей), а продолжительность болезни составляла в среднем 12 дней.

Результаты указанных исследований свидетельствуют о хорошей профилактической эффективности, иммуномодулирующей активности и безопасности применения препарата Деринат. Профилактический прием препарата Деринат в течение 1 месяца продемонстрировал повышение иммунорезистентности детей, что подтверждается увеличением сроков посещаемости детского учреждения, отсутствием заболеваний на момент приема препарат. Все это 
позволяет рекомендовать включение данного препарата в программы иммунореабилитации и профилактики ОРВИ и ОРВЗ у детей.

Таблица №2. Средние показатели заболеваемости воспитанников детского сада в 2010-2012 годах (в расчете на 100 чел.)

\begin{tabular}{|c|c|c|c|c|c|c|}
\hline \multirow[b]{2}{*}{ Показатели } & \multicolumn{2}{|c|}{2010 год } & \multicolumn{2}{|c|}{2011 год } & \multicolumn{2}{|c|}{$\begin{array}{c}2012 \text { год } \\
\text { (1-е полугодие) }\end{array}$} \\
\hline & $\begin{array}{l}\text { Абсо- } \\
\text { лютное } \\
\text { коли- } \\
\text { чество }\end{array}$ & $\begin{array}{c}\text { Относи- } \\
\text { тельные } \\
\text { показа- } \\
\text { тели } \\
\text { на } 100 \\
\text { детей }\end{array}$ & $\begin{array}{c}\text { Абсо- } \\
\text { лют- } \\
\text { ное } \\
\text { коли- } \\
\text { чество }\end{array}$ & $\begin{array}{c}\text { Относи- } \\
\text { тельные } \\
\text { показа- } \\
\text { тели } \\
\text { на } 100 \\
\text { детей }\end{array}$ & $\begin{array}{c}\text { Абсо- } \\
\text { лют- } \\
\text { ное } \\
\text { коли- } \\
\text { че- } \\
\text { ство }\end{array}$ & $\begin{array}{c}\text { Относитель- } \\
\text { ные показа- } \\
\text { тели } \\
\text { на } 100 \text { детей }\end{array}$ \\
\hline $\begin{array}{l}\text { Количество случаев за- } \\
\text { болеваний в течение } \\
\text { года }\end{array}$ & 76 & - & 69 & - & 42 & - \\
\hline $\begin{array}{l}\text { Количество дней, про- } \\
\text { пущенных из-за забо- } \\
\text { леваний в течение года }\end{array}$ & 649 & $4,3 \%$ & 587 & $3,8 \%$ & 403 & $2,5 \%$ \\
\hline $\begin{array}{l}\text { Количество детей, ча- } \\
\text { сто болеющих ( } 4 \text { и бо- } \\
\text { лее раз в течение года) }\end{array}$ & 37 & $25,7 \%$ & 44 & $30,3 \%$ & 19 & $14,7 \%$ \\
\hline $\begin{array}{l}\text { Количество детей, не } \\
\text { болевших ни разу в те- } \\
\text { чение года ("индекс } \\
\text { здоровья") }\end{array}$ & 9 & $6,2 \%$ & 13 & $8,8 \%$ & 27 & $20,5 \%$ \\
\hline $\begin{array}{l}\text { Средняя продолжи- } \\
\text { тельность одного забо- } \\
\text { левания (в днях) }\end{array}$ & 8,5 & - & 8,5 & - & 9,6 & - \\
\hline
\end{tabular}

Одним из иммуноглобулинов играющим немало важную роль в здоровом респираторном тракте и в защите легких от болезней является секреторный иммуноглобулин A (sIgA).

Анализ уровня sIgA у исследуемых детей в первой группе (применение препарата Деринат) показал, что после 1 месяца введения уровень иммуноглобулина достоверно повысился на 30\% по сравнению с исходным уровнем $(\mathrm{p}<0,05)$, в том числе у юношей на 35\% (Таблица №3).

После месячного перерыва во введении Дерината наблюдалось относительное снижение уровня sIgA по сравнению с показателями 1 месяца, но эти величины оставались выше на 23-25\% по отношению к исходному уровню, в том числе и у юношей - на 27-28\%. Вторичное применение по схеме препарата Деринат вызывало достоверное $(\mathrm{p}<0,05)$ увеличение sIgA на 40\% по отношению к исходному уровню ( в том числе у юношей на 45\%).

Последующее применение препарата у первой группы исследуемых детей показала, что вторичный месячный перерыв во введении не вызывал существенного снижения уровня sIgA - он оставался выше исходного уровня на 36-38\% (в том числе и у юношей). Последнее, третье применение препарата 
в описываемой группе повысило уровень иммуноглобулина на 38\% по сравнению с исходным показателем (Таблица №3).

Таблица 3. Значения секреторного иммуноглобулина A (s/gA, п2/мл) в смывах носовых ходов у исследуемых объектов группы №1 (M士m)

\begin{tabular}{|l|c|c|c|c|c|c|}
\hline & $\begin{array}{c}\text { исходный } \\
\text { уровень }\end{array}$ & 1 месяц & 2 месяц & 3 месяц & 4 месяц & 5 месяц \\
\hline $\begin{array}{l}\text { Все исследуемые } \\
\text { (n=30) }\end{array}$ & $1,25 \pm 0,05$ & $1,65 \pm 0,01^{*}$ & $1,58 \pm 0,05$ & $1,64 \pm 0,02^{*}$ & $1,6 \pm 0,07$ & $1,62 \pm 0,04$ \\
\hline $\begin{array}{l}\text { В том числе } \\
\text { юноши } \\
(\mathrm{n}=15)\end{array}$ & $1,26 \pm 0,06$ & $1,71 \pm 0,02$ & $1,61 \pm 0,07^{*}$ & $1,71 \pm 0,02$ & $1,62 \pm 0,07$ & $1,69 \pm 0,03^{*}$ \\
\hline
\end{tabular}

Примечание: * - p<0,05, $n-$ количество исследуемых в группе

Таким образом, уровень секреторного иммуноглобулина А реагировал на применение препарата Деринат достоверным $(\mathrm{p}<0,05)$ повышением в среднем на 35-38\% по сравнению с исходным уровнем.

Курсовое использование препарата Гриппферон® во второй исследуемой группе детей показал, что уровень $\operatorname{IgA}$ достоверно $(\mathrm{p}<0,05)$ повышался в среднем на 15\% после первого месяца введения (в том числе и у юношей) (Таблица №4). Спустя месяц после первичного применения препарата во второй исследуемой группе значения секреторного иммуноглобулина А вернулись до исходного уровня, а у юношей наблюдалось даже незначительное (3\%), но достоверное $(\mathrm{p}<0,05)$ снижение.

Таблица 4. Значения секреторного иммуноглобулина A (s/gA, пг/мл) в смывах носовых ходов у исследуемых объектов группы №2 ( $\mathrm{M \pm m}$ )

\begin{tabular}{|l|c|c|c|c|c|c|}
\hline & $\begin{array}{c}\text { исходный } \\
\text { уровень }\end{array}$ & 1 месяц & 2 месяц & 3 месяц & 4 месяц & 5 месяц \\
\hline $\begin{array}{l}\text { Все исследуемые } \\
\text { (n=30) }\end{array}$ & $1,2 \pm 0,05$ & $1,35 \pm 0,01^{*}$ & $1,2 \pm 0,07$ & $1,35 \pm 0,05^{*}$ & $1,2 \pm 0,04^{*}$ & $1,4 \pm 0,05^{*}$ \\
\hline $\begin{array}{l}\text { В том числе } \\
\text { юноши } \\
(\mathrm{n}=15)\end{array}$ & $1,25 \pm 0,04$ & $1,36 \pm 0,03$ & $1,21 \pm 0,06^{*}$ & $1,36 \pm 0,04$ & $1,21 \pm 0,07$ & $1,41 \pm 0,03^{*}$ \\
\hline
\end{tabular}

Примечание: * - p<0,05, $n$ - количество исследуемых в группе

Вторичное применение по схеме препарата Гриппферон вызывало достоверное $(\mathrm{p}<0,05)$ повышение величины sIgA на 12-14\% (в том числе и у юношей). Очередной месячный перерыв во введении препарата достоверно снизил количество иммуноглобулина до исходного уровня. Заключительное применение препарата достоверно (p<0,05) повысило уровень секреторного иммуноглобулина А на 25-27\% (Таблица №4).

Таким образом, значения sIgA реагировали на курсовое применение препарата Гриппферон достоверным $(\mathrm{p}<0,05)$ повышением в среднем на 24-25\% по сравнению с исходным уровнем. При этом наблюдался эффект возвращения уровня иммуноглобулина до исходного в моменты перерыва во введении пре- 
парата, что может свидетельствовать о нестойкости количества sIgA при применении Гриппферона.

В третьей исследуемой группе после того, как исследуемые дети получали жидкий лейкоцитарный человеческий интерферон после 1 месяца применения уровень секреторного иммуноглобулина А повышался не более чем на 5 6\% по сравнению с исходным уровнем (Таблица №5).

Таблица 5. Значения секреторного иммуноглобулина A (slgA, пг/мл) в смывах носовых ходов у исследуемых объектов группы №3 (M士m)

\begin{tabular}{|l|c|c|c|c|c|c|}
\hline & $\begin{array}{c}\text { исходный } \\
\text { уровень }\end{array}$ & 1 месяц & 2 месяц & 3 месяц & 4 месяц & 5 месяц \\
\hline $\begin{array}{l}\text { Все исследуемые } \\
\text { (n=30) }\end{array}$ & $1,25 \pm 0,05$ & $1,3 \pm 0,05$ & $1,24 \pm 0,04^{*}$ & $1,24 \pm 0,01$ & $1,25 \pm 0,02$ & $1,29 \pm 0,02^{*}$ \\
\hline $\begin{array}{l}\text { В том числе } \\
\text { юноши } \\
\text { (n=15) }\end{array}$ & $1,25 \pm 0,02$ & $1,3 \pm 0,08$ & $1,24 \pm 0,02$ & $1,23 \pm 0,02$ & $1,26 \pm 0,05$ & $1,3 \pm 0,03$ \\
\hline
\end{tabular}

Примечание: * - p<0,05, $n-$ количество исследуемых в группе

Во время первого и второго месячного перерыва во введении препарата уровень sIgA возвращался до величин исходного уровня. Достоверно $(\mathrm{p}<0,05)$ значения показателя увеличивалось на 5\% лишь на 5 месяце эксперимента (в том числе и у юношей - на 6\%) (Таблица №5).

Таким образом, при введении жидкого лейкоцитарного человеческого интерферона уровень секреторного иммуноглобулина А повышался незначительно (не более 5-6\%), при этом во время месячных перерывов во введении препарата значения sIgA опускались до исходного уровня.

В четвертой (контрольной) группе у исследуемых, получавших плацебо в упаковке (стерильный 0,1\% раствор натрия хлорида), уровень секреторного иммуноглобулина А планомерно и достоверно $(\mathrm{p}<0,05)$ снижался на всем временном протяжении эксперимента в среднем на 30-40\% от исходного уровня. Причем у группы юношей снижение составило в среднем 25\%.

Таким образом, применение плацебо вызывало значительное снижение уровня $\operatorname{sg} A$ на всем протяжении исследования.

Анализ фармоэкономической эффективности применения препаратов по программе профилактики ОРЗ у воспитанников детского сада показал следующее: стоимость курсовой дозы: в первой группе она была максимальной и составила 199 рублей за первый этап. Стоимость курсовой дозы второй и третьей групп была 189 и 80 рублей соответственно. Таким образом, прямые расходы на профилактику ОРВИ 597 рублей для курсовой профилактики препаратом Деринат, 567 рублей для профилактики препаратом Гриппферон и 240 рублей для профилактики ОРВИ Интерфероном лейкоцитарным человеческим жидким.

Учитывая коээфициент эффективности профилактики, вычисляемого по формуле (1) на основе данных, представленных в таблице №8, профилактика Деринатом была эффективнее: коэффициент составил 80, что было на $70 \%$ больше, чем при профилактики гриппфероном (коэффициент - 57) и на 85\% 
больше, чем при профилактики интерфероном лейкоцитарным человеческим жидким (коэффициент - 47).

Таблица 6. Значения секреторного иммуноглобулина A (s/gA, п2/мл) в смывах носовых ходов у исследуемых объектов группы №4 (M士m)

\begin{tabular}{|l|c|c|c|c|c|c|}
\hline & $\begin{array}{c}\text { исходный } \\
\text { уровень }\end{array}$ & 1 месяц & 2 месяц & 3 месяц & 4 месяц & 5 месяц \\
\hline $\begin{array}{l}\text { Все исследуемые } \\
\text { (n=30) }\end{array}$ & $1,2 \pm 0,1$ & $1,0 \pm 0,05^{*}$ & $0,95 \pm 0,02$ & $0,8 \pm 0,05^{*}$ & $0,75 \pm 0,08$ & $0,75 \pm 0,05$ \\
\hline $\begin{array}{l}\text { В том числе юноши } \\
(\mathrm{n}=15)\end{array}$ & $1,2 \pm 0,01$ & $1,1 \pm 0,01^{*}$ & $1,1 \pm 0,02$ & $1,0 \pm 0,02$ & $0,9 \pm 0,05^{*}$ & $0,85 \pm 0,01$ \\
\hline
\end{tabular}

Примечание: * - p<0,05, $n-$ количество исследуемых в группе

Средняя стоимость суток терапии ОРВИ с учетом всех расходов на лекартсевнную терапию и анализо-дигностические мероприятия составляет 608 рублей при тяжелом течении заболевания и 360 рублей при легком течении. Учитывая уменьшение сроков течения болезни при применении препарата Деринат до 5,2, и снижении тяжести течения болезни до 80\% легкой формы, можно подсчитать, что терапия ОРВИ в таком случае составит 1870 рублей. При анализе терапии ОРЗ во 2 и 3 группе получилось, что стоимость курса составит 2808 и 2916 рублей соответственно, что почти в половину больше, чем при лечении той же нозологии, но при предварительной профилактики препаратом Деринат.

Кроме того, учитывая дополнительные расходы на лечение осложнений гриппа и ОРВИ, в среднем на одного человека, они составили 2470 рублей. Возникновение таких осложнений в 1 группе исследования составила всего 10\%, во второй и третьей $-28 \%$ и $39 \%$ соответственно.

Таким образом, отмечается не только лечебная эффективность применения препарата Деринат (снижения остроты заболевания, снижение сроков течения болезни, высокий коэффициент эффективности), но и экономическая эффективность профилактики (сметная стоимость продолжительности терапии на 1/3 меньше, чем в остальных группах, а если сравнивать стоимость курса профилактики - 597 рублей), то она в 4 раза дешевле, чем средняя стоимость терапии ребенка дошкольного периода и на 45-50\% эффективнее, чем профилактика гриппфероном и интерфероном лейкоцитарным человеческим жидким.

Таким образом, очевидно картина уменьшения сроков болезни и смягчения ее клинического течения при профилактическом применении препарата Деринат.

\section{Список литературы:}

1. Альбицкий В.Ю., Баранов А.А. Часто болеющие дети. Клинико-социальные аспекты, пути оздоровления. Саратов, 1986. 183 с.

2. Атауллаханов Р.И., Гринцбугр А.Л. Иммунитет и инфекция: динамическое противостояние живых систем // Детские инфекции. 2005. Т. 4. № 1. С. 11-21.

3. Вельтищев Ю.Е. Проблемы охраны здоровья детей России // Российский вестник перинатологии и педиатрии. 2000. № 1. С. 5-9. 
4. Ерофеева М.К. Профилактика гриппа и острых респираторных заболеваний в группах риска: автор. дис. д-ра мед. наук. СПб., 2002. 48 с.

5. Л.Г. Кузьменко и др. Иммунный статус здоровых детей // Вестник российского университета дружбы народов: медицина. 1999. № 2.1. С. 17-21.

6. Караулов А.В., Лиликов В.Ф. Иммунотерапия респираторных заболеваний // Поликлиника. 2004. № 4. C. 4-9.

7. Куинджи Н.Н., Раппопорт И.К. Профилактические осмотры детей в образовательных учреждениях: цели, реалии и пути решения проблемы // Поликлиника. 2008. №1. С. 20-22.

8. Малкоч А.В., Анастасевич Л.А., Боткина А.С.. Острые респираторные заболевания и возможности иммуномодулирующей терапии // Лечащий врач. 2008. № 8.

9. Рапопорт И.К., Котомина Е.В. и др. Заболеваемость по результатам профилактических медицинских осмотров детей дошкольного и младшего школьного возраста, посещающих образовательные учреждения Южного административного округа Москвы // Российский вестник перинатологии и педиатрии. 2005. № 1. С. 5-8.

(C) 2015, Красноруцкая О.Н., Бугримов Д.Ю., Савельева Ю.Е.

Динамика критериев оценки заболеваемости ОРВИ у дошкольников на фоне применения иммуномодулирующей терапии
(C) 2015, Krasnorutckaja O.N, Bugrimov D.Yu., Savelyeva Yu.E.

Dynamics of criteria for assessing the incidence of SARS in preschool children during treatment with immunomodulatory therapy 


\title{
Гущина Е.А., Вдовичева В.В., Тихомиров Г.А. О трисахаридах с точки зрения химика
}

\author{
Guschina E.A., Vdovicheva V.V., Tihomirov G.A. \\ About the trisaharidakh from the point of view of the chemist
}

Трисахаридами называют углеводы, состоящие из трёх остатков моносахаридов, связанных гликозидными связями. Наиболее важными представителями являются раффиноза, мелецитоза, генцианоза, солатриоза,целлотриозаи др. Свойства трисахаридовопределяются тем, к какому типу (восстанавливающих или не восстанавливающих) они относятся, а также их моносахаридным составом. Для получения трисахаридов часто используется частичный гидролиз высших полисахаридов. Основной задачей при получении трисахаридов из любого природного источника является выделение индивидуальных соединений из сложной смеси моно- и олигосахаридов

Ключевые слова: трисахариды, углеводы, раффиноза, моносахариды, химические свойства

\section{Гущина Елена Аркадьевна}

Кандидат химических наук, доцент

Нижегородская государственная сельскохозяйственная академия

г. Н. Новгород, пр. Гагарина, 97

\section{Вдовичева Валентина Владимировна \\ Кандидат химических наук, доцент \\ Нижегородская государственная медицинская академия \\ Н. Новгород, пл. Минина, 10/1}

\section{Тихомиров Геннадий Александрович}

Кандидат военных наук, профессор, заведующий кафедрой

Институт пищевых технологий и дизайна (филиал) НИЭУ

г. Н. Новгород, мкр. Щербинки, 21
Trisaharidami is called by the carbohydrates consisting of three remains of the monosaccharides connected by glikozidny communications. The most important representatives are a raffinoza, a meletsitoza, a gentsianoza, a solatrioza, a tsellotrioza, etc. Properties of trisakharid are defined by to what type (restoring or not restoring) they belong, and also their monosakharidny structure. For receiving trisakharid partial hydrolysis of the highest polysaccharides is often used. The main objective when receiving trisakharid from any natural source is allocation of individual connections from difficult mix mono - and oligosaccharides

Key words: trisakharida, carbohydrates, raffinoz, monosaccharides, chemical properties

\section{Guschina Elena Arkadyevna}

Candidate of Chemical Sciences, Associate Professor Nizhny Novgorod state agricultural academy Nizhny Novgorod, Gagarin ave., 97

\section{Vdovicheva Valentina Vladimirovna}

Candidate of Chemical Sciences, Associate Professor Nizhny Novgorod state medical academy Nizhny Novgorod, pl. Minina, 10/1

\section{Tihomirov Gennady Aleksandrovich}

Candidate of Military Sciences, Professor, Head of Department

Institute of Food Technology and Design (branch) NEEU

N. Novgorod, Shcherbinki ave., 21

Трисахариды относятся к углеводам и состоят из трёх остатков моносахаридов. Наиболее важными представителями трисахаридов являются раффиноза, мелецитоза, генцианоза, солатриоза, мальтотриоза, маннитотриоза, рам- 
ниноза, целлотриоза, микотриоза, плантеоза, бифуркоза, фукозиллактоза [1, c. $96 ; 2$, с. $417 ; 4$, с. $141 ; 6$, с. 173$]$.

Трисахариды, построенные из остатков одного и того же моносахарида, относятся к гомотрисахаридам. Их примерами служат:

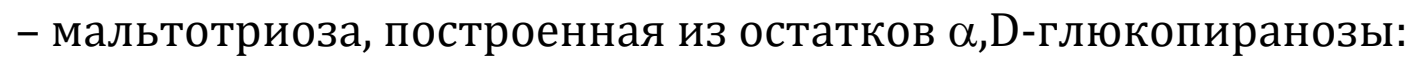

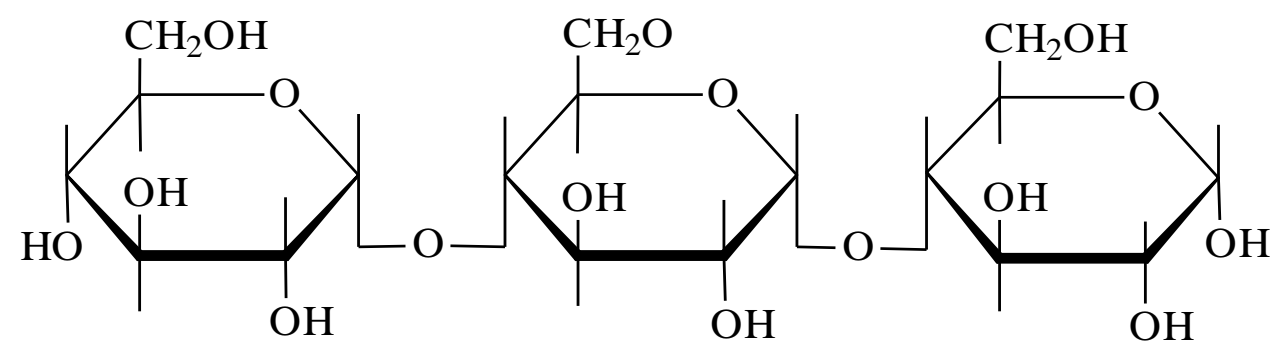

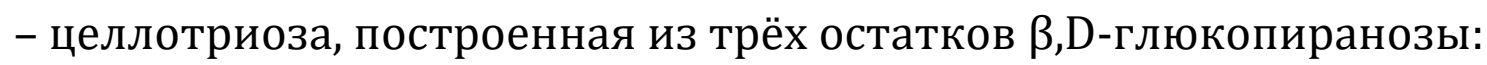

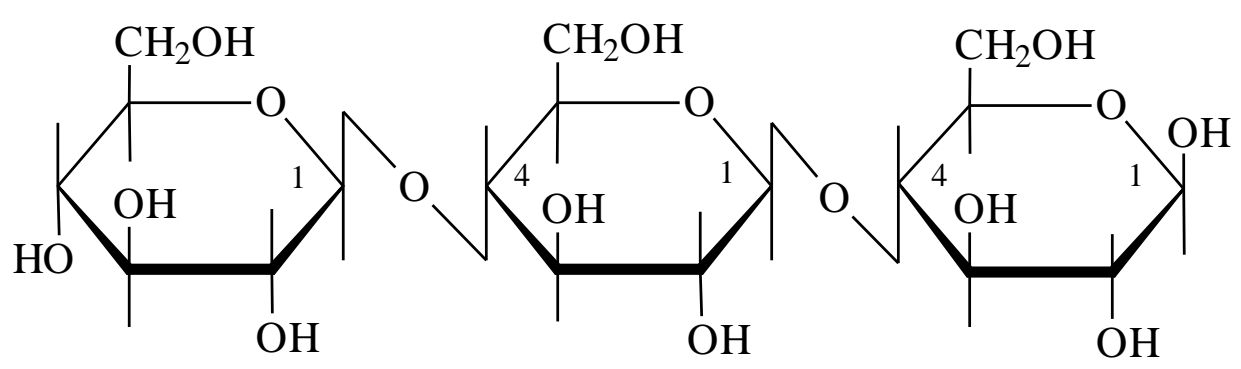

Если трисахариды состоят из остатков разных моносахаридов, то их относят к гетеротрисахаридам. Этих трисахаридов большинство. Одним из важнейших их представителей является раффиноза [1, с. 96; 4, с. 125]. Она содержится в сахарной свёкле, семенах хлебных злаков, риса, хлопчатника, бобовых растениях и высохшем соке эвкалипта (манне).

Раффиноза состоит из $\alpha, \mathrm{D}$-галактопиранозы; $\alpha, \beta$-глюкопиранозы и $\beta, \mathrm{D}-$ фруктофуранозы. Остаток галактопиранозы соединён с остатком глюкопиранозы гликозидной связью 1,6, а последний с остатком фруктофуранозы гликозидной связью 1,2:

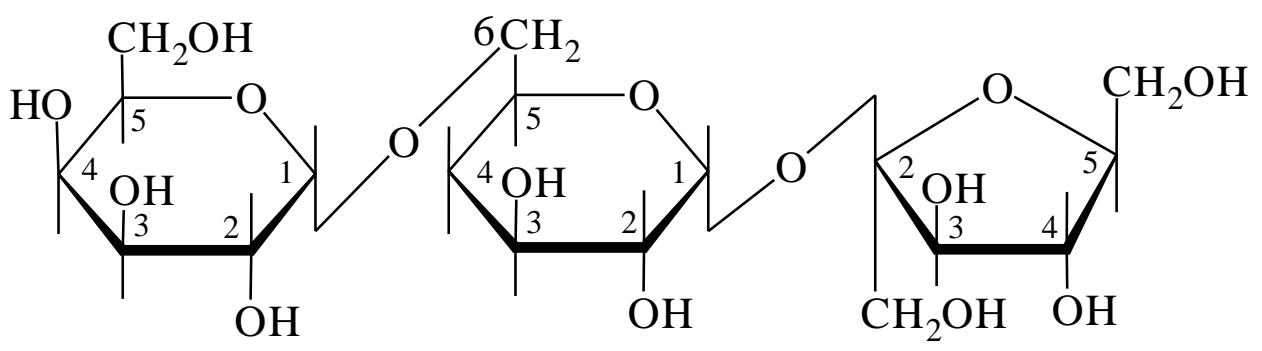

Трисахариды различаются строением входящих в них остатков моносахаридов, их последовательностью в цепи, наличием или отсутствием разветвлений, размерами цикла (фуранозной или пиранозной), а также конфигураци- 
ей гликозидных центров ( $\alpha-$, $\beta$-). Кроме того каждый моносахаридный остаток может соединяться гликозидной связью с любой гидроксильной группой соседнего остатка, включая полуацетальный гидроксил. Всё это в совокупности приводит к возникновению огромного числа возможных изомеров $[1,2]$. Так три разные гексозы, например D-глюкоза, D-галактоза и D-манноза, теоретически дают 4896 изомерных трисахаридов [5, с. 746].

Для названия олигосахаридов (трисахаридов в том числе) часто используются тривиальная номенклатура, обычно связанная с источниками получения вещества, и сокращённая запись структур, в которых остатки моносахаридов обозначаются тремя буквами (символами).

Например, глюкоза - Glc; манноза - Man;

галактоза - Gal; фруктоза - Fru;

рамноза - Rha; фукоза - Fuc.

После символа помещают буквы «р» или «f», обозначая этим пиранозную или фуранозную форму соответствующего моносахарида. Цифры в скобках обозначают положение гидроксильных групп, участвующих в межмолекулярной связи. Направление гликозидной связи указывается стрелкой.

Примеры сокращённой записи структур некоторых трисахаридов:

1. Раффиноза или $\alpha, D-$ Gal p $(1 \rightarrow 6) \alpha, D-$ Glc $p(1 \leftrightarrow 2) \beta, D-$ Fru f.

2. Мелетитоза или $\alpha, D-G l c p(1 \leftrightarrow 2) \beta, D-F r u f(3 \leftarrow 1) \alpha, D-$ Gle p.

3. Генцианоза или $\beta, D-G l c p(1 \rightarrow 6) \alpha, D-G l c p(1 \leftrightarrow 2) \beta, D-F r u f$.

4. Фукозиллактоза или $\beta, D-G a l p(1 \rightarrow 4) \alpha, D-G l c p$.

2
$\uparrow$
1
$\alpha, L-F u c p$

Фукозиллактоза вместе с другими олигосахаридами группы лактозы содержится в молоке млекопитающих. На её долю приходится около 10\% от общего количества сопровождающих лактозу олигосахаридов. Одна из функций олигосахаридов молока заключается в формировании бактериальной флоры в кишечнике новорождённых, необходимой для нормального пищеварения. В женском молоке содержание олигосахаридов, включая лактозу, составляет около трёх граммов в литре.

По химическим свойствам трисахариды подразделяются на восстанавливающие и невосстанавливающие. Если в молекуле трисахарида все гликозидные связи образованы полуацетальным гидроксилом одного и спиртовым гидроксилом другого моносахаридного остатка, то в конце цепи остаётся свободный полуацетальный гидроксил, способный таутомерно переходить в карбонильную группу. Такие трисахариды называются восстанавливающими и проявляют все свойства моносахаридов, в том числе дают реакцию Троммера и серебряного зеркала. Например, восстанавливающими трисахаридами являются мальтотриоза, целлотриоза, маннитотриоза, рамниноза, солактриоза и другие [2, с. 420].

Трисахариды, которые не содержат свободного полуацетального гидроксила, называются невосстанавливающими [1, с. 96]. Они проявляют только 
свойства многоатомных спиртов. Типичные представители: раффиноза, гентианоза (содержится в корнях горечавки) и мелецитоза (находиться в некоторых сортах манны, в листьях липы, в некоторых сортах мёда до 20\%).

Структурная формула мелецитозы имеет вид:

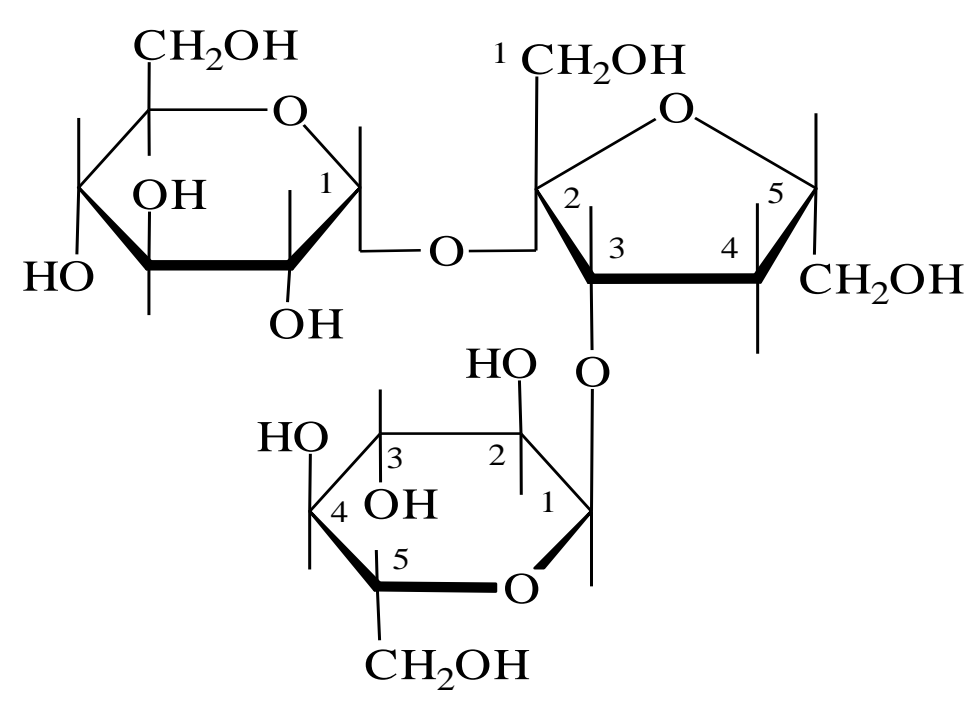

Большинство трисахаридов представляют собой бесцветные аморфные или кристаллические вещества. Они растворимы в воде, меньше растворяются в полярных органических растворителях и практически нерастворимы в неполярных [5, с. 749]. При нагревании трисахариды растворимы в пиридине и уксусной кислоте. Уксусная кислота особенно эффективна для проведения кристаллизации восстанавливающих трисахаридов, поскольку в среде уксусной кислоты мутаротационное равновесие устанавливается быстро, что ускоряет и облегчает кристаллизацию. Восстанавливающие трисахариды обычно кристаллизуются в виде одного определённого аномера и труднее, чем невосстанавливающие. Как аморфные, так и кристаллические трисахариды нередко плавятся в некотором интервале температур и, как правило с разложением [6, c. 175]. Многие трисахариды обладают слабым сладким вкусом (маннитриоза, рамниноза и другие). Раффиноза не имеет сладкого вкуса.

Наиболее характерной реакцией, свойственной всем трисахаридам, является их гидролиз, в результате которого происходит расщепление гликозидных связей и образование моносахаридов. Различают:

Кислотный гидролиз. Например, полный гидролиз раффинозы протекает таким образом:

$$
\begin{aligned}
& \mathrm{C} 18 \mathrm{H} 32 \mathrm{O} 16+2 \mathrm{HOH}=\mathrm{C} 6 \mathrm{H} 12 \mathrm{O} 6+\mathrm{C} 6 \mathrm{H} 12 \mathrm{O} 6+\mathrm{C} 6 \mathrm{H} 12 \mathrm{O} 6
\end{aligned}
$$

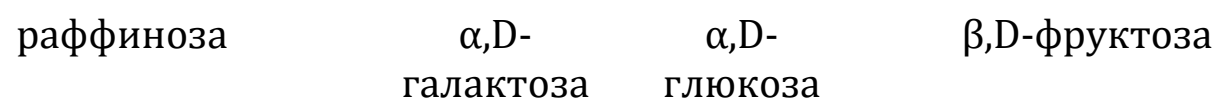

Ферментативный гидролиз. Например, раффиноза под действием фермента инвертазы распадается на фруктозу и дисахарид мелибиозу, состоящую из галактозы и глюкозы. С другой стороны гидролиз под действием фермента галактозидазы приводит к образованию галактозы и сахарозы. 
Кислотный и ферментативный гидролиз используются для установления моносахаридного состава и последовательности отдельных моносахаридов в цепи трисахарида. Окисление или восстановление карбонильной группы позволяет идентифицировать моносахарид, расположенный на восстанавливающем конце молекулы трисахарида. Превращение всех гидроксильных групп трисахарида в метиловые эфиры с последующим гидролизом и идентификацией метилированных моносахаридов (так называемый метод метилирования) служит химическим способом определения размера циклов (фуранозный, пиранозный) и расположения межмономерных связей в молекуле трисахарида.

Трисахариды, находящиеся в свободном состоянии в пищевых продуктах, извлекают водной экстракцией. Для получения трисахаридов часто используется частичный гидролиз высших полисахаридов [3, с. 201; 4, с. 140]. Основной задачей при получении трисахаридов из любого природного источника является выделение индивидуальных соединений из сложной смеси моно- и олигосахаридов. Для этой цели разработано несколько методов, основанных на хроматографии. Существуют и синтетические способы получения трисахаридов (ферментативный и микробиологический синтез).

\section{Список литературы:}

1. Брейтбург А.М. Биологическая химия. М.: Государственное издательство торговой лит-ры, 1959. $408 \mathrm{c}$.

2. Кочетков Н.К., Бочков А.Ф., Дмитриев Б.А., и другие. Химия углеводов. М.: Химия, 1967. 671 c.

3. А.Т. Солдатенков, Н.М. Колядина, В.Н. Буянов. Основы органической химии пищевых, кормовых и биологически активных добавок. М.: Химия, 2006. 278 с.

4. Нечаев А.П., Траубенберг С.Е., Кочаткова А.А. Пищевая химия. СПб.: ГИОРД, 2004. 640 с.

5. Химическая энциклопедия. Т. 3. М.: Большая Российская энцикл., 1992. 639 c.

6. Шорыгин П.П. Химия углеводов. М.: ОНТИ, 1938. 331 с.

(C) 2015, Гущина Е.А., Вдовичева В.В., Тихомиров Г.А.

О трисахаридах с точки зрения химика
(C) 2015, Guschina E.A., Vdovicheva V.V., Tihomirov G.A. About the trisaharidakh from the point of view of the chemist 


\title{
Киреева И.Ю. Особенности мониторинга биоразнообразия водных экосистем
}

\author{
Kirieieva I.Yu. \\ The monitoring features of aquatic biodiversity
}

В статье представлены теоретические подходы к организации биомониторинга водных экосистем для решения задач сохранения биоразнообразия и рационального использования биоресурсов гидросферы

Ключевые слова: мониторинг, биоразнообразие, экоситема, качество среды, индикаторы

\section{Киреева Ирина Юрьевна}

Кандидат биологических наук, доцент Национальный университет биоресурсов и природопользования Украины

Украина, Киев, ул. Генерала Родимцева, 19
The article presents the theoretical approaches to the organization of biomonitoring of aquatic ecosystems to meet the challenges of biodiversity conservation and sustainable usage of biological resources of the hydrosphere.

Key words: monitoring, biodiversity, ekositema, environment indicators

\author{
Kireeva Irina Yurievna \\ Candidate of Biological Sciences, Associate Professor \\ National university of life and environmental \\ sciences of Ukraine \\ Ukraine, Kiev, General Rodimtsev st., 19
}

Сокращение биоразнообразия занимает особое место среди основных экологических проблем современности. Биоразнообразие (БР) - “все многообразие форм жизни на земле, миллионов видов растений, животных, микроорганизмов с их наборами генов и сложных экосистем, образующих живую природу". Биоразнообразие характеризует процесс реальной эволюции, который идет на разных уровнях организации живой материи. На его основе создается структурная и функциональная организация биосферы и составляющих ее экосистем, которая определяет их стабильность и устойчивость к внешним воздействиям. [1, с.106; 5, с. 256-258; 12, 512с.].

БР рассматривают на 4-х уровнях: 1 - генетическом, 2 - популяционном, 3 - видовом, 4 - экосистемном. БР на видовом уровне охватывает весь набор видов на Земле (от бактерий и простейших до царства многоклеточных растений, животных и грибов), в более мелком масштабе - генетическое разнообразие видов географически отдаленных популяций и особей внутри одной популяции, а также разнообразие биологических сообществ, видов, экосистем, сформированных сообществами, и взаимодействия между этими уровнями. Для постоянного выживания видов и природных сообществ необходимы все уровни БР, они одинаково важны для человека. Понятие биоразнообразия все чаще является основой оценки состояния и экологического благополучия экоси- 
стем. Однако, ни одно живое существо, в том числе и человек, не может существовать просто как индивидуум. Для выживания необходимы популяций, имеющие генетические и динамические особенности, поскольку адаптация к резкому изменению любого фактора среды, идет, как правило, на популяционном уровне. Там, где не может приспособиться особь, обязательно адаптируется популяция, обеспечивая непрерывность жизни на Земле. Но и популяция устойчива и легче приспосабливается только при условии максимального разнообразия составляющих ее особей. Потомство от сохранившихся особей будет более жизнестойкое и выносливое. Поэтому возможности у живых существ в сохранении биосферы очень велики. Под действием факторов среды в том числе и антропогенного, число видов уменьшается, а различные виды живых организмов заносятся в Красные книги, что позволяет им на уровне видов сохраниться, или, наоборот, полностью исчезнуть. Для сохранения природных экосистем организуются охранные территории (биосферные заповедники, национальные парки, резерваты и т.д.). Сохранения разнообразия видов животных и растений решается в рамках популяционно-видового подхода, поскольку утрата видового разнообразия как жизненного ресурса может привести к серьезным глобальным последствиям для человека и даже его существования на Земле [3, 224c.; 4, 432c.].

Выделяют четыре основные антропогенные причины исчезновения видов: 1) утрата среды обитания, фрагментация и модификация; 2)чрезмерная эксплуатация ресурсов; 3) загрязнение окружающей среды; 4)вытеснение естественных видов интродуцированными и экзотическими. Генетическое разнообразие необходимо любому виду для сохранения репродуктивной жизнеспособности, устойчивости к заболеваниям, способности к адаптации в изменяющихся условиях и потому при уменьшении численности вида сокращается внутривидовая изменчивость, способная привести к серьезным генетическим изменениям, от которых вид уже не сможет оправиться. Потенциально вид может восстановить свою генетическую изменчивость благодаря мутациям, естественному отбору и рекомбинациям, но у вымирающего вида навсегда утрачиваются уникальность его генетической информации, содержащаяся в ДНК, и комбинации признаков. Если вид вымер, то его популяции уже не восстановимы, а сообщества, в которые они входили, безвозвратно обеднены и потенциальная ценность вида для человека окончательно утрачена. Становится неважным факт явного и фрагментарного разрушения местообитания, поскольку сообщества, его населяющие, могут быть глубоко затронуты деятельностью человека [6, 256c.].

Вместе с тем любая биологическая система (БС) на любом уровне организации живой материи является динамической, в ней постоянно протекает множество разновременных процессов. БС - открытые системы, условие существования которых обеспечивается обменом энергией, веществом и информацией между частями системы (или подсистемами), и с окружающей средой. Специфичность этого обмена заключается в контроле специальных механизмов реализации генетической информации и внутреннего управления, которые позволяют избежать «термодинамической смерти» путем использования 
энергии, извлекаемой из внешней среды. Устойчивость стабильных состояний БС (сохранение постоянства внутренних характеристик на фоне нестабильной или изменяющейся внешней среды), а также способность их к переходу из одного состояния в другое (свойство неустойчивости стационарных состояний биологических систем) обеспечиваются различными механизмами саморегуляции, базирующихся на принципе обратной связи (отрицательной или положительной). БС способны выдерживать изменениям среды и сохранять относительное постоянство состава, и свойства, т. е. обладают гомеостазом. Гомеостаз поддерживается на каждом уровне организации живого. На клеточном уровне эту функцию выполняют биомембраны (клеточные и внутриклеточные: плазматические, мембраны митохондрий, хлоропластов, лизосом, эндоплазматического ретикулума и др.). На тканевом уровне гомеостаз поддерживают тканевые жидкости, в том числе кровь и лимфа, а у растительных организмов - плазмодесмы, цитоплазматические нити, соединяющие соседние растительные клетки, которые регулируют межклеточные потоки углеводов и других субстратов. Гомеостаз генетический, или популяционный - способность популяции поддерживать относительную стабильность и целостность генотипической структуры в изменяющихся условиях среды, обеспечивается сохранением генетического равновесия частоты аллелей (возможных структурных состояний генов). Гомеостаз развития - способность данного генотипа создавать определенный фенотип в широком диапазоне условий. Понятие «гомеостаз» широко используется в экологии при характеристике состояния экосистем и их устойчивости, что характеризует поддержание постоянства видового состава и относительного обилия видов в экосистеме. Познание закономерностей гомеостаза имеет большое значение для выбора эффективных и рациональных методов диагностики и контроля состояния экосистем Нарушения механизмов сохранения постоянства гомеостатических процессов, рассматриваются как «болезни гомеостаза» $[1,106 c . ; 5$, с.256-258; 6, 256c.; 8, 47с.; 12, 512c.].

Основной метод оценки состояния биологических систем - мониторинг многократные измерения для слежения за изменением какого-либо параметра в некотором интервале времени; система долгосрочных наблюдений, оценки, контроля и прогноза состояния и изменения объектов. Экологический мониторинг - это система постоянных наблюдений за состоянием среды обитания и населяющих ее организмов и определенная методология таких наблюдений, базирующаяся на естественнонаучной основе (биологические, физикохимические и другие методы контроля качества среды обитания и состояния популяций и экосистем, математическое моделирование, геоинформационные технологии и т. д.), и на основе фундаментальных социально-экономических знаний $[4,432 c$.$] .$

Важная составная часть экомониторинга - мониторинг биологического разнообразия (МБР) - система регулярных длительных наблюдений в пространстве и времени, дающая информацию о состоянии биоразнообразия во всех его проявлениях с целью оценки прошлого, настоящего и прогноза будущих параметров биоразнообразия, поддерживающих естественный гомеостаз 
экосистем, а также имеющих значение для жизнедеятельности человека. Основные функции МБР - контроль за состоянием биоразнообразия на различных уровнях организации биологических систем: на субклеточном (генетические, биохимические и биофизические аспекты); клеточном и тканевом (иммунологические, эмбриологические, гистологические и органные аспекты); организменном (физиологические аспекты); видовом, популяционном и экосистемном (многообразие организмов, популяций, сообществ, ландшафтов) уровнях. К методическим подходам проведения мониторинга биоразнообразия относятся: 1) панбиотическая таксономическая инвентаризация (AВТI), базирующаяся на нескольких ключевых группах видов, которые, считаются хорошими индикаторами состояния тех или иных экосистем (например, рыбы или бабочки); 2). пантаксономическая инвентаризация биоразнообразия (ATBI), направленная на описание всех видов, обитающих на определенной территории; 3) быстрая оценка состояния биоразнообразия (RBA), опирающаяся на списки избранных видов, дающих оперативный показатель биологического богатства территории. Мониторинговые программы могут также фокусироваться на состоянии генетического разнообразия видов, на ключевых видах, ключевых местообитаниях или на их сочетаниях [1, 106с.; 4, 432 с.].

Не менее важным компонентом экомонторинга является мониторинг качества окружающей среды, позволяющий оценить абиотические (химические параметры воздуха, воды, почв и пр.) и биотические изменения (изменения в составе, обилии, распространении видов и сообществ) в экосистеме.

Водные экосистемы благодаря особой роли воды на планете и крайней важности фундаментальной экологической границы вода-суша, играют в сохранении биологического разнообразия особенно значимую, каркасную роль. Существенное отличие водных экосистем от сухопутных - это особенности их функционирования и ответные реакции на антропогенное действие. Необходимо отметить, что пресноводные экосистемы (озера, реки, пруды, ручьи, родники, водно-болотные угодья) отличаются значительно большим разнообразием абиотических характеристик, чем морские и океанические. Кроме того, человеком созданы разные категории искусственных водоемов. Следует учитывать, что внутренние водные экосистемы характеризуются большим биоразнообразием и число эндемичных видов, а также большим количеством видов, находящихся в депрессивном состоянии или под угрозой исчезновения. Вместе с тем, водные экосистемы включают дикую живую природу и водные пространства, жизненно-необходимые для мигрирующих видов. Многие внутренние водоемы продолжают сохранять огромное экологическое значение для человечества (морские гидробионты формируют около 1/3 кислорода планеты, являются ценным источником протеинов и смягчают глобальные климатические изменения; обеспечивают прохождение круговоротов вещества, энергии, информации; водный туризм)

К основным антропогенным воздействиям на пресноводные экосистемам относятся: изменение речного стока в результате гидростроительства, безвозвратные потери воды при ее заборе воды в целях регулирования паводков или для ведения сельского хозяйства, уничтожение нерстовых площадей, интро- 
дукция инвазивных чужеродных видов, загрязнение окружающей среды, браконьерство нерегулируемый промысел рыбы, последствия методов рыболовства, сток наносов с суши последствия изменения климата, снижение активности всех процессов образования и разрушения органического вещества, включая процессы первичного и вторичного его продуцирования. Воздействие этих факторов ощущается мировом масштабе, но их последствия будут различны в разных водосборных бассейнах, и очень часто их воздействие недооценивается (сокращение или утрата биоразнообразия морских и прибрежных районов на глобальном, региональном и национальном уровнях.

Важный компонент МБ - мониторинг качества среды, позволяющий оценить абиотические (химические параметры воздуха, воды, почв и пр.) и биотические изменения (изменения в составе, обилии, распространении видов и сообществ) в экосистеме с целью: 1) проведения инвентаризации, имеющихся в районе видов и местообитаний в их взаимосвязи; 2) разделения естественных флуктуаций (например, нормальных колебаний численности видов) от изменений, вызванных катастрофическими причинами (гибель животных и растений под влиянием загрязнений, разливов нефти и др.); 3) вскрытия причинноследственных отношений между внешними факторами и изменениями в популяциях видов или в экосистемах в целом. Таким образом, мониторинг является инструментом для измерения эффективности мероприятий, проведенных по сохранению биоразнообразия, и по выявления природных и антропогенных биологических тенденций [6, 256с.; 7, с. 318].

Для контроля качества среды обитания в биомониторинге используют биоиндикаторы-организмы или сообщества организмов, присутствие, количество или особенности развития которых, служат показателями естественных процессов и условий или антропогенных изменений среды обитания. Многие из них очень чувствительны и избирательны по отношению к различным факторам среды (химическому составу почвы, вод, атмосферы, климатическим и погодным условиям, присутствию других организмов и т. п.) и часто характеризуются узким диапазоном экологической валентности в диапазоне изменения этих факторов (скопления морских рыбоядных птиц свидетельствует о подходе косяков рыб).

Следует указать, что мониторинг водной среды отработан наиболее эффективно. Специфические организмы планктона и бентоса указывают на происхождение водных масс и течений, характеризуют определенные параметры среды обитания (соленость, температура и т.п.). Локальные внутривидовые группировки у многих животных (рыбы) имеют в зависимости от района обитания различные комплексы паразитов-индикаторов. При помощи биоиндикаторов устанавливают содержание в субстрате биологически активных веществ, определяют интенсивность различных химических (рН, содержание солей и др.) и физических (радиоактивность и др.) факторов среды. Важный аспект биоиндикации - оценка загрязнения окружающей среды (биотестирование) и постоянный контроль ее качества и изменений (биомониторинг). Так, после аварийного разлива нефти резко увеличивается численность углеводородокисляющих бактерий (на 3-5 порядков величины). Если в чистых водных 
экосистемах они составляют обычно менее 0,1\% от общего микробного населения, то в экосистемах океана, загрязненного нефтью, их доля может составить 100\%. Гетеротрофные индикаторные бактерии объединяют в группы в зависимости от используемого субстрата (гексадекан - окисляющие, бенз(а)пирен - трансформирующие, ксилол-трансформирующие, полихлор бифенил - транс- формирующие). Определение индикаторных групп бактерий положено в основу микробного тестирования распространения тех или иных загрязняющих веществ в различных экосистемах $[13,496 c$.$] .$

Известны разные методы оценки состояния и динамики биоразнообразия на разных иерархических уровнях организации водных биосистем: 1) Биолюминесценция (свечение), которая широко распространена в природе и известна у бактерий, грибов, представителей разных типов животных - от простейших до хордовых. Наиболее часто в качестве биоиндикаторов используют морские люминесцентные бактерии, у которых специальными приборами измеряют изменение интенсивности свечения под действием токсикантов [2, 298 с.]. Отклик люминесцентных бактерий на токсические вещества достоверно коррелирует с таковым у других биологических организмов, а величина 50\% тушения свечения (EC50) достоверно коррелирует с величиной 50\% летальной дозы (LD50) для человека. 2).Фотосинтетическая активность - по первичной продукции, характеризующей исходный уровень биологической продуктивности и поток энергии по пищевым цепям. Ее оценивают по изменению интенсивности флуоресценции хлорофилла при переходе фотосинтетического аппарата из активного состояния в неактивное. У водорослей выявлена корреляция параметра переменной флуоресценции с фотосинтетической продукцией клеток фитопланктона, определенной по скорости выделения кислорода или по фиксации CO2 [5, с. 256-258]. Кроме того, этот метод используется при анализе сточных вод, при определении содержания нефтепродуктов в водной среде. На основе флуоресцентных методов в комбинации с лазерной оптикой разработаны приборы для дистанционного контроля состояния экосистем и содержания в них отдельных загрязняющих веществ. Эти методы наряду с другими используются в космическом мониторинге [13, 496 с.]; 3) Генетические методы (изменение и структурные изменения хромосом)- характеризует мутагенную активность среды, а наличие таких аномалий можно использовать в качестве индикатора стресса, вызывающего образование аномальных клеток и снижение устойчивости иммунной системы 4).Биоэнергетические методы позволяют установить снижение качества среды до повреждающего действия загрязнений на организм, когда регистрируются ранние изменения в физиологическом гомеостазе по показателям интенсивности энергетического метаболизма особи (метод респирометрии). Количество энергии, расходуемой на процессы роста особи в стрессовых условиях, всегда выше, чем в оптимальных, из-за дополнительных затрат энергии на компенсацию таких воздействий, поэтому количество энергии, затраченная в период роста, является характеристикой качества среды [11, 237 с.]. 5) Иммунологические методы - позволяют фиксировать возникновение заболеваний или антигенное воздействие по изменению состава и численности иммунокомпетентных клеток, и появлению 
специфических компонентов [3, 224c.; 11, 237 с.]; 6). Патологоанатомические и гистологические методы - позволяют обнаружить влияния сильных токсических агентов по серьезным перестройкам в структуре и функции клеток, регистрируемые на тканевом уровне, а также и любое нарушение развития половых клеток и гонад, которые можно рассматривать как сигнал о наличии неблагоприятных изменений. Особенно широко эти методы используются для оценки последствий различных видов стрессового воздействия в отношении рыб; 7). Токсикологические методы - оценивают действие токсичных свойств веществ с использованием модельных живых систем в лабораторных условиях( тест-систем - культуры водных организмов: ракообразных (дафнии), водорослей или бактерий $[9,120 c . ; 10,156$ с.]; 8). Эмбриологические методы - базируются на уязвимости ранних стадий развития организма к воздействию внешних факторов. На стадии дробления и на стадии формирования зародышевых органов и тканей даже незначительные воздействия, как правило, приводят к видимым уродствам на более поздних стадиях или даже гибели зародышей. Как тест-объекты используют быстро развивающиеся и дающие многочисленное потомство животных (рыбы, моллюски, земноводные, насекомые). При выборе объекта учитывают легкость культивирования [8, 47 с.]; 9) Эколого-биохимические методы - основаны на изучении биологии гидробионтов. Несмотря на то, что гидросфера, как среда жизни, наиболее сложна для мониторинговых исследований, на водоемах возможно проведение мониторинга высокого уровня - эколого-биохимического контроля химических, гидрологических и гидробиологических показателей. Именно особенности биологии гидробионтов (рыб) позволяют уловить малейшие изменения в их обмене веществ еще до появления морфологических, физиологических, популяционных и других отклонений от нормы. Поэтому ранняя диагностика метаболизма гидробионтов фиксирует поступление в воду даже ничтожных количеств загрязнений и позволяет проводить эколого-биохимический мониторинг. При разработке мер по сохранению биоразнообразия морей необходимо учитывать многолетние колебания видового состава гидробионтов, обусловленные природными процессами. Система эколого-биохимического мониторинга необходима для контроля за биологическим состоянием еще не загрязненных токсикантами территорий акватории, и для выяснения причин различных патологий, возникающих под влиянием антропогенного стресса, их динамики во времени. Ее можно использовать в экспертизах и при арбитражах, связанных с различными отравлениями живых организмов промышленными и сельскохозяйственными выбросами.

Таким образом, мониторинг водных экосистем, разработка и внедрение новых методов сбора и обработки информации о биоразнообразии, структурно-функциональной организации и основных видах антропогенного воздействия на экосистемы водоемов, внедрение современных ГИС технологий, создание региональных кадастров гидробионтов остается главным методом контроля и сохранения видового разнообразия гидросферы, как одной из сред жизни, и биосферы в целом. 


\section{Список литературы:}

1. Балушкина Е.В. Методы биологического анализа пресных вод. Л.: ЗИН АН СССР, 1976. С. 106.

2. Данилов В.С., Егоров Н.С. Бактериальная биолюминесценщия. М.: МГУ, 1985. 298 с.

3. Кондратьева И.А., Киташов А.В., Рокк Ф. Применение иммунологических методов при изучении иммунозащитных реакций у рыб и беспозвоночных животных. Практикум по иммунологии. М.: МГУ, 2001. $224 \mathrm{c}$.

4. Лебедева Н.В., Криволуцкий Д.А., Пузаченко Ю.Г. География и мониторинг биоразнообразия. М.: Научный и учебно-методический центр, 2002. 432 c.

5. Маторин Д.Н., Венедиктов П.С., Конев Ю.Н., Казимирко Ю.В., Рубин А.Б. Использование двухвспышечного импульсного погружного флуориметра для определения фотосинтетической активности природного фитопланктона // Докл. РАН, 1996, Т. 350. № 2. С. 256-258.

6. Примак Р. Основы сохранения биоразнообразия. М.: Издательство Научного и учебно-методического центра, 2002. 256 c.

7. Руководство по гидробиологическому мониторингу пресноводных экосистем.

СПб: Гидрометеоиздат, 1992. 318 c.

8. Софронов Е.А., Румак П.С., Поздняков С.П., Умнова Н.В., Бовтюшенко В.Г. Медико-биологические основы оценки опасности экотоксикантов. СПб.: ВмедА, 1999. 47 c.

9. Федоров В.Д., Капков В.Н. Руководство по гидробиологическому контролю качества природных вод.

М.: Христианское изд-во, 2000. 120 с.

10. Филенко О.Ф. Водная токсикология. М.: МГУ-Черноголовка, 1988. 156 с.

11. Хаитов Р.М., Пинегин Б.В., Истамов Х.И. Экологическая иммунология. М.: Изд. ВНИРО, 1995. 237 с.

12. Шилов И.А. Экология. Учебник. М.: Высшая школа, 1997. 512 с.

13. Экологическая диагностика: Энциклопедия (серия «Безопасность России»). М.: МГФ Знание-

Машиностроение, 2000. 496 c.

(C) 2015, Киреева И.Ю.

Особенности мониторинга биоразнообразия водных экосистем
(C) 2015, Kirieieva I.Yu.

The monitoring features of aquatic biodiversity 


\title{
Ягафарова Г.А., Кужина Г.Ш. \\ Содержание марганца в почвах д. Кирдасово Абзелиловского района Республики Башкортостан
}

\author{
Yagafarova G.A., Gugina G.Sh. \\ Manganese content in the ground was carried out in the \\ Republic of Bashkortostan, in the village of Abzelilovsky region
}

Исследовано содержание марганца в почвах д. Кирдасово Абзелиловского района Республики Башкортостан. Установлено, что во всех точках отбора содержание изучаемого элемента в почвах данного региона превышает ПДК

Ключевые слова: марганец, почва, конщентрация

Ягафарова Гульсина Азатовна

Кандидат биологических наук, доцент

Сибайский институт (филиал) Башкирского

государственного университета

Башкортостан, г. Сибай, ул. Белова, 21

Кужина Гульнара Шарифбовна

Кандидат биологических наук, старший

преподаватель

Сибайский институт (филиал) Башкирского

государственного университета

Башкортостан, г. Сибай, ул. Белова, 21
Research of manganese content in the ground was carried out in the Republic of Bashkortostan, in the village of Abzelilovsky region. It was stated that content of this element in the ground of this region is above the maximum concentration limit in all sampling points

Key words: manganese, ground, concentration

Yagafarova Gulsina Azatovna

Candidate of Biological Sciences, Associate Professor Bashkort state university in Sibay

Bashkortostan, Sibay, Belova st., 21

Gugina Gulnar Sharifovna

Candidate of Biological Sciences, Senior Lecturer

Bashkort state university in Sibay

Bashkortostan, Sibay, Belova st., 21

Почва является неотъемлемой частью любого наземного биогеоценоза и биосферы в целом. При этом она выполняет ряд экологических функций, в том числе глобальных биосферных, обеспечивающих стабильность биосферы и саму возможность существования жизни на Земле. Выполняя важные функции, почва влияет на химический состав воздуха, атмосферных осадков, определяет макро- микроэлементный химический состав растений [6].

Марганец - один из наиболее распространённых микроэлементов в литосфере, его содержание в горных породах изменяется в пределах $350-2000$ мг/кг [7]. Он распространён в почвах в виде оксидов и гидроксидов, осажденные как на почвенных частицах, так и в виде конкреций различного диаметра, способных концентрировать железо и некоторые другие микроэлементы почв. 
Он образует ряд минералов, в которых он обычно присутствует в виде ионов Mn2+, Mn3+ и Mn4+, однако наиболее распространённым в породообразующих силикатных минералах является его окисленное состояние +2 . При выветривании в атмосферных условиях соединения марганца окисляются, а образующиеся при этом оксиды вновь осаждаются и формируют вторичные минералы.

Распределение марганца в почвенной толще весьма неоднородно. Он может накапливаться в различных почвенных горизонтах, особенно в обогащённых оксидами и гидроксидами железа, однако обычно элемент аккумулируется в верхнем слое почв за счёт фиксации органическим веществом [7].

Поведение марганца в почвах исключительно сложное и зависит от различных факторов. Одним из важных факторов, определяющих подвижность марганца, является реакция среды. Почвы кислого интервала отличаются повышенным содержанием марганца, почвы, имеющие нейтральную реакцию, содержат его значительно меньше [4]. Факторам, влияющим на накопление марганца в почве, а также относят и климатические условия [3].

Причинами повышенного содержания марганца в почвах могут быть как естественные геохимические аномалии, так и техногенное загрязнение. Природные факторы предопределяются геологическим строением территории, прежде всего химическим составом руд и вмещающих их пород.

Исследование содержания марганца в почвах является информацией о количестве и динамике содержания его в почвах, и полученные данные будут являться основой для проведения экологического мониторинга исследуемого региона.

В качестве объектов исследования использовали образцы почв д. Кирдасово Абзелиловского района Республики Башкортостан, который занимает срединную часть Башкирского Зауралья и имеет общую границу с Челябинской областью. Восточная половина территории района - равнинно-степная, западная - горно-лесная. Горно-лесную зону образуют хребет Уралтау и Ирендык с северным продолжением Крыктытау, которые возвышаются на 600-1000 м.

Почвы на склонах из грубоскелетных маломощных черноземов, на равнинах - выщелоченные полноразвитые. Хребет Уралтау покрыт березовососновыми и березово-лиственничными лесами, почвенный покров представлен серыми лесными и подзолистыми почвами. Восточная часть района занята грядово-мелкосопочной равниной с пологим уклоном к долине р. Урал. Высота местности колеблется в пределах 350-400 м.

Относительно суровые климатические условия оказывают влияние на микробиологическую деятельность и на биологическую активность почв. Этим объясняется слабая минерализация гумуса, невысокие запасы элементов питания растений в доступной форме.

На территории района наиболее выражены минеральные и рекреационные ресурсы. Здесь имеются достаточно крупные месторождения рудных полезных ископаемых магматического и метаморфического происхождения. Район богат месторождениями марганца. Наиболее крупными его месторождени- 
ями являются Ниязгуловское, Кусимовское, Габдиновское, Елимбетовское. Мощность рудных залежей на последнем колеблется от 5 до 8 м, среднее содержание марганца в руде 14-17 \% . Наиболее известно Кусимовское месторождение марганца, из которого во время Великой Отечественной войны добывали марганец и использовали в металлургическом комбинате г. Магнитогорска [1].

Отбор образцов почв был отобран из слоя 0-10 см методом «конверта» из четырех точках исследуемого района. Хранение почвенных образцов были проведены в соответствии с общепринятой методикой отбора проб для почвенного мониторинга [5]. В отобранных почвенных образцах определялось содержание марганца методом атомной абсорбции в Центральной лаборатории СФ ОАО «УГОК» г. Сибай Республики Башкортостан. Загрязненность почв металлом оценивали по показателю предельно допустимой концентрации.

Результаты наших исследований свидетельствуют, что почвенный покров исследуемого участка имеет различный уровень содержания марганца. Наиболее высоким содержанием марганца отличается точка 4, а наименьшим точка 3. (рис.1).

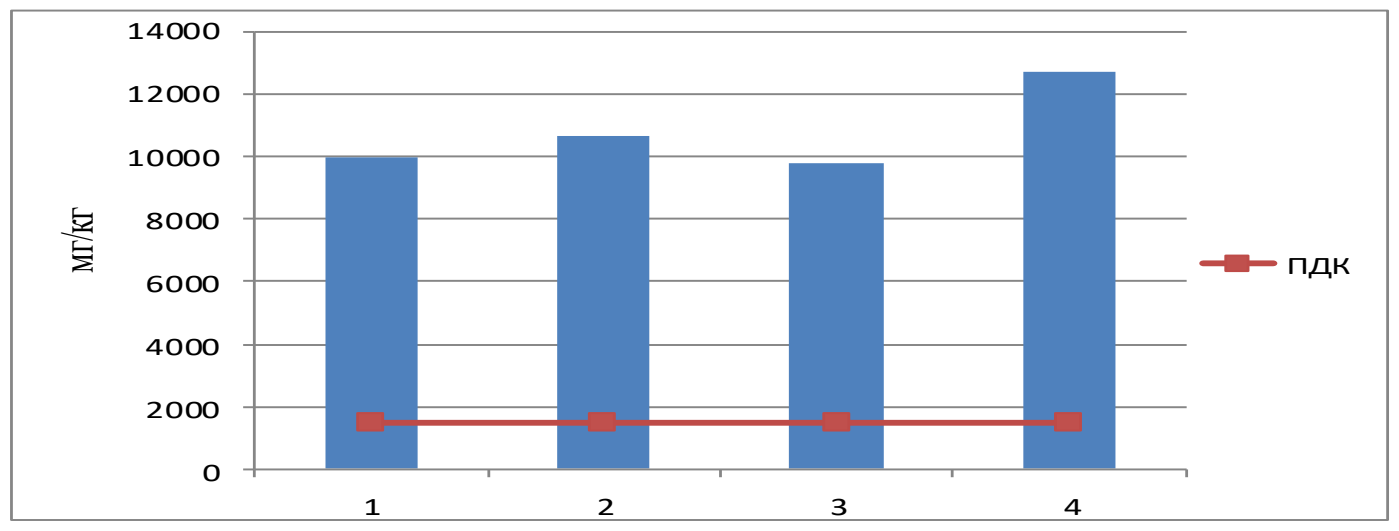

Рис. 1. Содержание марганца в почвах исследуемого района

Предельно допустимая концентрация валовой формы марганца составляет 1500 мг/кг [8]. Надо отметить, что во всех точках исследования содержание изучаемого элемента в почвах превышает предельно допустимую концентрацию от 6 до 8 раз. В районе отсутствует промышленные зоны, однако имеется месторождения марганцевых руд, что может быть и причиной высокого накопления марганца в почвах д. Кирдасово Абзелиловского района Республики Башкортостан.

\section{Список литературы:}

1. Агроэкологическая характеристика почвенно-растительного покрова Абзелиловского района Башкортостана. М., 1993.

2. Алексеев Ю.В. Тяжелые металлы в почвах и растениях. Л.: Агропромиздат, 1987.

3. Власюк П.А. Биологические элементы в жизнедеятельности растений. Киев: Наука, 1969. 516 c. 
бі 4. Гирфанов В.К., Ряховская Н.Н. Микроэлементы в почвах Башкирии и эффективности удобрений. М.: Наука, 1975. 171 c.

5. ГОСТ 17.4.3.01-83. Общие требования к отбору проб (СГ СЭВ 3347-82). М., 1983. 44 c.

6. Добровольский В.В. Основы биогеохимии. М.: Академия, 2003. 397 с.

7. А. Кабата-Пендиас, Х. Пендиас, «Микроэлементы в почвах и растениях» // М.: Мир, 1989. 439 с.

8. Методические указания по оценки степени опасности загрязнения почвы химическими веществами.

М.: Колос, 1987. 64c.

(C) 2015, Ягафарова Г.А., Кужина Г.Ш.

Содержание марганца в почвах д. Кирдасово

Абзелиловского района Республики Башкортостан
(C) 2015, Yagafarova G.A., Gugina G.Sh.

Manganese content in the ground was carried out in the Republic of Bashkortostan, in the village of Abzelilovsky region 


\title{
Дарбинян А.А., Дорофеева В.П., Копылович М.В., Мельникова С.Л., Токарева И.Е. Клинический случай заворота желудка у собаки
}

\author{
Darbinyan A.A., Dorofeeva V.P., Kopilovich M.V., \\ Melnikova S.L., Tokareva I.E. \\ Clinical case of twisting of the stomach in dogs
}

Острое расширение и заворот желудка переполнение желудка газами и жидкостью, сопровождающееся его вращением по брыжеечной оси. Это заболевание имеет многофакторную этиологию, но во всех случаях непосредственным условием является дисфункция сфинктера между пищеводом и желудком и обструкция оттока содержимого желудка через превратник. Гастропексия является частью хирургического лечения расширения и заворота желудка у собак. Если гастропексия не выполняется, то количество рецидивов заворота желудка достигает 80\%

Ключевые слова: заворот желудка, этиология, противошоковая терапия, гастропексия

\section{Дарбинян Адуник Артемович}

Кандидат ветеринарных наук, доцент Омский государственный аграрный университет им. П.А. Столыпина

2. Омск, ул. Орджоникидзе, 47

\section{Дорофеева Вера Павловна}

Кандидат ветеринарных наук, доцент

Омский государственный аграрный университет им. П.А. Столыпина

2. Омск, ул. Орджоникидзе, 47

\section{Копылович Марина Владимировна}

Кандидат ветеринарных наук, доцент

Омский государственный аграрный университет им. П.А. Столыпина

2. Омск, ул. Орджоникидзе, 47
Acute gastric extension - volvulus (GDV) is a hyperextension of the stomach with gas, liquid or scar in conjunction with the rotation of the stomach on its mesenteric axis. This disease has a multifactorial etiology. Gastric dilatation volvulus in dogs is likely caused by a multitude of factors, but in all cases the immediate prerequisite is a dysfunction of the sphincter between the esophagus and stomach and an obstruction of outflow through the pylorus. Gastropexy is part of the surgical treatment of gastric dilatation volvulus (GDV) in dogs. If not satisfied, the recurrence rate is $80 \%$ of GDV

Key words: gastric volvulus, etiology, antishock therapy, gastropexy

\section{Darbinyan Adhunik Artemovich}

Candidate of Veterinary Sciences, Associate Professor Omsk state agrarian university named P.A. Stolypin Omsk, Ordzhonikidze st., 47

\section{Dorofeeva Vera Pavlovna}

Candidate of Veterinary Sciences, Associate Professor Omsk state agrarian university named P.A. Stolypin Omsk, Ordzhonikidze st., 47

\section{Kopilovich Marina Vladimirovna}

Candidate of Veterinary Sciences, Associate Professor Omsk state agrarian university named P.A. Stolypin Omsk, Ordzhonikidze st., 47 


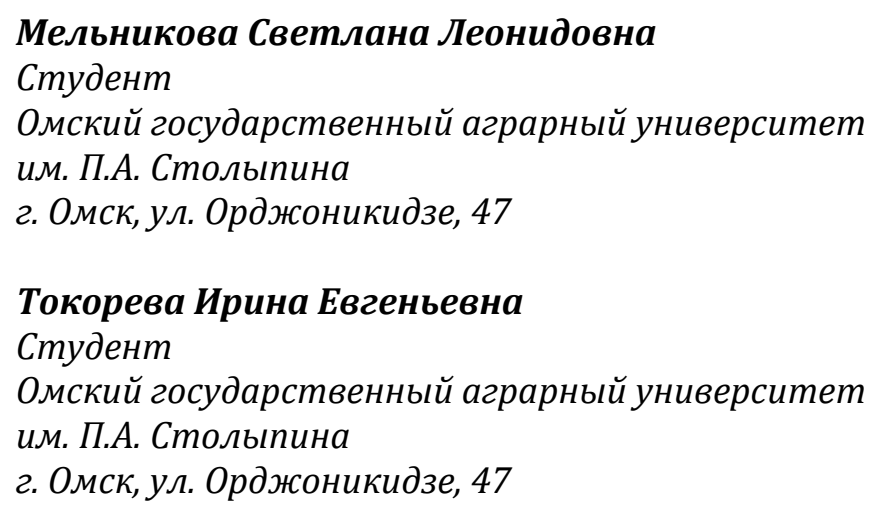

Melnikova Svetlana Leonidovna

Student

Omsk state agrarian university named P.A. Stolypin Omsk, Ordzhonikidze st., 47

\section{Tokoreva Irina Evgenievna}

Student

Omsk state agrarian university named P.A. Stolypin Omsk, Ordzhonikidze st., 47

Курируемое животное - собака, породы среднеазиатская овчарка, 12 лет, вес - 70 кг.

Со слов владельца животного, было выявлено следующее: во второй половине дня у собаки резко ухудшилось общее состояние, отмечалось угнетение, отказ от корма и воды, хрипы.

В результате клинического исследования животного установили: наличие гипертермии - 41,0оС (норма - 37,5 - 39,0 оС), тахикардию - ЧСС -140 (норма - 70 - 120/мин), одышку - ЧДД- 10 (норма - 14 - 24/мин), а также следующую клиническую картину: угнетенное состояние, опущенная голова, обильная саливация, шаткая походка, тяжелое дыхание, сильные хрипы, дыхание со стонами, анемичные видимые слизистые оболочки, синий язык, учащенное сердцебиение, слабый пульс, увеличенный объем живота, болезненная и напряженная брюшная стенка. При рентгенологическом исследовании было обнаружено увеличение границ желудка (рис.1).

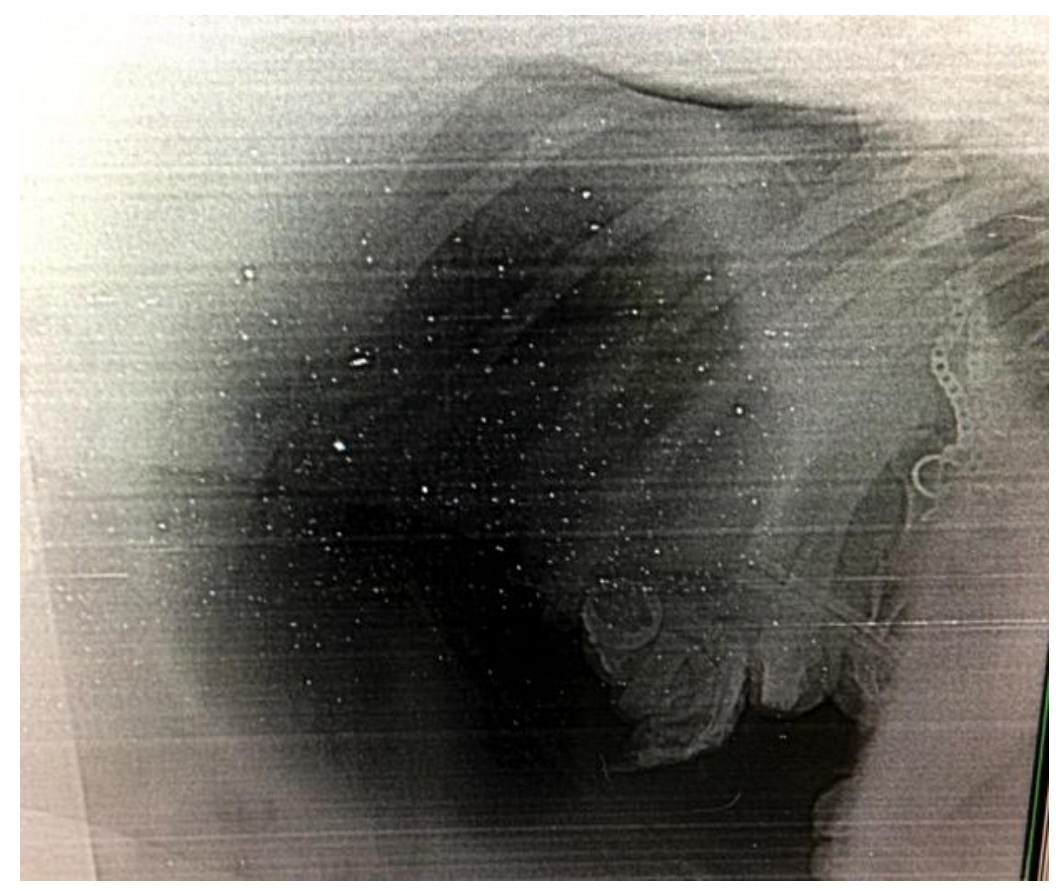

Рис. 1. Рентаенологическое исследование. Увеличение границ желудка

Было произведено ультразвуковое исследование брюшной полости, в результате которого было обнаружено скопление газов в тонком отделе кишеч- 
ника, скопление жидкости в брюшной полости, увеличение селезенки (рис. 2). По результатам гематологическое исследование крови было установлено следующее: нейтрофильный лейкоцитоз, гемоглобинопения, эритроцитпения, повышение скорости оседания эритроцитов.

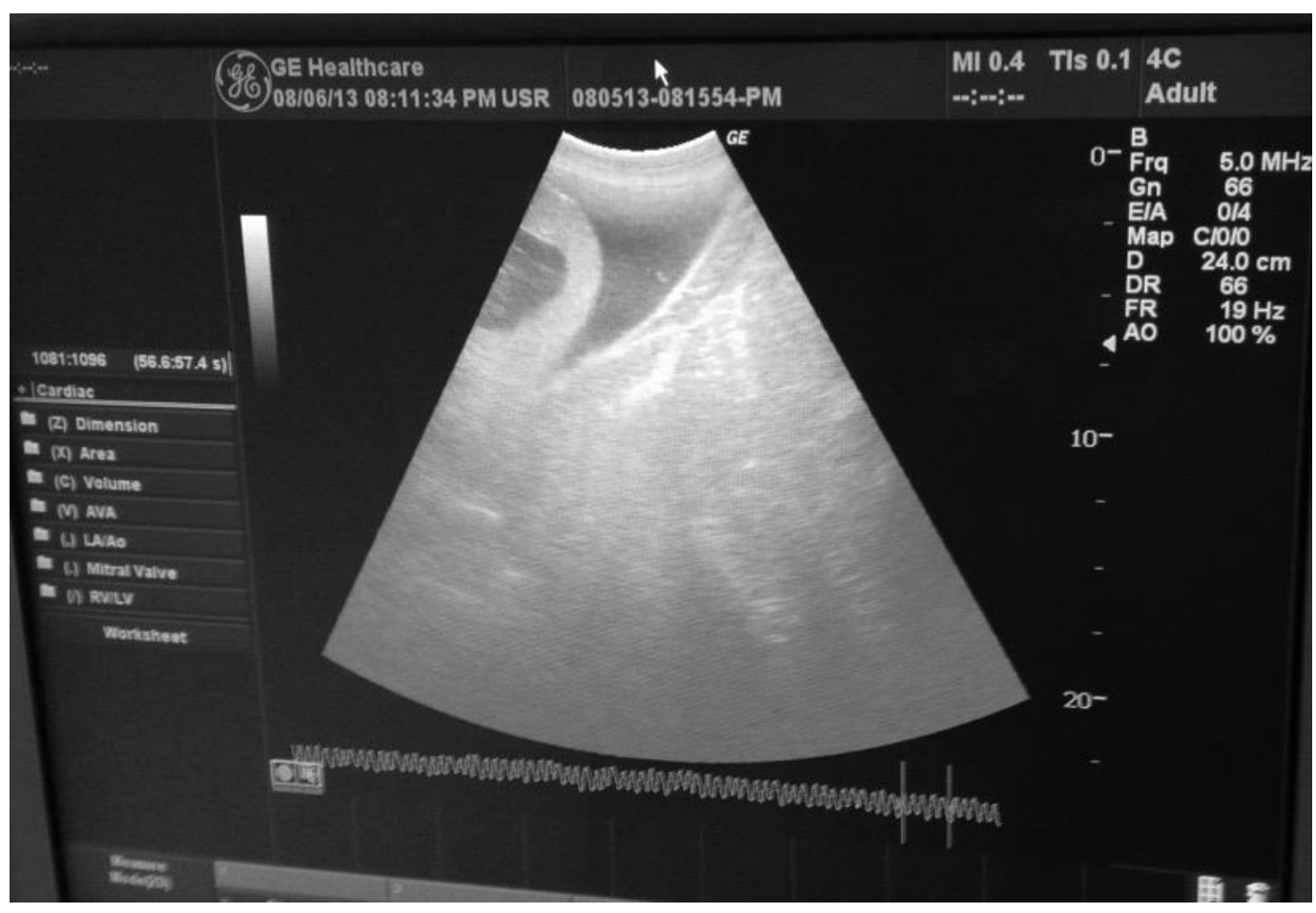

Рис. 2. Ультразвуковое исследование. Обнаружено скопление жидкости в брюшной полости

На основании анамнеза, клинических признаков, результатов рентгенологического и ультразвукового исследований был поставлен диагноз расширение и заворот желудка. Заворот желудка у собак - заболевание, которое развивается вследствие механической непроходимости или рефлекторного спазма кардия и пилоруса желудка с последующим накоплением в нем газов, смещением его по продольной или поперечной оси, спленомегалии, нарушению циркуляции крови в большом круге кровообращения и развитием шокового состояния организма, приводящего к летальному исходу [2].

Заболевание имеет различную этиологию и предрасполагающие факторы развития. Так, у курируемого животного возникновению и дальнейшему развитию данной патологии способствовали следующие обстоятельства:

Размеры и порода собаки. Собака данной породы характеризуется глубокой грудной клеткой и подобранным животом. Массивность собаки и рыхлое телосложение предопределяют слабость и растяжение связок, не способных удержать переполненный желудок в правильном положении, увеличивая риск развития заворота желудка.

Возраст собаки. Данному заболеванию в большей степени подвержены взрослые или пожилые собаки.

Несбалансированный тип питания и неправильный режим кормления послужили возможными причинами развития заболевания. Кормление объе- 
мистыми кормами (геркулесовая, перловая, пшенная каши, недоброкачественные продукты) предрасполагает к данной патологии вследствие высокой бродильной активности, способствующей ослаблению сократительной способности желудка, приводящей к перерастяжению и гиперплазии стенок желудка [3].

Расширение и заворот желудка у собак - заболевание опасное для жизни, при котором необходимо срочное проведение хирургической операции - гастропексии.

Перед операцией животному был дан общий наркоз с использованием Золетила и Ксилазина в общепринятых дозах для данного вида животного. Далее проведена интенсивная оксигенотерапия с искусственной вентиляцией легких. Были использованы следующие приборы и инструменты: большой операционный хирургический набор, электрокоагулятор, стерильный шелк №4 и №6, кетгут №4, другой инструментарий.

Перед подготовкой операционного поля область живота собаки была обработана с применением хозяйственного мыла, шерсть была сбрита и удалена с помощью щетки. Для дезинфекции операционного поля применялась следующая методика: обработка операционного поля 5\% спиртовым раствором йода, 70\% спиртом, ограничение операционными стерильными простынями, зафиксированными с помощью кожебельевых цапок. Руки хирурга и ассистента были обработаны 70\% спиртом и 5\% спиртовым раствором йода, надеты стерильные перчатки.

Оперативный доступ к желудку осуществлялся путем лапаротомии. Рассекли послойно кожу, подкожную клетчатку, наружную и внутреннюю косые брюшные мышцы, поперечную мышцу живота с поперечной фасцией, брюшину. По большой кривизне желудка в пилорической части сделали надрез на серозной оболочке длиной 4 см, аналогичный надрез сделали на брюшной стенке. Преддверие пилоруса захватили влажными компрессами и, не поворачивая, переместили к переднему углу разреза брюшной стенки, сближая надрезы на желудке и брюшине. На брюшину, поперечную фасцию и влагалище прямой мышцы живота в краниальной части лапаротомной раны наложили шов (медленно рассасывающийся), захватывающий на протяжении 4 - 5 см стенку желудка в зоне, не насыщенной кровеносными сосудами, а также серозную и мышечную оболочку с наименьшим натяжением. Шов обработали спреем, содержащий террамицин [1].

С целью оказания лечебной помощи после операции животному была проведена противошоковая терапия, включающая борьбу с болевым шоком, сердечно-сосудистой недостаточностью, дегидратацией, гипоксией и токсемией:

1. Физиологический раствор 3000 мл, в \в.

2. Раствор бикарбоната натрия 50 мл, в $\backslash$ в.

3. Маннитол 50 мл, в $\backslash$ в.

4. Преднизолон 3 мл, п\к.

5. Но-шпа 2 мл + анальгин 2 мл, в \м.

6. Ацилок 2 мл, сульфокамфокаин 2 мл. 
7. Атропин 1 мл + димедрол 2 мл.

Интенсивная терапия в послеоперационном периоде была направлена на коррекцию тяжелых изменений гомеостаза, лечение и профилактику послеоперационных осложнений и включала следующую схему применения лекарственных средств: инфузионное введение 5\% раствора глюкозы, физиологического раствора, бикарбоната натрия; анальгезирующая терапия, применение диуретиков; использование глюкокортикоидов; антибактериальная терапия антибиотиками широкого спектра действия (цефазолин, цефтриаксон, амоксициллин и др.); проведение симптоматической и витаминотерапии, физиотерапевтических процедур (массаж грудной клетки, конечностей, переворачивание животного с бока на бок и т.д.). Швы были сняты через 14 дней. Исход болезни - благоприятный.

Заворот и расширение желудка у собак - это острая хирургическая патология, требующая четкого выполнения оперативного вмешательства в первые часы с начала заболевания. С целью профилактики данного заболевания собакам средних и крупных пород старше пяти лет рекомендуется концентратный тип кормления и регулярные обследования у ветеринарных врачей для выявления субклинически протекающих заболеваний органов пищеварения.

\section{Список литературы:}

1. Шебищ Х., Брасс В. Оперативная хирургия собак и кошек. М.: Аквариум-Принт, 2012. 512 с.

2. Тимофеев С.В., Позябин С.В., Бахтионов В.А., Филиппов Ю.И. Хирургия желудка и селезенки у собак. М.: Зоомедлит, 2009. 107 с.

3. Ниманд Ханс Г., Сутер Петер Ф. Болезни собак. Практическое руководство для ветеринарных врачей (организация ветеринарной клиники, обследование, диагностика заболеваний, лечение). М.: АквариумПринт, 2011. 816 c.

(C) 2015, Дарбинян А.А., Дорофеева В.П., Копылович М.В., Мельникова С.Л., Токарева И.Е. Клинический случай заворота желудка у собаки
(C) 2015, Darbinyan A.A., Dorofeeva V.P., Kopilovich M.V., Melnikova S.L., Tokareva I.E. Clinical case of twisting of the stomach in dogs 


\title{
Дорофеева В.П., Копылович М.В., Мельникова С.Л. Ожирение у собак: факторы риска, диагностика и диетотерапия
}

\author{
Dorofeeva V.P., Kopilovich M.V., Melnikova S.L. \\ Obesity in dogs: risk factors, diagnosis and diet therapy
}

Изучение степени влияния диетического кормления на процесс снижения веса при диагнозе ожирение легло в основу нашего исследования, для участия в котором было отобрано 6 собак с диагнозом ожирение. В результате проведенных исследований у животных были обнаружены патологии сердечно-сосудистой, пищеварительной систем, а также наличие эндокринопатии и поражение опорно-двигательного аппарата. Животным была разработана индивидуальная программа снижения веса. Собаки первой группы получали разработанный низкокалорийный, сбалансированный рацион. Собакам второй группы были предоставлены готовые диетические корма разных торговых марок, суточное потребление которых было установлено, согласно индивидуальной энергетической потребности собак. У собак с индивидуальной диетической программой наблюдалась неоднозначная динамика снижения веса с отрицательными и положительными сдвигами графика. Усобак, потребляющих специальные диетические корма, было выявлено постепенное, умеренное снижение веса

Ключевые слова: ожирение, диетотерапия, программа снижения веса

\section{Дорофеева Вера Павловна}

Кандидат ветеринарных наук, доцент Омский государственный аграрный университет им. П. А. Столыпина

г. Омск, ул. Орджоникидзе, 47

\author{
Копылович Марина Владимировна \\ Кандидат ветеринарных наук, доцент \\ Омский государственный аграрный университет \\ им. П. А. Столыпина \\ г. Омск, ул. Орджоникидзе, 47
}

A study of the extent of the influence of dietary feeding the weight loss process when the diagnosis of obesity is the basis of our research, to participate in which 6 were selected dogs with a diagnosis of obesity. In studies in animals were discovered the pathology of the cardiovascular and digestive systems, as well as the presence of endocrinopathy and the defeat of the musculoskeletal system. Animals had a customized weight loss program. Dogs the first group received developed a lowcalorie, balanced diet. The dogs of the second group were provided with ready-made dietary feed different brands, the daily consumption of which has been set, according to the individual energy needs of dogs. In dogs with special dietary program was ambiguous dynamics of weight loss with negative and positive shifts of the graph. In dogs consuming special diet food, revealed a gradual, modest weight reduction

Key words: obesity, diet, weight loss program

\section{Dorofeeva Vera Pavlovna}

Candidate of Veterinary Sciences, Associate Professor Omsk state agrarian university named P.A. Stolypin Omsk, Ordzhonikidze st., 47

\section{Kopilovich Marina Vladimirovna}

Candidate of Veterinary Sciences, Associate Professor Omsk state agrarian university named P.A. Stolypin Omsk, Ordzhonikidze st., 47 


\section{Мельникова Светлана Леонидовна}

Студент

Омский государственный аграрный университет им. П. А. Столыпина

2. Омск, ул. Орджоникидзе, 47
Melnikova Svetlana Leonidovna

Student

Omsk state agrarian university named P.A. Stolypin

Omsk, Ordzhonikidze st., 47

Неблагоприятные реакции на пищевые продукты у животных, в том числе и ожирение, протекают с разнообразными клиническими признаками и характеризуются сложностью диагностических процедур. Под ожирением обычно понимают избыточное отложение жировой ткани в подкожной клетчатке и других тканях организма в совокупности с нарушением обмена веществ, если животное получает питательных веществ больше, чем расходует в процессе жизнедеятельности. Если вес собаки превышает нормальный более чем на 10\%, то масса тела считается избыточной, и возникает возможность развития ожирения. Положительный энергетический баланс зачастую является следствием поедания животным большего, чем необходимо, количества корма, снижения физической активности и скорости обмена веществ.

Ожирение влечёт за собой клинические последствия, отрицательно влияет на продолжительность жизни и ведет к развитию заболеваний внутренних органов. Повышается риск развития сахарного диабета, заболеваний сердечной сосудистой системы, опорно-двигательного аппарата, оказывается негативное воздействие на работу иммунной и репродуктивной системы, увеличивается непереносимость физических нагрузок и жары, повышаются хирургические и анестезиологические риски [2].

Факторы, предрасполагающие к набору лишнего веса и ожирения, многочисленны. Среди них хотелось выделить генетический фактор, возраст, половую и породную предрасположенность, последствия после проведения кастрации, тип питания животного. Набору веса способствуют обработки животного прогестином, эндокринопатии, гиперадренокортицизм и употребление определенных групп лекарственных препаратов.

Визуально распознать ожирение не составляет особого труда. Для определения степени ожирения используют различные методики: сопоставление параметров тела со стандартом породы; балльная оценка упитанности; морфометрические промеры; расчет индекса массы тела; анализ биоэлектрического сопротивления; двухэнергетическая рентгеновская абсорбциметрия и др. [1].

Особым элементом программы снижения веса является диетотерапия. Именно изучение степени влияния диетического кормления на процесс снижения веса при диагнозе ожирение легло в основу нашего исследования.

Для участия в исследовании было отобрано 6 собак (2 группы, по три животных) с диагнозом ожирение. Животные были подвергнуты клиническому исследованию с помощью общих и специальных методов диагностики, таких, как внешний осмотр, исследование пищеварительной, сердечно-сосудистой, мочеполовой, дыхательной систем, а также ультразвуковое исследование, электрокардиография, лабораторная диагностика крови, мочи и кала. Особое внимание при постановке диагноза было уделено биохимическому исследова- 
нию крови, в ходе которого было выявлено следующее: у 100\% животных наблюдалось значительное повышение уровня таких показателей крови, как аспартатаминотрансфераза, аланинаминотрасфераза, холестерин, общий билирубин; у 50\% собак отмечалось увеличение уровня гаммаглутамилтрансферазы и альфа-амилазы в крови.

Для определения степени избыточной массы нами был рассчитан индекс относительного веса животного (ИОВ) путем деления настоящего веса на оптимальный вес животного. В результате проведенных исследований у всех животных были обнаружены патологии сердечно-сосудистой, пищеварительной систем, а также наличие эндокринопатии и поражение опорно-двигательного аппарата. После постановки диагноза животным было оказано соответствующее патогенетическое лечение, а также была разработана индивидуальная программа снижения веса, рассчитанная с учетом ограничения потребления 50 - 60\% текущей калорийности рациона. Краткосрочная цель программы заключалась в снижении веса и достижении идеальной степени упитанности, долгосрочная - в сохранении массы тела на нужном уровне после прекращения программы.

Собаки первой группы в качестве диетического питания получали разработанный низкокалорийный, сбалансированный по белкам, жирам, углеводам и энергетической ценности рацион:

Мопс, Вита, 3 года, сука, кастрированная. Вес - 10,4 кг (стандарт - 6,3 - 8,1 кг). Цель - 7,7 кг. Программа рассчитана на 16 - 18 недель (с учетом степени ограничения 50 - 60\%). ИОВ - 1,28.

Лабрадор, Ника, 6 лет, сука, некастрированная. Вес - 39,1 кг (стандарт 25 - 32 кг). Цель - 30,5 кг. Программа рассчитана на 14 - 15 недель (с учетом степени ограничения 50 - 60\%). ИОВ - 1,22

Такса, Бакс, 5 лет, кобель, некастрированный. Вес - 11,7 кг (норма 7,8 - 8,9 кг). Цель - 8,0 кг. Программа рассчитана на 20 - 22 недель (с учетом степени ограничения 50 - 60\%). ИОВ - 1,30.

Собакам второй группы были предоставлены готовые диетические корма разных торговых марок, суточное потребление которых было установлено, согласно индивидуальной энергетической потребности собаки.

Мопс, Дося, 4 г, сука, кастрированная. Вес - 10,7 кг (стандарт - 6,3 - 8,1 кг). Цель - 7,9 кг. Программа рассчитана на 16 - 18 недель (с учетом степени ограничения $50-60 \%)$. ИОВ - 1,36.

Ротвейлер, Дана, 6 лет, сука, некастрированная. Вес - 53,7 кг (стандарт 41,5 - 43 кг). Цель - 42 кг. Программа рассчитана на 14 - 16 недель (с учетом степени ограничения 50 - 60\%). ИОВ - 1,23.

Английский бульдог, Фунт, 6 лет, кобель, некастрированный. Вес - 33,2 кг (стандарт - 24 - 45 кг). Цель - 24 кг. Программа рассчитана на 17 - 19 недель (с учетом степени ограничения 50 - 60\%). ИОВ - 1,33.

Сравнивая темпы снижения веса собак двух групп, сделали следующие выводы: у собак с индивидуальной диетической программой наблюдалась неоднозначная динамика снижения веса с отрицательными и положительными сдвигами графика. Данный факт был связан с погрешностью в диете. 


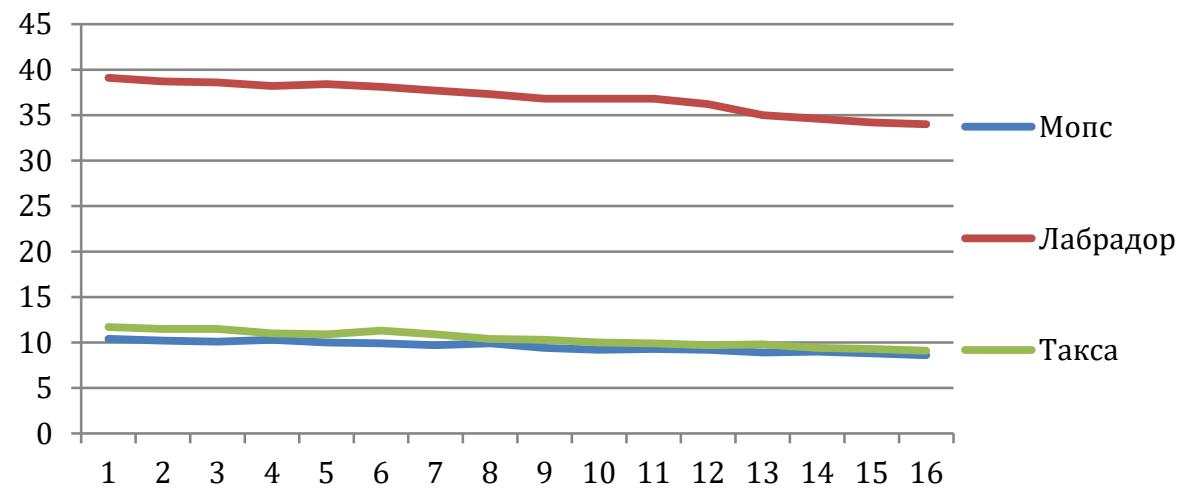

Рис. 1. Динамика снижения веса собак первой группы

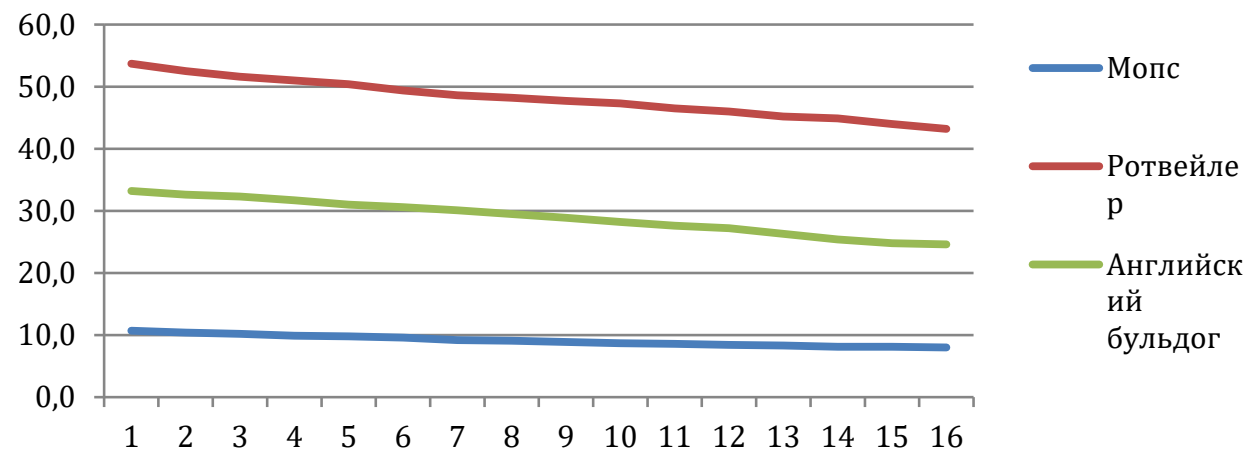

Pис. 2. Динамика снижения веса собак второй группы

У собак, потребляющих специальные диетические корма, было выявлено постепенное, умеренное снижение веса. За неделю вес собак этой группы снижался, в среднем, на 1,92\% от первоначального уровня, что находится в диапазоне оптимального снижения веса. У всех собак отмечалось повышение физической активности и общего эмоционального состояния. Благодаря оптимальному содержанию растворимой и нерастворимой фракций клетчатки, диетические корма позволяют значительно улучшить состояние животных в короткий промежуток времени, способствуя снижению веса и улучшая биохимические показатели крови (холестерин, альфа-амилаза).

\section{Список литературы:}

1. Анисимова Н.П. Физиологические показатели (показатели здоровья) собак и кошек. URL: vet-24.ru/publications/fiziologicheskie-pokazateli-pokazateli-zdorovya-sobak-i-koshek 2. Новикова И.В. Ожирение у мелких домашних животных.

URL: www.vethelp.ru/useful/1413.html

(C) 2015, Дорофеева В.П., Копылович М.В., Мельникова С.Л.

Ожирение у собак: факторы риска, диагностика и диетотерапия
(C) 2015, Dorofeeva V.P., Kopilovich M.V., Melnikova S.L.

Obesity in dogs: risk factors, diagnosis and diet therapy 


\title{
Лаврентьев Б.Ф. Повышение рентабельности пчеловодства в России за счет создания специализированных приборов
}

\author{
Lavrentev B.F. \\ Increased profitability of beekeeping in Russia \\ by creating specialized units
}

Рассматриваются вопросы состояния пчеловодства в нашей стране. Отмечается, что повышение рентабельности в пчеловодстве возможно только за счет создания приборов для пчеловодства таких как приборы для сбора пчелиного яда, приборов для приготовления «серебряной воды», приборов для диагностики состояния пчелосемей и других

Ключевые слова: пчелы, пчелиный яд, пчелосемья, мед, диагностика, рентабельность, ульи, «серебряная вода», серийное изготовление

\section{Лаврентьев Борис Федорович}

Кандидат технических наук, профессор

Поволжский государственный технологический университет

Респ. Марий Эл, г. Йошкар-Ола, пл. Ленина, 3
Discusses the state of beekeeping in our country. It is noted that the increase in profitability in beekeeping is possible only through the creation of instruments for beekeeping such as devices for the collection of bee venom, devices for making "silver water", devices for diagnostics of bee colonies and others

Key words: bees, bee venom, bee colonies, honey, diagnostics, profitability, hives, "silver water" serial production

\section{Lavrentev Boris Fedorovich}

Candidate of Engineering Sciences, Professor

Volga State University of Technology

Mari El, Yoshkar-Ola, square Lenin, 3

Введение. Пчеловодством в России занимались с древних времен. Однако в последнее время из-за низкой рентабельности и отсутствия программы развития оно не может конкурировать с зарубежными производителями пчелопродуктов. Следует помнить, что пчеловодство дает ценные питательные, диетические и лекарственные продукты. Основной из них - мед. Он содержит, кроме легкоусвояемых сахаров - глюкозы и фруктозы, до 50 различных веществ и соединений и с большим успехом используется при лечении и профилактике сердечной недостаточности, всякого рода истощений, некоторых заболеваний желудка.

Вторым по значению продуктом пчеловодства является воск. Он служит сырьем для более чем 80 отраслей народного хозяйства. Так, в медицине его вводят как компонент в мази и кремы; в электротехнической промышленности его включают в состав изолирующих материалов. Воск расходуют при изготовлении мастики для натирания полов, крема для обуви, красок, цветных карандашей и т.д. 
Издавна в медицине для лечения ряда заболеваний используют пчелиный яд. Из него приготавливают лекарственные мази, которые втирают в кожу, а в народной медицине используют укусы пчел. Пыльцу, собранную пчелами, применяют как естественный поливитаминный препарат, потому что в ней содержатся разнообразные витамины и питательные вещества, необходимые для роста и развития организма [1].

Целебные свойства имеет маточное молочко - сложный продукт, который пчелы вырабатывают в своих железах. Из него получают препарат «Апилак», используемый в медицине.

Доказано также лекарственное значение клейкого вещества - прополиса, который пчелы собирают с почек некоторых растений. Его также используют для приготовления мазей и лекарственных препаратов. Исключительно велика роль пчел в опылении сельскохозяйственных растений. Эти насекомые опыляют до 200 различных культур. Посещая цветки одного вида растений, пчелы переносят пыльцу с цветка на цветок (перекрестное опыление), в результате чего образуются полноценные завязи. Это значительно повышает урожайность.

Огромное внимание уделяется развитию пчеловодства во многих странах мира. Разработаны программы развития пчеловодства, которые повышают рентабельность пчеловодства повышают его конкурентность на международных рынках, снижают стоимость продуктов пчеловодства. Поэтому, если не повысить рентабельность в пчеловодстве, то после вступления России в ВТО пчеловодство в нашей стране ожидают большие трудности.

Как показывает опыт отечественного и зарубежного пчеловодства, выход из этого положения, т.е. повышение эффективности и получение достаточной прибыли, возможно обеспечить только при комплексном использовании пчелиных семей на производстве не только мёда, но и воска, пакетов пчёл, маток, биологически активной продукции (маточного молока, пыльцы, прополиса, пчелиного яда). Для получения сильных пчелосемей необходимо обеспечить пасеки высокоэффективными приборами для диагностики состояния пчел на различных этапах их развития, универсальными приборами для пчеловода, приборами для сбора пчелиного яда приборами для получения «серебряной воды», которая используется для питания пчел, дезинфекции ульев и борьбы с основными болезнями пчел.

Особое внимание следует уделить получению пчелиного яда. Пчелиный яд используется во многих лекарственных препаратах. В нашей стране пчелиный яд практически не собирается и все лекарства на основе яда приобретаются за границей [2].

Практика показала, что с одной пчелосемьи, помимо меда, можно за год получить: пчелиного яда (1 -3) гр., цветочной пыльцы до 6 кг, прополиса до 2 кг; маточного молочка до 500 гр. Что касается меда, то его количество, при использовании передвижных пасек, можно увеличить в 3-5 раз

Таким образом, используя все продукты пчеловодства, можно сделать пчеловодство достаточно доходной отраслью народного хозяйства. 
Целью настоящей работы является повышение рентабельности пчеловодства и повышение его конкурентоспособности на мировом рынке за счет создание приборов и методик для пчеловодства и проведение научных и экспериментальных исследований жизнеспособности и продуктивности пчелосемей при использовании различных режимов работы приборов, времени сезона, погодных условий, времени суток.

Кроме того, выполняемая работа позволит выполнить важные научные исследования и найти неизвестные закономерности в биологических экосистемах, что очень важно для науки.

В Поволжском государственном технологическом университете (ПГТУ) работы по созданию приборов для пчеловодства ведутся в течение нескольких последних лет.

В предлагаемых приборах используется целый ряд технических решений, которые позволяют создавать приборы с высокими техническими характеристиками, а именно: высокой эффективностью, небольшой стоимостью и хорошими эксплуатационными характеристиками. Приборы для приготовления «серебряной воды» для нужд пчеловодства и приборы для диагностирования состояния пчелиных семей позволяют оздоровить пчелиные семьи, повысить их продуктивность, снизить процент гибели пчёл особенно при их зимовке и решить многие другие.

Ниже приведен обзор работ по созданию приборов для пчеловодства, проводимый в ПГТУ в последние годы.

Прибор для получения пчелиного яда. В настоящее время в ПГТУ создан промышленный образец прибора для получения пчелиного яда, который выпущен опытной партией и успешно испытан на пасеках. В приборе использованы новые технические решения, которые защищены патентами $[3,4]$. Прибор для получения пчелиного яда предназначен для сбора пчелиного яда на коллективных и индивидуальных пасеках [5].

Основные требования к прибору:

- прибор должен работать в полевых условиях (на пасеках),

- диапазон рабочей температуры, ............................-5 $\div 40$ 으

- влажность при $\mathrm{t}=20^{\circ} \mathrm{C}$, $80 \%$;

- автономность работы, час. не менее 48;

На основании полученной информации и испытаний макета прибора были сформулированы его основные технические характеристики.

Основные характеристики прибора:

- длительность импульса воздействия, с

- длительность пауз, с. $.0,5 \div 4$

- амплитуда выходных сигналов, В ... $0-50$

- время работы, ч $1,5-3$

- несущая частота, кГц $1-2$

- максимальный выходной ток, А $0 \div 0,2$

- автономность работы, час, не менее 48;

Питание прибора производится от аккумулятора. 
Отличительной особенностью прибора является введение режима автоматического изменения программы работы с изменением параметров выходных параметров. Этот режим позволяет исключить привыкание пчел к раздражающим воздействиям и тем самым повысить производительность процесса получения яда. Прибор имеет защиту от короткого замыкания в линиях связи или в ядоприемниках, что существенно повышает его эксплуатационные характеристики. Органами управления, выведенными на переднюю панель прибора, можно установить амплитуду выходных сигналов в пределах 20 - 70 В, время сеанса и режим работы. Достоинством прибора является то, что нет необходимости отдельно устанавливать параметры выходных сигналов, так как это автоматически выполняется по программе. В приборе предусматривается внутренний аккумулятор. Кроме того, прибор может работать от внешнего аккумулятора, например от автомобильного. Прибор прост в эксплуатации, на него разработана эксплуатационная и техническая документация: описание, инструкция по эксплуатации, формуляр.

В настоящее время разрабатывается система сбора пчелиного яда, включающая в себя устройство сбора пчелиного яда, транспортное устройство для проводных линий связи и ядоприемники, а также техническая документация для серийного изготовления на малом предприятии. Проведенный информационный поиск показал, что на сегодняшний день медицинские препараты на основе пчелиного яда, в основном, приобретаются за рубежом.

Приборы для получения «серебряной» воды

Применение «серебряной» воды в пчеловодстве позволит значительно оздоровить пчелиные семьи. «Серебряная» вода малой концентрации используется для питания пчел, а, следовательно, позволит получить большую отдачу от каждой пчелосемьи. Особенностью таких приборов для пчеловодства является необходимость получения серебряной воды различной концентрации в условиях пасек. Концентрация ионов серебра должна составлять: для поения пчел - 05-1,2 мкг/л., для приготовления сиропа - 3,5-10 мкг/л, для промывки ульев и дезинфекции - 18- 60 мкг/л и для лечения варрикоза - 60 - 80 мкг/л. Второй особенностью таких приборов является его работа в полевых условиях, что требует высокой надежности прибора, хороших эксплуатационных характеристик, удобства эксплуатации и защиту от влаги и механических воздействий среды, а также удобство переноски и транспортировки.

В настоящее время существует большое количество установок для обработки воды ионами серебра (Патенты RU 98102163 A, RU 93057525 A, RU 98105315 A, RU 2143406 A, RU 2143406 C1 и другие). Такие установки предназначены для получения большого количества «серебряной» воды, являются стационарными и отличаются сложностью и высокой стоимостью, неудобством эксплуатации и неравномерностью распределения ионов серебра в воде.

Существует большое количество бытовых автономных ионизаторов воды, например «Пингвин», «Дельфин», «Сильва», «Георгий», «Невотон». Эти приборы применяются в домашних условиях и не могут обеспечить необходимую концентрацию ионов серебра в воде. Они также малоэффективны при работе в условиях пасек. 
В Поволжском государственном технологическом университете в 2013 году создан прибор для получения «серебряной» воды с концентрацией серебра до 100 мг/л, в состав которого введен стабилизатор тока на базе операционном усилители и таймер времени ионизации [6].Наличие стабилизатора тока и таймера позволило значительно повысить точность концентрации серебра в воде и автоматически отключать процесс ионизации после достижения заданной концентрации ионной серебра в воде.

В 2014 году разработан новый прибор для получения «серебряной» вода, в состав которого введен стабилизатор тока и счетчик количества электричества [7]. Благодаря счетчику количества электричества значительно снизилась погрешность задаваемой концентрации ионов серебра от внешних факторов, в том числе от параметров внешней среды, состава воды, состояния электродов и т.д. и одновременно улучшились эксплуатационные показатели.

В настоящее время создается установка для непрерывного получения «серебряной» воды заданной концентрации, в состав которой входит камера предварительной очистки воды, проточная камера ионизации воды ионами серебра с выходным вентилем и блок формирования тока ионизации. Управление величиной тока ионизации происходит с помощью специального вычислительного устройства, на вход которого поступают сигналы с датчиков расхода воды (выходного вентиля), с датчика параметров воды с датчиков количества электричества с датчиков заданной концентрации воды ионами серебра и других датчиков. Установка может быть использована в крупных хозяйствах и обеспечивать возможность получения больших объемов воды с равномерной концентрацией ионов серебра в воде, что выгодно отличает её от существующих установок.

Приборы для диагностирования состояния пчелосемей. Одной из важнейших задач пчеловодства является периодическое диагностирование состояния пчелосемей. Это особенно важно в период зимнего хранения, в период роения и в период интенсивного сбора меда. Состояние пчелосемей можно определить по частотной характеристике звуков, издаваемых пчелами. Результаты многочисленных экспериментов с пчелами свидетельствуют о том, что частотная характеристика звукового фона улья определяет функциональное состояние пчел.

Специальные сигналы и звуки, возникающие в процессе жизнедеятельности пчел, отражают их состояние. На этом основаны методы акустической диагностики. Наиболее четким показателем, характеризующим уровень активности пчел, является соотношение интенсивности спектральных составляющих в диапазоне 200-400 Гц. При снижении активности пчелосемей (роение, болезни, отсутствие матки и т.д.) максимальный спектр частот смещается в область 210-250 Гц.

По спектру можно определить микроклимат в улье, в том числе перегрев или высокую концентрацию углекислого газа, а также прогнозировать состояние пчелосемей в зимний период. Для выявления семей, зараженных варрикозом достаточно определить частотное положение пика интенсивности звука в диапазоне 300-400 Гц. 
Одной из важнейших задач при проектировании приборов для диагностики состояния пчелосемей является разработка компьютерной программы по спектральному анализу звукового фона пчелиной семьи - это основа всего прибора и основная трудность при его создании.

Работы по созданию малогабаритных диагностических приборов для пчеловодства ведутся в ПГТУ в течение последних лет.

В 2015 году планируется с использованием разработанной в 2014 году системы сбора пчелиного яда провести экспериментальные исследования по сбору пчелиного яда, нахождения оптимальных режимов работы приборов и исследования влияния, электрических полей на продуктивность пчел. Предполагается исследовать состояния пчелосемей на различных этапах их развития при сборе пчелиного яда с использованием различных режимов работы прибора, времени сезона, погодных условий, времени суток и т.д., продолжится работа по нахождению новых источников раздражения пчел (звуковых, световых, вибрационных, СВЧ, микрофонных), которые могут повысить производительность системы, упростить аппаратуру и снизить её стоимость. Если результаты будут положительны, будут поданы соответствующие заявки на патенты РФ и изготовлены макеты. Планируется выполнить теоретические расчеты концентрации ионов серебра в воде в зависимости от тока ионизации, положения электродов, состава воды, состояния воды, размеров камеры и наличия осаждения серебра на катоде , что не учитывается в существующих приборах .

В процессе выполнения настоящей работы планируется публикация ряда научных статей и коллективной монографии

\section{Список литературы:}

1. Третьяков Ю.Н., Пчелиный яд. Способы получения пчелиного яда. Приборы для получения пчелиного яда. СПб.: Диля. 2008. 112 с.

2. Лаврентьев Б.Ф., Лебедева А.А., Красильникова Э.М. Пчелиный яд. Получение. Стандартизация.

Применение // НАУ Ежемесячный научный журнал. № 3. 2014. Екатеринбург. C.120-122.

3. Лаврентьев Б.Ф. Устройство для сбора пчелиного яда. Патент РФ № 148852 U1 МКП А01К55/00.

Опубликовано 20.12.2014.

4. Лаврентьев Б.Ф., Петухов И.В., Белов Д.А. Устройство для сбора пчелиного яда. Патент РФ № 128962 U1 МКП А01К55/00 Опубликовано 20. 06.2013.

5. Лаврентьев Б.Ф., Бусыгин Г.В., Красильникова Э.М. Система сбора пчелиного яда «МУКШ 2» // Актуальные вопросы образования и науки. Тамбов: ЮКОМ. 2014. С. 90-93.

6. Лаврентьев Б.Ф., Федосеев В.И., Эмекин А.А. Прибор для получения серебряной воды. Патент РФ № 144849 U1 МПК С02F1/467. Опубликовано 10.09.2014.

7. Лаврентьев Б.Ф., Бусыгин Г.В., Бастраков Ю.А. Лебедева А.А. Прибор для получения серебряной воды. Патент РФ №143083 U1 МПК С02F1/467. Опубликовано 10.07.2014.

8. Хомутов А.Е., Гиноян Р.В., Петров В.А. Биологические основы получения пчелиного яда. Монография. M. 2014. 285 C.

\section{(C) 2015, Лаврентьев Б.Ф.}

Повышение рентабельности пчеловодства в России за счет создания специализированных приборов
(C) 2015, Lavrentev B.F. Increased profitability of beekeeping in Russia by creating specialized units 


\title{
Ховалыг Р.Б. Животноводство - приоритетное направление в сельском хозяйстве региона
}

\author{
Khovalyg R.B. \\ Livestock - priority to agriculture in the region
}

\section{Животноводство - ведущая отрасль сельского хозяйства в республике. В ведущей отрасли животноводства наблюдается устойчивый рост поголовья всех видов скота. В работе проанализированы тенденции развития животноводства в Республике Тыва, определены проблемы и перспективы развития отрасли животноводства до 2020 г.}

Ключевые слова: сельское хозяйство, животноводство, мясо-молочное скотоводство, овцеводство, козоводство, чабаны-тысячники, коневодство, государственная программа

\section{Ховалыг Раиса Белек \\ Старший преподаватель \\ Тувинский государственный университет г. Кызыл ул. Ленина, 36}

\begin{abstract}
Livestock - leading branch of agriculture in the country. In leading the livestock industry has seen a steady increase in the number of all types of livestock. This paper analyzes the trends in the development of animal husbandry in the Republic of Tyva, identified the problems and prospects of development of the livestock industry up to 2020
\end{abstract}

Key words: agriculture, livestock, meat and dairy cattle, sheep, goat, shepherds-thousanders, horse breeding, a state program

\author{
Khovalyg Raisa Belek \\ Senior Lecturer \\ Tuvinian State University \\ Kyzyl, Lenina st., 36
}

Сельское хозяйство является одним из важнейших секторов экономики республики. В сельской местности проживают сегодня 142,4 тысячи человек, или $46 \%$ населения республики. В сельскохозяйственном производстве во всех категориях хозяйств работают более 25 тысяч человек, или $24 \%$ общей численности работающих в региональной экономике. Высокий удельный вес сельского населения в общей численности населения республики обусловил приоритетность в социально-экономической политике комплексного и устойчивого развития сельских территорий, их инфраструктурного обустройства.

Животноводство - ведущая отрасль сельского хозяйства в республике. Животноводство в Республике Тыва является исторически сложившимся укладом жизни, традиционным видом хозяйствования и находится под особой защитой государства [1].

Сельскохозяйственным производством в республике занимается 47632 предприятия всех форм собственности, из них - 36 сельхозпредприятий, 596 КФХ и СПК и 47 тыс. личных подсобных хозяйств населения. 
Общая земельная площадь, используемая сельхозтоваропроизводителями составляет 3371,5тыс. га, в том числе 2650,9 тыс. га сельскохозяйственных угодий. Особенностью пастбищных угодий республики является возможность использования значительной их части в течение круглого года для выпаса мелкого и крупного рогатого скота [3].

Наличие в республике различных природно-климатических зон с разнообразными возможностями тех или иных отраслей придает необходимость разработки научно-обоснованной системы ведения животноводства. Система ведения животноводства региона представляет собой комплексную программу мероприятий и рекомендаций, направленных на ускоренное и стабильное развитие отраслей, более полное использование трудовых, материальных и природных ресурсов. Система животноводства базируется на широком использовании результатов исследований, разработок и новых технологий в животноводстве АПК региона [2].

В последние годы отмечаются тенденции увеличения численности поголовья скота, производства продукции животноводства, преодолены кризисные явления и закрепились показатели положительной динамики.

В ведущей отрасли - животноводстве наблюдается устойчивый рост поголовья основных видов скота.

Таблица 1. Поголовье скота и птицы в хозяйствах всех категорий на 1 января тыс. голов

\begin{tabular}{|c|c|c|c|c|c|c|c|c|c|c|c|c|}
\hline \multirow{3}{*}{$\begin{array}{l}\text { Виды } \\
\text { скота }\end{array}$} & \multirow{2}{*}{\multicolumn{3}{|c|}{$\begin{array}{c}\text { Хозяйства всех кате- } \\
\text { горий }\end{array}$}} & \multicolumn{9}{|c|}{ В том числе } \\
\hline & & & & \multicolumn{3}{|c|}{$\begin{array}{c}\text { Сельскохозяй- } \\
\text { ственн. }\end{array}$} & \multicolumn{3}{|c|}{$\begin{array}{c}\text { Хозяйства населе- } \\
\text { ния }\end{array}$} & \multicolumn{3}{|c|}{$\begin{array}{c}\text { Крестьянские } \\
\text { ферм. }\end{array}$} \\
\hline & 2013 & 2014 & $\begin{array}{l}2013 \\
\text { в \% к } \\
2014\end{array}$ & 2013 & 2014 & $\begin{array}{c}2013 \text { в } \\
\% \text { к } \\
2014\end{array}$ & 2013 & 2014 & $\begin{array}{c}2013 \\
\text { В \% к } \\
2014\end{array}$ & 2013 & 2014 & $\begin{array}{l}2013 \\
\text { В \% к } \\
2014\end{array}$ \\
\hline $\begin{array}{l}\text { Крупный } \\
\text { рог. скот }\end{array}$ & 150,5 & 150,7 & 100,1 & 17,0 & 16,9 & 99,4 & 111,9 & 116,7 & 98,0 & 14,3 & 17,0 & 118,9 \\
\hline $\begin{array}{l}\text { В т. ч. ко- } \\
\text { ровы }\end{array}$ & 65,5 & 66,0 & 100,8 & 7,9 & 8,0 & 101,3 & 50,9 & 50,0 & 98,2 & 6,6 & 8,1 & 122,7 \\
\hline Свиньи & 19,9 & 17,8 & 89,4 & 1,2 & 1,2 & 100 & 17,4 & 14,9 & 85,6 & 1,3 & 1,7 & 130,8 \\
\hline $\begin{array}{c}\text { Овцы и } \\
\text { козы }\end{array}$ & 1134,5 & 1154,6 & 101,8 & 339,9 & 328,4 & 98,4 & 646,1 & 641,8 & 99,3 & 154 & 184 & 119,3 \\
\hline $\begin{array}{l}\text { овцы - } \\
\text { всего }\end{array}$ & 741,9 & 756,0 & 101,9 & 236,8 & 235,2 & 99,3 & 405,0 & 401,3 & 99,1 & 100 & 119 & 119,4 \\
\hline $\begin{array}{c}\text { козы - } \\
\text { всего }\end{array}$ & 392,6 & 398,6 & 101,5 & 97,1 & 93,2 & 96,0 & 241,1 & 240,5 & 99,8 & 54,4 & 64,9 & 119,3 \\
\hline Лошади & 53,0 & 56,7 & 107,0 & 13,2 & 14,5 & 109,8 & 28,4 & 27,8 & 97,9 & 11,4 & 14,4 & 126,3 \\
\hline $\begin{array}{l}\text { Верблю- } \\
\text { ды, голов }\end{array}$ & 192 & 190 & 99,0 & 165 & 168 & 101,8 & 21 & 13 & 61,9 & 6 & 9 & 150,0 \\
\hline $\begin{array}{c}\text { Ослы, го- } \\
\text { лов }\end{array}$ & 5 & 5 & 100,0 & 5 & 5 & 100,0 & - & - & - & - & - & - \\
\hline $\begin{array}{c}\text { Северные } \\
\text { олени }\end{array}$ & 2,0 & 2,5 & 125,0 & 1,1 & 1,4 & 127,3 & 0,9 & 1,0 & 111,1 & - & - & - \\
\hline Птица & 15,6 & 13,8 & 88,5 & 0,1 & 0,05 & 50,0 & 15,1 & 13,4 & 88,7 & 0,4 & 0,3 & 75,0 \\
\hline
\end{tabular}


В крупных и средних сельскохозяйственных организациях на 1 января 2014 года поголовье овец и коз увеличилось по сравнению с 2013 г. на 1,8 \%, коров - на 0,8\%,лошадей на 7,0 \%. Значительное количество поголовья скота разных видов содержатся в хозяйствах населения [4].

Таблица 2. Производство основных видов продукции животноводства в хозяйствах всех категорий

\begin{tabular}{|l|c|c|c|c|}
\hline \multicolumn{1}{|c|}{ Продукция } & 2012 г. & 2013 г. & $\begin{array}{c}2013 \text { г в \% } \\
\text { к 2012 г. }\end{array}$ & $\begin{array}{c}\text { Справочно: } \\
2012 \text { г. в \% к 2011г. }\end{array}$ \\
\hline $\begin{array}{l}\text { Мясо (скот и птица на убой } \\
\text { в живом весе), тонн }\end{array}$ & 21571 & 21924,1 & 101,6 & 103,4 \\
\hline Молоко, тонн & 62083 & 62643,8 & 100,9 & 99,9 \\
\hline Яйцо, тыс. штук & 1941 & 2250,1 & 115,9 & 28,7 \\
\hline Шерсть, тонн & 1379 & 1425 & 103,3 & 100,5 \\
\hline
\end{tabular}

В крупных и средних сельскохозяйственных предприятиях в 2013 году по сравнению с 2012 годом увеличилось производство мяса, молока, яиц и шерсти. В 2012 г. по сравнению с 2011 г. производство мяса увеличилось на 3,4\% [8].

Таблица 3. Продукция сельского хозяйства по всем категориям хозяйств (в фактически действовавших ценах; миллионов рублей)

\begin{tabular}{|l|c|c|c|c|c|}
\hline \multicolumn{1}{|c|}{ Годы } & 2009 & 2010 & 2011 & 2012 & 2013 \\
\hline $\begin{array}{l}\text { Продукция сельского хозяйства в том } \\
\text { числе: }\end{array}$ & 4191,6 & 4426,5 & 4647,7 & 4808,0 & 5253,3 \\
\hline растениеводство & 971,5 & 1047,0 & 826,4 & 847,7 & 1051,4 \\
\hline животноводство & 3220,1 & 3379,4 & 3821,3 & 3960,3 & 4201,9 \\
\hline $\begin{array}{l}\text { Индекс физического объема, в \% к } \\
\text { предыдущему году }\end{array}$ & 102,6 & 94,7 & 106,9 & 95,9 & 101,4 \\
\hline
\end{tabular}

Как видно из таблицы, объем валовой продукции сельского хозяйства с каждым годом повышается. Валовая продукция в 2013 г. оценена на сумму 5253, 3 млн. рублей, из них 4201,9 млн. рублей приходится на продукцию животноводства [6].

Таблица 4. Структура продукции сельского хозяйства по всем категориям хозяйств (в фактически действовавших ценах; в процентах к итогу)

\begin{tabular}{|l|c|c|c|c|c|}
\hline \multicolumn{1}{|c|}{ Годы } & 2009 & 2010 & 2011 & 2012 & 2013 \\
\hline $\begin{array}{l}\text { Хозяйства всех категорий в том чис- } \\
\text { ле: }\end{array}$ & 100 & 100 & 100 & 100 & 100 \\
\hline сельскохозяйственные организации & 10,1 & 12,1 & 12,3 & 12,4 & 11,8 \\
\hline хозяйства населения & 83,5 & 83,3 & 80,5 & 81,0 & 81,7 \\
\hline крестьянские фермерские хозяйства & 6,4 & 4,6 & 7,2 & 6,6 & 6,5 \\
\hline
\end{tabular}


В структуре производства продукции сельского хозяйства в 2013 г. наибольший удельный вес имеют хозяйства населения, что составляет 81,7 \%. Сельскохозяйственные организации - 11,8 \%. Наименьшую долю в структуре производства продукции сельского хозяйства составляют крестьянские фермерские хозяйства - 6,5 \% [6].

От объема производства хозяйств населения зависит динамика развития всего сельского хозяйства. Следует заметить, что эффективное развитие производства сельскохозяйственной продукции в хозяйствах населения, прежде всего, выражало реакцию значительной части населения республики на возникшие экономические трудности, как средство выживания.

Личные подсобные хозяйства населения имеют большое значение, прежде всего, в обеспечении населения продовольствием. Спад производства в сельскохозяйственных организациях привел к значительному уменьшению рабочих мест на селе, увеличению числа людей, свободных от работы в коллективных организациях. На селе наступил период, когда для сельского населения личное подворье стало основным, а в большинстве случаев - единственным местом приложения труда и главным источником доходов сельского населения, следовательно, и его существования [7].

Республика Тыва является одной из перспективных зон Западной Сибири для развития специализированного мясного направления крупного рогатого скота. Мясное скотоводство должно получить значительное развитие в хозяйствах Южной и Западной зонах республики.

Основной массив молочного скота представлен симментальской породой. Животные этой породы имеют два направления продуктивности - молочное и молочно-мясное. К молочному типу скота отнесены помесные животные, полученные от скрещивания симменталов с молочными породами, молочномясному - чистопородные симменталы. Животные симментальской породы по продуктивным качествам, пластичности, акклиматизационным способностям выгодно отличаются от других пород, разводимых в республике, что и обусловило их преимущественное распространение.

Исторически сложившийся опыт коренного населения, а также совокупность природно-климатических условий определили овцеводство в регионе как наиболее эффективную отрасль. В овцеводстве занято более 70 \% сельского населения. Баранина является основным продуктом питания населения, спрос на нее с каждым годом увеличивается. Востребована шерсть и овчина для мини-цехов по производству войлока и выделке шкур. Овцеводство определяло не только состояние сельской экономики, во многом сформировало социально-экономический облик, традиции и уклад жизни местного населения.

Тувинские короткожирнохвостые овцы отличаются исключительной устойчивостью к экстремальным условиям, достаточно скороспелы, способны к быстрому нагулу.

Козоводство в республике традиционно является одной из основных отраслей животноводства, развитию которого способствует наличие обширных естественных пастбищных угодий, расположенных на крутых каменистых склонах, а также в полупустынных степях, которые с учетом сложности релье- 
фа, небольшой кормоемкости и труднодоступности наиболее эффективно используются козами. Республика Тыва считается одним из основных центров в России по разведению коз шерстного направления продуктивности и занимает одно из ведущих мест по численности поголовья.

Постановление «0 мерах по государственной поддержке чабанов, имеющих 1000 и более голов мелкого рогатого скота», принятое в сентябре 2010 г., предусматривает большой перечень государственной поддержки чабановтысячников и их семей. Создан Клуб чабанов-тысячников из числа физических лиц, имеющих поголовье мелкого рогатого скота в количестве более 1000 голов. В республиканском Реестре чабанов-тысячников на 2013 г. числятся в количестве 50 личных подсобных и крестьянско-фермерских хозяйств, в 2014 г. 62 хозяйств чабанов-тысячников [5].

Коневодство в республике является традиционной отраслью животноводства. В условиях региона круглогодичное табунное содержание лошадей на пастбищных кормах почти без дополнительных затрат на подкормку и строительство капитальных помещений является экономически эффективным способом получения дешевого мяса.

Племенное дело в животноводстве является базой его развития. Имея небольшой удельный вес в маточном стаде: 3-5 \% в племенных заводах и в племенных репродукторах 5-10 \% это поголовье является определенным в генетическом потенциале породных и продуктивных качеств всего стада. На этом зиждется вся работа животноводства, ведения селекционного процесса.

Современная племенная база животноводства представлена в агропромышленном комплексе региона 28 племенными хозяйствами по разведению тувинской короткожирнохвостой породы овец, коз советской шерстной породы, лошадей тувинской породы, яков, оленей и верблюдов.

Вместе с тем, перечень проблем обеспечения поступательного экономического развития сельского хозяйства сохраняется. Замедление экономического роста в сельском хозяйстве, отсутствие условий для альтернативной занятости на селе, исторически сложившийся низкий уровень развития социальной и инженерной инфраструктуры обусловили обострение социальных проблем села.

При наличии резервов потенциал производимой животноводческой продукции используется не в полной мере. Основными причинами являются сохранение ограниченности рынка сбыта и энергодефицита, низкой техникотехнологической оснащенности в сельской местности.

На перспективу развития животноводства нацелена региональная Государственная программа «Развитие сельского хозяйства и регулирование рынков сельскохозяйственной продукции, сырья и продовольствия в Республике Тыва на 2014-2020 годы», определяющая цели, задачи и направления развития сельского хозяйства, пищевой и перерабатывающей промышленности, меры государственной аграрной политики в республике на среднесрочную перспективу.

В животноводстве планируется наращивание объемов производства мяca, молока, яиц за счет улучшения генетического потенциала животных, госу- 
дарственной поддержки племенных организаций, создания благоприятных условий для инвестиционной политики, внедрения энергосберегающих технологий.

\section{Список литературы:}

1. Конституция Республики Тыва от 6 мая 2001 г.

2. Монгуш С.С. Основные направления развития животноводства // Научное обеспечение инновационного развития АПК. ГНУ Тувинский НИИСХ Россельхозакадемии. ФГБОУ ВПО «Тувинский государственный университет». Кызыл: РИО ТувГУ, 2013. С. 54-55.

3. Оюн С.М. Становление, современное состояние и перспективы развития племенной работы в животноводстве Республики Тыва // Единая Тува в единой России: история, современность, перспективы. Кызыл. ІІ Ч. С. 175-178.

4. Поголовье скота в Республике Тыва на 1 января 2014 года. Тывастат, по каталогу статизданий № 14.03. г. Кызыл. С. 3.

5. Постановление Правительства Республики Тыва от 15 сентября 2010 г. № 375 «О мерах по государственной поддержке чабанов, имеющих 1000 и более голов мелкого рогатого скота». 6. Республика Тыва в цифрах. Краткий статистический сборник. Тывастат. Кызыл, 2014. С. 37. 7. Состояние индивидуального сектора сельского хозяйства Республики Тыва (аналитическая записка). Тывастат. г. Кызыл. С. 2-3.

8. Сельское хозяйство, охота и лесоводство в Республике Тыва: Статистический сборник. Тывастат Республики Тыва. Кызыл, 2013.

(C) 2015, Ховалыг Р.Б.

Животноводство - приоритетное направление в сельском хозяйстве региона
(C) 2015, Khovalyg R.B.

Livestock - priority to agriculture in the region 
Науки о земле

DOI: 10.17117/na.2015.05.191

Поступило в редакцию: 20.05.2015

\title{
Шишлова М.А., Ханкова С.А. Детергенты в речных водах г. Уссурийска \\ (Приморский край)
}

\author{
Shishlova M.A., Hankova S.A. \\ Detergents in river waters of Ussuriisk (Primorsky Krai)
}

В статье содержатся сведения о содержании детергентов в водах водотоков г. Уссурийска (Приморский край) в весенний, летний и осенний периоды. Исследования показали увеличение концентрации поверхностно-активных веществ в весенний период. Пробы воды, взятые в водотоках после воздействия на них антропогенного пресса, содержали концентрации детергентов, превышающие предельно допустимые для рыбохозяйственных водоёмов в 1,8-3,3 раза

Ключевые слова: детергенты, пресные воды, загрязнение

\section{Шишлова Марина Александровна}

Кандидат биологических наук, доцент Дальневосточный федеральный университет Приморский край, г. Уссурийск, ул. Некрасова, 35

\section{Ханкова Софья Андреевна}

Студент

Дальневосточный федеральный университет

Приморский край, г. Уссурийск, ул. Некрасова, 35

\begin{abstract}
The article provides information about the content of the detergents in the waters of the watercourses of Ussuriisk (Primorsky Krai) in the spring, summer and autumn periods. Studies show an increase in the concentration of surfactants in the spring. The water samples taken in streams after exposure to anthropogenic pressure, contained concentrations of detergents exceeding the maximum allowable for the level of commercial fishing ponds 1.8-3.3 times
\end{abstract}

Key words: detergents, fresh water, pollution

\author{
Shishlova Marina Aleksandrovna \\ Candidate of Biological Sciences, Associate Professor \\ Far Eastern federal university \\ Primorsky Krai, Ussuriisk, Nekrasova st., 35 \\ Hankova Sofia Andreevna \\ Student \\ Far Eastern federal university \\ Primorsky Krai, Ussuriisk, Nekrasova st., 35
}

Наряду с такими распространенными и достаточно хорошо изученными загрязняющими веществами, как тяжелые металлы и нефтяные углеводороды, в реки и моря поступают детергенты, постоянно присутствующие в недостаточно очищенных бытовых стоках. Поверхностно-активные вещества являются непременной составной частью большинства моющих средств. О возможных масштабах такого загрязнения биосферы свидетельствуют статистические данные: годовое потребление стиральных порошков достигает 10 - 12 кг на одного человека.

Возросшая потребность в СПАВ на промышленных предприятиях, их использование в быту, приводит к большим скоплениям пены в руслах рек и водоемах. Поступая в водные объекты, пена распространяется на значительные расстояния, осаждается на берегах, разносится ветром [3, 4]. 
Присутствие СПАВ резко ухудшает органолептические свойства воды: уже при концентрациях СПАВ равной 1-3 мг/л вода приобретает неприятный вкус и запах, интенсивность которых зависит от химической структуры СПАВ. Роль детергентов в изменении трофического состояния водоемов заключается в том, что присутствие их в воде снижает ее способность насыщаться кислородом. В поверхностном слое воды молекулы СПАВ перехватывают фотоны света и тем самым тормозят прохождение фотосинтеза.

Многие работы по исследованию содержания детергентов в Приморском крае посвящены морским экосистемам [2]. Вопрос о содержании детергентов в пресных речных водах Приморского края, в частности г. Уссурийска, остается частично нераскрытым.

Основными источниками загрязнения водоемов СПАВ являются промышленные предприятия, применяющие их (в первую очередь текстильные и кожевенные), а также предприятия, производящие детергенты для бытовых нужд, и прачечные. Кроме того, водоемы могут загрязняться водами поверхностного стока с полей, обработанных пестицидами, содержащими СПАВ в качестве эмульгаторов и смачивателей. Однако основной причиной загрязнения водоемов этими веществами считают бытовое использование детергентов и поступление их с бытовыми сточными водами [1].

Основное влияние СПАВ оказывают на среду обитания гидробионтов; незначительно изменяют прозрачность и окраску растворов. Большое значение имеет их способность придавать воде запахи и привкусы, часто лимитирующие их распространение в водоемах. Весьма важным является также способность СПАВ к пенообразованию. Пена препятствует аэрации водоемов, ухудшая процессы их самоочищения, в ней концентрируются органические загрязнения и микрофлора (в том числе патогенные микроорганизмы) [5].

При концентрации моющих средств 1 мг/л гибнет планктон, при 3 мг/л дафнии, 15 мг/л - рыбы. Разложение большого количества органических веществ в стоках приводит к дефициту кислорода и накоплению сероводорода, в результате чего со временем такие водоемы «умирают».

В естественной водной среде СПАВ разлагаются и подвергаются биохимическому окислению. На процесс активно влияют природные условия: температура воды, соленость, гидрохимический режим, наличие примесей. Причем биохимическое окисление протекает последовательно - одна ферментная реакция за другой. И если хотя б одна реакция останавливается, то, соответственно, и разложение вещества прекращается и не идет дальше. А промежуточные продукты распада накапливаются в грунте и осадочных породах. По этим причинам на мелководных участках водоемов уже отсорбированные молекулы СПАВ, соединяясь с иными загрязняющими веществами, могут служить источником вторичного загрязнения и усиливать токсическое воздействие других загрязнителей.

Таким образом, целью нашей работы стало исследование содержание детергентов в природных пресных водах Приморского края.

Районом работ выбраны основные водотоки г. Уссурийска - р. Раковка, р. Комаровка, р. Раздольная. 
Приморский край относится к территории с муссонным климатом, поэтому реки имеют преимущественно дождевое питание. Снежный покров, формирующийся за зиму, невелик, а питание грунтовыми водами относительно слабое.

Особенностью рек Раковка, Комаровка и Раздольная является высокая динамичность их режима - изменчивость по сезонам года и годам, резко выраженная неравномерность стока. Своеобразный режим и неустойчивость муссонных осадков обуславливают наличие у р. Раковки, р. Комаровки и р. Раздольной двух максимумов стока (весеннего и летне-осеннего) и минимума зимой.

Для рек Раковка, Комаровка и особенно Раздольная характерными являются паводки, следствием паводков - катастрофические наводнения. Дождевые паводки наблюдаются обычно до сентября, но в отдельные годы проходят в октябре и даже начале ноября. Средние максимальные расходы воды в это время превышают минимальные летние в 10 - 25 раз. Весеннее половодье наступает в апреле - мае, на это время приходится до 20 - 30 \% годового стока.

Пункты отбора проб были выбраны так, чтобы можно было проанализировать влияние техногенного и антропогенного пресса на качество речной воды (рис.1):

Пункт №1 - участок р. Комаровка, расположенный перед ОАО «Примснабконтракт» (картонный комбинат). Данный участок реки дает представление о качестве речной воды, до воздействия на водоток города;

Пункт №2 - участок р. Комаровка, расположенный после слияния с р. Раковка. Этот район города низменный и в период длительных дождей и следующих за ними паводков, подвергается сильному затоплению;

Пункт №3 - участок р. Раковка, расположенный после п. Тимирязевский, дает представление о качестве речной воды до города;

Пункт №4 - участок р. Раковка, расположенный перед слиянием с р. Комаровка. Сильно загрязненный участок реки, характеризующий воздействие города на данный водоток.

Р. Раздольная не протекает по Уссурийску, но принимает сбросы городских очистных сооружений и загрязненную городом р. Комаровка. Мы попытались проследить изменение концентрации детергентов в р. Раздольная, вызванное техногенным и антропогенным воздействием города, пункты отбора проб выбрали следующим образом:

Пункт №5 - участок р. Раздольная до г. Уссурийска (район с. Борисовка), который дает представление о качестве речной воды до воздействия города.

Пункт № 6 - участок р. Раздольная, расположенный в районе ж/д станции после очистных сооружений канализации МУП «Уссурийск-водоканал».

Материалом послужили результаты наблюдений за уровнями содержания детергентов в пресной воде водотоков г. Уссурийска, выполненных в 20142015 гг. в летний, осенний и весенний периоды. Пробы воды отбирались из поверхностного слоя и анализировались не позднее 12 ч после отбора. Анионные СПАВ - основной компонент детергентов - определяли общепринятым фотоколориметрическим методом с метиленовым синим. 


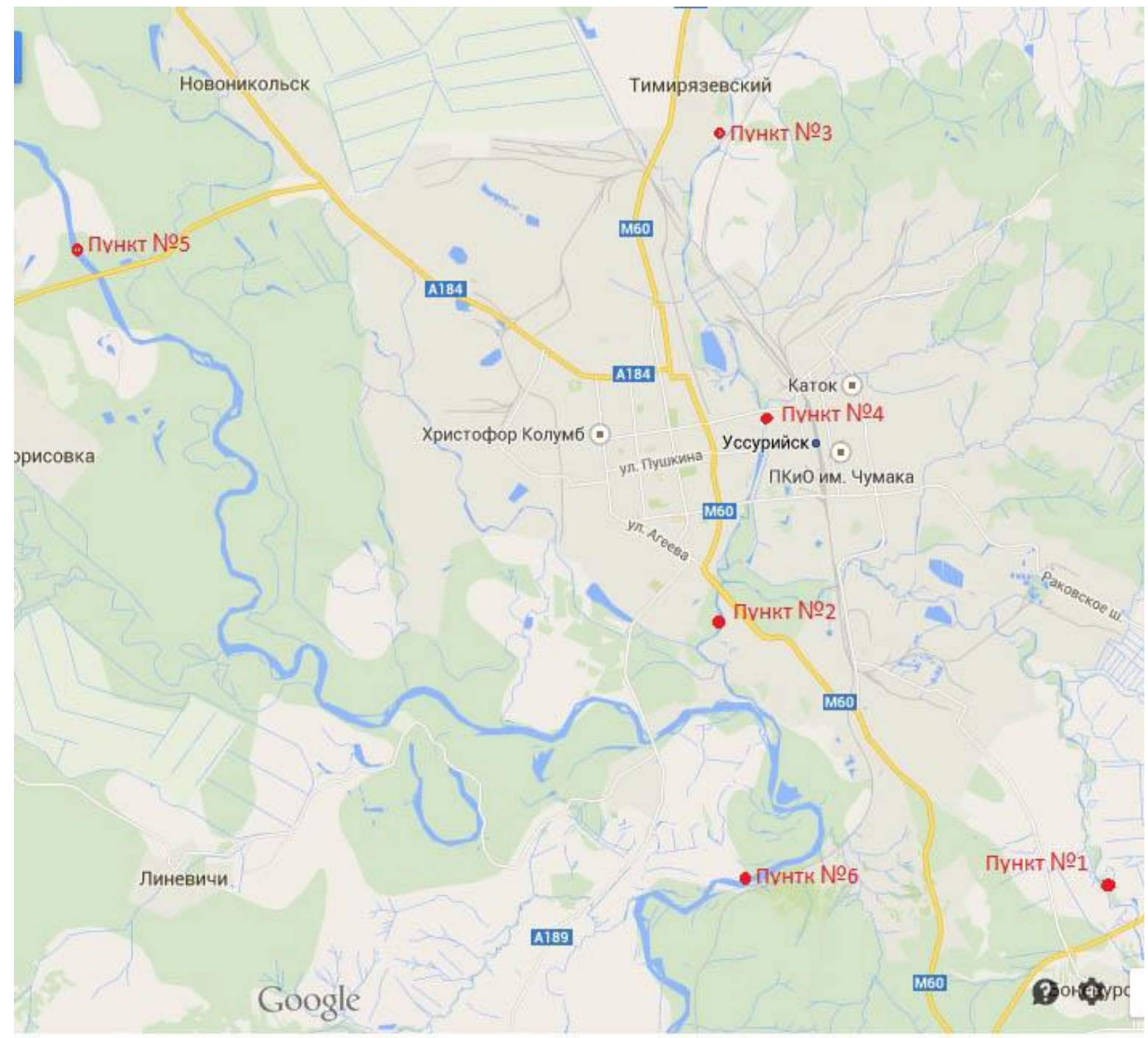

Рис. 1. Схема водотоков г. Уссурийска

Метод основан на образовании окрашенного соединения при взаимодействии анионноактивных веществ с метиленовой синей, экстрагируемого хлороформом. Для устранения мешающего влияния хлоридов, нитратов, роданидов и белков хлороформный экстракт промывают кислым раствором метиленовой синей и затем измеряют его оптическую плотность при $\lambda=650$ нм. Линейная зависимость между оптической плотностью растворов и концентрацией анионноактивных СПАВ сохраняется в пределах от 15 до 250 мкг/л [5].

Результаты определений представлены на рисунке 2. Гидрохимические работы выполнялись преимущественно в летнее, осеннее, весеннее время, так как в Приморском крае в связи с климатическими условиями на июль-сентябрь чаще всего приходится основное прохождение тайфунов, сопровождающихся ливневыми дождями и паводками на реках. В весенний период наблюдается таяние льдов и как следствие наступает период «высокой воды», когда сток рек становится максимальным, и вынос растворенных загрязняющих веществ усиливается. Таким образом, содержание детергентов изучалось именно в те сезоны, когда ожидалось повышение их концентрации.

Как видно из гистограммы, в летний период 2014 г. определенный нами диапазон концентраций анионных СПАВ составлял 26-43 мкг/л и их содержа- 
ние не превышало ПДК для рыбо-хозяйственных водоемов, равную 100 мкг/л [6]. Наименьшие концентрации детергентов наблюдались на ст.1 (верховье р. Комаровка) и станциях 3, 4 (р. Раковка); наибольшее содержание СПАВ наблюдались в водах р. Раздольная.

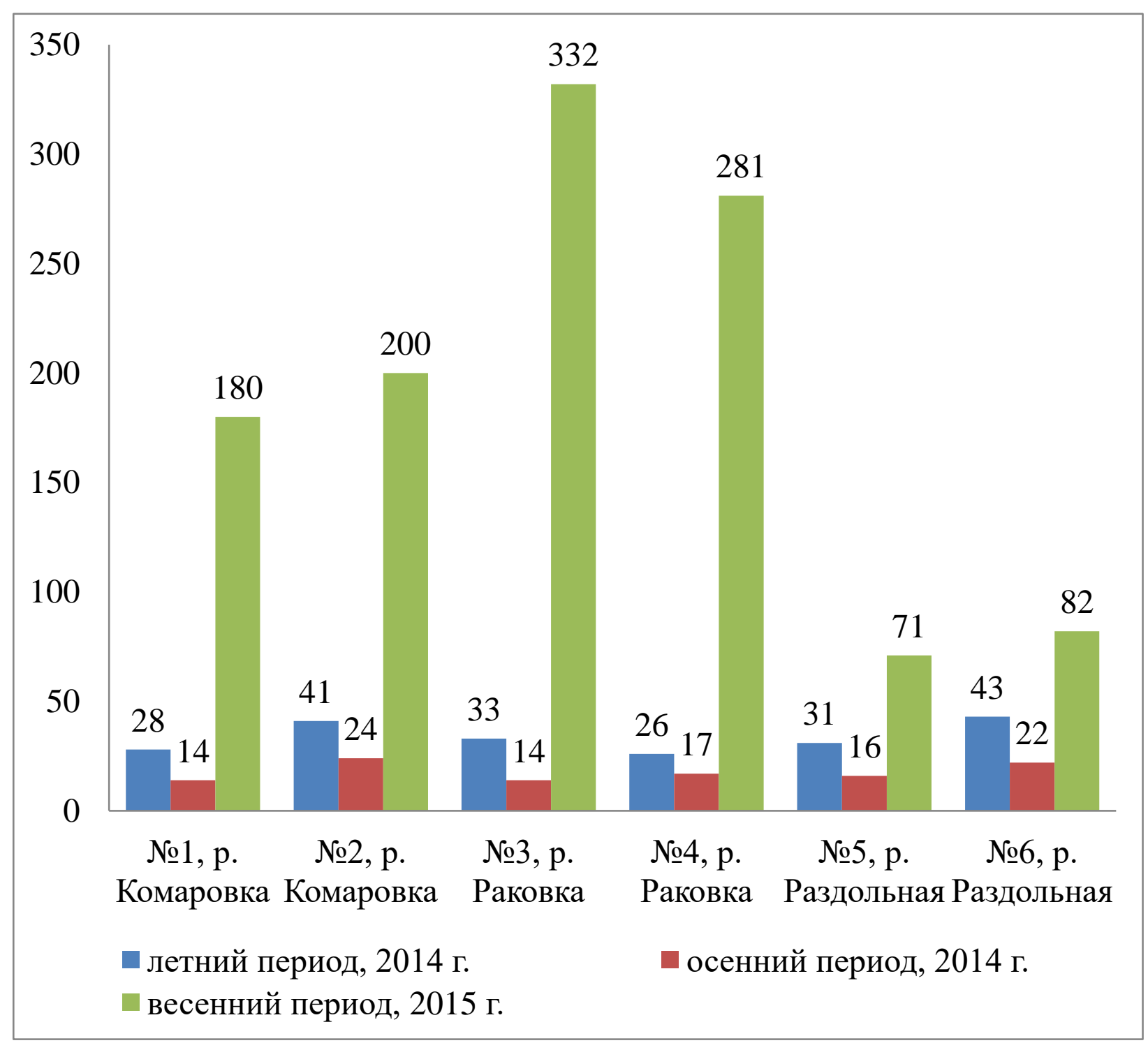

Puс. 2. Среднее содержание детергентов в пресных водах водотоков г. Уссурийска, мкг/л, $n=6$

В осенний период концентрации СПАВ в пробах воды со всех станций не сильно различалась: от 14 мкг/л до 24 мкг/л и не превышала ПДК р.х. В весенний период 2015 г. определенный нами диапазон концентраций анионных СПАВ составлял 71-332 мкг/л и их содержание превышало ПДК для рыбохозяйственных водоемов на ст.1-4 от 1,8 до 3, 32 раза. Особенно высокое содержание детергентов отмечено в пробах из р. Раковка, можно предположить воздействие недостаточно очищенных сточных вод ЗАО УМЖК «Приморская соя» и МУП «Уссурийск-Водоканал»

Сезонная изменчивость содержания анионноактивных СПАВ в пробах речной воды из всех наблюдаемых нами рек прослеживается очень четко: высоким содержанием детергентов в воде в весенний период, затем снижением 
концентрации СПАВ к лету и минимальным значением концентраций загрязняющих веществ - осенью.

Выявленные концентрации детергентов в водотоках г. Уссурийска оказались невысокими; в большинстве случаев они не превышали ПДК для рыбохозяйственных водоемов, за исключением наблюдений в весенний период. Известно, пороговые концентрации детергентов, влияющих на жизнедеятельность гидробионтов равны 100-110 мкг/л. Следовательно, загрязнение обследованных рек вносит вклад в ухудшение общей химико-экологической ситуации региона.

\section{Список литературы:}

1. Гидрохимические показатели состояния окружающей среды: справочные материалы. М.: ФОРУМ: ИНФРА-М, 2007. 192 c.

2. Журавель Е.В. Детергенты в водах залива Петра Великого и их влияние на морскую биоту: автореф. дис. канд. биол. наук. Владивосток, 2001. 26 с.

3. Исидоров В.А. Экологическая химия. СПб.: Химиздат, 2001. 304 c.

4. Можаев Е.А. Загрязнение водоемов поверхностно-активными веществами. М.: Медицина, 1976. $124 c$.

5. Потенко Е.И., Жукова Н.И. Химико-экологический мониторинг водных объектов: учебное пособие для вузов региона по спец. 050101 "Химия", 050102 "Биология", 020801 "Экология". Уссурийск: УГПИ, 2010. $80 \mathrm{c}$.

6. СанПиН 2.1.5.980-00 «Гигиенические требования к охране поверхностных вод».

(C) 2015, Шишлова М.A., Ханкова С.А. Детергенты в речных водах г. Уссурийска (Приморский край)
(C) 2015, Shishlova M.A., Hankova S.A. Detergents in river waters of Ussuriisk (Primorsky Krai) 


\title{
Гуляева В.Н., Евтихиева А.Н., Наумов А.И., Рябикова Л.А., Золотова Т.В., Федоров А.С. Образование и перспективы развития образовательной системы XXI века
}

\author{
Gouliaeva V.N., Evtikhieva A.N., Ryabikova L.A., \\ Naumov A.I., Zolotova T.V., Fedorov A.S. \\ Education and prospects of development of \\ educational systems of the XXI century
}

Сегодня стала очевидной слабая практическая и деятельностная направленность образовательного процесса, ограниченность ориентации образовательного учреждения на передачу студентам основ наук. Невозможно достичь нового качества образования, соответствующего потребностям развития общества, за счет увеличения объема знаний или за счет изменения содержания знаний по отдельным предметам. Необходимы другие подходы для подготовки к жизи в динамично меняющихся условиях

Ключевые слова: совместная деятельность, успех, результат, профессиональная ориентация, профессиональное образование, профессиональная трудовая деятельность

\section{Гуляева Вера Николаевна}

Методист

Нелидовский колледж

Тверская область, г. Нелидово, ул. Лесная, 12

\section{Евтихиева Анжелика Николаевна}

Директор

Нелидовский колледж

Тверская область, г. Нелидово, ул. Лесная, 12

\section{Золотова Татьяна Владимировна}

Преподаватель

Нелидовский колледж

Тверская область, г. Нелидово, ул. Лесная, 12
Today it became obvious weak practical and activity directivity of the educational process, the orientation's narrowness of the educational institution for the transfer students the fundamentals of science. It is impossible to achieve a new quality of the education that meets the needs of social development, at the expense of increasing of knowledge amount or at the expense of change of knowledge content in particular subjects. It is necessary to have other approaches to preparing for life in a rapidly changing environment

Key words: joint activity, success, result, professional orientation, professional education, professional labor activity

\author{
Gulyaeva Vera Nikolaevna \\ Methodist \\ College of Nelidovo \\ Tver region, Nelidovo, Lesnaya st. 12
}

Evtikhieva Anzhelika Nikolaevna

Director

College of Nelidovo

Tver region, Nelidovo, Lesnaya st. 12

\author{
Zolotova Tatiana Vladimirovna \\ Teacher \\ College of Nelidovo \\ Tver region, Nelidovo, Lesnaya st. 12
}




\section{Наумов Андрей Иванович}

Мастер производственного обучения

Нелидовский колледж

Тверская область, г. Нелидово, ул. Лесная, 12

\section{Рябикова Лариса Анатольевна}

Преподаватель

Нелидовский колледж

Тверская область, г. Нелидово, ул. Лесная, 12

\section{Федоров Александр Сергеевич}

Мастер производственного обучения

Нелидовский колледж

Тверская область, г. Нелидово, ул. Лесная, 12
Naumov Andrey Ivanovich

Master of industrial training

College of Nelidovo

Tver region, Nelidovo, Lesnaya st. 12

Ryabikova Larisa Anatolyevna

Teacher

College of Nelidovo

Tver region, Nelidovo, Lesnaya st. 12

Fedorov Aleksandr Sergeevich

Master of industrial training

College of Nelidovo

Tver region, Nelidovo, Lesnaya st. 12

Стремительно меняющийся мир и технологизированность современной жизни диктуют необходимость создания новой образовательной системы XXI века. Переход от постиндустриального к информационному типу общества, изменение системы отношений студентов к миру, доминирование смысловой сферы в их сознании требуют нового взгляда на построение образовательного процесса. Развитие человеческой цивилизации, технологическое и культурное разнообразие стало опережать способность человека осмысливать новые явления, учитывать риски и прогнозировать перспективы, и, соответственно, требует переориентации системы образования, ставит перед необходимостью новых подходов к подготовке активного, думающего человека, способного к решению практических задач, понимать и формулировать смыслы человеческой деятельности, способного на эффективное социальное сотрудничество для достижения общего результата.

Сегодня стала очевидной слабая практическая и деятельностная направленность образовательного процесса, ограниченность ориентации образовательного учреждения на передачу студентам основ наук. Невозможно достичь нового качества образования, соответствующего потребностям развития общества, за счет увеличения объема знаний или за счет изменения содержания знаний по отдельным предметам. Необходимы другие подходы для подготовки к жизни в динамично меняющихся условиях.

Очень скоро в системе СПО окажется новое поколение студентов, которое значительно отличается от сверстников прошлого века. Образовательные потребности нового поколения студентов связаны с необходимостью увеличения скорости обучения, широкого использования мультизадачности и умения заинтересовывать, применение новых методик для формирования самостоятельности мысли и действия, мотивации к новому, переменам.

ФГОС СПО открыли перед педагогом широкие возможности для проявления инициативы, педагогического творчества, проведения педагогических экспериментов. Одним из главных подходов в построении нового содержания образования стал метапредметный подход, заложенный в основу стандартов. И хотя разные научные школы рассматривают его с разных позиций, все же выделяются определенные области пересечения, такие как метапредметное содержание и метапредметная деятельность. 
Метапредметный подход предполагает создание таких условий, при которых студент будет учиться мыслить и действовать самостоятельно, получать опыт решения проблем, а не заучивать формулировки и алгоритм действий. Важный момент при метапредметном подходе - осознание изменения характера связей и отношений между учебными дисциплинами, которые определяются, прежде всего, целями общего образования. Возникает вопрос о метапредметном типе интеграции, при которой речь идет не о параллельном изучении одной темы на двух разных уроках, а о междисциплнарном взаимодействии на уровне содержания, на уровне формирования способностей к определенным типам деятельности, направленным на добывание знаний самостоятельным путем.

Стратегия развития системы подготовки рабочих кадров и формирования прикладных квалификаций на период до 2020 года определяет основные направления государственной политики в области подготовки квалифицированных рабочих (служащих) и специалистов среднего звена в Российской Федерации на долгосрочную перспективу. Одной из важнейших проблем развития профессионального образования является разработка и реализация новой образовательной модели, обеспечивающей интерактивную подготовку конкурентоспособных выпускников для экономики региона на полисубъектной диалогической основе.

Деятельность образовательного учреждения в современных условиях не регламентируется жесткими установками приказов, инструкций, положений чему и как учить. Перед педагогом профессионального образования поставлены новые задачи по повышению эффективности воспитания, обучения и развития молодого рабочего или специалиста, успешное решение которых возможно при условии постоянного совершенствования педагогического мастерства и достижения высокого уровня учебно-воспитательного процесса. В число приоритетных направлений развития профессионального образования входят:

- обновление структуры, содержания и технологий реализации диверсификационных программ с учетом требования работодателей, студентов, а также с учетом прогноза рынка труда и социально-экономического развития региона;

- внедрение системы сертификации и признания профессиональных квалификаций;

- формирование современной системы непрерывного образования;

- создание многофункциональных центров прикладных квалификаций, корпоративных образовательных организаций;

- развитие кадрового потенциала руководящих и педагогических работников образовательных организаций и повышение эффективности их деятельности.

В настоящее время реализация программ профессионального обучения осложняется тем, что отсутствуют простые и ясные критерии разработки структурных элементов образовательной программы, возникают сложности в оценке сформированности умений, требуется обновление учебно- 
программного и методического обеспечения процедур разработки средств оценивания результатов обучения в компетентностном формате.

А это в немалой степени зависит от профессионализма преподавателя интегрированных фундаментальных знаний, умений и способностей, а также творческого подхода к организации педагогической деятельности и готовности к постоянному саморазвитию.

По результатам анализа квалификации педагогов ГБПОУ «Нелидовский колледж» смело можно сказать, что в нашем коллективе работают высококвалифицированные специалисты, преданные своему делу. Из 31 инженернопедагогического работника 27 имеют высшее образование, 3 учатся без отрыва от производства в высших учебных заведениях заочно. Высшая категория у 23 работников, первая - у 6, остальные аттестованы на соответствие.

Еще одной приоритетной задачей педагогического сообщества является подготовка высококвалифицированных и востребованных на рынке труда специалистов разного уровня: от рабочих кадров до инженеров - управленцев высшего звена. Одним из ключевых рычагов для реализации данной задачи служит создание некой информационной базы, служащей промежуточным звеном между выпускником учебного заведения и работодателем - заказчиком кадров. Функции подобной информационной базы:

- помочь выпускникам учебных заведений получить работу, по возможности быстро и в максимальной степени удовлетворяя потребности двух сторон - соискателя и работодателя;

- помочь школьникам еще при учебе в школе определиться с выбором будущей профессии или специальности.

В современных социально-экономических условиях отмечается повышенное внимание к организации целенаправленной профессиональной ориентации школьников и молодежи. Существенно меняются задачи, содержание и методы сложившейся системы, направленные на подготовку молодого человека к социально-профессиональному самоопределению, профессиональной карьере, с учетом вызова времени.

Об актуальности данной проблемы свидетельствуют факты:

- развитие демографической ситуации в России указывает на уменьшение численности трудоспособного населения, при этом уже через десятьдвадцать лет в России один работоспособный человек должен будет содержать двух неработоспособных;

- приток трудовых мигрантов предопределяет усилие конкуренции за рабочие места между гражданами России и трудовыми мигрантами, нежелание значительной части работодателей вкладывать ресурсы в подготовку и переподготовку кадров;

- год от года нарастает несоответствие профессиональноквалификационного состава трудоспособного населения ситуации на рынке труда, одновременно на нем увеличивается доля малопривлекательных для молодежи рабочих мест с низкой оплатой;

- все шире распространяются виртуальные формы организации труда, частичная занятость и «самозанятость». На постоянную высокооплачиваемую 
работу стремятся приглашать тех, кто способен быстро осваивать новое, решать нестандартные задачи.

В программе «Рабочие кадры» подчеркивается, что только 3,6\% школьников в ходе выявления у них профессиональных предпочтений заявили о готовности обучаться по рабочим профессиям, что почти в 10 раз ниже показателей 20-летней давности. В создавшейся ситуации как никогда обостряются противоречия между:

- потребностью общества в ответственных, социально значимых поступках граждан и государственной образовательной политикой;

- потребностью государства и бизнеса в кадровом обеспечении в соответствии с динамичным запросом рынка труда и отсутствием государственного статуса (заказа на профессиональную ориентацию молодежи);

- необходимостью для человека совершать осознанный выбор целей, методов, форм, критериев деятельности и недостатком социальнопедагогических условий для приобретения соответствующего опыта;

- потенциальными возможностями социума и недостаточным уровнем сотрудничества его представителей с образовательными учреждениями.

В настоящее время проблема социализации подростков в целом и значимость подготовки будущих выпускников школы к выбору направления дальнейшего образования и профессии в частности, заявлена в «Законе об образовании в Российской Федерации», Государственной программе Российской Федерации «Развитие образования» на 2013-2020 годы, Плане деятельности Министерства образования и науки Российской Федерации на 2013-2018 годы и других нормативных документах.

Глава Минобрнауки РФ Дмитрий Ливанов на заседании Правительства сообщил о подготовке комплекса мер, направленного на решение трех системных задач: обеспечение соответствия квалификации выпускников требованиям современной экономики, консолидация ресурсов бизнеса и государства на ускоренном развитии системы СПО и контроль за качеством подготовки кадров.

Все вышесказанное требует серьезного пересмотра и обновления решения проблемы профессиональной ориентации школьников и молодежи, создания комплекса условий для повышения ее качества. Одним из актуальных практических способов развития профессиональной ориентации в сложившихся условиях является организация эффективного социального партнерства.

Социальное партнерство - это система взаимодействия социальных субъектов, интересы которых принципиально различны, а иногда и противоположны, однако их достижение интересов невозможно без определенного согласования позиций субъектов.

Особенностью социального партнерства выступает ситуация взаимодействия, при которой субъекты профессиональной ориентации становятся перед необходимостью думать и действовать сообща, при этом возникает потребность в согласовании их ценностей и интересов. Именно ценности определяют «вектор» партнерских отношений, выбор средств взаимодействия и позволяют согласовывать или не согласовывать индивидуальные позиции. 
Социальное партнерство в профессиональной ориентации можно рассматривать в нескольких контекстах:

- партнерство внутри системы образования между социальными группами определенной профессиональной общности;

- партнерство, в которое вступают работники образовательной организации, контактируя с представителями иных сфер общественного воспроизводства;

- партнерство, которое инициирует система образования как особую сферу социальной жизни, делающую вклад в становление гражданского общества.

Профессиональная ориентация молодого поколения - это комплексный процесс, включающий взаимосвязанную деятельность педагогического коллектива с социальными партнерами.

Основными этапами развертывания механизма становления социального партнерства в профессиональной ориентации молодежи являются:

- осознание противоречий в действиях субъектов профессиональной ориентации, которые находятся в ситуации взаимозависимости, осознанием внешней необходимости сотрудничества, пониманием его неизбежности;

- поиск общих элементов в системе ценностей каждого из взаимодействующих субъектов, выработка представлений об общем, в целях, ценностных ориентациях, установках, объединяющих потенциальных партнеров;

- выработка общей стратегии действий: переговоры, консультации, согласования;

- определение места и роли каждого субъекта в системе новых партнерских отношений. Субъекты партнерства реализуют свои собственные цели и умело дополняют усилия участников совместной деятельности в решении коллективных задач;

- осуществление специальной аналитической работы после каждого цикла совместных действий для выявления позитивных и негативных факторов, обеспечивающих получение конкретного результата.

Важная роль в обеспечении социального партнерства в профессиональной ориентации молодежи принадлежит:

- взаимному признанию важности интересов сторон-партнеров;

- паритетности в партнерских отношениях;

- социальной справедливости при регулировании действий;

- поиску компромиссов при решении вопросов профориентации молодежи;

- взаимной ответственности сторон за исполнение (и неисполнение) согласованных решений по вопросам профессиональной ориентации.

Развитие социального партнерства в профессиональной ориентации сегодня требует решения ряда задач:

- разработки и внедрения модели взаимодействия социальных партнеров (общеобразовательные организации, средние профессиональные и высшие учебные заведения, служба занятости, государственные предприятия, 
бизнес, семья, СМИ и другие учреждения) в подготовке молодежи и школьников к выбору или перемене профессий, востребованных на рынке труда;

- разработки научно-методических основ психолого-педагогического сопровождения социально-профессионального самоопределения молодого поколения на профессии, востребованные инновационной экономикой (с учетом реальных и прогнозируемых потребностей рынка труда);

- создание дистанционной службы профессиональной ориентации для информационного взаимодействия с социальными партнерами и профессионального консультирования по запросам молодежи;

- научно-методическое и практическое обеспечение подготовки преподавателей, мастеров производственного обучения и других специалистовпрофориентологов к профессиональной ориентации в общеобразовательной организации, колледже, ВУЗе, службе занятости.

Необходимо, чтобы не менее половины учебного времени студенты проводили на производственных площадках или в учебно-тренировочных центрах. Кроме того, необходимо участие работодателей в управлении региональными системами подготовки кадров на всех этапах - от профориентации до трудоустройства.

Пока такие тандемы, к сожалению, встречаются редко. Одним из них является сотрудничество ЗАО «Нелидовский завод гидравлических прессов» и ГБПОУ «Нелидовский колледж». С первых месяцев обучения студенты проходят учебную и производственную практику в цехах завода под руководством мастера производственного обучения и наставника, назначенного администрацией завода, студентам дополнительно выплачивается стипендия от завода, за работу начисляется заработная плата. По окончании учебы они становятся равноправными членами коллектива, заработная плата не меньше средней по заводу.

Хочется отметить, что и Администрация района заинтересована в молодых квалифицированных работниках, которые будут работать более чем на 32 предприятиях города Нелидово. Ежемесячно лучшим студентам колледжа выплачиваются две стипендии по 1500 рублей от Главы Нелидовского района. Выпускникам, получившим дипломы с отличием, Администрация Нелидовского района учредила поощрительную премию в размере 2000 рублей. Ежегодно студенты колледжа с преподавателями имеют возможность выезжать на Bсероссийские форумы, которые проходят под эгидой научного сообщества «Интеграция», где организационный взнос составляет около 15000 рублей на человека, а оплатить взносы помогает завод и администрация города.

А вот качество работы педагогического коллектива колледжа можно проследить по премиям и грантам. У нас работает заслуженный учитель Российской Федерации, три отличника профессионального образования РСФСР, почетный работник среднего профессионального образования и почетный работник начального профессионального образования Российской Федерации. Только за последние три года студентами и преподавательским составом получены награды: 
- четыре работника получили звание «Почетный работник науки и образования Тверской области»;

- участвуя в конкурсе «Преподаватель года - 2014», Наумов А.И. стал победителем в номинации «Мастер производственного обучения - 2014», выигран заочный этап конкурса «Преподаватель года - 2015», Шляхтина И.Г. будет представлять наш колледж на очном конкурсе в конце апреля, надеемся, что результат будет не хуже прошлогоднего;

- студент и его научный руководитель стали обладателями знака отличия «Депутатский резерв»;

- награждены дипломами 1 степени 23 студента и 7 преподавателей, дипломами второй степени - 18 и 7, дипломами 3 степени - 14 и 8 соответственно, за участие в конкурсах и подготовку призеров все преподаватели и мастера производственного обучения имеют не по одному благодарственному письму.

Профориентационные мероприятия проводятся совместно представителями колледжа и социальных партнеров, кроме того, организуются профессиональные конкурсы, мастер-классы, студенты участвуют в профессиональных праздниках на предприятиях, а представители работодателей - постоянные участники конкурсов, олимпиад профессионального мастерства и конференций, проводимых колледжем. Всё это позволяет поднять престиж рабочих профессий и специальностей СПО и привлекает выпускников школ для обучения в колледже.

Возросшие требования современного производства к уровню профессиональной подготовленности кадров в еще большей, чем раньше, степени актуализируют проблемы профессиональной ориентации молодежи, поскольку профессиональные намерения значительной части учащихся зачастую не соответствуют потребностям народного хозяйства в кадрах определенной профессии.

Подготовка к выбору профессии важна еще и потому, что она является неотъемлемой частью всестороннего и гармоничного развития личности, и ее следует рассматривать в единстве и взаимодействии с нравственным, трудовым, интеллектуальным, политическим, эстетическим и физическим совершенствованием личности, то есть со всей системой учебно-воспитательного процесса. Таким образом, можно сделать вывод о том, что профориентация является важным моментом, как в развитии каждого человека, так и в функционировании общества в целом.

Профессиональная трудовая деятельность, которой предшествует правильный выбор, один из важнейших факторов, определяющих многое в жизни современного человека. Огромное преимущество человека заключается в его возможности выбора.

Важным компонентом системы профессиональной ориентации учащихся является профессиональное просвещение - сообщение школьникам сведений о различных профессиях, их значении для народного хозяйства, потребностях в кадрах, условиях труда, требованиях, предъявляемых профессией к психофизиологическим качествам личности, способах и путях их получения, оплате труда. 
Кроме того, учащиеся должны знать основные общетрудовые и общепроизводственные понятия: что такое культура труда, трудовая дисциплина, принципы планирования, структура предприятия и т. п.

Профессиональное воспитание включает в себя формирование склонностей и профессиональных интересов учащихся.

Сущность педагогической работы по профессиональному воспитанию заключается в том, чтобы побуждать учащихся к участию в разнообразных формах учебной и внеклассной работы, общественно-полезному и производственному труду, к активной пробе сил. Это позволяет на практическом опыте узнать и определить свои склонности и способности. Склонность развивается в процессе деятельности, а профессиональные знания успешно накапливаются при наличии профессиональных интересов. Важно, чтобы школьник пробовал себя в самых различных видах деятельности.

Профессиональное воспитание - завершающий этап системы профориентации учащихся. Целью профессионального воспитания является личностное развитие субъекта, формирование профессиональных установок, мотивов, отношений, ценностных ориентаций, обеспечивающих непрерывное развитие, самоактуализацию и полноценное участие в профессиональной жизни.

С усложнением труда в процессе ускоряющегося научно-технического прогресса возможен рост ограничений, касающихся физических и психофизиологических особенностей людей, для некоторых профессий. Наряду с этим в народном хозяйстве нашей страны есть много профессий, которые не предъявляют повышенных физических и психофизиологических требований к человеку. Поэтому очень важно еще на школьной скамье ознакомить учащихся, особенно имеющих физические и психофизиологические ограничения, с данными профессиями, помочь молодым людям выбрать одну из них.

Профессиональная ориентация, направленная на оказание помощи в самоопределении школьников, проводимая с учетом личных интересов, склонностей, способностей, возможностей личности и потребностей рынка труда, была и остается государственной задачей. Ее решение позволит поднять престиж нашей страны как страны с высокотехнологичным производством, обеспечивающей достойный уровень жизни своих граждан.

Инженерно-педагогические работники ГБПОУ «Нелидовский колледж» постоянно ведут профориентационную работу среди школьников не только Нелидовских школ, но и школ близлежащих районов: Бельского, Западнодвинского, Андреапольского, Оленинского и Ржевского. В профориентационной работе принимают участие и студенты колледжа: на нашей базе с 2009 года создана и действует агитбригада.

В заключении можно предположить, что только при осмыслении и построении нового содержания образования, начиная с самоопределния школьников, можно ожидать, что все, что наполняет голову студента, имеет смысл, четкую форму, структуру и осознается им не как знание ради знания, а как то, что нужно ему для жизни. 


\section{Список литературы:}

1. Громыко Н.В. Мыследеятельностная педагогика, метапредметный подход: основания и рамки дидактических исследований и разработок. Красноярск, 2011.

2. Матерова Т.А. Организация профориентации в общеобразовательной школе. Формы профессионального просвещения. Ч. 2. Барнаул, 2007.

3. Половкова М.В. Становление педагогического профессионализма на основе идей развивающего обучения В.В. Давыдова и мыследеятельностной педагогики // Психологическая наука и образование. 2010. № 4.

4. Сазонова З.С. Интеграция образования, науки и производства как методологическое основание подготовки современного инженера: монография. М.: МАДИ (ГТУ). 2007.

5. Собчик Л.Н. Психология индивидуальности. Теория и практика. СПб.: Речь, 2003.

6. Хуторской А.В. Метапредметный подход в обучении. Научно-методическое пособие.

М.: Эйдос, 2012.

(C) 2015, Гуляева В.Н., Евтихиева А.Н., Наумов А.И., Рябикова Л.А., Золотова Т.В., Федоров А.С. Образование и перспективы развития образовательной системы ХХІ века
(C) 2015, Gouliaeva V.N., Evtikhieva A.N., Ryabikova L.A., Naumov A.I., Zolotova T.V., Fedorov A.S.

Education and prospects of development of educational systems of the XXI century 


\title{
Титова A.A. \\ Социологический анализ экономического поведения населения России
}

\author{
Titova A.A. \\ Sociological analysis of economic behavior \\ of the population of Russia
}

В данной статье дан экономический анализ поведения населения Российской Федерации с разбивкой по возрасту

Ключевые слова: экономическое поведение, экономическое сознание, стратегии экономического поведения

\section{Титова Александра Александровна}

Магистрант

Тамбовский государственный технический университет

г. Тамбов, ул. Советская, 106
In this paper an economic analysis of the behavior of the Russian population by age

Key words: economic behavior, economic consciousness, the strategy of economic behavior

\author{
Titova Alexandra Alexandrovna \\ Undergraduate \\ Tambov state technical University \\ Tambov, Sovetskaya st., 106
}

Что имеем - не храним, а, потерявши плачем

Народная мудрость

\section{Введение}

Россия многонациональная страна. У нас проживают и русские, и татары, и украинцы, и чуваши, и белорусы, и немцы, и чеченцы, а также аварцы, армяне, евреи. И молодые, и пожилые, и дети. И у каждого человека свои стремления, свои желания, свои возможности и способности.

В условиях цивилизации наши потребности в вещах и предметах, продуктах и т.д., обеспечивающих нормальные условия жизни, удовлетворяются в основном за счет материального производства. Эта сторона нашей жизни и деятельности выражена в экономическом сознании.

Ежедневно мы бываем в магазинах, на рынках.

Иногда наша жизнь может быть трудной из-за недостатка денег и материальных средств. Иногда у людей много денег, но они все равно несчастливы.

Человек будет несчастен (даже очень богатый человек), если он станет сравнивать себя с другими, более преуспевающими людьми. Но этого можно избежать, если сравнивать себя с менее богатыми людьми. Но это в жизни не главное. 
Одна восточная пословица гласит: «Деньги потерял - ничего не потерял, здоровье потерял - много потерял, честь потерял - все потерял. Лучше бы тебе не родиться». В данном выражении заключен огромный смысл, актуальный для современного общества.

Несмотря на имеющиеся разработки, эта тема еще не получила своего специального анализа.

Объектом исследования данной работы является население России, предметом - экономическое поведение населения России.

В работе ставилась задача рассмотреть экономическое поведение русских людей: взрослых, детей, пожилых, мужчин и женщин. Посмотреть, как тратят деньги различные слои населения, как они относятся к экономике, к деньгам.

\section{Экономика в нашей жизни}

Экономика в жизни каждого человека играет огромную роль. Любой человек каждый день ходит на работу, в магазин за покупками, и т. д.

Под экономикой принято понимать систему общественного производства, процесс создания материальных благ, необходимых человеческому обществу для его нормального существования и развития, а так же науку, изучающую экономические процессы [9].

Роль экономики в жизни всего общества трудно переоценить. Она дает людям все необходимое: жилье, продукты питания, одежду и т.д. Она необходима для развития государства.

Усиливается роль экономических отношений, потому что каждый взрослый человек осознает свою ответственность перед другими людьми и пытается достичь как можно более высокого уровня жизни. Каждый хочет продвигаться по карьерной лестнице, зарабатывать миллионы.

Мы даем деньги в долг, берем кредит, тратим деньги, зарабатываем их и даже не задумываемся о том, насколько это важно.

Некоторые люди берут кредит, например, на покупку холодильника, не думая о количестве денег, переплаченных, «подаренных», так как с детства мы привыкли считать это простой денежной операцией.

С экранов телевизоров, по радио мы слышим о беспроцентных кредитах. Но таких кредитов не существует, само слово кредит подразумевает проценты, которые мы обязуемся заплатить «кредитору».

В нашем мире все завязано на «экономике». Без нее мы просто не смогли бы существовать. У нас было бы натуральное хозяйство, каждый человек сам для себя производил бы продукты, одежду, строил бы себе хижины. Но это очень сложно, поэтому уже в древние времена это поняли и создали сложную систему, которая называется экономика.

Экономика разделяется на 4 типа: традиционную, рыночную, административно-командную и смешанную.

В настоящее время большинство государств придерживается рыночной экономики. Она основана на товарном производстве. Ее существование невозможно без частной собственности, конкуренции, свободных, определяемых рынком, цен. 
Оглянувшись вокруг, мы можем заметить, что наша жизнь состоит из потребностей. Мы постоянно чего-то хотим. Кому-то достаточно того, что у него есть маленькая, уютно обставленная, комната, а кому-то не хватает домаособняка на Канарских островах. Все мы очень разные. И способности у нас разные. Кто-то может купить только старенькие «Жигули», и он этому очень рад. А кто-то не доволен своим новым «Лексусом».

Есть вещи, в которых нуждается один человек или семья, а есть, в которых нуждается все общество. Например, стране нужна система образования, что бы учиться смог каждый гражданин этой страны. Для этого нужны деньги. Это тоже является примером экономики.

Для удовлетворения разнообразных потребностей используют ресурсы. Следует помнить, что они ограничены. Чтобы купить телевизор, нужны деньги. А их нужно заработать.

Все-таки попробуем ответить на вопрос: «Что же такое экономика?».

Существуют различные определения экономики.

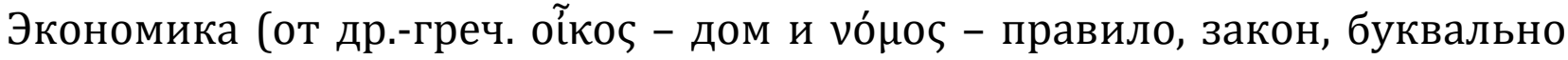
«правила ведения хозяйства») - хозяйственная деятельность общества, а также совокупность отношений, складывающихся в системе производства, распределения, обмена и потребления [8].

Мы удовлетворяем свои потребности при помощи разнообразных товаров и услуг.

Экономика состоит из отраслей, а отрасли из предприятий.

Предприятия производят разнообразную продукцию. Для того, что бы произвести, например, автомобиль необходимо задействовать много людей различных специальностей. Это инженеры-конструкторы, которые проектируют модель автомобиля; рабочие, которые делают различные детали автомобиля; рабочие, которые собирают автомобиль, красят его; люди, которые тестируют автомобиль, и т.д. И это все только для производства одного автомобиля. Разделение труда позволяет каждому работнику делать свою операцию точнее и быстрее.

Современная экономика очень специализированна. Каждый делает чтото одно, а потом обменивает результаты своего труда на результаты труда других людей.

Итак, экономика существует, чтобы удовлетворять наши потребности в разнообразных товарах и услугах.

\section{Экономическое сознание и экономическое поведение}

Экономическое сознание - системная составляющая сознания, высший уровень психического отражения экономических отношений общественно развитым человеком [5].

Экономическое поведение - поведение, связанное с перебором экономических альтернатив с целью рационального выбора, т. е. выбора, в котором минимизируются издержки и максимизируется чистая выгода [4]. 
Предпосылками экономического поведения выступают экономическое сознание, экономическое мышление, экономические интересы, социальные стереотипы.

При этом каждый феномен по-своему формирует тот или иной тип экономического поведения.

Так, например, техника экономического мышления - это некая предпосылка, которой человек руководствуется в своем поведении. Исходя из баланса рациональности и эмоциональности своего мышления индивиды предпринимают лишь те действия, которые принесут им наибольшую чистую пользу.

Общаясь между собой (особенно по поводу потребления и распределения экономических ресурсов) люди преследуют свои интересы и удовлетворяют свои потребности. Это вторая экономическая предпосылка, позволяющая предсказать экономическое поведение.

Люди создают возможность выбора для других людей, действуя в собственных интересах.

Существует несколько стратегий поведения людей:

- стратегия прагматического поведения (достичь материального благополучия, сделать карьеру), данный тип поведения не зависит от возраста, от пола, присущ различным группам;

- стратегия профессионального поведения (получить интересную работу в будущем), связана с уровнем образования человека;

- стратегия безразличного поведения (просто нужно получить образование), данный тип поведения не связан с уровнем образования, полом и возрасTом.

В рамках концепции экономического поведения можно объяснить социальные явления, включая и изменение уровня безработицы, как следствие меняющегося соотношения предполагаемых выгод и издержек. Так, например, уровень безработицы складывается из целого комплекса решений, которые принимаются и теми, кто предлагает свой труд, и теми, кто предъявляет на него спрос.

Очевидно, что все они учитывают ожидаемые выгоды и возможные издержки как результат принятия собственных решений. Различные уровни безработицы среди разных групп населения отражают не только различия в спросе на услуги людей, но и вариации в издержках, с которыми связаны для разных людей поиск, начало или продолжение их работы. Реальное представление о социальных механизмах включения различных категорий населения в рынок труда позволяет государственным органам осуществлять балансирование пассивных и активных мер социальной политики в отношении разных социальных групп в условиях формирующихся рыночных отношений [4].

Рассмотрим теперь экономическое поведение молодежи, взрослых людей и людей пожилого возраста.

Экономическое поведение молодежи

Как показывают результаты социологических опросов, семейный бюджет у 77\% молодых россиян, не перешагнувших 30-летний рубеж, складывает- 
ся из зарплаты по месту работы, у 31\% - из стипендий и пособий; каждый пятый в этой группе (21\%) имеет дополнительные нерегулярные заработки, почти столько же (18\%) пользуются помощью родственников, родителей [11].

По своим финансовым возможностям современные молодые люди опережают представителей других возрастных групп. Так, в конце июля после всех трат свободные деньги остались у 17\% людей до 30 лет - это больше, чем у представителей любого из старших поколений. Причем 10\% молодых оставили свои сбережения в рублях, а 7\% превратили рубли в валюту [11].

Но это не значит, что они зарабатывают больше, чем зрелые люди. Просто большинство молодых людей одиноки, они еще не создали свою семью, поэтому деньги, которые они заработали, они могут потратить только на себя. Да и много ли нужно одному человеку? А вот семейные молодые люди тратят те же суммы уже на себя и своих детей. Да к тому же зачастую молодым людям помогают материально их родители.

Сегодня почти в каждой третьей молодой семье (30\%) есть денежные накопления. Больше чем в половине случаев молодые россияне, имеющие накопления, доверяют их Сбербанку (18\%), в три раза реже (6\%) - другим банкам. Еще 6\% предпочитают хранить свободные средства дома [11].

На какие цели копят деньги молодые россияне? Об этом можно судить по ответам на косвенный вопрос: "ПРЕДПОЛОЖИМ, ЧТО ВЫ (ВАША СЕМЬЯ) РАСПОЛАГАЕТЕ ДЕНЕЖНОЙ СУММОЙ. КАК ВЫ, СКОРЕЕ ВСЕГО, РАСПОРЯДИТЕСЬ ЭТИМИ ДЕНЬГАМИ?" (данные в \% от числа опрошенных моложе 30 лет) [11]:

\begin{tabular}{|l|c|}
\hline Потрачу на приобретение вещей для дома & 42 \\
\hline Отложу, чтобы накопить на дорогие приобретения (дом, квартиру, автомобиль) & 19 \\
\hline Приобрету участок земли, садовый домик & 18 \\
\hline Вложу в собственное дело, предприятие & 13 \\
\hline Потрачу на туристическую поездку, путешествие & 13 \\
\hline
\end{tabular}

Молодежь стремиться занять руководящие места в крупных престижных организациях, получать огромную заработную плату, ничего не делая. Это им необходимо для того, чтобы купить жилье, машину, хорошо одеваться. Так же это способ реализации своих амбиций.

Различается поведение молодежи в зависимости от того, где они проживают. Молодым людям в деревнях и селах платят очень маленькие зарплаты по сравнению со средними заработными платами. В городах заработные платы значительно больше.

Молодые специалисты с трудом устраиваются на работу. А если устраиваются, то получают заработную плату намного меньше, чем работники со стажем. Например, молодые учителя, только закончившие университет и пришедшие работать в школу, получают заработную плату около 3 - 4 тысяч рублей. А учителя, проработавшие в школе более 20 лет, имеют надбавки за выслугу, за классное руководство.

Так же существуют различия в стратегиях экономического поведения у молодежи различных социальных групп. 
Вообще у молодежи постоянно растут потребности в связи с расширением потребительского рынка. Но из-за низкого уровня жизни большей части молодых людей, они не могут удовлетворить свои потребности.

Молодые люди хотят получить все и сразу, но не имеют для этого средств. Молодым семьям негде жить. Поэтому они не хотят заводить детей. В нашем современном обществе молодежь предпочитает сначала сделать карьеру, купить квартиру, машину, а потом только создавать семью.

Будущее страны зависит от того, какие цели перед собой поставят ее молодые граждане, какой путь достижения этих целей они выберут.

Но в нестабильном обществе, каким сейчас является Россия, молодые люди могут строить только кратковременные планы. У нас исчезли идеалы, экономическое поведение сводится к тактике. Люди думают только о сегодняшнем дне.

Происходит имущественное расслоение населения. У людей различные планы, устремления, намерения, ценности.

Экономически выгодно делать инвестиции в молодежь. Она ответственна за сохранение и развитие нашей страны, за преемственность культуры и истории.

Особое значение имеет адекватная молодежная политика со стороны государства.

Необходимо помогать молодежи, нужно предоставлять ей работу, обеспечивать жильем, нормальным питанием. Необходимо позаботится о таких вещах, как бесплатные и своевременные места в детские сады. Нужно обеспечивать молодых людей достойной заработной платой. Следить за тем, что бы люди работали по профессии, а не кассирами в ближайшем магазине.

Но усилия органов государственной власти в регионах Российской Федерации по обеспечению гарантий труда и занятости молодежи, поддержки молодежного предпринимательства остаются недостаточно эффективными [1]. Предпринимаемые меры не успевают за динамично развивающимися социальными процессами.

Экономическое поведение зрелых людей

Изучение экономического образа жизни, экономического сознания личностно зрелых людей дает обществу определенный педагогический идеал экономического развития [2].

Очень важно, как люди относятся к деньгам, какие мотивы у людей, социальные установки, потребности, а так же экономическое мышление и представление.

Отношение к деньгам связано с потребительским поведением.

Существует проблема адаптации к рынку зрелых людей, из-за возникновения различных форм собственности, финансового расслоения общества.

Для одних деньги - это цель жизни, для других - условие существования.

Среднему поколению приходится обеспечивать себя, детей, внуков и пожилых родителей. Молодежь еще не встала на ноги, она учится или только начинает делать карьеру, пожилые уже не в состоянии о себе заботится и им трудно жить на маленькую пенсию. 
Очень мало зрелых людей получают хорошую заработную плату. Так же людям среднего возраста сложно устроится на работу, так как работодателям нужны молодые специалисты со стажем работы. А люди предпенсионного возраста никому не нужны.

По мере развития человека изменяется и его отношение к деньгам. Это можно проследить по потребностям, ценностям, мотивам, социальным установкам и т.д.

Зрелые люди уже не совершат необдуманных трат, они не купят спонтанно очень дорогую шубу, только потому, что она им понравилась. Они подумают о своей семье, о заработках. Они лучше купят на эти же деньги чтонибудь для своих детей.

Мотивы израсходования денег у зрелых людей связаны с самореализацией, творчеством, саморазвитием, помощью другим людям.

Отношение к деньгам показывает, удовлетворен или нет своей работой человек.

С помощью денег люди удовлетворяют материальные, социальные, духовные потребности.

Те люди, у которых уже взрослые самостоятельные дети, могут позволить потратить деньги на что-то интересное. Некоторые ходят по театрам, другие предпочитают ходить на йогу, а третьи совершить кругосветное путешествие, посмотреть другие страны.

А вообще отношение к деньгам в большей степени зависит от индивидуально-психологических особенностей людей, чем от социальных изменений.

Экономическое поведение пожилых людей

У пожилых людей ситуация противоположна ситуации молодежи. У них уже нет ни сил, ни возможностей, например, открыть свой бизнес. Даже кредит им не дадут, потому что у них маленькая пенсия, а также существуют возрастные ограничения. Поэтому пожилые люди вынуждены существовать на очень маленькие пенсии, на пособия государства, на помощь своих детей и родственников.

Обычно людей старших возрастов рассматривают как объект социальной защиты. Считается также, что у них очень сложно проходит трудовая адаптация.

Тема поведения пожилых людей на рынке труда приобретает особую окраску и социальное значение еще и потому, что сейчас, в отличие от 1980-хначала 1990-х годов, на пенсию выходят поколения людей с высоким уровнем образования и более высокими жизненными стандартами [12].

Под экономическим поведением пожилых людей можно рассматривать поведение при получении и распределении доходов.

Люди старшего поколения уходят или остаются на рынке труда из-за следующих факторов [12]:

- Факторы, относящиеся к предложению труда (например, здоровье и предпочтения в отношении времени досуга). 
- Факторы, относящиеся к спросу на труд (издержки найма и обучения, ограничения режимов рабочего времени, дискриминация).

- Институциональные факторы (в первую очередь, особенности действующей в стране системы пенсионного обеспечения).

Необходимо учитывать потери от незанятости пожилых людей, так как рынок труда «не расположен»к работникам в возрасте: предпочтения работодателя более молодым специалистам, сложный поиск работы, сложности в адаптации и т.д.

С данной ситуацией сложно бороться.

Люди в возрасте рассматривают работу в качестве вторичной деятельности. Как правило, продолжительность рабочего времени у них ниже. Все это объясняется особенностями предложения труда для данной группы населения.

Многие пожилые россияне пенсионного возраста могут вполне работать, и они хотят этого. Но работодатели относятся к этому отрицательно.

В большинстве стран продолжительность жизни женщин на несколько лет больше продолжительности жизни мужчин. Женщины нередко имеют в своем распоряжении меньше ресурсов и чаще страдают от болезней, связанных с достижением пожилого возраста. Поэтому необходимо обеспечивать гарантированность дохода и медицинского ухода для женщин. В то же время необходимо расширять исследования, посвященные изучению биомедицинских, социальных и культурных причин значительной разницы в продолжительности жизни женщин и мужчин.

Люди в возрасте имеют более высокий уровень образования, опыт, квалификацию. Использование потенциала старшего поколения необходимо для успешного развития общества. При этом у пожилых людей появиться возможность самореализации.

На фоне демографического старения России возрастает актуальность исследования социальной активности пожилых людей. Особый интерес в этом плане представляет поиск путей активизации их социального поведения в связи с осознанием изменившейся роли пожилых людей, которые в настоящее время стали более активны, деятельны [7].

На данный момент активность пожилых людей состоит из выполнения повседневной домашней работы и свои собственные интересы (хобби). Это способствует позитивной самооценке, позволяют избежать одиночества.

Социальная активность пожилых людей зависит от субъективных (личностных качеств отдельного человека, уровня его образования, его мотивации и жизненной позиции) и объективных (отношения общества к пожилым людям, от совершенствования социального управления, согласования интересов и действий различных социальных институтов) факторов. Определяя причины активности пожилых людей, следует иметь в виду объективную необходимость поддержания, выполнения определенной роли каждым человеком в обществе в процессе его жизни, удовлетворения потребностей поддержания его жизнеобеспечения и деятельного существования [3]. 
Необходимо отметить, что статус пожилого человека в современном обществе зависит от таких факторов, как семейное положение, место проживания, доходы, уровень образования и т.д.

А прекращение трудовой деятельности, маленькие пенсии, отсутствие других доходов и большие расходы на ЖКХ являются причинами снижения социально-экономического статуса.

В современном российском обществе социальный статус пожилых людей является низким.

Важнейшим параметром, характеризующим уровень жизни пожилого человека, является уровень его доходов и, прежде всего, размер пенсии, соотнесенный с уровнем цен на потребительские товары и услуги, отвечающие представлениям о социально признанных стандартах потребления. Система важнейших оперативных индикаторов уровня жизни пожилого человека включает в себя следующие показатели: величина прожиточного минимума; средняя пенсия; покупательная способность пенсий [6].

В современном обществе существует стереотип старости. Старость представляется как немощность, бесполезность. Данное мнение широко распространено и негативно влияет в первую очередь именно на пожилых людей, определяет их отношение к жизни, к возможностям и способностям.

Необходимо формировать позитивный имидж старости. Нужно помнить, что пожилые люди являются квалификационным и культурным потенциалом. Это необходимо ценить. Еще мыслители древности (Платон, Аристотель, Конфуций) [6] считали, что для принятия важных решений в управлении государством незаменимы люди, прошедшие длительный жизненный путь, наделенные опытом и мудростью.

\section{Заключение}

Экономическое сознание людей является важной формой общественного сознания. Оно проявляется через отношение людей к экономическим процессам и явлениям.

Экономическое сознание появилось из-за потребности осмысления экономики, экономических моделей, политики, самостоятельности и т.д.

Экономическое сознание общества отражает понимание экономической деятельности, соотношения между ней и политико-правовыми условиями.

Экономическое сознание формируется под влиянием конкретных исторических условий. Оно определяется необходимостью осмысления происходящих социально-экономических изменений.

Современное развитие российского общества, характеризующееся экономической нестабильностью, несоответствием уровня интенсивности социальных, политических, духовных изменений возможностям людей адаптироваться к ним, определяет постановку и решение проблемы развития экономического сознания как одного из значимых направлений социальнопсихологической науки [10]. 


\section{Список литературы:}

1. Максименко А.А.Стратегии экономического поведения молодежи регионов России: политикопсихологический аспект. Автореферат на соискание степени д. п. н.

URL: http://www.dissercat.com/content/strategii-ekonomicheskogo-povedeniya-molodezhi-regionov-rossiipolitiko-psikhologicheskii-as

2. Семенов М. Монетарные отношения личностно зрелых людей как педагогический идеал.

URL: http://www.b17.ru/article/7404/

3. Социальная активность пожилых людей в современном российском обществе.

URL: http://referat.yabotanik.ru/sociologiya/socialnaya-aktivnost-pozhilyh-ljudej-v-

sovremennom/216195/203070/page2.html

4. Социология труда и экономическая социология.

URL: http://www.bestreferat.ru/referat-197683.html

5. Человек в экономике.

URL: http://bookap.info/genpsy/krylov_psihologiya/gl181.shtm

6. Щанина Е.В. Социальная активность пожилых людей в современном российском обществе:региональный аспект. Автореферат на соискание степени д.с.н.

URL: http://www.dissercat.com/content/sotsialnaya-aktivnost-pozhilykh-lyudei-v-sovremennom-rossiiskomobshchestve-regionalnyi-aspe

7. Щанина Е.В. Факторы социальной активности старшего поколения // Известия высших учебных заведений. Поволжский регион. № 2 (10). 2009. С. 57-67.

8. Экономика. Википедия.

URL: http://ru.wikipedia.org/wiki/\%D0\%AD\%D0\%BA\%D0\%BE\%D0\%BD\%D0\%BE\%D0\%BC\%D0\%B8\%D0\% $B A \% D 0 \% B 0$

9. Экономика и ее роль в жизни общества.

URL: http://humanitar.ru/page/bilet_number10

10. Экономическое сознание в России.

URL: http://otherreferats.allbest.ru/sociology/00066967_0.html

11. Экономическое поведение молодых россиян. База данных ФОМ.

URL: http://bd.fom.ru/report/cat/social_group/molodezh/of19973303

12. Экономическое поведение пожилого населения России.

URL: http://www.hse.ru/org/projects/13315057/

(C) 2015, Титова A.A.

Социологический анализ экономического поведения населения России
(C) 2015, Titova A.A.

Sociological analysis of economic behavior of the population of Russia 
DOI: $10.17117 /$ na.2015.05.225

Поступило в редакцию: 08.05.2015

\title{
Ивлев В.Ю. \\ Особенности нашей памяти
}

\author{
Ivlev V.Yu. \\ Features of our memory
}

В данной статье рассмотрены вопросы памяти Ключевые слова: память, особенности памяти, водитель

\section{Ивлев Виктор Юрьевич}

Магистрант

Тамбовский государственный технический университет

г. Тамбов, ул. Советская, 106
This article considers the issues of memory

Key words: memory, features memory, driver

\author{
Ivlev Viktor Yurevich \\ Undergraduate \\ Tambov state technical university \\ Tambov, Sovetskaya st., 106
}

В нашей жизни память выступает как способность, которая отличается характеристиками, индивидуальными для каждого.

На протяжении жизни изменяется способность к запоминанию, также память различается и в зависимости от ситуаций. Это происходит, потому что память, выступая умственной деятельностью человека, на протяжении всей жизни изменяется вместе с ним.

Основными проявлениями памяти выступают сохранение, воспроизведение и закрепление информации. Мы с помощью данной способности постоянно пополняем свои знания и используем их при необходимости.

У разных людей интенсивность запоминания различается, так как память каждого человека является особенной. Одним для запоминания необходимо приложить огромные усилия, другим, наоборот, не представляется это сложной задачей. Необходимо учесть, что разные вещи мы запоминаем по-разному. Например, одни хорошо помнят имена и лица людей, но в повседневной обстановке не могут вспомнить, где находиться какая-либо вещь [3, с. 74]. Другие, наоборот, прекрасно помнят, куда положили ту или иную вещь, а имя сослуживца, с которым проработали долгое время, вспомнить не могут. Для кого-то основной выступает слуховая и музыкальная память, для кого-то - зрительные образы, некоторые хорошо запоминают тактильные ощущения [6, с. 115].

Зависит качество памяти от следующих обстоятельств:

- среды воспитания;

- индивидуальных особенностей нервной системы;

- видов деятельности и способов обучения человека. 
Совершенствуются в основном виды памяти, задействующиеся чаще всего. Зачастую, связано это с профессиональной деятельностью: у научных сотрудников замечательная логическая и смысловая память, у администраторов прекрасная память на лица и имена, актеры без трудностей запоминают эмоции и тексты.

Ребенок для запоминания пользуется различными словами, жестами, рисунками, предметами; постепенно взрослея, он «переходит» на логические связи, чувства, мысли, образы. Постепенно речь из внешней функции общения превращается во внутреннюю [3, с. 74].

В основании памяти находятся ассоциации. Связанные явления или предметы, и в нашей памяти связываются. К примеру, увидев один предмет, по ассоциации человек вспоминает связанный с ним другой предмет. Что-то запомнить означает создать ассоциацию того, что необходимо запомнить с тем, уже известным [5, с. 49].

Особенность совершенствования памяти заключается в том, что подбирая необходимые методы, ей можно управлять. Запоминание называется произвольным тогда, когда имеется осознанная цель выучить материал. Для заучивания в данном случае используют специальные приемы - составление схем, плана, выделение главных мыслейи т.п. и прилагают силу воли.

Осмысленное запоминание основывается между частями изучаемого материала на установлении смысловых связей. Определенные части обобщаются и анализируются - это запоминание является более быстрым и прочным. Если такого запоминания недостаточно, то материал неоднократно повторяют после того, как он понятен - нельзя в обучении полностью обойтись без механического запоминания.

Также на успешное запоминание оказывают влияние цели, которые стоят пред человеком. Например, если необходимо точное в последовательности воспроизведение, то необходимо установить логику и смысловые связи материала; если необходимо воспроизвести точно текст, то нужно повторять отдельные слова и фразы [1, с. 192].

Следующей особенностью совершенствования памяти выступает настрой на прочность запоминания. Если у человека отсутствует намерение точно освоить материал, то последний выучивается по мере необходимости и также быстро забывается. Во избежание такого, необходимо приучаться к проверке прежних знаний вовремя изучения нового материала.

Вид памяти рассматривается как любая информация, запоминающаяся нами. Так как каждый запоминает все: и движения, и образы, и чувства, и мысли, то разные виды характерны всем людям, при этом не составляют какой-то определенной особенности памяти, свойственной определенному человеку.

Типом памяти больше всего выделяется способ запоминания: на слух, зрительно, либо двигательно. Таким образом, тип памяти, преобладающий при запоминании, выступает характерной особенностью памяти, свойственной для определенного человека.

От деятельности сохранения материала различают кратковременную, мгновенную, долговременную, оперативную, а также генетическую память. 
Иконическая (мгновенная) память выступает непосредственным отражением образа информации, который воспринят органом чувств. Кратковременная память в течение небольшого промежутка времени сохраняет более значимые элементы воспринятой информации, ее обобщенный образ. Составляет объем такой памяти около 8 единиц информации и определяется по информации, способной после однократного воспроизведения точно воспроизводиться человеком. Главная особенность кратковременной памяти заключается в ее избирательности. Попадает в нее из иконической памяти лишь информация, соответствующая актуальным интересам и потребностям человека, привлекающая к себе его особое внимание. По мнению Эдисона, мозг человека не воспринимает даже тысячной доли тех событий, которые видят глаза [10, с. 41]. Оперативная память рассчитывается на сохранность информации в течение заранее заданного, конкретного срока, который требуется для совершения какойлибо операции или действия. Долговременная память в течение неограниченного срока может хранить информацию, притом имеется возможность ее неоднократного повторения. Функционирование долговременной памяти на практике обычно связывают с волевыми усилиями и мышлением. Заключительная - генетическая память объясняется генотипом и передается из поколения в поколение. Понятно, что воздействие на такой вид памяти человека совершенно ограничено.

В зависимости от преобладающего анализатора в процессе функционирования памяти выделяются зрительная, двигательная, осязательная, слуховая, вкусовая, обонятельная, эмоциональная и иные разновидности памяти.

Преобладающим видом памяти у человека выступает зрительное восприятие. К примеру, зачастую мы знаем человека в лицо, но его имя вспомнить не можем. За воспроизведение и сохранение зрительных образов ответственность несет зрительная память. Напрямую она связана с развивающимся воображением: то, что зрительно человек может себе представить, как правило, он проще запоминает и воспроизводит [4, с. 68].

Слуховая память является хорошим запоминанием и точным воспроизведением различных звуков, к примеру, речевых, музыкальных. Особенной разновидностью речевой памяти выступает словесно-логическая память, связанная тесным образом со словом, логикой и мыслью. Двигательная память выступает запоминанием и сохранением, и воспроизведением, при необходимости, с определенной точностью сложных разнообразных движений. Двигательная память участвует в создании двигательных навыков и умений. Явный пример двигательной памяти - рукописное воспроизведение текста, которое, как правило, подразумевает автоматическое написание символов, когда-то изученных [9, с. 17]. Эмоциональной памятью считается память о переживаниях. Эмоциональная память участвует в работе всех видов памяти, но в особенности проявляется в человеческих взаимоотношениях. На эмоциональной памяти основывается прочность запоминания материала: то, что вызывает у человека эмоции, запоминается на более долгий срок и без особых усилий. 
В сравнении со слуховой, зрительной, эмоциональной, двигательной памятью возможности обонятельной, осязательной, вкусовой и иных видов памяти не играют в жизни человека особой роли, так как они очень ограничены.

Всем людям характерны разновидности памяти, но преимущественный тип является особенностью каждого в отдельности. Есть люди с различными типами памяти. Одним достаточно услышать термин либо новое название, другим необходимо произнести его, третьим - зарисовать или записать сложившиеся ассоциации. Зная о своих индивидуальных особенностях запоминания, мы можем осваивать приемы, которые компенсируют слабые стороны нашей памяти [7, с. 325].

Вышеперечисленные виды памяти только характеризуют источники исходной информации и в чистом виде в памяти не хранятся. В процессе воспроизведения (запоминания) информация претерпевает различные изменения: отбор, сортировку, кодирование, обобщение, синтез, иные виды обработки информации.

В процессе запоминания и воспроизведения материала по характеру участия воли память разделяют на произвольную и непроизвольную.

Перед человеком при произвольной памяти стоит специальная мнемоническая задача (на узнавание, запоминание, воспроизведение, сохранение), которая осуществляется при помощи волевых усилий. Непроизвольная память функционирует без особых на то со стороны человека усилий, автоматически [2, с. 128]. Непроизвольное запоминание не обязательно является наиболее слабым, чем произвольное, во многих случаях жизни оно его превосходит.

Для водителей память играет огромную роль. Данная профессия обязывает знать Правила дорожного движения. Также водителю приходиться запоминать маршруты движения, обстановку вокруг себя и т.д. Все эти навыки водителю приходиться использовать в условиях повышенных перегрузок. Поэтому водителям должны быть присущи следующие свойства памяти: скорость запоминания, точность, продолжительность; достаточный объем памяти. Водитель должен уметь быстро усваивать, сохранять и воспроизводить информацию. Для водителей важны все виды памяти (слуховая, двигательная, зрительная). Очень важен опыт водителя (долгосрочная память), также незаменимой является способность запоминать большой объем информации за короткий срок (кратковременная память), что является неотъемлемой частью системы ВАДС.

Необходимо учитывать, что одним из свойств памяти является забывание (быстрее забывается та информация, которую долгое время не используют). Для исключения этого эффекта (особенно важно для водителей) необходимо периодическое повторение теоретического материала (Правила дорожного движения) и практических навыков (автомобильные тренажеры, автодромы, автомобильные площадки).

Принадлежность к конкретному типу в большей степени диктуется тем, что определенно приходится человеку запоминать, а также каким образом он привыкает запоминать. Водители используют все виды памяти. Таким образом, соответствующий тип памяти значительно можно усовершенствовать при 
помощи определенных упражнений. Сама по себе память развиваться не может. Ее необходимо «воспитывать».

В большей степени этому способствует совершенствование практической и мыслительной деятельности человека: самоконтроль, планирование, оптимизация методов запоминания, порядок на рабочем месте, трезвая критика к результатам своей деятельности, синтез практической и умственной активности, умение отказаться от неэффективных рабочих приемов и т.д.

Совершенствование памяти происходит в процессе обучения и выступает как результат запаса знаний, совершенствования отвлеченного мышления, самосознания и воли, т.е. личности в целом [8, с. 32]. Формируется личность на протяжении всей человеческой жизни, соответственно, вместе с ней формируется и память.

Знание главных особенностей совершенствования памяти помогает достигнуть отличных результатов тем, кто желает улучшить свои интеллектуальные способности.

\section{Список литературы:}

1. Андреев О.В. Техника развития памяти. М.: Омега-Л, 2012. 320 с.

2. Аткинсон У.У. Память и ее развитие. М.: Студия АРДИС, 2013. 340 с.

3. Букин Д. Развитие памяти. М.: Альпина Паблишер, 2015. 456 с.

4. Гуревич П.С. Психология. М.: КноРус, 2015. 208 с.

5. Кавашима Рюта Японская система развития интеллекта и памяти. Спб.: Питер, 2014. 192 с.

6. Лорейн Гарри Развитие памяти. Классическое руководство по улучшению памяти. М.: Манн, Иванов и Фербер, 2014. 256 c.

7. Маклаков А.Г. Общая психология. Спб.: Питер, 2013. 592 c.

8. Столяренко Л.Д., Столяренко В.Е. Психология. М.: Юрайт, 2015. 176 с.

9. Терентьева Н.В. Память и внимание: Монография. М.: Стрекоза, 2011. 32 c.

10. Фрай Рон Треннировка памяти: Экспресс-курс. М.: Альпина Паблишебер, 2014. 148 c.

\section{References:}

1. Andreev O.V. Technique of memory: Tutorial. M.: Omega-L, 2012. 320 p.

2. Atkinson W.W. Memory and its development. M.: Studio ARDIS, 2013. 340 p.

3. Bukin D. memory Development. M.: Alpina Pablisher, 2015. 456 p.

4. Gurevich P.S. Psychology: textbook. M.: KnoRus, 2015. 208 p.

5. Kawashima, Ryuta Japanese system of development of intelligence and memory: Curriculum. SPb.: Peter, 2014. $192 p$.

6. Lorraine Harry the memory. The classic guide to improving your memory. M.: Mann, Ivanov and Ferber, 2014. $256 \mathrm{p}$.

7. Maklakov A.G. General psychology: Textbook. SPb.: Peter, 2013. 592 p.

8. Stolyarenko L.D., Stolyarenko V.E. Psychology. M.: Yurait, 2015. 176 p.

9. Terentieva N.I. Memory and attention: Monograph. M.: Dragonfly, 2011. 32 p.

10. Fry Ron Workout memory: Express course. M.: Alpina Pablisher, 2014. 148 p.

(C) 2015, Ивлев В.Ю.

Особенности нашей памяти
(C) 2015, Ivlev V.Yu.

Features of our memory 


\title{
Воронин В.C. \\ Суггестия, контрсуггестия и законы фантазии в прозе А.П. Чехова
}

\author{
Voronin V.S. \\ Suggestion, kontrsuggestion and laws of \\ fantasy A.P. Chekhov`s prose
}

Данная статья посвящена отражению в прозе Чехова таких явлений жизни общества и индивида, как суггестия и контрсуггестия. Эти

характеристики социальной психологии в мире Чехова оказываются самым тесным образом связаны с законами фантазии

Ключевые слова: суггестия, контрсуггестия, законы фантазии, фильтр недоверия

\section{Воронин Владимир Сергеевич}

Доктор филологических наук, профессор

Волжский гуманитарный институт (филиал) Вол ГУ

2. Волжский, ул. 40 летия Победы, 11
This article is devoted to reflection in Chekhov's prose of such phenomena of society and the individual, as a suggestion and kontrsuggestiya. These characteristics of social psychology in Chekhov's world are most closely associated with the laws of fantasy

Key words: suggestion, kontrsuggestiya, the laws of fantasy, filter distrust

\section{Voronin Vladimir Sergeevich}

Doctor of Philological Sciences, Professor

Volzhsky Humanitarian Institute (branch) VSU

Volzhsky, 40 let Pobedy st., 11

Исследованием роли суггестии и контрсуггестии (внушения и контрвнушения) в истории человечества плодотворно занимался своеобразный и, быть может, исключительно своеобразный, советский историк и философ Б.Ф. Поршнев. В обыденной практике при внушении чего-либо люди далеко не всегда прибегают только к научным аргументам, а апеллируют к фантазии и воображению собеседника. Фантазия в самом общем плане есть способность человека превращать в своём воображении некоторый объект А в объект Б. При этом нужно помнить, что и отражение реальности тоже в огромной мере идёт таким образом, что некоторое А объясняется через ряд других понятий и предметов. Однако реальное отражение вещей и явлений оставляет возможность возвращения к изначальному пункту познания, сверки отражения и оригинала, тогда как фантазию это не беспокоит. Она обращается к внушению без проверки и, попав на подходящую почву в человеческом сознании, способна ложь превращать в истину и обращать истину в ложь. Вводя простейшее подразделение на объекты и признаки, можно выделить следующие формулы преобразования мира в художественной реальности: 1. Сращивание признаков различных объектов; 2. Умножение и разделение объектов; 3. Установление реально не существующей связи между объектами; 4. Превращение части в целое, признака в объект и обратно; распад целого на части; замещение объекта 
его признаками; 5. Исчезновение и возникновение объекта [1, с. 6 - 7; 4, с. 207]. По мнению Б.Ф. Поршнева, в своём чистом виде суггестия принадлежит едва ли не к самым ранним этапам становления человеческого общества, но ее проявления достаточно живы и в современном обществе, как неустранимое наследие предков она продолжает жить в культуре и литературе, в общественной идеологии и психологии. Можно предположить, что сращивание признаков животного и человеческого в поведении людей несёт следы этой предковой формы внушения. Однако с течением времени общество и вместе с ним индивид вырабатывают средства защиты от тотального внушения. Возникает, по терминологии Б.Ф. Поршнева, «фильтр недоверия», постулаты веры и безоговорочные аксиомы общественного бытия пересматриваются: «канал информации может быть блокирован явлением недоверия, которое в свою очередь, очевидно, может быть объяснено только тем, что приём информации без этого задерживающего устройства в пределе приносит принимающему вред» [3, с. 9]. Слом фильтра недоверия к обвиняемым - профессиональная задача адвоката. В «Случае из судебной практики» и нарисован такой профессионал, оказывающий умноженное кумулятивное воздействие на всех окружающих. Его язык «заиграл на нервах, как на балалайке», прослезился судебный пристав, «все полезли за платками», и сам прокурор «этот лёд, бесчувственнейший из организмов», подумал о том, что ему было бы лучше «отказаться от обвинения» [7, 2, с. 86 - 87]. Он как бы проходит быструю эволюцию от неорганического льда и лишённого чувств организма до сочувствующего человека. Однако предел достигнут и вполне перейдён в подсудимом. Ради собственной пользы ему следовало бы молчать. Но он плачет и признаёт свою вину, в результате чего его и осудили. Практические цели адвоката и его подзащитного оказались сметены мощной суггестией приобщения виновного к людям нравственным и даже идеальным. А идеал не может себе позволить ни малейшего пятнышка.

В «Сильных ощущениях» суггестия превращает влюблённого в марионетку адвоката. Тот сначала расписывает красоту избранницы, начиная от ресниц и мизинчика. Жених находится на верху блаженства, но тем самым снимается фильтр недоверия, и адвокат получает возможность убедить его в отрицательных последствиях женитьбы. Убеждаемый человек становится полем чистой суггестии, он полностью разделяет взгляды своего советчика: «я возмущался, негодовал, презирал с ним вместе» [7, 5, с. 111]. В конечном счёте, жених пишет невесте письмо, в котором он отказывается от брака с нею. Тут же адвокат заговаривает о прелестях семейной жизни, и молодой человек снова чувствует любовь и готов застрелиться от отчаяния, что потерял настоящее сокровище. Впрочем, потеря оказывается мнимой. Заметим, что адвокат убеждён во всемогуществе слова, творящего историю людей. Он охотно прибегает к фантазии: «Талант - это стихийная сила, это ураган, способный обращать в пыль даже камни, а не то, что такой пустяк, как убеждения мещан и купцов второй гильдии» [7, 5, с.109]. Но в рассказ о силе слова вмешивается сила обстоятельств. Она становится контрсуггестией, призванной обнаружить абсурд в суггестии на уровне её законов фантазии. Один из присяжных заседателей обращается к слушателям подумать о том, что должен в эту ночь перед огла- 
шением приговора чувствовать преступник, и рассказы о сильных ощущениях перестают занимать собеседников.

Любопытен в смысле взаимодействия суггестии и контрсуггестии почти чисто юмористический рассказ А.П. Чехова «Пересолил». Возникновение страха у землемера Смирнова писатель подчёркивает пространственно-временными деталями. Отъездом со станции Гнилушки, состоявшимся в сумерки, поездкой по равнине «без конца и краю... Поедешь по ней, так наверно заедешь к чёрту на кулички» [7, 4, с. 214]. Как видим, протяженность поездки, в самом начале рассказа более или менее определённая в своих границах, полностью утрачивает свою определённость. Протяжённость превращается в бесконечность, упирающуюся в инфернальный мир, пусть и выраженный фразеологическим оборотом. Фантастически возрастает и силища возницы: «пальцем тронет, так душа вон! И морда у него зверская, подозрительная» [Там же]. Заметим, что Клим зоологизируется своим пассажиром. Землемер пытается завязать разговор, успокоить свои страхи. И возница Клим сообщает ему вполне достоверную информацию, что шалить у них некому. Но это информация не в силах успокоить страхи Смирнова. Первоначальное недоверие только усиливается. И он начинает выдумывать себя, отвечая воображаемой угрозе. Он сообщает, что у него три револьвера, и прибегает к зоологизации самого себя: «а силы у меня, словно у быка». Он умножает свои победы. Противника его ждёт полный распад на части: «Не то что без рук, без ног останется, но ещё и перед судом ответит» [7, 4, с. 215]. Он до предела увеличивает число своих союзников в возможной схватке с разбойниками: «Везде по дороге за кустиками урядники да сотские понатыканы» [Там же]. Но страх землемера так велик, что собственная фантазия не может его успокоить. Мощным катализатором страха становится дорога, свернувшая в лес, и то, что лошадь, прежде еле переставлявшая ноги, движется очень быстро. Сообщение Клима о том, что такова особенность его лошади в расчёт не принимается. Кстати, об этой особенности возница сообщил в самом начале поездки, но всё это отброшено и улетучилось из головы объятого страхом пассажира. Принимается во внимание только то, что отвечает его подозрениям и страхам, и вот он выдумывает ещё четырёх товарищей с револьверами, которые и должны настичь их в лесу. Но беда заключается в том, что извозчик к пугающей информации относится с полным доверием, понимает, что он находится во власти опасного человека и бежит, как ему кажется, спасая жизнь, жертвуя телегой и лошадью. Только спустя время к людям, разделённым страхом, на помощь приходят рациональные доводы. Землемер признаётся, что «от страха врал», а Клим понял, что «настоящий разбойник давно бы уж исчез с лошадью и телегой» [7, 4, с. 216]. Взаимный миф о соседе разбойнике рушится. Можно сказать, что и Смирнова и Клима объединяет теперь и пережитый ими обоими страх, который возница, в отличие от землемера, ничуть не скрывает: «Чуть я не помер от страха» [Там же].

В ходе человеческой истории множество внешних сил обрушивается на внутренний мир личности. Они пытаются сломить её внутреннюю контрсуггестию, сделать её открытым полем для внешней суггестии. Со временем это становится сделать всё труднее. Поэтому внешней силе, государству, автори- 
тету, лидеру приходится обнаружить свою родственность индивиду, показать, что они все действуют в его интересах, и сотрудничество с ними в его интересах. Иначе говоря, между убеждающим и убеждаемым должно находиться поле общности. Если такое поле общности есть, то оно способно быть действенной силой в изменении первоначальных взглядов человека, его симпатий и антипатий. Так происходит, например, в рассказе Чехова «Он понял!». Казалось бы, между подполковником Волчковым и мужичком Павлом Хромым, застрелившим в его имении скворца, очень мало общего. Сама по себе вина Хромого незначительна. Но Волчков искренне желает разъяснить горе- охотнику, какой он злодей с точки зрения юридической и христианской. Павел вину признаёт, но отрицает, что делал это из корысти. Его, оказывается, «попутал нечистый». Разумеется, барин ему не верит: «Сам ты нечистого попутать можешь! Все вы, кашиловские, разбойники!» [7, 2, с.172]. Мы видим активное неприятие образа обвиняемого. Барин заранее закрыт для понимания собеседника, убеждён, что тот «ничего умного не скажет» [7, 2, с. 173]. Но мужик детально описывает свою тоску, ставшую для него почти наваждением. «Слышно мне, как какой-то тоненький, словно как будто ангельский, голосочек звенит тебе в ухе и рассказывает: поди, Пашка, постреляй!» [7, 2, с. 174]. Таким образом, человек как бы раздваивается, его страсть к охоте приобретает самостоятельное значение. Это своего рода болезнь, как и тяга к алкоголю. И взявший на себя роль судьи подполковник понимает его «по опыту». Разбойник, виновный, мужик становится просто человеком, подверженным почти той же болезни, что и его судья. Из убеждающего подполковник превратился в убеждаемого человека, проникся сочувствием к мужику и освободил его. Взаимодействие внушения и контрвнушения представляет собой один из интереснейших моментов в изображении психологических типов в прозе раннего Чехова. И.Н. Сухих, говоря о «специфике чеховского мышления» заметил: «Исходным зерном замысла оказывается у него не лицо, характер (как у Толстого), не идея (как у Достоевского) а ситуация, которая может быть «проиграна» на разном персонажном материале» [6, с. 56]. Внутренняя убеждённость персонажа, декларируемая им с той или иной степенью настойчивости, меняется на противоположную, не только сталкиваясь с общественной иерархией смыслов, психологическим или физическим насилием, а в значительной мере под действием ситуации и общения с ближайшим окружением. Очень показателен в этом отношении рассказ «Двое в одном». Автор намеренно заостряет противоречивость человеческой натуры с точки зрения начальника, узнающего и одновременно не узнающего своего подчиненного. По его словам, он «даже и животных таких не знает, которые были бы тише его» [7, 2, с. 9]. Но робкий чиновник вне службы преображается в человека со своими взглядами, заявляющего, что никому не позволит «посягать на свою свободу» [7, 2, с. 10]. Его внутренняя убеждённость в своей правоте так велика, что он обсуждает и мировую политику, и критикует освещение в вагоне конки, требует, чтобы все подвинулись и уступили место женщине. У этого оратора есть умение заинтересовать аудиторию, ибо «его слушал весь вагон» [7, 2, с. 10]. Он сам источник такой сильнейшей суггестии, что заставляет даже начальника сомневаться в том, что перед ним его покладистый 
и покорный подчинённый. Но стоило руководящему лицу рассмеяться, как задиристый герой моментально возвращается в свой прежний пришибленный вид. Именно смех, а не прямой гнев, как в «Смерти чиновника», становится здесь источником контрсуггестии. Но при ближайшем рассмотрении оказывается, что и сам рассказчик, именующий себя «лицом высокопоставленным», двойственный человек. Ездить на конке ему не полагается, но так дешевле. Он тоже среди «сих малых» прячет лицо в воротник, соответствуя среде. И поэтому сам не в меньшей мере хамелеон, чем его подчинённый. Мимикрия оказывается общим полем жизнедеятельности, соединяющей и жалкого чиновника, и его начальника. Последний тоже получает свой удар контрвнушения: «В наше время легче потерять веру, чем старую перчатку, - и я потерял» [7, 2, с. 9].

Чехов считал, что вдохновение и рационализм в реализации авторского замысла должны составлять единое целое, некоторый гармонический синтез. По его словам, «если бы какой-нибудь автор похвастал мне, что он написал повесть без заранее обдуманного намерения, а только по вдохновению, то я назвал бы его сумасшедшим» [2, с. 322]. Многие его персонажи обдумывают свои предстоящие действия, но выполняют их с такой маниакальной настойчивостью, что впадают в ненормальное психологическое состояние, полностью открытое внешней суггестии. Таков маленький человек из знаменитой «Смерти чиновника». Задумав во что бы то ни стало получить полное прощение за то, что нечаянно чихнул на лысину начальника, Червяков многократно обращается к пострадавшему со своими извинениями. Прощение он получает сразу же, но оно ему кажется неполным, и он делает всё новые и новые попытки вежливого извинения. Смех здесь выступает в роли скрытого контрсуггестора, воздействующего на значительное лицо. Ему показалось, что Червяков иронизирует над ним, преследует его Бог весть с какой целью. Общего поля взаимодействия между ними нет. Генерал пытается избежать столкновения, укрыться: «Да вы просто смеётесь, милостисдарь! - сказал он, скрываясь за дверью» $[7,2$, c. 166]. И отчасти генерал сам становится жертвой, хотя и закрыт от суггестии со стороны подчинённых своим официальным статусом. Такой закрытости от начальства подчинённый не имеет, и генеральское «пошёл вон!» буквально вычеркивает Червякова из жизни, персонаж как бы полностью «выходит вон», отвечая требованию генерала. Однако и сам начальник, удаляя назойливого посетителя, посинел и затрясся. На старости лет он тоже получил сильнейший ответный удар от собственного непонимания.

А.П. Чехов, заметил, что «весь смысл и вся драма человека внутри, а не во внешних проявлениях» [2, с. 326]. Сложный узор вышивает взаимодействие суггестии и контрсуггестии даже в его простых по проблематике рассказах. Обратимся к «Торжеству победителя», где достигший высот чиновничьего благополучия Козулин делится своими соображениями о пройденном пути, а приглашённые к нему на званый обед подчинённые внимают каждому его слову. С одной стороны, всё очень просто и почти сводится к грубой пословице: «Я - начальник, ты - дурак, ты - начальник - я дурак». Понятно, начальник выступает в роли высшего авторитета, и фильтр недоверия почти снят. Но не совсем. Отставной коллежский регистратор, от чьего имени ведётся рассказ, даёт 
двойственную оценку «победителю»: «Козулина вы не знаете; для вас, быть может, он ничтожество, нуль, для нашего же брата, не парящего высоко под небесами, он велик, всемогущ, высокомудр» [7, 2, с. 68]. Как видим, рассказчик соотносит две оценки в зависимости от точки зрения: полный нуль за пределами своего круга наделяется всемогуществом - атрибутом Бога - внутри своей группы. И мы видим, что его слово для участников пира наделено высшей властью, ему беспрекословно внимают и повинуются. Но, при всём своём самодурстве, начальник далёк от признания свой собственной исключительности. Каждый может достигнуть того же или даже превзойти его. Интуитивно им нащупывается верный путь слома возможного пререкания и неподчинения. Он подчеркивает своё родство с собравшимися, заражает их этой общностью и истолковывает это к своей выгоде: «Не ропщите, не сетуйте и вы, покуда до конца не доживёте! <...> Ты теперь, положим, ничтожество, нуль, соринка... изюминка - а кто знает? Может быть, со временем и того... судьбы человеческие за вихор возьмёшь» [7, 2, с. 69]. Мы видим, что он неумеренно возвышает всех собравшихся к нему на домашнее торжество и зовёт их к очевидным выводам. Перетерпи унижение, и всё может измениться. Не отчаивайся до последнего часа. Психологическому сближению со слушателями служит и рассказ Козулина о невероятно трудном и унизительном начале собственной карьеры. В качестве его громовержца оказывается присутствующий тут же смиренный старичок Курицын, некогда повелевавший теперешним начальником. Недоброе слово Курицына имело такую абсолютную власть, что буквально свело в могилу мать подчиненного. Как поясняет сам Козулин: «Теперь-то он червячком глядит, убогеньким, а прежде что было! Нептун! Небеса разверзеся!» [7, 2, с. 69 - 70]. Таким образом, к тому моменту, как Козулин начнёт откровенно унижать собравшихся гостей, они уже подготовлены к этому примером начальника, который всё претерпел, возвысился и теперь может заставить их выделывать всё, что ему угодно. Сначала он идеологически сорвал их возможную контрсуггестию. И не унижение вовсе они испытывают у него, а всего лишь проходят низший зоологический круг карьеры, впереди - восхождение. Поэтому-то, бегая вслед за папашей вокруг стола и крича петушком, рассказчик нимало не смущался: «Я бегал и думал: «Быть мне помощником письмоводителя» [7, 2, с. 71].

Устранение препятствий и недомолвок в общении, делает людей открытым полем суггестии друг для друга. Поэтому самые близкие люди и приносят нам как наибольшие радости, так и наибольшие огорчения. Прекрасной иллюстрацией данного процесса является чеховский рассказ «0 том, как я в законный брак вступил». Повествование начинается с того, что молодой человек не понимает, как можно объясняться в любви нелюбимой. Папаша же сразу обобщает степень непонимания своего питомца. Оказывается, сын в своём собственном предстоящем браке - постороннее лицо: «Не твоё дело... Ты, дурак, ничего не понимаешь» [7, 2, с. 153]. Ничего не понимая, жених играет навязанную роль, произносит затверженное признание, девушка говорит, что любит его. Но герой «помертвел от этого её слова», он так надеялся на отказ, поскольку знал, что она любит другого. И в действие вступает иррациональное начало. Жених начинает говорить «сам не зная, что говорит»: «Не люблю я вас! Будь я 
трижды анафема проклят, ежели люблю! И вы меня не любите!» [7, 2, с. 154]. Навязанный родителями сценарий сорван. И вот уже жених и невеста откровенно признаются, что не любят друг друга, имеют другие сердечные привязанности и вступают в брак по воле родителей, «ради имущественных интересов» [Там же]. Жених немедленно начинает клясться, что женится на «мадмуазель Дэбе», ибо без неё попросту не может жить. Но теперь, когда между ним и Зоей устранены все недомолвки, каждый из них становится открытым полем внушения для другого: «В душу мою хлынуло счастье, и стал я благодарить Зою, а Зоя меня» [7, 2, с.155]. Произошло обратное расщепление тела и души. В любви иногда изменяет тело, в их нелюбви - душа. И замышляемый против родительской воли бунт не приводится в исполнение, ибо «это объяснение в нелюбви было счастливее любого любовного объяснения» [Там же]. Подталкивает их друг к другу и давление среды «этих шутов», где притворство стало нормой, а они благородно сказали друг другу правду. Их счастливый вид обманул родителей, и молодые всё-таки стали супругами. В некотором смысле обратную перспективу даёт рассказ «В рождественскую ночь». Молодая женщина с тревогой всматривается в море, которое вот-вот взломает лёд, и рыбаки, с которыми ушёл и её муж, могут не вернуться. И когда становится ясно, что лёд ломается, раздаётся её «смех, детский, счастливый». Он настолько не вяжется с общим горем собравшихся на берегу, что сразу же возникает предположение, что она «тронулась в уме-то» [7, 2, с. 289]. Смех женщины разрушает всеобщую суггестию горя и переводит её для всех остальных в разряд ненормальных людей. На самом же деле, утрата мужа - это освобождение и счастье для неё. Отстранившись от помощи, она сама поднимается по высокой лестнице. Но её «высокий, статный муж» вернулся. И он тоже смеётся от счастья, что «его ждали на этом холоде, в эту ночную пору! Это ли не любовь?» [7, 2, с. 290]. Этот смех, напротив, возвращает настоящее нормальное положение вещей. И тогда женщина отвечает воплем, в котором «слышалось всё: и замужество поневоле, и непреоборимая антипатия к мужу, и тоска одиночества, и наконец рухнувшая надежда на свободное вдовство» [Там же]. Вопль этот обращён к прошлому, и потрясённый муж понимает, что она ждала его гибели. Это приводит героя к затмению рассудка, спасительного смеха не последовало, а горе сделало его подвластным чужому внушению. Он решает дать женщине то, что она так страстно желала, и уплывает в море с дурачком Петрушей (важная деталь насмешка над серьёзностью решения мужа), желающим избавиться от мучительной боли. Тут только женщина понимает, что её любили по-настоящему, но её призыв вернуться прозвучал слишком поздно. В этом романтическом рассказе именно смех, служащий сбою в работе суггестии, играет положительную роль. И только смерть воистину серьёзна. Если в рассказе «0 том, как я в законный брак вступил» персонаж достигает счастья, ничего не понимая, но много говоря, то «В рождественской ночи» к непоправимой беде супругов приводит именно понимание, достигаемое путём внушения и почти без слов.

Столкновение внутреннего убеждения личности с давлением извне превосходно показан в рассказе «Дамы», где директор народных училищ, приняв справедливое решение помочь потерявшему голос учителю Временскому 
устроиться на место письмоводителя в приюте, вынужден изменить его под воздействием своей жены и жён высокопоставленных особ, симпатизирующих другому кандидату. С одной стороны, ни дамы, ни их записочки не имеют в его глазах никакого авторитета, но он надломлен их количеством. Наконец, он видит аттестацию Ползухина, подписанную самим губернатором, но и это тоже попадает в фильтр недоверия: «По всему видно было, что губернатор подписал не читая, лишь бы только отделаться от какой-нибудь навязчивой барыни» [7, 5, с. 107]. Это умноженное количество дам по их упрямству напоминает жену перечницу русского фольклора, предпочитающую переупрямить и мужа, и объективные обстоятельства. Когда же она утонула, муж пошёл искать ее тело не вниз, а вверх по течению,

Прохожие обзывают его дураком, но он объясняет ситуацию: «Она всё делала наперекор, так уж и теперь, верно, пошла против течения» [5, с. 212].

Можно сказать, что абсолютно не убеждаемая женщина скроила-таки мужа по своему образу и подобию. Он тоже не уступает здравому смыслу.

А директор он вынужден уступить не жене, не знакомой, а неизвестной «навязчивой барыни». Называя потом нового соискателя «шаркуном», «бабьим угодником», он, вероятно, понимает, что это относится и к нему, и к губернатору. Вместо того чтобы извиниться перед Временским, которому теперь он вынужден отказать, он именно ему адресует свой гнев, которого в большей мере заслуживает он сам. Логически получается, что повторение ложной информации возводит её в степень практической истины, которой, признавая всю её несправедливость, приходится следовать.

\section{Список литературы:}

1. Воронин В.С. Законы фантазии и абсурда в художественном тексте. Волгоград: Вол ГУ, 1999.

2. История эстетической мысли. Т.4. Вторая половина ХІХ века. М.: Искусство, 1987.

3. Поршнев Б.Ф. Контрсуггестия и история (элементарное социально-психологическое явление и его трансформация в развитии человечества) // История и психология: М.: Наука, 1971. С. 7-35.

4. Поршнев Б.Ф. Социальная психология и история. М.: Наука, 1979.

5. Русское народное поэтическое творчество. Хрестоматия. Л: Просвещение, 1987.

6. Сухих И.Н. Проблемы поэтики А.П. Чехова. Л.: ЛГУ, 1987.

7. Чехов А.П. Полн. собр. соч. и писем. М.: Наука, 1983-1986.

\section{References:}

1. Voronin V.S. Laws of fantasy and absurdity in a literary text. Volgograd: Vol State, 1999.

2. The history of aesthetic thought: In $6 t$. T.4. The second half of the XIX century. M.: Art, 1987.

3. Porshnev B.F. Kontrsuggestiya and history (basic socio-psychological phenomenon and its transformation in human development) // History and Psychology: M.: Science, 1971. Pp. 7-35.

4. Porshnev B.F. Social psychology and history. M.: Nauka, 1979.

5. Russian folk poetry. A: Education, 1987.

6. Suhih I.N. Problems of Poetics A.P. L.: Publishing Leningrad, 1987.

7. Anton Chekhov Full. cit. Op. and letters. M.: Science, 1983-1986.

(C) 2015, Воронин B.C.

Суггестия, контрсуггестия и законы фантазии в прозе А.П. Чехова
(C) 2015, Voronin V.S.

Suggestion, kontrsuggestion and laws of fantasy A.P. Chekhov's prose 


\title{
Голубева Ю.В. Номинация жестов английскими глаголами и глагольными сочетаниями, не обладающими системным значением жестикуляции
}

\author{
Golubeva Ju.V. \\ Nomination of gestures by English verbs and the verbal \\ combinations of different lexical categories
}

В статье продемонстрирована способность глаголов разных семантических групп (не жестовых глаголов) описывать жестикуляцию в определённом контексте, на функциональном уровне. Тем самым подтверждается положение когнитивной семантики о неопределённости, размытости границ лексических категорий Ключевые слова: лексическая категория, жестовые глаголы, когнитивная семантика, прототипический подход, лексическое значение

\section{Голубева Юлия Викторовна}

Кандидат филологических наук, доцент Национально-исследовательский университет Белгородский государственный университет г. Белгород, ул. Победы, 85

\begin{abstract}
In the article we show the capacity of verbs of different semantic groups (not verbs of gestures) to describe gesticulation in a certain context, at a functional level. Thus one of the basic statements of cognitive semantics about uncertain boundaries of lexical categories proves to be true
\end{abstract}

Key words: lexical category, verbs of gestures, cognitive semantics, prototypic approach, lexical meaning

\author{
Golubeva Julia Victorovna \\ Candidate of Philological Sciences, Associate \\ Professor \\ Belgorod national research university \\ Belgorod, Pobeda st., 85
}

Данная статья посвящена изучению семантики и особенностей функционирования глаголов и глагольных сочетаний, обозначающих жесты. Актуальность проведенного нами исследования определяется необходимостью изучения особенностей механизма формирования семантики жестовых глаголов и глагольных сочетаний в рамках когнитивного подхода к языковым явлениям, где значительную роль играет человеческий опыт, образующий основу знания. Когнитивная семантика рассматривает значение как ментальный феномен и исследует то, как опыт осмысления человеком окружающей действительности воплощается в значениях языковых выражений. Вслед за А.Н. Барановым и Д.О. Добровольским [1] в качестве исходных положений когнитивного подхода к описанию лингвистической семантики нами рассматриваются следующие постулаты: о примате когнитивного, о нерелевантности противопоставления лингвистического и экстралингвистического знания, о тенденции к экономии усилий, о множественности воплощения когнитивных структур в языке, о неоднородности плана содержания языкового выражения, о множественности 
семантического описания, о значимости нестандартных употреблений. С позиций когнитивного подхода к представлениям о природе и механизмах человеческого мышления, категории не являются «вместилищами» с четкими границами, так что та или иная сущность должна быть либо внутри вместилища, либо находиться вне его. Согласно когнитивному подходу категории организуются по прототипическому принципу и их границы являются размытыми. Положение о неопределенности границ категорий находит подтверждение в нашей работе, в которой на примерах, полученных методом сплошной выборки из произведений современной англоязычной художественной прозы, показано, что в состав лексической категории жестовых глаголов могут быть включены глаголы других семантических групп, приобретающих значение жестикуляции на функциональном уровне.

С точки зрения когнитивного подхода к семантике слова значения языковых единиц нужно искать в сфере когнитивных процессов. По мнению Р. Лангакера [5], в описание значения слова необходимо включать энциклопедическое знание, учитывать энциклопедическую концепцию семантики слов. Как известно, языковой знак состоит из означающего (в нашей работе это глагольные наименования жестов) и означаемого (то есть реально существующих жестов). А.В. Филиппов отмечает то, что в случаях переложения жестов словами наблюдается два слоя лексического значения: слой поверхностного лексического значения (обозначение моментов физического производства жеста) и слой глубинного значения (значения, свойственного жесту как прямому знаку) [2, с. 191]. Таким образом, значение жестикуляции составляют два основных признака: 1) телодвижение 2) семиотическое значение, закрепленное за этим движением. Выразить идею жестикуляции только своим лексическим значением способны лишь глаголы и глагольные сочетания, содержащие в своей семантической структуре сему 'телодвижение', а также одну или несколько символических сем, то есть лексические единицы с системным значением жестикуляции. В ходе проведенного исследования нам удалось установить, что на функциональном уровне, благодаря введению в состав предложениявысказывания модификаторов смысла (жестовой природы обозначаемого глаголом действия), жестикуляция может быть описана глаголами других семантических групп и неустойчивыми глагольными сочетаниями.

Перейдём к рассмотрению глагольных лексем, не имеющих в своих словарных дефинициях значения «жестикуляция», включающего, как нами указывалось ранее, сему 'телодвижение' и 'символические' семы. Эти глагольные лексемы способны обозначать понятие «жестикуляция» лишь в определенной речевой ситуации, при введении в состав предложения или, в некоторых случаях, в прилегающий контекст указателей жестовой природы обозначаемого глаголом действия. В тезаурусе Роже [8] (в разделе Indication в статье Gesticulate) помимо глаголов и глагольных сочетаний с системным значением жестикуляции, приведены некоторые глаголы других семантических групп и неустойчивые глагольные сочетания, способные обозначать жесты в определенном контексте. 
Глаголы и глагольные сочетания, обозначающие движения тела, головы, конечностей (например, saw the air, thumb, jog, poke, snap и др.), могут быть средствами обозначения жестов, если в предложении или прилегающем контексте выражена абстрактная идея, закрепленная за этими движениями.

Если в семантической структуре глагола содержится идея обозначения чего-либо, а в предложении описывается движение человеческого тела, с помощью которого данная идея передаётся партнёру по коммуникации, то этот глагол также может быть идентифицирован как жестовый. Значение жестикуляции у таких глаголов и неустойчивых глагольных сочетаний является контекстно обусловленным.

Средствами обозначения жестов, раскрывающих их семиотическое значение, на функциональном уровне выступают некоторые глаголы указания, например, глагол indicate. В словаре Oxford Advanced Learner's Dictionary of Current English OALDCE [4, c.440] indicate определяется как 'point to; point out; make known; be sign of; show the need of; state briefly'. В словарной дефиниции indicate не обозначено то, что идея указания доводится до партнера по коммуникации с помощью того или иного движения человеческого тела. Indicate приобретает значение жестикуляции, когда в состав предложения или в прилегающий контекст вводятся указатели того, что обозначаемая глаголом абстрактная идея доводится до партнера по коммуникации с помощью жеста. Например:

She threw her finished cigarette into the flames ... . The gesture indicated disgust and disbelief [3];

"They grow yonder." With his free hand he indicated the tall palisade called Plover Cliff about half-mile down the coast [3];

That clumsy shrug of her shoulders indicated that she didn't care [3].

В первом из приведенных выше примеров указателем жестовой природы действия, выраженного глаголом indicate, является введённое в предложение существительное gesture. Во втором и третьем примерах указан инструмент исполнения жеста словосочетаниями with his free hand и that clumsy shrug of her shoulders. То, что indicate во втором предложении обозначает указательный жест, делает очевидным и словосочетание the tall palisade called Plover Cliff.

Глаголом указания, способным обозначать жест на функциональном уровне, является также show. Например:

This friendly-goodbye sort of bow showed pleasure for he had company for dinner [3];

Sister St Joseph by the way she stood, by every small gesture and the intonation of her answers, had shown the deep submission in which she held herself; and Waddington, frivolous and impertinent, had shown by his tone that he was not quite at his ease [7, c.136].

В обоих предложениях глагол show употреблен в значении 'give evidence or proof of having or being' [4, c.809]. На то, что данная абстрактная идея доводится до партнёров по коммуникации посредством жестов, указывают словосочетания friendly-goodbye sort of bow (в первом примере), by the way she stood, by every small gesture (во втором примере). Эти словосочетания и являются мо- 
дификаторами смысла в данном случае. Таким образом, show приобретает значение жестикуляции.

Обозначать жест в определенных контекстуальных условиях способен также глагол указания signal. Например:

He signalled to a car, going along the dark, narrow street [3].

"Do we have any more time?" He glanced at his watch and, shaking his head, signalled we didn't [3].

В обоих примерах глагол signal выступает в значении 'make a signal or signals to'[4,c.814]. В первом предложении на жестовую природу обозначаемого глаголом signal действия указывает контекст, поскольку заставить автомобиль остановиться в описанной ситуации можно было только жестом. Во втором примере на жестовый характер действия, выраженного глаголом signal, указывает устойчивое глагольное сочетание shake one's head, обозначающее движение головы.

Средством вербализации жеста на функциональном уровне может выступать глагол sign. Глагол sign способен выступать номинатом жеста на функциональном уровне, приобретая значение жестикуляции при наличии в предложении или прилегающем контексте указателей того, что действие осуществляется посредством телодвижения. Например:

Corman's raised hand signed to his men he was ready to get started [3];

His hand, put on her arm, signed she had to be brave, she had to be prepared for the worst [3].

В приведенных примерах глагол sign употреблен в значении 'make known (to sb) an order or request by making signs'[4, c.813]. В словарной дефиниции отражена лишь идея обозначения (make known (to sb) an order or request). В данных примерах таким указателями жестовой природы обозначаемых глаголом sign действий выступает существительное hand, называющее инструмент исполнения жеста. Таким образом, в предложениях sign - жестовый глагол.

В качестве средства обозначения жестовых кинем на функциональном уровне могут выступать не только глаголы указания, но и глаголы других семантических групп при условии выражения в предложении или прилегающем контексте формы жеста или какого либо указания на то, что обозначаемая глаголом абстрактная идея доводится до восприятия партнера по коммуникации телодвижением. Например:

Other kids made 'tsk' noises and capping their hands to their heads expressed great frustration [3];

With a wave of his hand he dismissed the servant [3];

Kate's hand on my arm stopped me [3];

Crossed her arms across her chest, she refused to discuss the subject [3];

Gesturing, he directed me to drive into the churchyard [3];

Then suddenly she withdrew from the pressure of his arm, what revealed her irritation [3];

With a nod he silenced them both [3];

With a wave of her hand she let them in[3]; 
it off [3].

Lucy wanted to explain everything, but with a shake of his hand he just waved

Перейдём к рассмотрению лексических единиц, описывающих движения тела, которые преобретают значение жестикуляции, если в предложении или прилегающем контексте выражена абстрактная идея, закрепленная за этими движениями.

К таким лексическим единицам относятся, прежде всего, неустойчивые глагольные сочетания, под которыми нами понимаются глагольные сочетания, не зафиксированные в словарях в качестве средства обозначения жестов. Они создаются для обозначения жестов, не являющихся распространёнными, общепринятыми, типичными для людей той или иной культуры. Это могут быть некоторые индивидуальные жесты. Например:

They hammered down their instruments and stamped their feet in approval as applause [3].

Глагольное сочетание stamp one's foot обозначает жест в данном примере. Значение жестикуляции данное неустойчивое глагольное сочетание приобрело благодаря введению в предложение словосочетания in approval as applause, объясняющего семиотическое значение описанного жеста.

Leach clenched his fists in irritation. "You know damned well what I'm talking about" [3].

Неустойчивое глагольное сочетание clench one's fists обозначает жест в данном примере. Значение жестикуляции данное неустойчивое глагольное сочетание приобрело благодаря введению в предложение словосочетания in irritation, объясняющего семиотическое значение, закреплённое за данным жестом.

"You see what I'm saying?" "What's that?" Roman cupped a hand behind his ear to show he couldn't hear quite well [3].

Неустойчивое глагольное сочетание to cup a hand behind one's ear обозначает жест в приведенном примере. Значение жестикуляции данное неустойчивое глагольное сочетание приобрело благодаря введению в предложение придаточного дополнительного he couldn't hear quite well, объясняющего семиотическое значение, закреплённое за данным жестом.

"You remember what we talked about," his father said and patted Sean's shoulder in dismissal [6, c.8].

Неустойчивое глагольное сочетание patter one's shoulder обозначает в данном предложении жест. На языковом уровне семиотическое значение жеста выражено предложным сочетанием in dismissal. Это предложное сочетание и является указателем жестовой природы движения, обозначаемого глагольным сочетанием.

Whitey looked back over his shoulder as Sean approached, and shook his head, jerked his thumb at the assistant M.E.

"Souza," he called.

"Yeah?"

"Get some information to check the trial leading up here ..." [6, c.152]. 
В приведенном отрывке жест, обозначенный неустойчивым глагольным сочетанием to jerk one's thumb, используется с целью привлечь внимание собеседника, обратить внимание собеседника на что-либо. Сделать вывод о семиотическом значении жеста нам позволяет прилегающий контекст.

"There are many foolish people in the world and when a man in a rather high position puts on no frills, slaps them on the back, and tells he'll do anything in the world for them, they are very likely to think him clever [7].

В приведенном примере жест, обозначенный неустойчивым глагольным сочетанием to slap smb. on one's back, используется для выражения дружеского отношения, расположения к кому-либо. Сделать вывод о семиотическом значении жеста нам позволяет прилегающий контекст.

"I was angry when Mommy wouldn't let me have a cookie."

"Right"

"And I slammed the door and I didn't let her come in" [3].

В приведенном примере to slam the door обозначает жест, который используется для выражения отрицательных эмоций (а именно, раздражения, злости). Сделать вывод о семиотическом значении жеста нам позволяет прилегающий контекст, описывающий способы выражения ребёнком своего недовольства, обиды на мать.

She covered her face with her hands. "Oh, Mother, you make me ashamed" [7, c.161].

Глагольное сочетание cover one's face with one's hands обозначает жест, выводящий вовне эмоциональное состояние (стыд) героини произведения. Семиотическое значение жеста выражено в прилегающем контексте.

Once more I gave Kitty a long, searching, and sagacious look. Then she laid her hand gently on her arm.

"You know, my dear child, that one cannot find peace in work or in pleasure, in the world or in the convent, but only in one's soul" [7, c.150].

Неустойчивое глагольное сочетание to lay one's hand on one's arm обозначает в данном случае жест доброжелательного отношения, сочувствия и симпатии к собеседнику, на что указывает прилегающий контекст, описывающий задушевную беседу двух женщин.

Joyce kicked her under the table to make her stop laughing [3].

Неустойчивое глагольное сочетание to kick smb. under the table в данном примере обозначает жест, на что однозначно указывает описание семиотического значения, закреплённого за телодвижением, а именно - to make her stop laughing.

"Raise your hand if you have any questions" [3].

Неустойчивое глагольное сочетание to raise one's hand в данном предложении обозначает жест, на что указывает описание семиотического значения, закреплённого за телодвижением, а именно - you have any questions.

She clenched her hands, trying with all her might to control herself, for she saw two tears run slowly down his wasted cheeks [7, c.209];

She clenched her hands in order to prevent herself from telling him to hold his silly tongue. She was in black rage [3]. 
Глагольное сочетание to clench one's hands в данных примерах обозначает жесты, на что указывают введённые в состав предложений описания семиотического значения движения тела (сжимания рук в кулаки), а именно - trying with all her might to control herself (попытка подавить в себе проявление эмоций), in order to prevent herself from telling him to hold his silly tongue (попытка удержаться от оскорблений).

Список глагольных сочетаний, описывающих различные движения человеческого тела, которые на функциональном уровне могут приобретать значение «жестикуляция», может быть продолжен. Поскольку любое движение человеческого тела может быть идентифицировано как жест при условии закрепления за ним определенного семиотического значения, то и глагольная лексема, обозначающая соответствующее движение, может определяться как номинация жеста в определенном контексте, описывающем использование жестов в процессе коммуникации.

\section{Список литературы:}

1. Баранов А.Н., Добровольский Д.О. Постулаты когнитивной семантики // Известия АН. Сер. лит. и яз. 1997. T. 56. № 1. С. 11-21.

2. Филиппов А.В. Жесты и их отображение в тексте художественного произведения //

Лингвистический сборник. Моск. обл. пед. инс-т им. Крупской. М., 1975. Вып. 4. С. 185-194.

3. British National Corpus. URL: http://www.natcorp.ox.ac.Uk

4. Hornby A.S. Oxford Advanced Learner's Dictionary of Current English. Oxford: Oxford Univ. Press, 1974.

$1055 \mathrm{p}$.

5. Langacker R.W. Foundations of cognitive grammar. Stanford (Calif): Stanford Univ. Press, 1987. Vol. 1. 516 p.

6. Lehane D. Mystic River. N.Y.: Harper Torch, 2002. 478 p.

7. Maugham W.S. The Painted Veil. M.: Менеджер, 2000. 272 c.

8. Roget's Thesaurus. Longmans Green \& Co.: Penguin Books, 1978. 712 p.

(C) 2015, Голубева Ю.В.

Номинация жестов английскими глаголами и глагольными сочетаниями, не обладающими системным значением жестикуляции
(C) 2015, Golubeva Ju.V.

Nomination of gestures by English verbs and the verbal combinations of different lexical categories 


\title{
Ласкова М.В., Статова И.Ф. Особенности использования личного местоимения «Я» в английском и русском языках
}

\author{
Laskova M.V., Statova I.F. \\ The pecularities of personal pronoun „I" usage \\ in the English and Russian languages
}

Статья посвящена особенностям использования личного местоимения «Я» в английском и русском языках. Статья раскрывает насколько выражен индивидуализм в культуре Америки и России, а так же какие проблемы возникают перед переводчиками при работе с понятиями и терминами из области психологии

Ключевые слова: личное местоимение «Я», индивидуальность, психология, самокопание

\section{Ласкова Марина Васильевна}

Доктор филологических наук, заведующая кафедрой

Южный Федеральный Университет

2. Ростов-на-Дону, ул. Большая Садовая, 33

\section{Статова Инна Федоровна}

Студент

Южный Федеральный Университет

2. Ростов-на-Дону, ул. Большая Садовая, 33
The article is devoted to the pecularities of personal pronoun "I" usage in the English and Russian languages. The article shows what is the level of individualism expression in America and Russia, and what problems the translator can face when dealing with the terms concerning Psychology

Key words: personal pronoun «I», individualism, psychology, self-searching

Laskova Marina Vasilievna

Candidate of Philological Sciences, Hesd of

Department

Southern Federal University

Rostov-on-Don, Bolshaia Sadovaia st., 33

\section{Statova Inna Fedorovna}

Student

Southern Federal University

Rostov-on-Don, Bolshaia Sadovaia st., 33

The psychology glossary, terms referring to human mentality and to the word «I» have had a great impact on English language for decades. In the Soviet Union there was a proverb «There is no I in team» and in America at that time the motto of the human personality was «Me, Myself and I». Natural American individualism is brought up on the introspection and world view through their own «I». Zigmund Freud's ideology had the great influence on this.

In Russia the situation was quite different. As for more than half a century the wave of Freudianism, his follower's psychoanalytical jargon were ignored in the Soviet union, the Russian language often lacks the terms, that can convey the concepts of psychology. Though today there are calques from English (most often of Latin origin), the common mentality and the way of thinking remain different. Consequent- 
ly, it often causes a number of problems for translators to solve when dealing with English terms, the main meaning of which is obsession on self-searching $[2,75]$.

"If the 70s were dubbed the Me'decade, this era could well be a My Decade»the New York Times wrote.Young people of those times were called «the me generation». They were people who set their own needs above the needs of the society or any group, including a family. That mentality remained in 1990s when the culture of virtual communications and electronic ways of communication created its fashionable words, such as eTrade, eCommerce, eBay (the website of electronic actions for goods purchase and sale). Today American user's attention is focused on their «I» on the computer screen: e.g. «My computer», «My documents», «Mobile me».

People buy mobile phones through the company MyClick, have refreshing drink Mycoke, and chat with their friends on the popular website MySpace. Using the personal adjective in advertisement some commercial companies try to impart the aura of something personal and «sincere» to their products.

The cult of "I" is sometimes brought to extremes and logic distortion in the language. me».

e.g. «My dog Rosy was in the wedding. She wore a thistle collar. It was very

The speaker sees in her dog wearing that collar the reflection of her personality and character.

"I" has touched the human's mind not only through psychoanalysis. Within many years the most popular «hit» in America was the song «I will survive» of the popular singers Donna Summer and Gloria Gaynor. The words of the other song belong to the singer Johnny Carson: «I'll do it my way». Americans didn't forget Bush's philosophy: My way or the highway - «do the way I want or don't do at all». The former president's arrogant «I» revolted the newspaper «New York Times»:

e.g. «The president's hyperpartisanship and my way or the highway arrogance is now close to paralyzing his own administration».

However lately the favorite word «my» has lost its real meaning. It has been replaced by narratives and novels, containing a lot of fictitious stories about so-called «my experiences», written with only purpose - to earn the fortune for the author and publishing houses. When everybody found out that Monique De Wael's story about her sufferings during Holocaust is a forgery, she calmly replied: «The story is mine. It is not actually reality, but my reality, my way of surviving».

The person, who really thinks, that his subjective reality - my is objective reality is not an adequate person, but the one, being on verge of psychotic condition [1, 36].

In American conversations and media the expressions "a feel good or touchyfeely experience" and "I feel your pain" have become very common. Many TV programs show television series about feel-good, redemptive experiences - inspiring, emotional feelings that keep the audience in a good mood and make them feel satisfied, though the content of these series is just a fiction. And the audience, used to the art forgeries, badly distinguishes true to life stories from made-up ones. The main thing is that it enjoys superficial feelings, expressing on the screen.

e.g. «He referred to the touchy-feely television psychologist Phil McGraw...» 
e.g. «It's great to see this couple in such feel-good movies...»

The second «sincere» sympathy expression - I feel your pain (I sympathize, take your pain hard, and understand what you're going through with all my heart). For example, one of the former presidential candidate told the active worker of the campaign against AIDS: «I feel your pain, but if you want to attack me personally, go support someone else for president». These words meant «I'm sorry for you, but that's your problem and I'm not going to do a damn thing about it». But sympathy with reason or without it - refers to everybody without exception. A journalist wrote about the plans of the budget cuts on New-York public transport:

«This means less money in the system, which means everyone feels the pain».

Common phrases from the pop-psychology language also clearly show how «emotional words» lose their first meaning. «I've gotta do what I've gotta do» literally means: «I must do my duty». In the past the essence of this phrase was to ensure, that extremely harsh living conditions sometimes caused extreme reactions and incredible actions. In the war, concentration camp, after the earthquake people often appeared to be in the situations that needed inhuman efforts and courage. People sometimes even had to become deserters, betrayers and thiefs. However today «I've gotta do what I've gotta do» is more often used for self-justification of someone's egoistic and immoral behavior. That's why now it has a meaning «I'm afraid I have to do that despite of unpleasant consequences for the others»:

e.g. «I know I shouldn't badmouth John- he's my former colleague, and he's a friend. But I've gotta do what I've gotta do - I'm desperate about this job».

There is one more word, that has more than one meaning - inner. Today this word is overused, talking about the feelings in the meaning of something unconscious, hidden inside a person:

e.g. «Embrace your inner grouch. Optimism is not always the best solution».

Psychological field of the English language sets for a Russian translator two quite different problems. The first one appears when he deals with the words and expressions, reflecting rugged American individualism. The personality of a person, whose mentality is formed by the principle "me, myself and I" is characterized by overselfishness, so popular in Western countries. Besides, taking into account the difference of the Freud's influence on Americans and Russians, psychological terms are quite the same in both countries. So different modern dictionaries should be resorted to while analyzing terms connected with American psychology.

\section{Список литературы:}

1. Deckert, Sharon K. and Caroline H. Vikers. An Introduction to Sociolinguistics: Society and Identity. 2009.

2. Залевская А.А. Психолингвистические исследования. Слово. Текст: Избранные труды. М.: Гнозис, 2005.

(C) 2015, Ласкова М.В., Статова И.Ф. Особенности использования личного местоимения «Я» в английском и русском языках
(C) 2015, Laskova M.V., Statova I.F.

The pecularities of personal pronoun "I" usage in the English and Russian languages 


\title{
Голубева С.Л. Альтернативные системы интернет-коммуникаций
}

\author{
Golubeva S.L. \\ Alternative Internet communication systems
}

В статье анализируется влияние инновационных альтернативных систем интернет-коммуникаций на социокультурные процессы в современном обществе

Ключевые слова: Интернет, инновации, коммуникации, технологии

\section{Голубева Светлана Леонидовна}

Старший преподаватель

Санкт-Петербургский государственный институт кино и телевидения

Санкт-Петербург, ул. Правды, 13
The article analyzes the influence of innovative Internet communication systems on sociocultural processes in the modern society

Key words: Internet, innovation, communication, technology

\section{Golubeva Svetlana Leonidovna}

Senior Teacher

Saint-Petersburg institute of film and television

Saint-Petersburg, Pravdy st., 13

Возможности человека ограничены только его воображением Чарльз Кеттеринг (Charles Kettering) [1]

Разработка и постоянное усовершенствование инновационных технологий обогащают нашу жизнь новым опытом, идеями и возможностями, вселяя надежду, что каждый следующий день будет лучше предыдущего. «Если это так, то зачем ждать?» спрашивает «Куалко́м» (Qualcomm) - компания по разработке и исследованию беспроводных средств связи, предлагая различные девайсы с неограниченными возможностями: от эффективного использования ресурсов и оптимизации транспортной системы до непрерывного контроля жизнедеятельности организма, обеспечения личной безопасности и неограниченного доступа к информации. Единственным условием является подключение к Интернету, при этом, увеличивается количество гаджетов из серии «носимая электроника». Так, например, на ежегодной выставке IT-достижений CES 2015 (Consumer Electronics Show) китайская компания Estar Technology Group Со представила первый в мире «голографический» смартфон Takee1, создающий на дисплее стереоскопический эффект без 3D-очков и управляющий изображением бесконтактным способом; компания Google разрабатывает для диабетиков «умные» линзы, которые не только восстанавливают нормальную рефракцию глаза, но и измеряют уровень глюкозы в крови, а будущие наноробо- 
ты смогут автономно контролировать артериальное давление и осуществлять анализ крови [2].

Исследователь берлинского технологического центра (Design Research Lab) Tом Биллинг разработал специальную перчатку со встроенными сенсорными датчиками давления, способную переводить тактильный контакт с алфавитом для слепоглухонемых (азбука Лорма) в электронный текст и обратно. Перчатка Биллинга снимает ограничения общения для людей с заболеваниями зрения и слуха, основанного исключительно на физическом тактильном контакте, действуя как переводчик и открывая доступ на широкие просторы интернет-коммуникаций, имеющих преимущественно текстовую основу. По мнению Биллинга, современное общество принимает невероятные возможности электронных коммуникаций как должное. Для людей, физически неспособных воспринимать визуальные и звуковые сигналы, пространство интернеткоммуникаций продолжительное время оставалось недоступным; теперь, с перчаткой для азбуки Лорма, у них, в буквальном смысле, весь мир на ладони [3].

Расширению круга общения людей, ограниченных (по той или иной причине) в передвижении, способствуют различные интернет-проекты в области культуры, туризма и развлечений. Многие музеи используют приложения Web 2.0 и Web 3D (специальные сайты систем сетевого взаимодействия), в основе которых лежит принцип коммуникаций и равноправного участия [4].

Несмотря на опасения музейных работников, что с появлением цифрового артефакта исчезает ценность оригинала, «электронные музеи уже становятся и будут дальше становиться все более распространенным явлением в электронных сетях и, по мере их развития, посетители и пользователи будут осознавать богатство коллекций, даже если эти коллекции находятся за пределами самих музеев» [5, С. 17].

Так, например, благодаря виртуальному проекту Гугл - Art Project (виртуальные музеи мира), где представлено около 20 всемирно известных музеев, включая Эрмитаж и Третьяковскую галерею, каждый, кто имеет доступ в интернет, может совершить прогулку по залам музея и насладиться произведениями искусства в прекрасном качестве в формате 3D. Картографические сервисы Google maps (функция «Street view») и Яндекс-карты (функция «Панорама улиц»), породившие интернет-термин «неогеография» (новая интерактивная география), позволяют виртуально прогуляться по улицам городов мира, а проект AirPano предоставляет возможность оказаться в любой точке земного шара на высоте птичьего полёта. Современный уровень компьютерной графики делает возможным создавать игры с полноценным трёхмерным виртуальным миром, по которому можно путешествовать, пользуясь различными видами транспорта, а онлайн игра Second Life позволяет общаться с другими людьми и заниматься бизнесом. C программой Google Планета Земля становится доступным виртуальное путешествие под водой, а программа Stellarium предлагает путешествие по космосу.

Несмотря на улучшение качества жизни за счёт инновационных технологий, нельзя забывать, что по мере их развития возрастает ответственность об- 
щества. Согласно социологическим исследованиям, доступность практически любой информации в Интернете развивает ложное самомнение: пользователи ПК переоценивают свою образованность и умственные способности. Американская ассоциация психологов (American Psychological Association) провела исследование, в ходе которого испытуемым, разделённым на две группы, задавали одинаковые вопросы, причём, одна группа могла воспользоваться Интернетом, другой давались готовые ответы в форме множественного выбора. Те участники эксперимента, которые искали ответы во всемирной сети, оценивали свои знания по данной теме гораздо выше фактического уровня, даже, если не находили правильного ответа. По мнению Мэтью Фишера, учёного - психолога из Йельского университета, люди, имея постоянный неограниченный доступ к информации, начинают ассоциировать знания, полученные из глобальной сети со своими личными познаниями. Фишер утверждает, что такая необъективная оценка своего интеллектуального и профессионального уровня может иметь негативные последствия [6].

Многие оптимистически настроенные учёные полагают, что новые технологии, независимо от того, будет ли это Интернет, или последняя модель телефона, способны трансформировать общество. Американский социолог Харви Сакс (Harvey Sacks) утверждает, что не только люди, связанные с наукой возлагают свои надежды на изобретение некоего фантастического средства коммуникации, которое способно изменить мир. Согласно Саксу, самые гениальные изобретения человечества всегда приспосабливались и встраивались в уже существующий мировой порядок. По его мнению, любое новое устройство, прежде всего, «даёт нам шанс по-новому взглянуть на окружающую действительность, а целью тех, кто пишет об инновационных технологиях должно стать не просто описание усовершенствованного девайса, а возникающая с его появлением возможность более тщательно изучить самих себя» [3].

Британский писатель, теоретик в области инновационных технологий Том Чатфилд (Tom Chatfield) сравнивает развитие технологии с мифической серебряной пулей, которая способна изменить многое, предостерегая, что её можно поместить и в оружие, пусть, даже, напечатанное на 3D принтере [7].

В заключение необходимо подчеркнуть: никто не может точно сказать, будут ли инновационные системы интернет-коммуникаций иметь позитивные или негативные последствия. Однако, рецепт обращения любого научного открытия во благо известен; нужно всегда следовать морально-этическим нормам и принципам, давно выработанным человечеством.

\section{Список литературы:}

1. Charles Kettering. Quotes.

ULR: http://www.brainyquote.com/quotes/authors/c/charles_kettering.html

2. Softmixer. Сетевой журнал.

ULR: http://www.softmixer.com/2015/01/ces-2015.html?m=0

3. BBC Future.

ULR: http://www.bbc.com/future/story/20150312-how-to-talk-online-with-only-touch

4. Вильямс книга Web 2.0: создание приложений на РНP.

ULR: http://www.williamspublishing.com /Books/978-5-8459-1590-0.html 
à 5. Взаимодействие веб-сайтов по культуре с пользователем. Рекомендации. MINERVA EC Project, 2008. 201c.

6. Разум и мозг: Интернет журнал психиатрии.

ULR: http://mindbrain.ru/2015/04/01/3163.html

7. Afflictor. ULR: http://afflictor.com/tag/tom-chatfield/

(С) 2015, Голубева С.Л.

Альтернативные системы интернет-

коммуникаций
(C) 2015, Golubeva S.L.

Alternative Internet communication systems 


\title{
Савельева Д.А., Герасимова А.И, Ярмухаметов И.В. Культурная идентичность. Эмпатия и симпатия как призма восприятия родной и чужой культуры
}

\author{
Savelieva D.A., Gerasimova A.I., Yarmukhametov I.V. \\ Cultural identity. Empathy and sympathy as a prism \\ of perception of native and foreign culture
}

В статье характеризуется культурная идентичность. На основе собственного опыта проводится разграничение восприятия родной и чужой культуры с позищии симпатии и эмпатии Ключевые слова: культура, культурная идентичность, эмпатия, симпатия

\section{Савельева Дарья Александровна}

Студент

Стерлитамакский филиал Башкирского государственного университета

Республика Башкортостан, г. Стерлитамак, пр. Ленина, 49

\section{Герасимова Анжелика Игоревна}

Студент

Стерлитамакский филиал Башкирского

государственного университета

Республика Башкортостан, г. Стерлитамак, пр. Ленина, д. 49

\section{Ярмухаметов Ильнур Валиянович Студент \\ Стерлитамакский филиал Башкирского государственного университета Республика Башкортостан, г. Стерлитамак, пр. Ленина, д. 49}

In article cultural identity is characterized. On the basis of own experience differentiation of perception of native and foreign culture from a position of sympathy and empathy is carried out Key words: culture, cultural identity, empathy, sympathy

\author{
Savelieva Daria Aleksandrovna \\ Student \\ Sterlitamak branch of Bashkir state university \\ Sterlitamak, Lenin Avenue, 49
}

\author{
Gerasimova Anzhelika Igorevna \\ Student \\ Sterlitamak branch of Bashkir state university \\ Sterlitamak, Lenin Avenue, 49
}

\author{
Yarmukhametov Ilnur Valiyanovich \\ Student \\ Sterlitamak branch of Bashkir state university \\ Sterlitamak, Lenin Avenue, 49
}

Век информатизации обострил проблему, связанную с культурной идентичностью, которая сегодня рассматривается учеными разных специальностей политологами, социологами, философами, психологами, и активно обсуждается в обществе. Идентичность можно рассматривать как некую устойчивость национальных, цивилизационных и социокультурных параметров, в их основе заложены ответы на вопросы «кто я?» и «кто мы?». Проблема идентичности в современном мире включает, прежде всего, персональную или личностную 
идентичность, когда у человека сформировано устойчивое представление о самом себе как о члене общества. Персональная идентичность вызывает у личности ощущение отождествления со своим народом, позволяющее ему определить свое место во множестве культур.

В документах всемирной организации ЮНЕСКО культурная идентичность понимается как «жизненное ядро культуры, тот динамический принцип, через который общество, опираясь на свое прошлое, черпая силу в своих внетренних возможностях и осваивая внешние достижения, отвечающие его потребностям, осуществляет процесс постоянного развития» [4, с. 110].

Необходимо подчеркнуть, что идентичность предполагает осознание человеком и общностью людей своего реального места в природном и социальном мире, проведение границы между «своим»и «чужим», определение круга лиц, с которыми индивид связан и сознательно отождествляет себя, и круга лиц, которому он реально противостоит. Наибольшее значение в процессе формирования идентичности имеют именно культурно-психологические моменты, поскольку идентичность - это, прежде всего, осознание личностью своей принадлежности к некоторому целому, дискурс собственной легитимации в пространстве символического универсума культуры. Необходимыми условиями формирования идентичности являются усвоение ценностей и норм определенной («своей») социокультурной общности, что, в свою очередь, возможно лишь на основе их противопоставления иной («чужой») нормативноценностной системе, а также наличие у человека четкого представления о самой окружающей действительности, позволяющего найти свое место в ней. Однако в условиях глобализации это оказывается чрезвычайно затруднительным [5, с. 303].

Важно подчеркнуть, что, с одной стороны, глобализация представляет собой объективный процесс формирования и последующего развития единого общемирового финансово-экономического пространства на базе новых, преимущественно компьютерных технологий [2, с. 51]. В связи с этим социологи связывают ее с процессом «размывания» национальных и культурных отличий между странами. Но в процессе глобализации размываются ценности различных культур, разрушаются традиции, обряды и ценности поколений.

«Идентификация», обозначающая отождествление себя с другим, выражает установленный эмпирический факт, что одним из самых простых способов понимания другого человека является уподобление себя ему. Это, разумеется, не единственный способ, но в реальных ситуациях взаимодействия люди часто пользуются таким приемом, когда предположение о внутреннем состоянии партнера строится на основе попытки поставить себя на его место. В этом плане идентификация выступает в качестве одного из механизмов познания и понимания другого человека. Существует много экспериментальных исследований процесса идентификации и выяснения его роли в процессе общения. В частности, установлена тесная связь между идентификацией и эмпатией. «Описательно эмпатия также определяется как особый способ понимания другого человека. Только здесь имеется в виду не рациональное осмысление проблем другого человека, a, скорее, стремление эмоционально откликнуться на 
его проблемы. Эмпатия противостоит пониманию в строгом смысле этого слова, термин используется в данном случае лишь метафорически: эмпатия есть аффективное "понимание". Эмоциональная ее природа проявляется как раз в том, что ситуация другого человека, партнера по общению, не столько "продумывается", сколько "прочувствуется"» [1].

Для культурной идентичности актуальны понятия симпатия и антипатия. Эмпатия в различных источниках психологии понимается по-разному. В научных журналах она характеризуется как «способность разделять переживания другого посредством ослабления границ собственного «я»», «психологическая близость, доверие» [3, с. 185]. В таком контексте симпатия показывает вовлеченность одного человека в дела и переживания другого. Так же симпатию можно рассмотреть как вовлечение в процесс восприятие самого себя, и это является точкой пониманию того, что могут чувствовать другие, это попытка примерить на себя переживания других. Поставить себя на их место и понять, что мы могли бы сделать на их месте.

Основным принципом эмпатии, по мнению европейского ученого М. Беннета, является способность идентификации с другой личностью. Некоторые из западных методистов, в отличие от М. Беннета, считают, что «степень идентификации является, возможно, менее важной, чем уровень эмоциональной вовлеченности и/или одобрения». Такой подход к пониманию эмпатии представляется нам противоречивым, ибо предполагает эмоциональную вовлеченность при сохранении собственных позиций, т. е. психологическое явление, которое мы идентифицируем с симпатией. При эмпатическом общении представления о собственной личности (собственном «я») и представления о личности другого (уже не «чужого», а просто другого) функционируют в восприятии каждого участника общения как равноправные взаимосвязанные представления о деятельности двух равноценных, но различных представителей разных культур. Другими словами, «симпатия» базируется на сходстве людей, «эмпатия» - на различиях. Эмпатия учитывает общие цели (создания единого значения) и общий контекст, т. е. ситуацию, в которой находятся. «При эмпатии некто вникает в чувства другого, при симпатии некто вникает в страдания (или радости) другого, но чувства (по этому поводу) остаются собственными». Различия между симпатией и эмпатией не затрагивают ни природы объекта отношения, ни степени вовлеченности в переживания, они касаются только принимаемой индивидом перспективы, только того, исходит ли он из собственной перспективы (симпатия) или способен принять альтернативную (эмпатия) [3, с. 184].

Симпатия - это наиболее распространенная реакция на переживания или положение собеседника. На основе симпатии и эмпатии формируется и толерантность к другим культурам. Человек начинает смотреть на ситуацию через себя и свои ощущения. С помощью этих чувств становится намного проще понимать других, человек начинает сравнивать и на основе сравнений делает для себя выводы, что ему больше дороже и что он хотел бы изменить для улучшения своего мировосприятия и культуры, в которой он живет, и в которой его воспитали. 


\section{Список литературы:}

1. Андреева Г.М. Социальная психология. Глава 7. Общение как восприятие людьми друг друга (перщептивная сторона общения).

URL: http://psylib.org.ua/books/andrg01/txt07.htm\#1

2. Делягин М.Г. Мировой кризис. Общая теория глобализации. М., 2003.

3. Елизарова Г.В. Культура и обучение иностранным языкам. СПб.: Издательство КАРО, 2005.

4. Ерасов Б.С. Сравнительное изучение цивилизаций.

URL: http://www.gumer.info/bibliotek_Buks/History/Eras/42.php

5. Лысак И.В. Проблема сохранения культурной идентичности в условиях глобализации // Философия в Беларуси и перспективы мировой интеллектуальной культуры. НАН Беларуси, Ин-т философии.

Минск: Право и экономика, 2011. С. 303-304.

(С) 2015, Савельева Д.А., Герасимова А.И, Ярмухаметов И.В.

Культурная идентичность. Эмпатия и симпатия как призма восприятия родной и чужой культуры
(C) 2015, Savelieva D.A., Gerasimova A.I., Yarmukhametov I.V.

Cultural identity. Empathy and sympathy as a prism of perception of native and foreign culture 